UNIVERSIDADE DE SÃO PAULO

FACULDADE DE FILOSOFIA, LETRAS E CIÊNCIAS HUMANAS DEPARTAMENTO DE CIÊNCIA POLÍTICA PROGRAMA DE PÓS-GRADUAÇÃO DE CIÊNCIA POLÍTICA

MONIKA DOWBOR

A arte da institucionalização: estratégias de mobilização dos sanitaristas (1974-2006)

(Versão revisada)

São Paulo 
MONIKA DOWBOR

\section{A arte da institucionalização: estratégias de mobilização dos sanitaristas (1974-2006)}

Tese apresentada ao Departamento de Ciência Política da Faculdade de Filosofia, Letras e Ciências Humanas da Universidade de São Paulo para a obtenção de título de Doutor em Ciência Política

Orientador: Profo Dro Adrian Gurza Lavalle

São Paulo 


\title{
A arte da institucionalização: estratégias de mobilização dos sanitaristas (1974-2006)
}

\author{
Tese apresentada ao Departamento de Ciência Política da \\ Faculdade de Filosofia, Letras e Ciências Humanas da \\ Universidade de São Paulo para a obtenção de título de Doutor \\ em Ciência Política sob a orientação do Profo Dro Adrian Gurza \\ Lavalle
}

Aprovado em

Banca Examinadora

Prof ${ }^{\circ}$ Dro Adrian Gurza Lavalle (orientador)

Profo Dro Eduardo Cesar Marques (membro)

Profo Dro Marcelo Kunrath Silva (membro)

Profo ${ }^{\circ}{ }^{\circ}$ Marcos Chor Maio (membro)

Profo ${ }^{\circ{ }^{\circ}}$ Rogério Arantes (membro)

Profa Dra Angela Alonso (suplente)

Prof $^{\circ}$ Dro Cicero Araujo (suplente)

Profa Dra Ligia Helena Hahn Lüchaman (suplente)

Profa Dra Vera Vera Schattan P. Coelho (suplente) 
Para Helio e Rafaela, queridos e sempre presentes 


\section{AGRADECIMENTOS}

Ao professor Adrian Gurza Lavalle, pelo processo da orientação que começou antes do doutorado e sempre foi marcado pela sua generosidade, pela sua paixão pela ciência, pela escuta atenta da minha fala e pela leituras exigentes da minha escrita, devolvidas sempre na forma de uma maior compreensão do mundo. Pela sua postura de diálogo incansável.

Ao professor Peter Houtzager, pela oportunidade de participar de uma pesquisa internacional, da qual se originou este trabalho, por ter me incentivado a acreditar nas minhas intuições analíticas, pelas deliciosas divagações teóricas em cafés de Brighton, Boston e São Paulo, e não menos importantes devoluções sobre meu trabalho.

Aos professores Luciana Tatagiba e Eduardo Marques, pela leitura atenta e pela disposição para pensar junto comigo sobre os possíveis caminhos no exame de qualificação. À professora Judith Tendler por compartilhar comigo suas experiências sobre os caminhos de pesquisa. Aos professores Hal Colebath, Marcelo Kunrath Silva e Pedro Jacobi, pelos comentários a versões e partes deste trabalho. Aos sanitaristas e professores, Gilson Carvalho e Laura C.M. Feuerwerker, pela leitura atenciosa das partes desta tese. Aos professores do Departamento da Ciência Política, pelos espaços de aprendizagem proporcionados nos cursos.

A todos os sanitaristas entrevistados, pela disposição e paixão de compartilhar seu conhecimento e experiência comigo.

Aos amigos e colegas do Núcleo de Democracia e Ação Coletiva do Cebrap, Euzeneia Nascimento, Hellen Guicheney, Jessica Voigt, Julia Amâncio, Liza Serafim, Maira Rodrigues, Maria do Carmo Albuquerque, Osmany Porto de Oliveira, Thiago Greghi, Wagner Romão, Ze Szwako, pelos debates sistemáticos, densos e calorosos que alimentaram muito meu processo de reflexão.

Ao Cebrap, pelo espaço de trocas que proporciona, e aos colegas desta instituição, Alexandre Barbosa, Danilo Torrini, Lara Mesquita, Maurício Fiori, Rogerio Barbosa, Samuel Moura e Victor Callil, pelo apoio. 
À Capes, pela da bolsa do doutorado.

Ao Institute of Develpoment Studies e ao Centre for the Future State e seu diretor, Mick Moore, pela oportunidade de participar da pesquisa "A reforma de serviços públicos: o papel da ação coletiva e da accountability social (Delhi e São Paulo)", da qual se originou este doutorado.

Ao departamento da Secretaria de Gestão Estratégica e Participativa do Ministério da Saúde por ter disponibilizado o acesso às entrevistas do projeto "A construção do SUS. História da Reforma Sanitária e do Processo Participativo". A Nathalia Boanova, pela ajuda no levantamento bibliográfico e nas pesquisas de fontes.

Aos funcionários da Secretaria do Departamento de Ciência Política da USP, Ana Maria, Rai, Wasne, pela postura profissional e, ao mesmo tempo, acolhedora.

Aos meus amigos de longa data, pelos diversos papeis que desempenharam, todos importantes e estruturadores da vida cotidiana de uma doutoranda, e pela presença na reta final: a Mércia, amigona, pela presença constante e pela ajuda concreta e tão útil; a Lu querida, e a Carlinhos, pelo respiro do tradicional almoço da quarta-feira e pela torcida; a Patoli, pela postura estimuladora e desafiadora, a Fabi pelas risadas da passageira do mesmo trem; a Encá, pelo carinho e preocupação; a Catherine pelo bom humor. A Monica e Malgosia, primas queridas que, com o senso de humor polaco-europeu, me faziam rir e cair na vida real.

À minha família polonesa, aquela de sangue, Krystyna, Tom e Wojtek, e àquela de laços de afinidade, Ania, Ewa, Misia e Piotr, pela torcida e compreensão. Ao Lalau, pelo abrigo nas últimas horas, nutrido pelas delícias do "café do tio Lalau".

Ao meu pai, kochany Tato, sempre materno e sempre presente nos dias de aperto.

Ao Tobi, companheiro de montão.

A duas pessoas que mais amo nesse mundo e que preenchem de sentido minha vida - de vocês parto; a vocês volto. Helio, meu marido, Rafaela, minha filha, obrigada pela paciência, suporte, amor, carinho, compreensão (e pelos cafezinhos, Rafi). Como diz Rafaela: amo vocês até a Lua. 


\section{DEGRAUS \\ Hermann Hesse}

Como toda flor definha e toda juventude desvanece, assim a vida a cada passo: assim nosso domínio da verdade e toda virtude florescem em seu tempo e não devem durar. Se a vida pode nos convocar a qualquer tempo esteja pronto para partir, coração, novo empenhar: esteja pronto bravamente e sem pesar para descobrir o novo brilho que velhos laços ofuscam. A cada começo uma força mágica faz morada a nos proteger e manter a vida alimentada.

Serenamente nos movemos, de distância em distância, sem que nos prenda o sentimento de lar.

O Espírito Cósmico não busca nos atracar mas içar âncoras em todo pouso:

pois mal aportamos da vida a extensão, fazemos do cais uma pátria, e inicia a lassidão.

Pois só aquele que se prepara para o risco da viagem pode evitar no hábito a ancoragem.

A hora de nossa morte pode nos enviar velozmente a frescos planos a vida a nos convocar a novos oceanos. Assim seja, coração: dê adeus sem cessar.

\section{(Tradução de Fabiana Jardim)}




\section{RESUMO}

Esta tese argumenta que a Teoria dos Movimentos Sociais - com o foco nos protestos como a forma de atuação dos movimentos e com a conceituação restrita da institucionalização - mostra-se insuficiente para dar conta dos movimentos sociais que atuam nas instituições políticas. Esta constatação partiu da observação do Movimento Sanitário/pela Reforma Sanitária, que tem se mobilizado, desde os anos 1970, em prol da defesa do acesso universal à saúde no Brasil. A reconstituição da sua trajetória nacional e do seu repertório de ação abrangeu o período entre 1974 a 2006, conduzida por meio de um estudo de caso. Foram analisadas suas transformações e permanências em termos dos diagnósticos e prognósticos, dos atores e dos eventos, bem como das formas de ação. O caso do Movimento Sanitário pela Reforma Sanitária mostra que movimentos sociais podem atuar via instituições, sem deixar de sê-los, e que, nessa atuação, seus atores recorrem aos elementos inovadores que colocam as autoridades diante de situações novas e aumentam a capacidade de mobilização do movimento.

Palavras-chave: movimentos sociais, Movimento pela Reforma Sanitária, Movimento Sanitário, repertório de ação dos movimentos sociais, setor de saúde 


\begin{abstract}
This thesis argues that the Theory of Social Movements which focuses on protests as the expression of movements' actions proves to be insufficient to account for the social movements that operate in political institutions. This finding was based on the observation of the Sanitarista Movement, which has been engaged since the 1970s in defense of universal access to health care in Brazil. The case study covers the reconstitution of the movement's national trajectory and repertoire of action from 1974 to 2006. We analyze its continuities and transformations in terms of diagnosis and prognosis, the actors and the events, and the forms of action. The case of the Sanitarista Movement shows that social movements do not cease to exist while acting in institutions and that in their institutional repertoire they are able to introduce innovative elements that put the authorities before new situations and increase the social movement capacity to mobilize.
\end{abstract}

Key words: public health sector, social movements, social movement repertoire, Sanitarista movement 


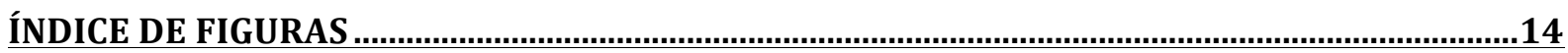

ÍNDICE DE SIGLAS...........................................................................................................15

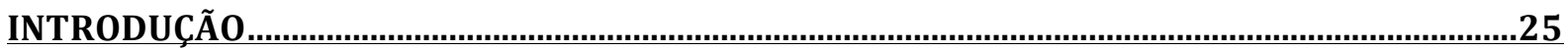

1. EM BUSCA DO ELO PERDIDO: ENTRE A TEORIA DOS MOVIMENTOS SOCIAIS E AS

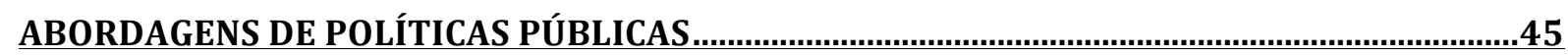

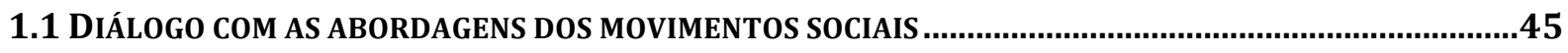

1.2 Categorias de atores nas ABordagens de Políticas PúbliCaS ..............................................69

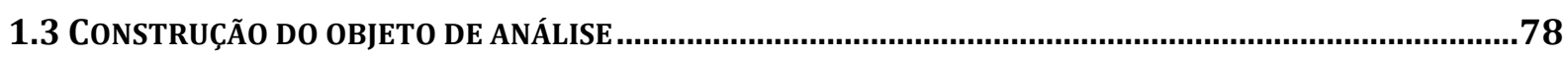

2. ENTRE AS SALAS DE AULA E OS GABINETES NO PODER EXECUTIVO: MOVIMENTO

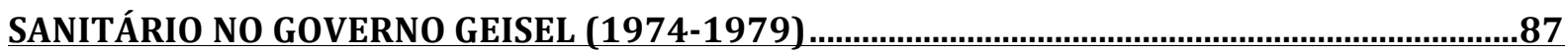

2.1 CONJUNTURA: GOVERNO DESENVOLVIMENTISTA, EXPANSÃO DAS POLÍTICAS SOCIAIS E INVESTIMENTO

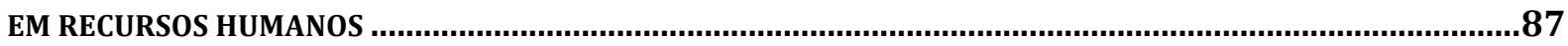

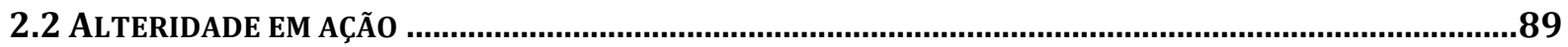

2.2.1 DiagNóSTICO E PROGNÓSTICO DO MOVIMENTO SANITÁRIO: SAÚDE E DEMOCRACIA................................... 90

2.2.2 EVENTOS E ATORES DO MOVIMENTO SANITÁRIO ………………………………...................................... 93

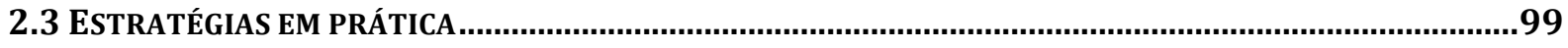

2.3.1 ESTRATÉGIA DO CAMINHO INSTITUCIONAL .......................................................................................99

2.3.1.1 Tática de atuação em programas e ações com perfil reformista ..............................................103

2.3.1.2 No coração do sistema (inimigo): tática de ocupação de cargos no nível federal..............108

2.3.1.4 Ocupar o vazio: tática de ocupação de cargos nas secretarias municipais de saúde........113

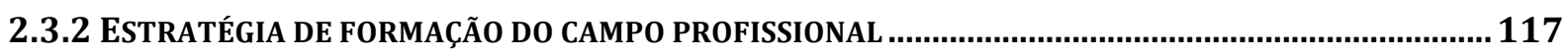

2.3.2.1 Tática de apropriação de espaços e atividades públicas..........................................................118

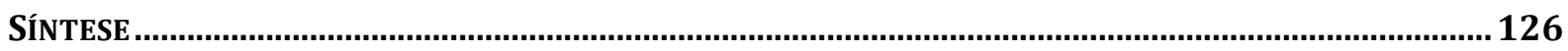

3. GABINETES DO PODER EXECUTIVO, CORREDORES DO LEGISLATIVO E O GINÁSIO DE ESPORTES DE BRASÍLIA: MOVIMENTO SANITÁRIO NA TRANSIÇÃO DEMOCRÁTICA (1984-

1989)

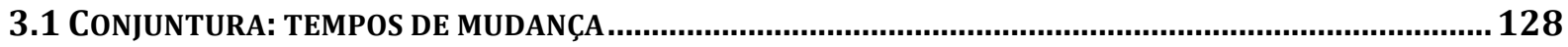

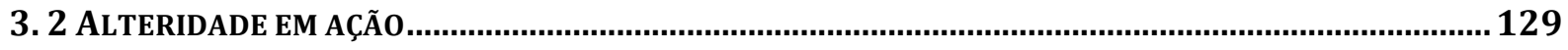

3.2.1 DiagnóSTICO E PROGNÓSTICO DO MOVIMENTO SANITÁRIO: A CONTROVERSA TESE DA ESTATIZAÇÃO.129 


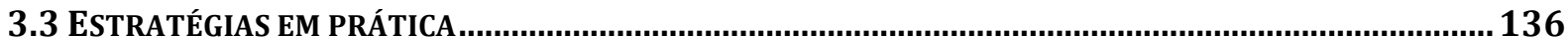

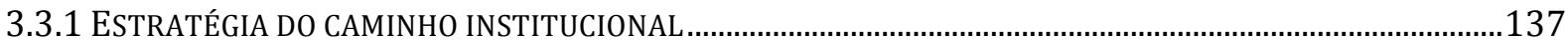

3.3.1.1 Nos gabinetes do poder executivo: tática de ocupação de cargos no nível federal ............137

3.3.2.2 Mobilização no Ginásio de Brasília: 8a Conferência Nacional de Saúde: ................................144

3.3.2.3 A Plenária Nacional de Saúde: lobby parlamentar do movimento sanitário........................148

3.3.2.4 O Conasems: ocupação de cargos, eventos e organização de representação política .......154

SÍNTESE.

\section{GUARDIÕES DA LEI: MOVIMENTO PELA REFORMA SANITÁRIA NO GOVERNO COLLOR}

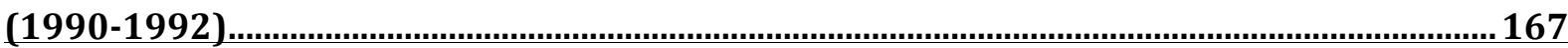

4.1 CONJUNTURA: REDEMOCRATIZAÇÃo, REGULAMENTAÇÃo DA CONSTITUIÇÃo E INSTABILIDADE....... 167

4.2 ALTERIDADE EM AÇÃO

4.2.1 Diagnóstico e PROGNÓSTiCo DO MOVIMENTO PELA REFORMA SANITÁRIA: INIMIGOS DO GOVERNO E GUARDIÕES DA LEI CONSTITUCIONAL

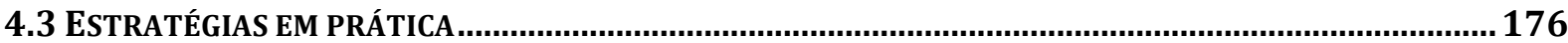

4.3.1 ESTRATÉGIA DE FORMAÇÃO DO CAMPO PROFISSIONAL …………………………...................................177

4.3.1.2 O Projeto Larga Escala: formação para a Reforma Sanitária nos interstícios dos setores de

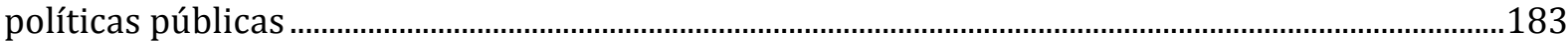

4.3.1.3 Os Núcleos de Saúde Coletiva: nas margens das universidades ..............................................186

4.3.1.4 Ordenar não é controlar: credenciamento dos cursos de saúde do nível superior ............190

4.3.2 ESTRATÉGIA DO CAMINHO INSTITUCIONAL

4.3.2.1 0 processo da aprovação da Lei Orgânica de Saúde no governo Collor: táticas "fora das instituições"

4.3.2.2 Escapando das contingências: o Conasems e os seus pontos de acesso e influência ao Estado

SÍNTESE.

5. MOVIMENTO PELA REFORMA SANITÁRIA NO GOVERNO FHC (1995-1998)

5.1 CONJUNTURA: ESTABILIDADE MONETÁRIA, AJUSTE FISCAL E IMPLEMENTAÇÃO DE POLÍTICAS PÚBLICAS

5.2 ALTERIDADE EM AÇÃo 203

5.2.1 Diagnóstico E PROGNÓSTICO do MOVIMENTO PELA REFORMA SANITÁRIA: “ERA NEOLIBERAL”.........203

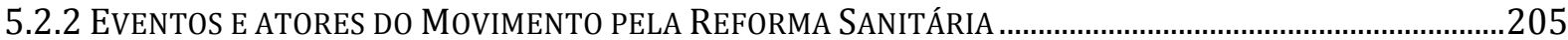

5. 3 ESTRATÉGIAS EM PRÁTICA 
5.3.1.1 Estado contra Estado: tática de accountability horizontal .......................................................209

5.3.1.2 A Plenária Nacional dos Conselhos da Saúde: ator-evento ......................................................215

5.3.2 ESTRATÉGIA DE FORMAÇÃO DO CAMPO PROFISSIONAL …........................................................................221

5.3.2.1 A Rede Unida: enfrentando o Ministério da Educação ................................................................221

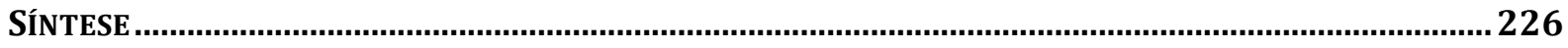

6. MOVIMENTO PELA REFORMA SANITÁRIA NO GOVERNO LULA (2003-2006).................. 228

6.1 CONJUNTURA: EXPECTATIVAS, NOVA COALIZÃO NO PODER E FOMENTO À PARTICIPAÇÃo .................. 228

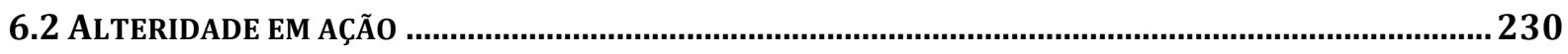

6.2.1 DiAGNóSTICO E PROGNÓSTICO do MOVIMENTO PELA REFORMA SANITÁRIA: SUS E DEMOCRACIA .......231

6.2.2 EVENTOS E ATORES DO MOVIMENTO PELA REFORMA SANITÁRIA ..............................................................233

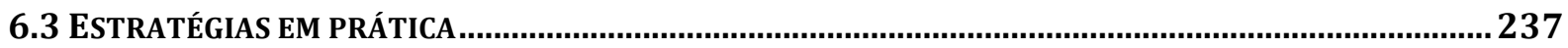

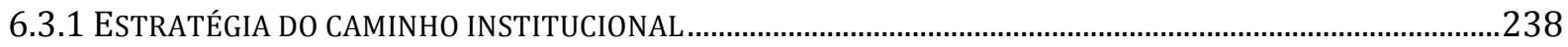

6.3.1.1 Reféns do repertório de ação: luta pelos recursos financeiros ...............................................238

6.3.1.2 Mobilizando o Estado em prol do movimento …………..............................................................242

6.3.2 ESTRATÉGIA DE FORMAÇÃO DO CAMPO PROFISSIONAL ….........................................................................248

6.3.2.1 Institucionalização mobilizadora: Educação Popular e Saúde no Ministério da Saúde...248

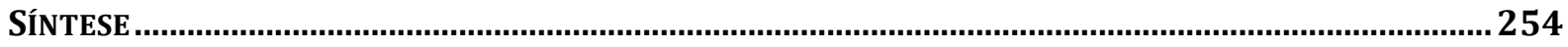

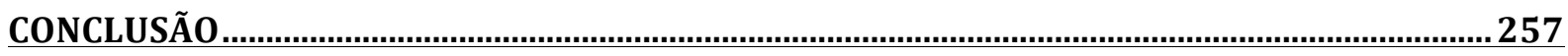

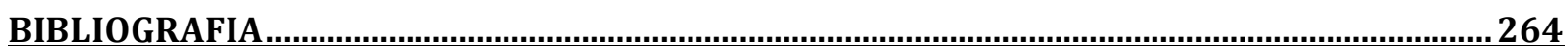

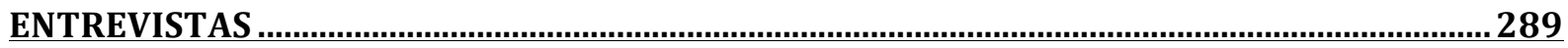

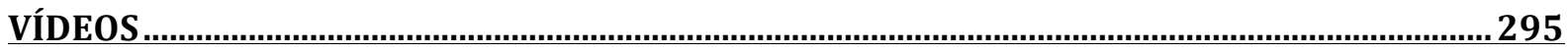





\section{ÍNDICE DE FIGURAS}

Figura 1 - Categorias do conceito ampliado de repertório de ação dos movimentos sociais.............. 81 


\section{ÍNDICE DE SIGLAS}

\begin{tabular}{|c|c|}
\hline ABEM & Associação Brasileira de Educação Médica \\
\hline ABEn & Associação Brasileira de Enfermagem \\
\hline ABRAMGE & Associação Brasileira de Medicina de Grupo e Empresarial \\
\hline ABRASCÃO & Congresso de Saúde Coletiva \\
\hline ABRASCO & Associação Brasileira de Pós-Graduação em Saúde Coletiva \\
\hline ABRASME & Associação Brasileira de Saúde Mental \\
\hline Abres & Associação Brasileira de Economia de Saúde \\
\hline AIS & Ações Integradas de Saúde \\
\hline Ampasa & Associação Nacional do Ministério Público de Defesa de Saúde \\
\hline AMSESP & Associação dos Médicos Sanitaristas do Estado de São Paulo \\
\hline ANC & Assembleia Nacional Constituinte \\
\hline Anepop & Articulação Nacional de Extensão Popular \\
\hline Aneps & Articulação Nacional de Movimentos e Práticas de Educação Popular e Saúde \\
\hline ANMR & Associação Nacional dos Médicos Residentes \\
\hline Asems & Associação dos Secretários Municipais de São Paulo \\
\hline Assedisa & Associação Estadual dos Dirigentes de Saúde \\
\hline BNDE & Banco Nacional de Desenvolvimento Econômico \\
\hline BVS-ECOS & Biblioteca Virtual de Saúde em Economia da Saúde \\
\hline CADRHU & Capacitação em Desenvolvimento de Recursos Humanos de Saúde \\
\hline Cebes & Centro Brasileiro de Estudos de Saúde \\
\hline Cefor & Centros de Formação de Recursos Humanos \\
\hline Ceme & Central de Medicamentos \\
\hline Cemig & Companhia Energética de Minas Gerais \\
\hline CFT & Comissão de Finanças e Tributação \\
\hline CGDRHS & Coordenação Geral de Desenvolvimento de Recursos Humanos \\
\hline CGT & Confederação Nacional dos Trabalhadores \\
\hline CIB & Comissão Intergestores Bipartite \\
\hline Cinaem & Comissão Interinstitucional Nacional de Avaliação das Escolas Médicas \\
\hline Ciplan & Comissão Interministerial de Planejamento \\
\hline CIS & Comissões Interinstitucionais de Saúde \\
\hline CISM & Comissão Intersetorial de Saúde Mental \\
\hline CIT & Comissão Intergestores Tripartite \\
\hline CLIS & Comissão Local de Saúde \\
\hline CIMS & Comissão Municipal de Saúde \\
\hline CNA & Confederação Nacional da Agricultura \\
\hline CNBB & Conferência Nacional dos Bispos do Brasil \\
\hline $\mathrm{CNC}$ & Confederação Nacional do Comércio \\
\hline CNI & Confederação Nacional da Indústria \\
\hline $\mathrm{CNPq}$ & Conselho Nacional de Desenvolvimento Científico e Tecnológico \\
\hline $\mathrm{CNRH}$ & Conferência Nacional de Recursos Humanos \\
\hline CNRS & Comissão Nacional de Reforma Sanitária \\
\hline CNS & Conselho Nacional de Saúde \\
\hline Conam & Confederação Nacional das Associações de Moradores \\
\hline Conasems & Conselho Nacional de Secretários Municipais de Saúde \\
\hline CONASP & Conselho Nacional de Administração da Saúde Previdenciária \\
\hline CONASS & Conselho Nacional de Secretários de Saúde \\
\hline
\end{tabular}




\begin{tabular}{|c|c|}
\hline CONTAG & Confederação Nacional dos Trabalhadores na Agricultura \\
\hline COSEMS-MT & Conselho de Secretários Municipais de Saúde do Mato Grosso \\
\hline COSEM-SP & Conselho de secretários Municipais de Saúde de São Paulo \\
\hline CRIS & Comissões Regionais Interinstitucionais de Saúde \\
\hline CUT & Central Única dos Trabalhadores \\
\hline $\mathrm{DAB}$ & Departamento de Atenção Básica \\
\hline DEGES & Departamento de Gestão da Educação na Saúde \\
\hline Denem & Direção Executiva Nacional de Estudantes de Medicina \\
\hline DFID & Department for International Development \\
\hline $\mathrm{EC}$ & Emenda Constitucional \\
\hline ENEPS & Encontro Nacional de Educação Popular em Saúde \\
\hline ENSP & Escola Nacional de Saúde Pública \\
\hline EOP & Estrutura de oportunidades políticas \\
\hline $\mathrm{FBH}$ & Federação dos Hospitais Brasileiros \\
\hline Fenaess & Federação Nacional dos Estabelecimentos de Serviços de Saúde \\
\hline FGV & Fundação Getúlio Vargas \\
\hline $\mathrm{FHC}$ & Fernando Henrique Cardoso \\
\hline Finep & Financiadora de Estudos e Projetos \\
\hline FioCruz & Fundação de Osvaldo Cruz \\
\hline FNDCT & Fundo Nacional de Desenvolvimento Científico e Tecnológico \\
\hline FNM & Confederação Nacional dos Médicos \\
\hline FORPROEX & Fórum de Pró-Reitores de Extensão das Universidades Públicas Brasileiras \\
\hline FUNASA & Fundação Nacional de Saúde \\
\hline FUNTEC & Fundo de Desenvolvimento Técnico-Científico \\
\hline GERUS & Curso de Especialização em Gerência de Unidades Básicas \\
\hline IAL & Instituto Adolfo Lutz \\
\hline IBAM & Instituto Brasileiro de Administração Municipal \\
\hline IBGE & Instituto Brasileiro de Geografia e Estatística \\
\hline IDA & Integração Docente-Assistencial \\
\hline INAMPS & Instituto Nacional de Assistência Médica da Previdência Social \\
\hline INE & Instituto Nacional de Estatística \\
\hline INPS & Instituto Nacional da Previdência Social \\
\hline IPEA & Instituto de Planejamento Econômico e Social \\
\hline JUC & Juventude Universitária Católica \\
\hline LOS & Lei Orgânica de Saúde \\
\hline MARE & Ministério da Administração e Reforma do Estado \\
\hline MDB & Movimento Democrático Brasileiro \\
\hline MEC & Ministério da Educação \\
\hline MOPS & Movimento Popular de Saúde \\
\hline MORHAN & Movimento de Reintegração de Pessoas Atingidas pela Hanseníase \\
\hline MP & Ministério Público \\
\hline MPAS & Ministério de Previdência e Assistência Social \\
\hline $\mathrm{MPF}$ & Ministério Público Federal \\
\hline MS & Ministério da Saúde \\
\hline NDS & Núcleo de Desenvolvimento de Saúde \\
\hline NESCO & Núcleo de Estudos em Saúde Coletiva \\
\hline NESCON & Núcleo de Estudos em Saúde Coletiva e Nutrição \\
\hline NESP & Núcleo de Estudos em Saúde Pública \\
\hline NMTR & Movimento de Mulheres Trabalhadoras Rurais \\
\hline NOB & Norma Operacional Básica \\
\hline
\end{tabular}


OMS

OPAS

PACS

PAFCS

ParticipaSUS

PASEP

PBDCT

PCB

PCdoB

PEC

PDS

PEPPE

PESES

PIASS

PIDA

PIS

PMDB

PNCS

PNCTI/S

PND

PPREPS

PREV-SAÚDE

PROAHSA

PROFAE

PSF

PT

REDE ECOS

Redepop

REME

SCTIE

SEGEP

SESAC

SESU

SGP

SGTES

SIOPS

SISSNM

SNS

SSP

SUDS

SUS

UERJ

UFMT

ULBRA

UNB

UNDIME
Organização Mundial da Saúde

Organização Pan-Americana de Saúde

Programa de Agente Comunitário de Saúde

Programa de Apoio ao Fortalecimento do Controle Social

Política Nacional de Gestão Estratégica e Participativa no SUS

Programa de Formação do Patrimônio do Servidor Público

Plano Básico de Desenvolvimento Científico-Tecnológico

Partido Comunista Brasileiro

Partido Comunista do Brasil

Proposta de Ementa Constitucional

Partido Democrático Social

Programa de Estudos Populacionais e Epidemiológicos

Programa de Estudos Socioeconômicos em Saúde

Programa de Interiorização de Ações de Saúde e Saneamento

Programa de Integração Docente-Assistencial

Programa de Integração Social

Partido do Movimento Democrático Brasileiro

Plenária Nacional dos Conselhos de Saúde

Política de Ciência, Tecnologia e Inovação em Saúde

Plano Nacional de Desenvolvimento

Programa de Preparação Estratégica de Pessoal em Saúde

Programa Nacional de Serviços Básicos de Saúde

Programa de Estudos Avançados em Administração Hospitalar e de Sistemas de Saúde

Projeto de Profissionalização dos Trabalhadores da Área de Enfermagem

Programa Saúde da Família

Partido dos Trabalhadores

Rede de Economia da Saúde

Rede de Educação Popular e Saúde

Movimento de Renovação Médica

Secretaria de Ciência, Tecnologia e Insumos Estratégicos

Secretaria de Gestão Estratégica e Participativa

Semana de Estudos sobre Saúde Comunitária

Secretaria de Ensino Superior

Sistema de Gerência de Projetos

Secretaria de Gestão do Trabalho e da Educação na Saúde

O Sistema de Informação sobre o Orçamento Público de Saúde

Sistema Integrado de Prestação de Serviços de Saúde no Norte de Minas Gerais

Serviço Nacional de Saúde

Serviço de Saúde Pública

Sistemas Unificados e Descentralizados de Saúde

Sistema Único de Saúde

Universidade Estadual do Rio de Janeiro

Universidade Federal do Mato Grosso

Universidade Luterana do Brasil

Universidade de Brasília

União Nacional dos Dirigentes Municipais de Educação 


\section{Introdução}

Primeiro álbum de fotografias. No fundo de uma foto do ginásio de Brasília, ocupado por milhares de participantes da $8^{a}$ Conferência Nacional de Saúde, em 1986, vislumbramos a faixa que diz: "Saúde e democracia". Outra foto registra um grupo de pessoas vestidas de forma comum, diante de um deputado, entregando-lhe um documento, durante a Constituinte em 1987. Na terceira, de 2009, aparecem os participantes da Marcha dos Usuários pela Reforma Antimanicomial que, com o grito "Brasília vai ouvir nossa voz", reuniu mais de três mil profissionais da área de saúde e usuários nas ruas da capital do país. Segundo álbum. Notamos a imagem do militante do Movimento Sanitário, Hésio Cordeiro, assumindo a presidência da mais importante instituição de saúde, em 1985, o Instituto Nacional de Assistência Médica da Previdência Social (Inamps). Em seguida, de 1987, o registro fotográfico do V Encontro dos Secretários Municipais de Saúde, em Londrina. Na terceira foto aparecem os participantes do lançamento da Rede de Educadores Populares em Saúde, no Ministério da Saúde, em 2005. Se as fotos do primeiro álbum remetem ao que convencionamos chamar de movimentos sociais e suas facetas, com mobilizações maciças e participação da comunidade na gestão pública, os cliques reunidos no segundo álbum constituem, à primeira vista, cenas da administração pública, ligadas à estrutura do Estado brasileiro, sua gestão federativa e implementação de programas. Ora, se estes dois álbuns tratam do mesmo conjunto de atores, todos pertencentes ao Movimento Sanitário/pela Reforma Sanitária1, a nomenclatura existente na Teoria dos Movimentos Sociais nos obriga a repartir as fotos em duas esferas distintas: uma reservada às Mobilizações de Protestos dos movimentos sociais e outra destinada aos Processos de Políticas Públicas.

O presente trabalho aponta justamente essa insuficiência da Teoria dos Movimentos Sociais na medida em que suas categorias não conseguem dar conta do Movimento Sanitário/pela Reforma Sanitária, que vem se mobilizando desde

\footnotetext{
${ }^{1}$ A denominação Movimento Sanitário era utilizada até meados dos anos 1980, quando entrou também em uso a de Movimento pela Reforma Sanitária. Os capítulos empíricos acompanharão essa mudança de nomenclatura.
} 
meados dos anos 1970, composto, dependendo do período, por redes de profissionais de saúde, estudantes, acadêmicos, trabalhadores de saúde pública, diversas associações, sindicatos e movimentos populares de saúde para lutar pelo acesso universal à saúde como direito do cidadão brasileiro e dever do Estado. Apesar do radicalismo da demanda nas fases iniciais de sua trajetória, nos anos 1970 e 1980, o movimento recorreu pouco a protestos. Todavia, atuou por meio de outras ações como o lobby parlamentar, a ocupação de cargos no Estado, a apropriação de espaços coletivos estatais para as finalidades do movimento, a criação de associações em torno das questões mais candentes, além de fomentar, ao longo dos trinta anos, eventos recorrentes e regulares nos quais a defesa do sistema universal, gratuito e integral de saúde contra seus opositores sempre esteve presente.

O leque das ações desenvolvidas pelos atores do Movimento Sanitário/pela Reforma Sanitária não encontra ressonância analítica nas abordagens dos Movimentos Sociais. Essas privilegiaram os protestos como $a$ forma de atuação dos movimentos, restringindo a questão da institucionalização à rotinização dos protestos, bem como à profissionalização e à burocratização das organizações do movimento (Tarrow, 1998; Meyer; Tarrow, 1998; McAdam; McCarthy; Zald, 2006; Tilly; Tarrow, 2007). As tentativas de ampliar o conceito de ação dos movimento sociais para além da política de confronto e ação fora das instituições (Guigni; Passy, 1998; Goldstone, 2003; Abers, Serafim; Tatagiba, 2011) não têm sido incorporadas nas principais abordagens. O Movimento Sanitário/pela Reforma Sanitária constitui uma anomalia em relação à Teoria dos Movimentos Sociais e, com isso, o seu estudo pode contribuir para o desenvolvimento teórico no sentido de alargar, em relação ao estado presente da literatura, o conceito de "repertórios de ação dos movimentos sociais" ao incluirmos nele, ao lado das ações "fora das instituições", as ações "via instituições".

Se a Teoria dos Movimentos Sociais abandona esses atores quando eles, metaforicamente, saem das ruas, eles acabam por reaparecer nas abordagens de Políticas Públicas, cujo foco está na agência e nas instituições políticas. Em tais abordagens, são oferecidos instrumentos analíticos e metodológicos capazes de captar uma variedade de atores em processos de políticas públicas, tais como os conceitos de "coalizões de defesa", de Sabatier (Sabatier; Weible, 2007); 
“comunidades de especialistas", de Kingdon (1995); "domínios de política pública", de Knoke (Pappi; Knoke, 1991); ou "estruturas de implementação", de Hjern e Porter (1981). No entanto, a ênfase nessas categorias acaba por incluir nas análises apenas os atores relevantes (e não aqueles em constituição) e por selecionar a atuação de atores considerados os mais influentes no processo (e não os repertórios de formas de ação). A constituição, a coordenação e o repertório de ação coletiva dos atores estão fora de seu escopo de interesse analítico, e isso não por uma insuficiência, mas porque tais dimensões não fazem parte das questões que essas abordagens propõem. Uma vez que elas não se permitem pensar tais facetas, deixam de compreender a atuação de atores do movimento antes que eles se tornem relevantes e também como se tornaram proeminentes.

Nesta tese, optamos por trabalhar com a Teoria dos Movimentos Sociais, porque, apesar dos limites que ela apresenta, oferece categorias e proposições capazes de analisar o conjunto amplo de ações e atores conectados pelo sentido comum - no caso, o da luta pelo acesso universal à saúde como direito do cidadão e dever do Estado - sem limites postos pela forma organizacional assumida ou categorias sociológicas já consagradas como "sindicatos" ou "profissões". Partimos da definição de Diani, segundo a qual movimentos sociais "are defined as networks of informal interaction between a plurality of individuals, groups and/or organizations, engaged in political or cultural conflicts, in the basis of shared collective identities" (Diani, 1992: 1), direcionando a escolha das categorias analíticas que guiarão o estudo. A principal categoria, em função da insuficiência que o Movimento Sanitário/pela Reforma Sanitária aponta na teoria, é a dos "repertórios de ação dos movimentos sociais" (Tilly, 2008).

O foco nos repertórios de ações tem um objetivo que vai além da tipologia e registro. Partimos do pressuposto de que os atores que se mobilizam num movimento social buscam abandonar a condição de contingência e tornar a sua presença nas instituições políticas estável no tempo. O movimento social possui a marca da contingência (talvez, se não a tivesse, não seria um "movimento") e, ao mesmo tempo, os seus atores buscam sair dessa condição. Assim, ao analisar as ações via instituições mediante a ocupação de cargos ou a participação institucionalizada, por exemplo, prestaremos atenção aos episódios nos quais os atores disputam pontos 
de acesso e influência ao Estado, sejam eles parciais e pontuais (Skocpol, 1995); sejam eles como campos privilegiados de atuação, dotados de barreiras de entrada para novos atores, munidos de procedimentos de admissão e certificação e acesso privilegiado a recursos públicos e privados, isto é, domínios de agência (Gurza Lavalle; Houtzager; Castello, 2011: 10). Por meio deles, os atores, antes invisíveis do ponto de vista da sua relevância política, entendida como capacidade de incidir na política, passam a importar nas abordagens de Políticas Públicas.

A contribuição analítica deste trabalho pode ser sintetizada em três pontos que implicam correções e reespecificações no arcabouço conceitual da Teoria dos Movimentos Sociais. Em primeiro lugar, no esforço de ampliar o escopo analítico dos repertórios de ação dos movimentos sociais, introduziremos a distinção entre as ações "fora das instituições", que constituem o foco da Teoria dos Movimentos Sociais, e as ações "via instituições", que têm sido negligenciadas na literatura. Nestas, os atores do movimento social operam de acordo com as regras institucionais, porém, não raramente, recorrem a adaptações que dotam a sua atuação de caráter inovador, fato pouco ressaltado na literatura que associa institucionalização a burocratização e rotinização. Assim, aplicaremos uma distinção interna na categoria de ações via instituições, diferenciando as ações "convencionais" e as "não-convencionais", estas entendidas como aquelas que colocam as autoridades diante das situações novas e aumentam a capacidade de mobilização do movimento. O aspecto não convencional das ações via instituições permite observar como os atores dos movimentos sociais tentam transformar o Estado, não só de acordo com as suas demandas, mas também de acordo com o seu modo de ação, em termos de mobilização e do repertório de ação. O foco nas ações via instituições autoriza o pesquisador a acompanhar os atores do movimento social no interior do Estado, na condição de atores do movimento, e revela como eles usam cargos e espaços do Estado; também como criam organizações e espaços, aparentemente estatais, mas que são conduzidos pelo movimento e em prol de suas causas; por fim, como transformam a própria ação do Estado em um instrumento de mobilização do movimento.

O Movimento Sanitário/pela Reforma Sanitária optou, desde o início da sua articulação, pela estratégia do caminho institucional como linha norteadora das suas 
ações, ao lado da de formação do campo profissional. Para colocá-las em prática, valeram-se, frequentemente, de táticas tais como a ocupação de cargos e a apropriação de espaços estatais para as finalidades do movimento. Seu uso era importante não só do ponto de vista da introdução das ações reformistas, mas da capacidade de recrutamento de novos adeptos, da mobilização e vivências coletivas nas quais a identidade coletiva podia ser constantemente construída e reconstruída. Uma das expressões mais evidentes do uso movimentista do Estado foi a organização da ação coletiva e o estabelecimento da representação política dos secretários municipais de saúde pelos militantes do movimento, ainda nos anos 1980. Outra, já no período mais recente, mostrou como, mediante a entrada sem precedentes do movimento nos principais cargos de direção no Ministério da Saúde, os militantes levaram às ultimas consequências as suas estratégias. Não apenas institucionalizaram as suas demandas, tornando-as diretrizes das politicas setoriais, como também, ao mesmo tempo, definiram a formação na sua visão sobre a política pública e a mobilização de novos adeptos do movimento como conteúdos da ação do Estado.

Em segundo lugar, a análise do movimento social que recorre majoritariamente às ações via instituições em detrimento das ações fora das instituições e, entre essas, a de protestos, realça a importância da categoria de “organizações dos movimentos sociais". Não no sentido mais recorrentemente utilizado na teoria, isto é, como recurso para a articulação e organização das atividades de protesto, mas como instrumento de ação política do movimento (Clemens, 1993). A escolha do seu formato pelos atores do movimento se torna significativa e informa sobre o uso das táticas e da criação de pontos de acesso e influência no Estado.

É possível notar um leque das opções adotadas pelo movimento. Os atores constituíram uma entidade formal de representação política como modo de criar a capacidade de incidência na política pública. Recorreram também às formas abertas e de pouca formalização de organização de modo a aproveitar a capacidade de exercer a pressão sobre as autoridades de seus integrantes. Por fim, aproveitaram as próprias organizações como mobilizações nas quais o movimento apresenta-se como ator diante das autoridades. Esse é o caso do "ator-evento", categoria com a qual 
designamos aquele ator organizacional que se consubstancia apenas quando os seus integrantes estão reunidos. Tal reunião funciona como uma mobilização mediante a qual o movimento demonstra a sua força numérica ou o seu poder de representação e explicita sua identidade coletiva frente aos opositores.

Em terceiro lugar, argumentamos neste trabalho que a falta de protestos não significa a ausência de vivências nas quais ocorre o processo da reconstituição permanente do movimento. Assim, uma importante faceta dos movimentos sociais está nos eventos (Oliver; Myers, 2003) que eles organizam e dos quais participam. Entendemos os eventos como aqueles espaços coletivos de reunião, debate e mobilização nos quais o movimento social, que não recorre a protestos, pode representar-se como uma coletividade, redefinir os vínculos, repactuar os seus propósitos e finalidade, bem como articular novas ações, enfim, construir e reconstruir a sua identidade coletiva.

Na trajetória do Movimento pela Reforma Sanitária abundam esses eventos, tanto regulares quanto aqueles organizados de acordo com as necessidades da conjuntura. Nos seminários, conferências, simpósios, congressos etc. - eventos raramente associados a movimentos sociais, enquanto espaços de sua reprodução seus atores rompem, paulatinamente, com as clivagens acadêmica, profissional, governamental ou da "sociedade civil”, agregando esses públicos em torno de pautas e objetivos comuns. Não raramente, os eventos acolhem a organização de encontros e reuniões das vertentes do movimento e, muito frequentemente, seus coletivos constroem sua posição política diante da conjuntura, publicizando-a por meio de cartas e outros documentos de ampla circulação.

Em suma, ao ampliar o conceito de repertórios de ação dos movimentos sociais com a inclusão da categoria de ações via instituições, ao incorporar as organizações de movimentos como instrumentos de ação política e os eventos como a expressão de sua mobilização, alargamos a compreensão dos movimentos sociais para além da dimensão dos protestos. Graças a esse movimento analítico, encontramos empiricamente a mobilização onde pairava ar de desmobilização, e inovação onde havia aparentemente apenas expressões de burocratização e rotinização. E, por fim, ao considerar como ação do movimento aquela que se processa nas instituições políticas, é possível ultrapassarmos a separação analítica 
entre movimentos sociais, sociedade e Estado e, com isso, captar a sua mútua constituição.

Ainda nesta introdução, retomamos, em linhas gerais, as principais ênfases sobre o ator empírico chamado "Movimento Sanitário/pela Reforma Sanitária" encontradas na literatura. Optamos por apresentá-la na introdução, porque, embora ela tenha produzido uma série de distinções ricas, não o fez com base na Teoria dos Movimentos Sociais. Assim, não é com essa bibliografia que estabeleceremos o diálogo teórico-analítico, ainda que a utilizemos amplamente ao longo dos capítulos empíricos, para reconstruir a trajetória do movimento e as observações analíticas. Em seguida, descreveremos os procedimentos metodológicos adotados ao longo desta pesquisa, as principais fontes de coleta de evidências empíricas, bem como apresentaremos os principais pontos dos capítulos desta tese.

\section{Movimento Sanitário/pela Reforma Sanitária na literatura}

O Movimento Sanitário é retratado na literatura acerca do setor de saúde como um ator empírico importante, principalmente no período que vai dos anos 1970 ao início dos anos 1990. Existem alguns importantes trabalhos que o colocam no centro de análise, mas raros são aqueles que partem da Teoria dos Movimentos Sociais para discuti-lo. Essa falta pode ser explicada, em parte, pela ausência de uma agenda sistemática de pesquisas sobre os movimentos sociais e a consequente falta de desenvolvimento teórico no Brasil nessa área (Silva, 2010). Uma das consequências desse fato é a dificuldade de estabelecer uma diálogo crítico com a produção existente em função das diferenças nas matrizes teórico-analíticas. Por isso, a sistematização da literatura a seguir adquire mais os traços de uma apresentação dos principais prismas e ênfases, principalmente em torno das formas de atuação do movimento, do que de um debate no sentido de demonstrar insuficiências ou ausências em relação ao arcabouço teórico por nós utilizado. Vale ressaltar que os textos encontrados foram uma fonte essencial no levantamento de informações sobre o movimento na parte empírica desta investigação. Após uma breve 
contextualização da produção acadêmica brasileira sobre os movimentos sociais, centraremos nossa atenção nos textos que focam o Movimento Sanitário/Movimento pela Reforma Sanitária.

Faz parte do diagnóstico já estabelecido de que os movimentos sociais no Brasil deixaram de ser estudados dentro do marco das Teorias dos Movimentos Sociais após sua efervescência contestatória dos anos 1970, registrada e discutida então na perspectiva marxista, pelo prisma de autonomia e da não interação com o Estado. Os movimentos eram retratados por meio de formas variadas de protesto como o quebra-quebra, a invasão de terrenos, as mobilizações de protesto nos bairros etc., isto é, investigados pelo crivo das ações da política de confronto, desenvolvidas fora dos canais existentes de acesso ao Estado e fora das instituições (Jacobi, 1980; Boschi, 1987). A diminuição dos protestos levou uma parte dos analistas ao diagnóstico sobre a desmobilização dos movimentos, sobre sua cooptação ou ainda sobre o estabelecimento de relações clientelistas com o sistema político e seus atores tradicionais e à concomitante perda de interesse por movimentos como objeto de análise $^{2}$ (Telles, 1987; Gohn 2006).

Alguns poucos pesquisadores (Cardoso, 1984; Jacobi, 1987; Boschi 1987; Martes, 1990) esboçaram novas proposições a respeito das interações entre os movimentos e o Estado. Cardoso, por exemplo, defendia que as formas de ação dos movimentos na passagem dos anos 1970 aos 1980 teriam sido influenciadas pelas mudanças do Estado tais como a centralização e o hiperdesenvolvimento, a reforma administrativa e a agilização dos serviços públicos (Cardoso, 1984). Esse argumento permitia entender as transformações em curso dos dois lados - Estado e movimento social -, sem enquadrá-las, necessariamente, em termos de clientelismo ou cooptação. As abordagens como a de Cardoso não resultaram, todavia, numa agenda sólida e contínua de pesquisa, e se as interações entre os movimentos sociais e o Estado voltaram a ocupar a atenção dos pesquisadores a partir do final dos anos 1990, esse retorno se deu sob um prisma bem específico. Os movimentos apareciam como integrantes dos "espaços participativos" tais como conselhos, conferências ou

\footnotetext{
${ }^{2}$ A interpretação sociológica deste viés teórico e normativo na literatura é feita com desenvoltura e fôlego por Vera Telles (1987).
} 
orçamento participativo, ou seja, como partes de um arcabouço teórico preocupado em entender essas novas instituições e não os movimentos sociais.

Diante desse percurso, aqui apenas esboçado, não deve surpreender a conclusão sobre a produção acadêmica relacionada com os movimentos sociais no Brasil nos anos 2000, elaborada a partir da avaliação das publicações voltadas ao tema em quatro revistas (Silva, 2010). O campo de estudos de movimentos sociais no Brasil pode ser caracterizado, na visão do autor, pela "profunda fragmentação em termos epistemológico, teórico e temático e pela falta de agenda comum da produção nacional" (Silva, 2010: 4). Os três aspectos preponderantes da produção sobre o tema seriam a persistência do foco normativo-prescritivo - daquilo que o movimento deveria ser como ponto de partida dos estudos; uma restrição do campo de estudos a um conjunto de movimentos e organizações e os esforços ainda muito incipientes da construção de modelos analíticos ${ }^{3}$ (Silva, 2010: 4). Esse diagnóstico evidencia a razão pela qual optou-se, nesta tese, a travar o diálogo com a Teoria dos Movimentos Sociais cujo principais expoentes se encontram no hemisfério norte.

No que se refere à literatura sobre a política de saúde, o Movimento Sanitário é reconhecido como um conjunto importante de atores, especialmente nas análises que se referem ao período até o início dos anos 1990 (Fleury, 1987; Dâmaso, 1989; Lucchesi, 1989; Cohn, 1989; Menicucci, 2007; BRASIL; MS; CNS, 2006). Em relação aos anos 1990, houve alguns diagnósticos sobre sua desmobilização (Escorel, 1998; Menicucci, 2007), evidenciada pela concentração de seus atores em torno dos espaços institucionais e questões corporativistas, em detrimento da causa da Reforma Sanitária. Nas análises setoriais das décadas de 1990 e 2000, que correspondem à implementação do novo sistema de saúde, os atores são retratados primordialmente em seus papéis institucionais, assumidos no interior do arcabouço legal do Sistema Único de Saúde (SUS) e, portanto, desencarnados de sua atuação movimentista. Assim, o Movimento Sanitário/pela Reforma Sanitária, na maioria dos casos, desapareceu das análises da literatura setorial, ainda que ela fizesse a avaliação dos avanços e retrocessos em relação ao ideário da Reforma Sanitária com o qual o movimento era identificado (Fleury, 1994; Merhy, 1991; Campos, 1991; Vianna, 1992;

${ }^{3}$ Alguns poucos trabalhos pioneiros que enfrentam as questões teóricas e visam a construção de modelos teóricos foram citados no primeiro capítulo. 
Barros; Porto, 2002; Cordeiro, 2001; Cohn; Elias, 2005; Ugá; Marques, 2005), com algumas exceções (Arretche, 2005; Paim, 2008).

Os trabalhos que tornam o Movimento Sanitário/pela Reforma Sanitário o ator principal de suas análises ${ }^{4}$, conforme já assinalado, com a exceção do estudo de Weyland (1995), não se engajam em um debate com a Teoria dos Movimentos Sociais. A apresentação pretende mostrar a abrangência do conhecimento acumulado sobre o movimento e atentar para o fato de que o seu repertório de ação "via instituições", embora não constitua o cerne analítico dos trabalhos, já está posto em evidência.

O trabalho de maior fôlego sobre o Movimento Sanitário na sua fase da formação é o de Sarah Escorel, intitulado Reviravolta de Saúde: origem e articulação do movimento sanitário que já informou vários outros estudos, inclusive a presente tese. A autora busca entender como se deu a formação do Movimento Sanitário sob o prisma da categoria de "identidade coletiva". Assim, organiza a reconstrução histórica do movimento, entre os anos de 1974 e 1979, em dois blocos. No primeiro, faz a reconstituição minuciosa de atores do movimento, distinguindo três vertentes acadêmica, profissional e estudantil - que são analisadas pelo prisma organizacional, de atividades desenvolvidas e eventos realizados. O segundo bloco busca mostrar como se deu a integração e a construção das experiências comuns, focando os programas de saúde implementados pelos governos locais e federal. Por não constituir o eixo central de sua análise, a autora faz apenas referência ao repertório de ação do movimento, usando categorias nativas. Sublinha a adoção da estratégia de "ocupação de espaços" por meio da qual o movimento se constituiu “conscientemente" como "uma força contra-hegemônica nas instituições setoriais" (Escorel; 1998: 188), procurando sua ampliação nos espaços de poder a fim de viabilizar as suas propostas de transformação. Ao chegar ao início dos anos 1990, a autora anuncia a desmobilização do Movimento Sanitário, entendida como distanciamento da prática política: após ter conseguido inscrever seu projeto na Constituição de 1988, suas vertentes teriam refluído para os lugares de origem e se

${ }^{4}$ Não mencionaremos aqui os numerosos trabalhos feitos sobre os atores ou vertentes específicos do Movimento Sanitário/ pela Reforma Sanitária que são reconhecidos e utilizados ao longo dos capítulos empíricos. 
centrado nas suas questões internas: sindicatos com as questões corporativas e a academia com a produção científica propriamente dita (Escorel, 1998: 197 e 1998).

O trabalho de maior envergadura temporal, pois estende sua análise até meados dos anos 2000 e se guia parcialmente pela categoria de movimento social, é a obra de Paim (2008), Reforma Sanitária Brasileira: contribuição para a compreensão e crítica, na qual o autor procura analisar a emergência e o desenvolvimento da Reforma Sanitária brasileira mediante as seguintes dimensões: ideia, proposta, projeto e movimento (Paim, 2008: 32). Sua narrativa reconstrói a trajetória setorial desde os anos 1970 e chega a meados dos anos 2000. Diferente dos diagnósticos que indicam a desmobilização, Paim mostra a continuidade do movimento ao longo dos anos 1990 e 2000, apontando para as suas transformações. Defende que os atores do Movimento Sanitário - e ele próprio é um dos seus militantes - foram capazes de uma "atuação autônoma" e de "articulações necessárias" com as diversas instâncias do Estado, sem comprometer com isso sua atuação como movimento. O autor nota ainda as rotinização e burocratização das formas organizacionais do movimento e, nesses casos particulares, questiona seu comprometimento e pertencimento ao mesmo. No capítulo específico dedicado às estratégias e aos atores do movimento da Reforma Sanitária brasileira faz um apanhado das principais formas de ação utilizadas ao longo tempo. Ele as identifica a partir dos termos utilizados pelos atores do movimento: a "difusão e ampliação da consciência sanitária" (termo usado por Fleury, 1997), “guerra de posições" , “estratégia quase de guerrilha" e "via parlamentar" (os três termos de Rodrigues Neto, 1997), mas não são elas que guiam sua narrativa e análise (Paim, 2008: 274-278).

O Movimento Sanitário é identificado frequentemente com a estratégia de atuação "por dentro do Estado" (Doimo; Rodrigues, 2003), mas foi encontrado apenas um estudo que torna essa questão central em diálogo com a Teoria dos Movimentos Sociais. O texto de Weyland, Social movements and the State: the politics of health reform in Brazil (1995), focaliza a estratégia voltada ao Estado (state-centered strategy) do Movimento Sanitário pelo prisma dos seus efeitos na política setorial, no período que se estende desde os anos 1970 ao início dos 1990. Sua discussão se insere no debate com a Teoria dos Movimentos Sociais e, mais especificamente, na discussão sobre as condições que explicariam os "sucessos" e "fracassos" dos 
movimentos. Seu principal argumento é o de que a teoria, ao separar analiticamente os movimentos sociais do Estado, não dá conta dos movimentos semelhantes ao Sanitário: "I argue that such society-centered approach does not provide an adequate understanding of the efforts of Brazil's health reform movement to affect public policy" (Weyland, 1995: 1700). No caso do Movimento Sanitário, a estratégia centrada no Estado teria sido adotada pela impossibilidade de ganhar um grande respaldo popular. Todavia, em razão dos obstáculos institucionais, mais especificamente, a oposição da burocracia, do setor privado e dos políticos clientelistas, teve resultados muito limitados (Weyland, 1995: 1702 e 1708). O desafio de abranger simultaneamente as ações do movimento, seus efeitos nas políticas e dos obstáculos e opositores acaba resultando numa análise superficial do repertório de ação do movimento, no qual o autor foca, de fato, a ocupação de cargos no nível federal. Opera também com as fronteiras muito reduzidas do Movimento Sanitário (Weyland, 1995: 1704), excluindo, por exemplo, a vertente municipalista e não considerando a ampliação de suas fileiras na transição democrática e durante a Assembleia Constituinte.

Por trás da avaliação de que a ação dos sanitaristas por dentro do Estado fracassou em relação aos objetivos iniciais, aparece o pressuposto do autor sobre a inflexão radical. Essa seria, na visão dele, a forma eficiente de mudar o status quo que, no entanto, o impediu de valorizar as alterações paulatinas por meio das quais os atores do movimento começaram, por exemplo, o processo da municipalização de serviços, e que são classificadas por ele apenas como "isoladas tentativas de reformas" (Weyland, 1995: 1709). Essas isoladas tentativas de reformas são vistas por Falleti (2010) como importantes mudanças incrementais introduzidas pelos atores do Movimento Sanitário que levaram à reformulação do setor de saúde no Brasil. Num texto publicado quinze anos depois do trabalho de Weyland, Falleti se pergunta como foi possível a universalização do sistema de saúde no Brasil, apesar de fortes obstáculos e barreiras políticas e, com isso, parte do diagnóstico oposto ao de Weyland. Defende que a implementação do Sistema Único de Saúde, ao longo dos anos 1990, foi resultado de mudanças graduais introduzidas antes da aprovação da Constituição de 1988. A extensão de serviços de saúde à população rural e aos desempregados pelo regime militar como forma de legitimar sua dominação frente 
ao crescente ativismo rural teria sido aproveitada pelo Movimento Sanitário para colocar em prática o seu modelo de Medicina Social, o que teria sido possível em função da expansão da cobertura e consequente maior permeabilidade do Estado. A autora reconhece no movimento três tipos de táticas: i) produzir e disseminar suas propostas de reformas; ii) ocupar as posições; iii) fazer lobby no Congresso (Falleti, 2010: 49), dando mais atenção à segunda modalidade tática. Tanto Weyland como Falleti restringem o movimento a duas organizações do movimento, a Abrasco (Associação Brasileira de Saúde Coletiva) e o Cebes (Centro Brasileiro de Estudos de Saúde). É em função desse enfoque restrito que o Conasems (Conselho Nacional de Secretarias Municipais de Saúde), como ator de peso responsável pela implementação nos anos 1990, surge "de repente", ainda que seja uma vertente do Movimento Sanitário, desde os anos 1970.

Ancorados em diferentes matrizes teóricas, os trabalhos aqui referidos reconhecem a existência do Movimento Sanitário, embora, em grande parte, restrinjam a sua atuação às décadas de 1970 e 1980 e sublinham a adoção da estratégia de atuação por dentro do Estado, focando principalmente a tática de ocupação de cargos. Tendo em vista esse diagnóstico, o foco do presente trabalho no repertório de ações via instituições do Movimento Sanitário/pela Reforma Sanitária e a expansão do eixo temporal para os anos 1990 e 2000 tendem a contribuir para adicionar mais uma análise desse importante ator societal que é esse Movimento Sanitário.

Fazer um trabalho de pesquisa sobre o Movimento Sanitário/pela Reforma Sanitária significa também poder contribuir para a compreensão do objetivo que guia as ações desses atores: a luta - e uso essa palavra com a carga normativa que ela possui - pelo acesso universal à saúde como direito do cidadão e dever do Estado.

\section{Procedimentos metodológicos e desenho da pesquisa empírica}

A pesquisa empírica foi conduzida com base num estudo de caso, entendendo o caso como um fenômeno circunscrito temporal e/ou espacialmente, cujo estudo objetiva iluminar um conjunto maior de casos (Ragin, 1992: 5; Gerring, 2007: 21). O 
Movimento Sanitário no período entre 1974 a 2006 é o nosso caso, que pertence à classe maior composta por movimentos sociais. Sua seleção foi orientada teoricamente, na medida em que ele apresentava elementos que não poderiam ser captados pelas categorias existentes na Teoria dos Movimentos Sociais, apresentando-se, portanto, como um caso anômalo.

Um estudo de caso diferencia-se dos estudos com um grande número de casos por explorar em profundidade e intensidade as evidências empíricas de um único caso. A seleção dessas evidências depende do objetivo que guia o pesquisador (Ragin, 1992). Nesta tese, o norte foi dado pela questão teórico-analítica de descrever situações não cobertas pela Teoria de Movimentos Sociais. Nesse sentido, é possível dividir o estudo de caso, como o sugere Gerring (2007), em unidades menores, conformando um desenho do estudo de caso organizado e composto por “observações", que são unidades metodológicas de análise nas quais as questões teóricas se repõem com uma variação espacial ou temporal (Gerring, 2007: 49). Como nossa investigação não tem propósito explicativo e não se pauta pela relação entre variáveis independentes e dependentes, as observações podem ser qualitativamente diferentes umas das outras, seu número não precisa ser determinado e suas fronteiras podem se sobrepor. A força analítica das observações não se assentaria na comparação entre elas, mas na qualidade e na maneira como são analisadas e por isso se sugere, para cada uma dessas observações incomparáveis, um desenho próprio (Gerring, 2007: 181).

Assim, como o objetivo da pesquisa consiste em observar o repertório de ação do Movimento Sanitário/pela Reforma Sanitária, e também para tornar o trabalho factível no escopo do tempo e recursos de uma tese de doutorado, definimos cinco períodos que correspondiam, cada qual, ao mandato (cambiante em termos de anos) de um governo, nos quais reconstituímos, em primeiro lugar, o movimento pelo prisma de suas categorias analíticas constitutivas: i) diagnóstico, ii) prognóstico, iii) eventos e iv) atores. Com base nessas informações e na caracterização geral da conjuntura em cada governo, escolhemos, guiados pelo conceito do repertório e a tarefa aqui proposta de ampliá-lo, as observações mais pertinentes do ponto de vista do argumento teórico e das tendências observadas no movimento em um dado período. 
Desse modo, o estudo que aqui se apresenta foi organizado em cinco períodos diferentes, o que corresponde à variação temporal necessária de um estudo de caso. A periodização permitiu introduzir a variação no que se refere à relação das autoridades no poder com os movimentos sociais no sentido de maior ou menor abertura do sistema para a participação dos atores societais. Assim, estabelecemos os seguintes momentos: o regime militar no governo de Ernesto Geisel (1974-1979); a fase da transição democrática (1985-1989), com o governo de Sarney; e três governos democráticos: o governo Fernando Collor de Mello, avesso aos movimentos e ao princípio da participação da sociedade (1990-1992); o primeiro governo Fernando Henrique Cardoso, caracterizado pela fomento moderado à participação (1995-1998); e o primeiro governo de Luís Inácio Lula da Silva, caracterizado pelo fomento à participação (2003-2006). A divisão da análise da trajetória do Movimento Sanitário por período de governo objetivou disciplinar o olhar para o contexto maior, ainda assim circunscrito a um governo, no qual se inseriam os atores do movimento. Restringimos a análise ao nível nacional, o que teve consequências para a descrição não só do contexto, mas dos diagnósticos e prognósticos do movimento, de seus eventos e atores no sentido de não abranger as expressões nos níveis regionais ou da federação.

No interior de cada período, o estudo se dedicou à recuperação dos elementos constitutivos do movimento social de acordo com a definição adotada de Diani (1992), a saber, diagnóstico e prognóstico do movimento, seus principais eventos e atores. Começamos com a sistematização dos eventos, partindo do evento considerado o mais importante na literatura e associado à atuação do Movimento Sanitário/pela Reforma Sanitária. Foram eles: o $1^{\circ}$ Simpósio sobre a Política Nacional de Saúde ocorrido em 1979; a 8a Conferência, em 1986; a IX Conferência Nacional de Saúde, em 1992; o Ato Público de Defesa do SUS, em 1997; e o $8^{\circ}$ Simpósio sobre a Política Nacional de Saúde, em 2005.

Em seguida, foram sistematizados outros eventos com base nas informações colhidas em dois periódicos de duas principais e mais antigas organizações do movimento, partindo do pressuposto de que seriam citados os eventos fossem eles organizados pelos atores do movimento, fossem por eles identificados como importantes ou relevantes. Era uma forma de nos aproximarmos e delinearmos o 
universo de atores do movimento no nível nacional, ainda que sem fazer um mapeamento completo e estudo exaustivo a respeito. Aproveitamos também os eventos como fonte de informação sobre o diagnóstico e o prognóstico do movimento, usando para tanto os documentos tornados públicos e divulgados durante os eventos.

Com base nessa reconstituição, foram escolhidas, em cada um dos períodos, as observações propriamente ditas, construídas em torno da categoria principal - o repertório de ação dos movimentos sociais. Embora a descrição delas não siga um desenho metodológico comum, as observações foram divididas em dois tipos: episódios e processos. Os primeiros abrangem descrições pontuais, restritas a um evento, a uma ação de um militante ou de uma organização; os segundos capturam esses três elementos ao mesmo tempo numa perspectiva mais alongada no tempo. A título de exemplo, retratadas como episódios, as observações podem tanto descrever a trajetória de um sanitarista que ocupou um cargo no Estado como expressão da tática de ocupação de cargos quanto iluminar a organização de um evento, como a da Conferência Nacional de Saúde, como forma de apropriação do espaço estatal pelo movimento. O exemplo de um processo abrange a descrição dos eventos anuais dos militantes em torno do setor municipal de saúde, que junto com a ocupação de cargos, desembocaram ao longo do tempo na organização de um novo ator do

movimento. É importante mencionar que a periodização adotada para a reconstituição do movimento é pouco obedecida no caso do repertório de ação, porque o esforço de tornar a narrativa clara e compreensível nos levou, às vezes, a ultrapassar as fronteiras temporais delimitadas.

\section{Coleta de evidências empíricas}

A coleta de evidências sobre o repertório apoiou-se nas entrevistas com os ativistas do movimento, na pesquisa nos documentos produzidos pelo movimento nos períodos analisados e nos trabalhos de pesquisas sobre as organizações e vertentes do movimento. O processo da Reforma Sanitária é bastante estudado, e seus pesquisadores colocam à disposição da comunidade científica seus acervos de 
depoimentos. Para além da questão de custo e acesso, três vantagens do uso das entrevistas feitas por terceiros se tornaram evidentes. Em primeiro lugar, tivemos acesso às entrevistas realizadas há mais de vinte anos nas quais os atores falavam sobre o momento a eles contemporâneo - o que atenua o problema da memória -, como foi no caso das entrevistas com cinco ativistas realizadas no projeto Elaboração e implementação das políticas prioritárias do Inamps 1985-1988, realizadas entre 1987 e 1988. Em segundo lugar, as entrevistas disponibilizadas eram bastante extensas, obtidas em duas ou mais sessões, o que assegurava a riqueza de detalhes, como foram as do projeto História e perspectivas do Sistema Único de Saúde no Brasil com três extensas entrevistas, realizadas por longas horas, em 2004. Por fim, as entrevistas eram conduzidas pelos próprios atores do movimento, o que, na grande maioria dos casos, dispensava as introduções genéricas e levava os entrevistados ao cerne da sua atuação, traço que ficou evidente ao longo das entrevistas do projeto Construção do SUS. Histórias da Reforma Sanitária e do Processo Participativo ou nas consultadas do Projeto Memória e Patrimônio da Saúde Pública no Brasil: A Trajetória de Sérgio Arouca. A desvantagem de terem sido realizadas com outros focos que não o desta pesquisa foi atenuada pela investigação de dissertações e teses sobre as partes específicas, as quais também abundam na área de saúde pública. Em suma, quanto a entrevistas realizadas por terceiros, foram consultadas cerca de 50. Para os desdobramentos mais recentes do Movimento Sanitário/pela Reforma Sanitária, realizamos um conjunto de nove entrevistas.

Para reconstituir os eventos nos cinco períodos, a longevidade dos periódicos do movimento (e certamente das organizações que os produzem) foi o critério adotado para escolher dois desses periódicos das organizações do movimento mais perenes no tempo, a revista Saúde em Debate, do Cebes (1976 a 2006), e o Boletim da Abrasco (de 1982 a 2006). Com base neles, para cada período foi construída uma lista com os eventos, data e local de sua realização e, quando possível, entidades organizadoras e participantes. A análise dos eventos sistematizados desse forma permitiu a descrição dos tipos de eventos do movimento, bem como auxiliou no levantamento dos seus principais atores nacionais. A partir da lista dos eventos, referenciados pelos trabalhos sobre o setor de saúde e sobre o Movimento Sanitário/pela Reforma Sanitária, selecionamos de até dez eventos dos quais 
extraímos os documentos (cartas, moções etc.) para analisar o diagnóstico e prognóstico do movimento, procedendo dessa forma em cada período adotado. Recorremos também a outros periódicos identificados ou fomentados pelo movimento como a RADIS - Súmula, a RADIS - Comunicação em Saúde, o Jornal Presença do Conasems, a Revista do Conasems e a Revista Divulgação em Saúde para Debate.

\section{Estruturação dos capítulos}

No primeiro capítulo, apresentamos a Teoria dos Movimentos Sociais pelo prisma dos aspectos relacionados à institucionalização, mostrando a sua insuficiência para lidar com o nosso objeto de investigação. Explicitamos a razão pela qual não adotamos as abordagens de Políticas Públicas para tratar desse ator coletivo com intensa atuação no setor de saúde. Por fim, expomos o esquema utilizado na construção do objeto analítico, no qual aproveitamos algumas categorias da Teoria dos Movimentos Sociais, introduzindo uma correção no conceito de "repertórios de ação de movimentos sociais", de modo a poder contemplar a atuação do Movimento Sanitário.

No segundo capítulo, que inicia a sequência dos capítulos empíricos, retratamos o Movimento Sanitário na sua fase de formação, durante o governo de Ernesto Geisel (1974-1979), no regime militar. Nesse período, acompanhamos os seus eventos, ainda primordialmente de caráter acadêmico, a constituição dos primeiros atores e a construção das estratégias do movimento, a "do caminho institucional" e de "formação do campo profissional". Nesse início, os atores começam a experimentar um repertório de ação que inclui a "ocupação de cargos" e a “apropriação dos espaços” estatais para as finalidades do movimento.

O capítulo três capta o Movimento Sanitário/pela Reforma Sanitária na fase da transição democrática, entre 1984 e 1989. Na efervescência do contexto político, os eventos do movimento começam a integrar a área acadêmica com a setorial, e a estratégia do caminho institucional ganha desenvoltura. Os militantes do movimento buscam e alcançam altos cargos nas agências setoriais, apropriam-se de um evento 
nacional como forma de legitimação do seu projeto e ampliação de suas fileiras, criam um novo formato organizacional de modo a influenciar os trabalhos da Assembleia Constituinte por meio de lobby e mobilização. Começam a criar também um domínio de agência que abrange a representação política dos ocupantes de cargos das secretarias municipais de saúde.

No capítulo quatro, que analisa o período imediatamente posterior à transição, o do governo de Fernando Collor de Mello (1990-1992), o movimento já conta com as garantias constitucionais do novo sistema pelo qual lutou, mas o qual é colocado em xeque pelo governo do qual não faz parte. Descrevemos o repertório de ação empregado nessa situação, que, além do lobby, negociação com o Poder Executivo, abarca a ação da elaboração de leis. Esse capítulo também contempla as formas de atuação dos atores do movimento no que se refere à estratégia de formação do campo profissional, que conjuga a ocupação de cargos com a ação nos interstícios dos setores de políticas públicas. O movimento, em função do caráter não convencional de sua demanda, qual seja, a de subordinar a formação dos profissionais de saúde ao setor de saúde - tenta contornar, sem muito êxito, o domínio de agência do setor educacional. Ao mesmo tempo, seus atores avançam em seus eventos na integração entre os diversos públicos e alargam o escopo das áreas acadêmicas ligadas à saúde pública.

No capítulo cinco, observamos o movimento no governo de Fernando Henrique Cardoso (1995-1998). O processo da implementação do novo sistema já está em curso e, junto com ela, a instalação das instituições participativas que traduzem a diretriz defendida pelo movimento do controle social sobre o Poder Executivo. Novos atores do movimento marcam a entrada nesse período, atores que mostram que o movimento começa a aproveitar seu próprio repertório, ao mesmo tempo introduzindo elementos não convencionais nas suas ações. As atuações da Plenária Nacional dos Conselhos Nacionais em relação à estratégia do "caminho institucional" e da Rede Unida referente à de "formação" compõem esse capítulo ao lado do episódio que mostra o uso inédito da tática de accountability horizontal pelo movimento.

O último capítulo empírico, que abrange o primeiro mandato de Luís Inácio Lula da Silva (2003-2006), regista uma situação ambígua no movimento. Ao mesmo 
tempo em que os sanitaristas entram no Estado, numa ocupação de cargos sem precedentes no período da redemocratização, e levam às ultimas consequências suas estratégias, a sua principal bandeira, a luta pelo aumento e estabilidade de recursos para o setor, se processa por uma repetição monótona, ainda que disciplinada, do repertório de ação do tipo convencional. Se ao ocupar os cargos no Estado, o movimento consegue transformar a ação pública de acordo com os seus objetivos e modo de ação, nas ações "fora das instituições” demonstra uma rotinização aguda. Sem novos atores, novas táticas, novas energias teria o movimento sucumbido após a intensa institucionalização? Pelo jeito não. Uma incursão rápida ao ano 2012 rápida porque não faz parte do escopo temporal da tese - captou a introdução de uma tática "via instituições" nunca antes usada pelo Movimento Sanitário: a campanha para aumentar e garantir os recursos financeiros para o setor de saúde está sendo realizada com base no uso da Lei de Iniciativa Popular.

Na conclusão, retomamos os principais achados no que se refere às ações "via instituições", e também àquelas que o movimento usou "fora das instituições". Ressaltamos, por fim, as vantagens analíticas alcançadas com a ampliação do conceito de "repertórios de ação dos movimentos sociais" em termos de ação, atores e mobilização dos movimentos sociais. 


\section{Em busca do elo perdido: entre a Teoria dos Movimentos Sociais e as abordagens de Políticas Públicas}

No presente capítulo, em primeiro lugar, apresentaremos a Teoria dos Movimentos Sociais pelo prisma dos aspectos relacionados com a institucionalização, mostrando sua insuficiência para lidar com o nosso objeto de investigação. Em segundo lugar, explicitaremos por quê não adotamos as abordagens de Políticas Públicas e, no fim, exporemos o esquema analítico utilizado para a construção do objeto no qual aproveitamos algumas das categorias da Teoria dos Movimentos Sociais, fazendo adequações necessárias de modo a poder contemplar a atuação do Movimento Sanitário.

\subsection{Diálogo com as abordagens dos movimentos sociais}

Em 1996, alguns dos principais expoentes da Teoria dos Movimentos Sociais ${ }^{5}$ publicaram a coletânea Comparative Perspectives on Social Movements. Political Opportunities, Mobilizing Structure, and Cultural Framings, na qual propunham a atualização dos avanços teóricos e analíticos referentes às três vertentes utilizadas para analisar os movimentos sociais - oportunidades políticas, mobilização de estruturas e enquadramentos culturais -, bem como a sugestão de modos de articulálas. Dez anos depois, o livro foi reeditado. Isso indica que os seus principais pontos teóricos se mantêm atuais e podem ser aproveitados como base para a apresentação das ênfases e categorias de cada uma das três vertentes de análise, o que se pretende fazer adiante, complementando-a, quando necessário, com outras referências. A apresentação aqui empreendida não tem intuito de ser uma sistematização exaustiva

\footnotetext{
5 Nos ateremos às abordagens que se originaram nos Estados Unidos, porque, apesar das insuficiências, todas elas incluem o Estado e as instituições politicas como parte de seus arcabouços analíticos, diferentemente das abordagens de Novos Movimentos Sociais, que focam a sua análise exclusivamente na formação da identidade, pautando a definição do movimento nos seguintes elementos: a ação no campo da sociedade civil, a produção cultural, a busca da autonomia ou independência frente ao sistema político (Carlos, 2012: 37 e 41), o que sequer permite considerar o Movimento Sanitário como movimento social.
} 
das três abordagens, a qual pode ser encontrada alhures ${ }^{6}$, mas objetiva retratá-las de modo a tornar evidentes as suas insuficiências para tratar do Movimento Sanitário.

Embora haja a tendência de integração entre as três vertentes, a maior parte dos conceitos filia-se a uma ou outra abordagem. Com efeito, nesta tese, estabeleço um debate com a literatura, analisando cada uma das vertentes separadamente, apontando as principais categorias e atentando para as formas mediante as quais a institucionalização é abordada, extraindo as implicações para o estudo do movimento empírico e indicando quais categorias serão úteis na construção do objeto analítico. Para tanto, inicio com a análise da Teoria do Processo Político, da qual resgato os conceitos de "estrutura de oportunidades políticas" (EOP) e de "repertórios de confronto político", bem como enfatizo o de "institucionalização dos protestos". Em seguida, parto para a análise da Teoria da Mobilização de Recursos, na qual introduzo os sentidos da institucionalização das organizações dos movimentos sociais e entidades. Por fim, apresento a vertente do Enquadramento, mostrando que ela não aborda questões da institucionalização.

Na coletânea anteriormente mencionada, os autores dispensam o trabalho de erigir uma definição de movimentos sociais. Todavia, para alinhar a interpretação, valem-se de um punhado de exemplos empíricos das décadas de 1960 a 1980 que deixam claro para o leitor o fato de que os movimentos a que se referem são fenômenos de ação coletiva marcados por protestos, violência, rupturas institucionais ou, na colocação mais recente de dois outros importantes teóricos do campo, Tilly e Tarrow (2007), fenômenos de "confronto político" - como se pode ler já nas primeiras páginas do volume. Essa ênfase nas mobilizações em formato de protestos permeará as proposições das três abordagens. Como todos os caminhos levam a Roma, todas as proposições levam a (ou partem da) compreensão das mobilizações em formato de protesto.

Comecemos com a abordagem do Processo Político. Ela veio à luz na passagem dos anos 1970 a 1980, focando a conexão entre a política institucionalizada e os movimentos sociais, procurando entender o papel do sistema político mais amplo e as características políticas do Estado-Nação na emergência e nas variações 
dos movimentos em termos de estrutura, alcance e sucesso (McAdam; McCarthy; Zald, 2006: 2). Mais especificamente, a política institucionalizada foi conceituada em termos de estrutura de oportunidades políticas, na qual foram alinhavadas tanto as características formais do sistema político quanto a estrutura informal das relações de poder nele existente ${ }^{7}$. Ou na formulação de Gamson e Meyer (2006), os traços estáveis e voláteis do sistema político. $\mathrm{O}$ avanço em relação à abordagem que focava as organizações como a principal variável explicativa de mobilizações sociais, a de Mobilização de Recursos, em vigor na época, consistiu no fato de as instituições políticas passarem a ser consideradas como variáveis explicativas que permitiam entender o surgimento das mobilizações e os resultados de suas atividades (McAdam; 2006: 29). Um ciclo de protesto, nessa linha de raciocínio, poderia ser desencadeado por uma mudança ou uma série delas nos seguintes traços do regime político que compõem os elementos da estrutura de oportunidades políticas, conceito chave dessa abordagem: i) grau de abertura ou fechamento do sistema político; ii) estabilidade ou instabilidade dos alinhamentos das elites no interior do Estado; iii) presença ou ausência dos aliados no interior da elite; e iv) capacidade e propensão do Estado para repressão (McAdam, 2006: 27; Tilly, 2006: 44). ${ }^{8}$

Seguindo o raciocínio subjacente ao conceito da estrutura de oportunidades políticas, os movimentos promovem as suas primeiras mobilizações ao aproveitarem a mudança em uma ou mais dimensões da estrutura de oportunidades. Suas ações se tornam, desse modo, alvo de respostas do Estado, cujo teor de repressão ou aceitação varia segundo o tipo de regime, momento e contexto social. Nesse momento inicial, a(s) oportunidade(s) política(s) aparece $(\mathrm{m})$ independentemente da ação do movimento e por tempo limitado, e uma mudança no contexto político oferece a possibilidade para a emergência do movimento, o qual se consubstancia mediante protestos. O que diferenciaria a fase de desenvolvimento da fase de surgimento dos movimentos sociais é que as oportunidades e constrangimentos não seriam mais independentes

\footnotetext{
7 O texto de McAdam, que parte da preocupação com o alargamento do conceito de oportunidades políticas, faz uma sistematização do uso do conceito nas acepções de importantes pesquisadores do campo. Ver: McADAM, Doug. (2006).

8 Ainda constitui uma tarefa a ser realizada e um desafio da abordagem o estabelecimento da relação entre as dimensões da estrutura de oportunidades políticas e as feições do movimento a serem explicadas (McAdam; 2006: 31; Gamson; Meyer, 2006: 283).
} 
das ações dos movimentos. Como os autores o apontam: “The structure of political opportunities is now more a product of the interaction of the movement with its environment than a simples reflection of changes occuring elsewhere" (McAdam; McCarthy; Zald, 2006: 13).

Como seria enquadrada analítica e teoricamente esta nova relação dos movimentos sociais com as oportunidades? Os autores sugerem olhar para o próprio movimento, pois são os seus traços internos que podem responder pela sua capacidade de remodelar a paisagem política. Mais especificamente, apontam para o perfil organizacional dos grupos visto que "for the movement to survive, insurgentes must be able to create a more enduring organizational structure to sustain collective action" (McAdam; McCarthy; Zald, 2006: 13). Se o papel de influenciar o ambiente político, depois da fase de emergência, cabe a essas formas organizacionais do movimento, os autores não indicam quais seriam as formas de ação, afirmando apenas que os atores que surgiram na estrutura de oportunidades políticas possuem potencial especial para aproveitar essas oportunidades de maneira plena:

Those who temporarily benefit from the structure are apt to act agressively to take full advantage of the opportunities accorded to them. In doing so, they are likely to affect legislative or other forms of change that serve to restructure - in both intended and unintended ways - the legal and institutional or relational basis of the political system or both (McAdam, 2006: 37).

O máximo de esforço analítico feito para avançar essa questão é a indicação do potencial para ação e o seu caráter intencional e não pretendido, bem como as consequências previstas ou imprevistas. Em outro trecho da coletânea, no capítulo dedicado à sistematização crítica do processo político, McAdam (2006: 35) retoma a questão, afirmando que "o fazer" das oportunidades pelos movimentos não era uma tarefa amplamente assumida pelas pesquisas. O que está fora dos estudos, nas palavras do autor, é o "[...] the role that movements have played in reshaping the institutional structure and political alignments of a given polity"9 (2006: 36).

A estrutura de oportunidades políticas diz respeito ao que ocorre no âmbito de ação das autoridades, do governo ou dos detentores do poder. A contrapartida

\footnotetext{
${ }^{9}$ Algumas poucas exceções nesse sentido correspondem a raras evidências empíricas como "aberturas institucionais" e "rotinização e profissionalização de protestos" (McAdam; 2006: 36).
} 
analítica de tal estrutura na ação dos movimentos são as mobilizações, enquadradas no conceito de "repertórios de ação coletiva", cunhado por Tilly (1978). Em 2006, na obra Regimes e Repertórios, o conceito era definido pelo autor como "limited, familiar, historically created arrays of claim-making performance that under most circumstances greatly circumscribe the means by which people engage in contentious politics"(Tilly, 2006: vii) e rebatizado como "repertórios de confronto político".

A definição de repertórios de confronto político remete à ideia de limite: tratase de um conjunto limitado de formas à disposição dos atores coletivos na escolha da forma de ação. Tal dinâmica constrangida, apesar da novidade dos objetivos dos movimentos e da ousadia das reivindicações em relação ao status quo, é explicada pelo processo de aprendizagem e pela necessidade de comunicação efetiva. A ação precisa ser inteligível (familiar), tanto para aqueles que constituem seu alvo quanto para a sociedade em geral. No entanto, a ação não pode ser uma perfeita cópia dos episódios já ocorridos e conhecidos sob pena de deixar seus adeptos indiferentes e entediados. Portanto, um ingrediente de novidade, uma combinação inédita de elementos é requerida para assegurar a adesão e aumentar as chances de que sejam produzidos os resultados almejados. É inócua a inovação que não corresponder à capacidade da leitura por parte daquele a quem se destina a ação. Por exemplo, o sitin, estratégia tática amplamente utilizada pelo movimento de direitos civis nos Estados Unidos, nos anos 1960, mediante a qual se ocupava os lugares públicos, pacífica e estrategicamente, não faria sentido nenhum aos olhos da autoridade local na França do século XVIII, pois a ação coletiva ocorria em pequenas comunidades.

Como os atores são constrangidos a recorrer às formas disponíveis na sociedade, observa-se a variação dos repertórios: de lugar para lugar, de um tempo para outro e de uma relação para outra (Tilly, 2006: 35), por isso o conceito é formulado no plural. A França do século XVIII, o final do século XIX na América do Norte, o Brasil nas últimas décadas do século XX constituem contextos históricos e espaços que poderiam ser descritos mediante repertórios de confronto político com fortes variações. As variações podem ser radicais quando comparados, por exemplo, dois períodos na Europa ocidental e América do Norte: antes da segunda metade do século XIX e o século XX, e esta diferença consistiria no estilo paroquial, particular e comunitário das ações de confronto em oposição às formas cosmopolitas, modulares 
e autônomas (Tilly apud Tarrow, 1998: 31). Tomemos como exemplo os distintos conjuntos de ação utilizados pelos ativistas antinucleares na França e nos Estados Unidos: os primeiros usaram primordialmente as demonstrações nas ruas, porque o sistema político estava fechado, enquanto os segundos, além dos protestos, pressionaram a justiça e os partidos (Kitschelt apud Goodwin; Jasper, 2009: 252). Tal diferença indica que os elementos acionados do repertório podem variar de um lugar para outro em um mesmo período histórico.

Os repertórios aos quais se refere Tilly abrangem primordialmente ações de confronto político, que se revelam em fenômenos, tais como: as revoluções, as greves, as guerras, os movimentos sociais e os golpes (Tilly, 2006: 2). Mais especificamente, os "repertórios de confronto político" são compostos por um tipo de performance descontínuo, público e coletivo, conforme mostra o trecho a seguir: "Occasions on which people break with daily routines to concert their energies in publicly visible demands, complaints, attacks, or expression of support before returning to their private lives" (Tilly, 2006: 49). As coleções dos episódios de reivindicações públicas, coletivas e descontínuas constituem sua principal evidência, e o autor tem clareza de que esse foco acaba excluindo uma parte dos fatos: "Such an angle of vision obscure some important aspects of contentious politics: backroom deals, patron-client relations, organizing efforts that precede claim-making official response to claims, and interpretation by third parties." (Tilly, 2006: 49).

Repertórios de confronto político é um conceito amplo que engloba o de "repertório de ação dos movimentos sociais". Esse último se distingue pelo emprego de combinações das seguintes formas de ação política: marchas, comícios, procissões, demonstrações, ocupações, filas de grevistas, bloqueios, reuniões públicas, delegações, pronunciamentos para e na mídia, petições, cartas, panfletagens, lobby e criação de associações especializadas, coalizões ou frentes (Tilly, 2006: 182). A lista é finita e a organizamos analiticamente em um continuum que parte de formas mais ocasionais para padrões mais institucionalizados, são elas: o número dos participantes e sua visibilidade pública, os procedimentos mediados pelo uso da palavra em espaços mediáticos e públicos e, por fim, formas de ação institucionalizada - petições, lobby e criação de associações ou coalizões. A 
introdução dessas últimas formas não é problematizada em termos de institucionalização, tampouco é justificada analiticamente a sua inclusão "silenciosa".

A listagem de Tilly (2006) reflete o tratamento dispensado às formas institucionalizadas de ação entre os autores que trabalham com a abordagem do Processo Político: elas não são ignoradas, mas aparecem listadas sem que se lhes dispense alguma problematização analítica específica (Meyer; Tarrow, 1998: 26 e 23). O trecho abaixo, de dois autores que trabalham na abordagem do Processo Político, ilustra a ênfase nas formas não institucionalizadas, ainda que os autores reconheçam que o leque de ações seja mais amplo:

protest can encompass a wide variety of actions, ranging from conventional
strategies of political persuasion such a lobbying, voting, petitioning;
confrontational tactics such as marches, strikes, and demonstrations that
disrupt the day-to-day life of a community; violent acts that inflict material
and economic damage and loss of life; and cultural forms of political
expression such as rituals, spectacles, music, art, poetry, film, literature, and
culture practice of everyday life. [...] If there is a single element that
distinguishes social movements from other political actors, however, it is a
strategic use of novel, dramatic, unorthodox, and noninstitutionalized forms
of political expression to try to shape public opinion and put pressure on
those in position of authority [...] (Taylor; Van Dyke, 2007 263, grifos
nossos).

Os conceitos de estrutura de oportunidades políticas e de repertórios, quando decompostos analiticamente, mostram o lugar secundário que as ações institucionalizadas ocupam na vertente do Processo Político. No entanto, a institucionalização aparece como critério analítico forte em relação aos protestos. Quando esses são institucionalizados, tendem a acarretar a desmobilização dos movimentos, conforme mostraremos a seguir.

Na abordagem em foco, os autores remetem à dimensão "institucionalização" àquela forma de ação coletiva caracterizada por protestos surpreendentes, disruptivos ou violentos (Tilly, 2004; Meyer; Tarrow, 1998). Sua institucionalização ocorre quando os dois lados, isto é, os atores do movimento social e a autoridade pública, recorrem a um mesmo roteiro legal que indica o modo pelo qual a organização e a realização da atividade devem ser encaminhadas. Isso significa que o Estado passa a ter respostas convencionais, regulamentadas e institucionais, ao reagir e interagir com as atividades de mobilização dos movimentos sociais (Tilly, 2004; Meyer; Tarrow, 1998: 21). Trata-se de uma tendência observada no mundo inteiro, 
embora com diferenciações por regiões e países: os movimentos sociais têm adotado formas convencionais de protesto, despojadas de elementos de surpresa e ameaça ao status quo, razão pela qual os Estados os acolhem por meio de um conjunto de procedimentos institucionais (Tarrow, 2011). Se os protestos foram institucionalizados e seu uso se disseminou tanto entre os movimentos sociais, quanto entre outros atores sociais, questiona-se se os movimentos sociais - grupos que desafiam as autoridades (os challengers) - teriam ainda alguma forma efetiva de fazer suas reivindicações (Meyer; Tarrow, 1998: 26) e se poderiam ainda ser considerados movimentos sociais.

Os autores não dão sentença definitiva sobre a desmobilização, no entanto, quando os movimentos sociais recorrem ao protesto institucionalizado, o que constituiria uma forte tendência nos movimentos (Meyer; Tarrow, 1998), recebem a denominação específica de "movimentos contidos" (Tarrow, 2011). A rotinização do protesto significa que esse se torna previsível, isto é, plausível de ser tratado e enquadrado por normas e procedimentos existentes, o que compromete a sua forma disruptiva, bem como a sua capacidade de gerar resultados. Nesse sentido, a institucionalização significa, para esses autores, a ausência do elemento de inovação, que, como apresentamos, é parte do conceito de repertórios. Um grau de inovação garante o caráter de novidade e imprevisibilidade, atraindo novos adeptos e estimulando a participação dos antigos (Tilly, 2006). Ora, um movimento que se vale das ações institucionalizadas também poderia ser submetido ao exame do ponto de vista da inovação como critério de classificação e avaliação de sua condição de movimento. Isto é, talvez pudessem ser levantadas ressalvas quanto à pertinência do uso da categoria "movimentos sociais" para aqueles atores cujo repertório de ação perdesse qualquer capacidade de inovação, tornando-se inteiramente previsíveis nas formas de ação e nas demandas. Reservaremos o elemento de inovação para nossa tipificação no repertório de ação dos movimentos sociais.

Há quem tenha ido mais longe dentro da abordagem do Processo Político, contestando a ênfase nas formas não institucionalizadas como a expressão, por excelência, dos movimentos. Na introdução ao livro intitulado Estado, Partidos e Movimentos Sociais, Goldstone (2003) constata a identificação dos movimentos com os protestos como a principal chave de leitura da interação dos movimentos sociais com 
o Estado na teoria. Segundo o autor, isso teria sido decorrência da ênfase nos movimentos como challangers (na expressão cunhada por Tilly), isto é, como aqueles que querem entrar no mundo da política institucionalizada, tornando-se os seus membros reconhecidos. Uma vez distinguidos, deixariam sua condição de movimento para trás. Em outras palavras, visto que os instrumentos da ação política institucionalizada estariam à sua disposição, os movimentos abririam mão dos protestos. Goldstone refuta essa linha evolutiva, na qual se associa o início dos movimentos à fase dos protestos extrainstitucionais e o seu fim à sua incorporação à política institucionalizada convencional. O autor defende que há uma justaposição e interpenetração entre os atores e ações dos movimentos sociais e a política convencional, e também que ocorre uma complementaridade entre os protestos e a ação política convencional como o lobby, a participação em campanhas eleitorais e o voto (Goldstone, 2003: 7), que é aproveitada pelos atores dos movimentos. Os movimentos que mostram a insuficiência do foco da abordagem do Processo Político nos protestos são aqueles de classe média, como o movimento ambiental ou antiaborto, pois sempre utilizaram a variedade de ações que incluía, para além dos protestos, ações associativas e partidos políticos. A própria atuação das lideranças dos movimentos coloca em xeque o foco nos protestos na medida em que esses indivíduos atuam em duas ou mais frentes, como lideranças de movimentos e como candidatos políticos. Os protestos e a ação política convencional não são excludentes, afirma Goldstone. Com efeito, o autor propõe pensar os atores num continuum de influência e acesso ao Estado, no qual os movimentos se deslocam com certa rapidez, dependendo das mudanças no Estado e nos alinhamentos partidários.

Com as lentes de Goldstone, é possível incorporar ao repertório de ação dos movimentos sociais outros tipos de atuação, mas esses se restringem à política convencional, conforme indica o trecho a seguir: “[s]ocial movement activity and conventional political activity are diferent but parallel approaches to influencing political outcomes, often drawing on the same actors, targeting the same bodies, and seeking the same goals" (Goldstone, 2003: 8). A atuação como partido, sindicato ou grupo de interesse ou por meio do voto eleitoral pode ser considerada como parte das táticas dos atores sem que seja necessário abandonar o conceito de "movimento social" como categoria de análise e suas proposições. Duas consequências derivam 
do argumento de Goldstone: de acordo com a primeira, ao abrir o leque de atuação, o autor foi obrigado a diversificar a reação do Estado para além da repressão ou da sua falta, mas com isso o congelou como categoria analítica separada, mantendo os movimentos fora das suas fronteiras. Esse ângulo impede de ver aqueles episódios nos quais os atores do movimento rompem a barreira entre eles como outsiders e challengers, e conquistam para si espaços de influência. A captação desses instantes é impedida também - e essa é a segunda consequência - pela restrição às formas de atuação da política convencional, que não levam em consideração as formas inovadoras. Esse foco foi melhor trabalhado por Guigni e Passy (1998), que propuseram explicitamente a ampliação do conceito de repertório de ação dos movimentos sociais.

Os autores cunharam um novo conceito, o de "repertório de cooperação conflituosa", incorporando a cooperação como condição possível das relações entre os movimentos e o Estado. O ponto de partida do seu argumento é a restrita preocupação da literatura de movimentos sociais com as formas de interação nas quais os movimentos sociais não se colocam em franca oposição ao Estado, mas cooperam com ele. A insuficiência analítica da categoria de repertórios de confronto político é justificada pelas mudanças na sociedade. O Estado moderno teria perdido a capacidade de "pilotar" a sociedade, à medida que se tornou demasiadamente complexa. Assim, os atores da sociedade civil passaram a desempenhar um papel importante no processo da regulação, que não consiste apenas em confrontos. Pelo contrário, há cooperação na medida em que os movimentos, em busca de resultados efetivos, batem na porta do Estado e o Estado também os procura, especialmente em função da falta de conhecimento e informação para resolver os problemas.

As ações de caráter cooperativo, ainda que permeadas pelo conflito, fazem realçar novas formas de institucionalização que não perfazem os caminhos de outros atores políticos institucionalizados. ${ }^{10}$ Os autores argumentam que "[...] certain

\footnotetext{
${ }^{10}$ A inclusão dos movimentos sociais nos processos decisórios no Estado é também tratada por Dryzek et al. no livro Green States and Social Movements, no qual os autores analisam os movimentos ambientalistas que, como o Movimento Sanitário, usam em abundância o repertório de ação nas instituições. No entanto, à semelhança dos principais teóricos, colocam uma carga normativa sobre a inclusão, apontando que ela compromete o "caráter de movimento social dos grupos" (Dryzek, 2003: 82).
} 
contemporary movements are following path of incorporation in state structure that is nevertheless qualitatively different from the traditional path of institutionalization followed by labor movement" (Giugni; Passy, 1998: 83). Como instâncias analíticas de observação do processo da cooperação conflituosa, indicam as arenas e etapas do processo político de tomada de decisão: i) arena legislativa e processo de tomada de decisão; ii) arena administrativa e processo regulatório (que não inclua atividades legislativas); iii) processo da implementação, no qual podem ocorrer três tipos de ação cooperativa: consulta, integração (participação na decisão) e delegação.

Guigni e Passy (1998) não deram continuidade ao desenvolvimento teórico e analítico do repertório de cooperação conflituosa. Porém, mais de uma década depois, um trabalho brasileiro propôs-se a especificar o conceito de repertório para além dos protestos (Abers; Serafim; Tatagiba, 2011). As autoras desse trabalho também refutam o foco exclusivo no conflito extrainstitucional, uma ênfase que não daria conta da maior parte da atuação dos movimentos sociais no Brasil, pois “[...] o caso brasileiro desafia essa asserção pela contínua atuação dos movimentos no interior do Estado" (Abers; Serafim; Tatagiba, 2011: 8). Em comparação a Guigni e Passy, a sua especificação dos "repertórios de interação" repousa no destaque às categorias empíricas, incluindo lobby no parlamento, participação institucional, política de proximidade e ocupação de cargos em governos.

Desse modo, um conjunto de autores do Processo Político tem apontado como insuficiente a restrição da categoria de repertório de ação dos movimentos sociais aos protestos como a lente capaz de ler todos os movimentos, ainda que seus postulados não tenham chegado a marcar de forma decisiva o debate, a julgar pela própria coletânea na qual baseamos nossa discussão das vertentes. Advoga a favor da inclusão, cada qual à sua maneira, das formas de ação institucionalizadas no repertório dos movimentos sociais. Goldstone (2003) defendeu as formas convencionais; Guigny e Passy (1998) enfatizaram as formas inovadoras; a proposta brasileira de Abers, Serafim e Tatagiba (2011) mantiveram-se entre as posições anteriores. Concretamente, a especificação do repertório de ação institucionalizada dos movimentos sociais inclui: $i$ ) as formas convencionais como lobby, atuação como partido e/ou sindicato, ocupação de cargos em governos ii) formas não convencionais como participação institucional (integração e consulta, no caso de 
Guigny e Passy) e delegação. Esta lista constitui um guia analítico útil na medida em que o Movimento Sanitário não recorreu a protestos como sua principal forma de ação.

Em síntese, a abordagem do Processo Político restringe a reflexão analítica da institucionalização a protestos, apontando nesse tipo de institucionalização efeitos desmobilizadores. Ainda assim, o conceito de repertório de ação dos movimentos sociais instrumentaliza de forma interessante a análise, chamando a atenção para os elementos de reprodução e inovação. Desse modo, para construir o nosso objeto analítico, aproveitaremos o conceito de repertório de ação junto ao de estrutura de oportunidades políticas, o que será apresentado na seção seguinte. Por enquanto, avancemos na discussão da próxima vertente, a de "Mobilização de Recursos".

Conforme vimos, após a emergência do movimento social, os desdobramentos das interações entre os movimentos e a estrutura de oportunidades políticas são considerados pelo prisma das organizações dos movimentos (McAdam; McCarthy; Zald, 2006: 13). Tal perspectiva constituiu o objeto preferencial da segunda abordagem discutida aqui, a saber, a abordagem de Mobilização de Recursos, marcada pelo artigo seminal de Zald e McCarthy (1977). Nesse trabalho, os autores contestavam a visão vigente na época de movimentos como irrupções irracionais de multidões descontentes, mostrando, por sua vez, que havia uma retaguarda de organizações sólidas e formais amparando as mobilizações. Nos debates iniciais, havia uma polarização entre aqueles que defendiam a importância das organizações formais e aqueles que enxergavam nas conformações menos instituídas, como redes no trabalho e bairro, o papel crítico na facilitação e estruturação da ação coletiva de movimentos sociais (McAdam, 2006: 4). Aos primeiros, também se opunham os adeptos da democracia participativa da nova esquerda estadunidense, os quais abominavam as organizações formais, considerando-as como antíteses das mobilizações efetivas (Clemens; Minkoff, 2004: 155). Seja como for, as formas organizacionais eram estudadas como recursos necessários para as mobilizações.

Passados mais de 25 anos (McCarthy, 2006), a abordagem de Mobilização de Recursos incorporou em suas proposições todas as formas organizacionais e estruturas que facilitam a ação coletiva de movimentos sociais. A categorização, a tipificação e o mapeamento desse universo, agora bem mais amplo, são distribuídos 
ao longo do eixo analítico que vai das expressões informais às mais formais. Num extremo, aparecem as famílias e as redes de amigos como "contextos de micromobilização", isto é, locais do dia a dia nos quais os laços podem se tornar "solidarity and comunication facilitating structures when and if they choose to go into dissent together" (McCarthy, 2006: 142). No outro extremo, há organizações formalizadas, burocratizadas e profissionalizadas. O mapeamento das formas constitui um passo necessário para agregá-las em configurações de mobilização estrutural (mobilizing structural configurations) de modo a viabilizar as comparações entre diversos sistemas políticos ou entre os movimentos no interior de um mesmo sistema. As configurações constituem um avanço analítico que supera a fase da mera descrição, ainda que sua função seja igual, a saber: entender as rotinas dos movimentos e sua relação com as estruturas de oportunidades políticas e os processos de enquadramentos (McCarthy, 2006: 141).

Como é possível depreender da última frase, a abordagem de Mobilização de Recursos é aparentemente menos autônoma e independente da do Processo Político. Se possui um arcabouço próprio de categorias e proposições, sua contribuição específica consiste em dissecar as organizações como meios que possibilitam a mobilização de movimentos sociais (Clemens; Monkoff, 2004: 156). Essa ressalva é importante para entender a razão pela qual os mesmos autores da abordagem anterior serão mobilizados na compreensão das proposições a respeito da institucionalização ${ }^{11}$ das organizações dos movimentos sociais.

A institucionalização das organizações compreende analiticamente a dinâmica interna das entidades, bem como as implicações dos processos de formalização e especialização nas causas do movimento e de profissionalização dos empreendedores do movimento. A montagem da "estrutura formal" em torno dos grupos de pessoas que costumavam agir de modo informal e ad hoc para a realização de mobilizações consiste na aquisição do status jurídico e do contrato social a partir dos quais são estabelecidas as normas e as regras do funcionamento da organização. Se já havia

${ }^{11}$ A institucionalização não é o único caminho possível a ser percorrido pelas organizações do movimento depois dos subsequentes ciclos de mobilizações. Há mais três alternativas: a comercialização (constituição de provedoras de serviços ou produtos), a radicalização (criação de restritos grupos de extrema violência) ou ainda, a involução (criação de grupos de autoajuda ou clubes). (Kriesi, 1996 apud Tilly; Tarrow, 2007: 129-131). 
uma organização formalizada, a institucionalização refere-se ao direcionamento das atividades da entidade exclusivamente para as finalidades do movimento. Em ambos os casos, a especialização é o objetivo e o resultado.

A formalização e a especialização levam à profissionalização dos quadros da organização, que, na visão da literatura, acaba criando uma burocracia, cujo comportamento é semelhante ao das oligarquias das grandes organizações descritas por Michels (Tilly, 2004: 156; Meyer; Tarrow, 1998 15). O comportamento das oligarquias, segundo o autor, resulta na disjunção dos interesses entre as lideranças dos grupos e seus membros; noutros termos, na "lei de ferro da oligarquia". Ao favorecer e defender visão e objetivos próprios, a partir de uma posição privilegiada, os profissionais burocratizados tenderiam a fechar os canais para aqueles que não fazem parte do establishment do movimento social. Com isso, poderia ser observada a diminuição dos incentivos para a entrada de novos temas, táticas e reivindicações. Desse modo, os movimentos deixariam de funcionar como amplos canais para as demandas associadas ou ligadas a amplos segmentos da população (Tilly, 2004: 150; Tarrow, 2011; Meyer; Tarrow, 1998: 15). A profissionalização dos quadros das organizações dos movimentos implicaria também, pela necessidade de dedicação às causas, o aumento dos custos e a diminuição das oportunidades de participação daqueles que não dispõem de recursos necessários.

A formalização da estrutura organizacional, a especialização nas causas do movimento e a profissionalização dos quadros obrigam as entidades a procurar fontes de recursos estáveis que garantam suas atividades, mas que podem cooptá-las. Se os recursos não puderem ser providos pelos apoiadores ou associados do movimento e, com isso, a entidade tiver de recorrer a outras organizações ou ao Estado, sua atuação em termos de radicalidade das causas pode ser comprometida. Trata-se de um mecanismo de cooptação na acepção dos autores norte-americanos Meyer e Tarrow (1998: 21) que resulta na conformação da atuação de acordo com os patrocinadores do movimento. Se o patrocinador for o Estado, poderia ser esperada a diminuição dos protestos e contestações e, com isso, os esvaziamentos das fileiras do movimento, como também o fim das mobilizações.

É importante destacar aqui que o desdobramento analítico da institucionalização das organizações também leva os autores a compreenderem a 
desmobilização dos movimentos e o possível fim dos mesmos como o seu resultado. Quando as organizações já estão institucionalizadas (formalizadas, profissionalizadas e com fontes de recursos estáveis), mostrando-se capazes de ter acesso a importantes instituições políticas e de aderir às rotinas estabelecidas que lhes garantam a participação em negociações nas principais instituições, a atuação delas não pertence mais, na visão dos autores, ao movimento social. Com efeito, ocorreria uma última transformação a partir da qual as organizações deixariam de ser (parte de) movimento social ao assumirem uma das formas de ação institucionalizada, tais como, grupo de interesse, partido ou sindicato (Meyer; Tarrow, 1998) O "movimento" feminista norte-americano teria atravessado essas etapas da institucionalização: hoje, já desmobilizado, seria composto por grandes organizações burocráticas com profissionais remunerados, cujas táticas e formas de interação se assemelhariam às práticas utilizadas por lobbies profissionais e grupos de interesse (Tarrow, 1998: 101 e 208; Tilly; Tarrow, 2007).

O cerne da problematização analítico-teórica da Mobilização de Recursos assenta-se na visão da organização como recurso necessário para a mobilização: sua institucionalização num primeiro momento traz benefícios para a mobilização, ainda que suas consequências sejam negativas para a capacidade de mobilização a longo prazo. O que permanece exterior à perspectiva da institucionalização das organizações são as ações institucionalizadas realizadas por meio dessas organizações com o Estado, conforme aponta Clemens (1993). Essa autora faz parte de uma nova geração de pesquisadores que rediscutem o papel das organizações dos movimentos sociais, questionando tanto a validade das tendências conservadoras contidas nas proposições relativas às organizações, como burocratização ou oligarquização, quanto à interpretação das formas organizacionais restrita à sua presença ou ausência, no sentido de facilitar ou bloquear a mobilização dos movimentos.

Essa nova literatura ${ }^{12}$ abandona o tratamento das organizações como recurso e sugere em seu lugar tratá-las como distintas culturas de interação capazes de moldar 
a trajetória da mobilização. A pergunta "como devemos nos organizar?" ganha centralidade e mostra-se prenhe em consequências para o desenvolvimento da ação política organizada (Clemens; Minkoff, 2004). Nessa perspectiva, ressalta-se a diversidade das organizações, centrando a análise, em primeiro lugar, na interação entre elas como meio de construir os vínculos de pertencimento e, nesse sentido, aponta que a institucionalização das organizações não conduz necessariamente à supressão do engajamento e da participação. Pelo contrário, a interação entre as organizações poderia gerar novas mobilizações (Clemens; Minkoff, 2004).

Em segundo lugar - isso nos interessa em particular -, destaca-se o uso político das organizações dos movimentos sociais ou, em outras palavras, o uso do arsenal associativo como instrumento ou canal de fazer política, é destacado, e não como recurso para protestos (Clemens, 1993). A organização ou conjunto delas podem vir a se tornar uma forma institucional por meio da qual os atores agem politicamente sem recorrer, como querem os principais expoentes da Teoria dos Movimentos Sociais, às formas dos atores já institucionalizados. Com base no caso do movimento de mulheres norte-americanas, na passagem do século XIX para o XX, Clemens (1993) mostra como as atrizes do movimento aproveitaram os modelos organizacionais não políticos para objetivos políticos, valendo-se para tanto de uma variedade de formas - clubes, corporações, sindicatos etc. - que se articulavam de diferentes modos com as instituições políticas existentes. Com isso, contribuíram para uma importante mudança institucional na história política dos Estados Unidos que consistiu na introdução da atividade de lobby (Clemens, 1993: 757). A invenção do lobby teria sido possível em função da posição marginal do movimento no sistema político e da exclusão das mulheres do sistema eleitoral, conforme o sintetiza a autora no trecho a seguir:

While internal struggles and electoral tactics were central forces in the decline of the parties and the preeminent position of electoral politics (McGerr 1986; Shefter 1983) voluntary associations played a key role in

Cambridge University Press; Polletta, Francesca (2002) Freedom Is an Endless Meeting: Democracy in American Social Movements. Chicago: University of Chicago Press; Moore, Kelly and Nicole Hala (2002) "Organizaing Identity: The Creation of science for the People". In: Micheal Lounsbury and Marc Ventresca (eds.) Research in the Sociology of Organizations: Enterpreneurs, Organizations, and Social Changes, 19, 309-35 e Stevens, Mitchell (2001) Kingdom of Children: Culture and Controversy in the Homeschooling Movement. Princeton, NJ: Princeton University Press. 
elaborating a new style of politics focused on specific issues, interests, and legislative responses (Clemens, 1993: 757).

A segunda possibilidade analítica do uso das organizações diz respeito, portanto, ao engendramento de (novas) formas de ação política, as quais dependem do formato organizacional assumido. A escolha de uma ou outra forma organizacional não é aleatória nem mecânica; os atores escolhem a partir das formas organizacionais que estão à sua disposição, e seu uso pode ser inovador e surpreendente (Clemens; Minkoff, 2004). Esta mudança no tratamento das organizações ganha um aporte analítico com o conceito de "repertório organizacional", cunhado por Clemens (1993), inspirado no termo análogo repertório de ação coletiva, de Tilly, apresentado em 1978. Tal conceito ressalta a historicidade das formas, a existência de conjuntos delimitados e, consequentemente, a sua reprodução pelos atores do movimentos sociais. Com o deslocamento do recurso à ação proposto por Clemens, a escolha do formato organizacional apresenta-se como parte do repertório de ação dos movimentos sociais e será aproveitado nesse sentido na análise do nosso objeto empírico.

Na discussão das principais abordagens teóricas dos movimentos sociais, resta a análise da vertente Processos de Enquadramento (framing processes), a mais recente das três. Com base nos trabalhos de Erving Goffmann, foram desenvolvidos conceitos para mostrar como símbolos e ideologias são utilizados em movimentos sociais (Zald, 2006), o que veio a preencher a lacuna deixada pelas ênfases dos estudos pautados em estruturas de oportunidades políticas e mobilização de recursos em termos da cultura e, mais especificamente, introduzir a questão da identidade, a qual constituía o foco central das abordagens de Novos Movimentos Sociais (Alonso, 2009). A vertente de Enquadramento incorporava as oportunidades políticas e os recursos como condições necessárias, alegando, todavia, sua insuficiência para explicar a emergência da ação coletiva dos movimentos sociais. "Enquadramentos de ação coletiva" (frames) são definidos como conjuntos de crenças e sentidos orientados para a ação, os quais inspiram e legitimam as atividades e as campanhas do movimento social (Benford; Snow, 2000: 614). Esses enquadramentos são produzidos e reproduzidos no interior de processos denominados framing e 
constituem, ao lado da análise dos enquadramentos, o segundo objeto analítico daqueles que constroem e buscam ampliar o alcance da abordagem.

Do ponto de vista de sua função para a ação, o enquadramento de ação coletiva possui três componentes: o diagnóstico, o prognóstico e a parte motivacional. O diagnóstico implica a identificação do problema, não raramente enquadrando-o em termos de injustiça, e a ele é atribuída uma causa (situação e/ou agente). O prognóstico envolve a proposta de solução para o problema em termos de um plano de ação ou estratégia. A terceira parte, a motivacional, fornece instrumental para engajar os integrantes do movimento na ação coletiva, o que inclui a criação de um vocabulário específico (Benford; Snow, 2000: 617). Se as tipologias de enquadramentos de ação coletiva não têm trazido grandes ganhos analíticos, os processos nos quais são produzidos aportam mais potencial de problematizações e explicações. Os autores distinguem dois principais componentes do framing, fenômeno processual, sejam esses, a "agência", que consiste no trabalho de ativistas e organizações de fazer e refazer constantemente os enquadramentos, e a "contestação", porque os enquadramentos são construídos na diferença com os outros - e não raramente os desafiam¹3.

Os enquadramentos são criados em três ordens de processos mais específicos. O conceito de "processos discursivos", ainda pouco estudado por se pautar em exaustivos estudos etnográficos, chama a atenção para a construção dos enquadramentos de ação coletiva durante os encontros e as mobilizações, nos cursos de interação entre os indivíduos. $\mathrm{O}$ segundo conjunto, que é mais explorado no interior da abordagem (McAdam; McCarthy; Zald, 2006: 6), refere-se aos processos estratégicos conduzidos pelas lideranças do movimento, realçando o caráter deliberativo e utilitário dos enquadramentos utilizados para resultados específicos (por exemplo, ganhar novos membros ou conquistar recursos). Esses processos são definidos como "conscious stratategic efforts by groups of people to fashion shared understanding of the world and of themselves that legitimate and motivate collective actions" (McAdam; McCarthy; Zald, 2006: 6). Por fim, o terceiro tipo de processo é o da contestação, no qual a elaboração dos enquadramentos da ação coletiva constitui-

13 Para o apanhado geral e extenso sobre os desdobramentos analíticos do framing e frentes de trabalho de acordo com seu estágio de desenvolvimento, ver o texto de Benford e Snow (2000). 
se nas relações de oposição contra aqueles que tentam destruir ou deslegitimar o enquadramento do movimento. Nesse tipo, a observação se desloca para a relação do movimento com a mídia e para aquelas estabelecidas no interior do movimento.

$\mathrm{Na}$ abordagem em foco, a questão da institucionalização não se coloca de forma explícita: não há menção a ela nos três processos de produção de enquadramentos, e a relação do enquadramento com as oportunidades políticas é trabalhada no sentido de considerá-las como seu componente, ou seja, como decisão estratégica dos atores de interpretar um dado momento do contexto político como oportunidade e inseri-lo no frame (Benford; Snow, 2000: 631), o que corresponde ao postulado de que as oportunidades não existem se não são percebidas como tais pelos atores.

Se, na tarefa maior de compreender o caráter e percurso dos movimentos sociais, a abordagem de framing pode somar-se às do Processo Político e da Mobilização de Recursos (Benford e Snow, 2000: 612), os processos de produção dos enquadramentos de ação coletiva têm sido aproveitados mais especificamente para explicar os níveis micro e médio de mobilização, o recrutamento e a participação, e como um dos mecanismos capazes de esclarecer a relação entre a identidade individual e a coletiva. Embora recente, o desenvolvimento desse arcabouço teóricoanalítico tem aberto novas frentes de trabalho, conforme mostram Benford e Snow (2000), mas esse mesmo ferramental também tem auxiliado as análises daqueles que não fazem do frame de ação coletiva, nem do framing, o ponto central do trabalho. De forma pouco onerosa, oferece uma chave de leitura dos documentos por meio dos quais os atores dos movimentos manifestam suas propostas e chama a atenção para a sua importância como norte para a ação. Um dos três processos supramencionados da criação dos enquadramentos, o estratégico, mostra que esses legitimam e motivam as mobilizações de protesto, o que pode ocorrer também no caso de ações institucionalizadas. Textos com diagnóstico e prognóstico claros e amplamente divulgados podem ganhar um peso relevante, representando o movimento muito além das suas mobilizações. Os frames, nesse sentido, prolongam no tempo o efeito das mobilizações do movimento, à medida que as debatem, compartilham e legitimam, permitindo que, como um produto do coletivo, seja utilizado, mesmo quando a mobilização já terminou. 
O enquadramento coletivo não pode ser confundido com a identidade coletiva, mas contribui para ela, sendo uma forma da conexão entre identidade individual e coletiva. Segundo Benford e Snow (2000), essa conexão ocorre de duas formas. Os enquadramentos situam os atores no tempo e espaço na condição de portadores de características que implicam dado tipo de relação e linhas de ação atreladas, pois, na sua estruturação, apresentam-se de modo claro (algo como, "quem somos nós em relação aos outros" e "como queremos agir para mudar o status quo"). Essa percepção ocorre no nível individual, mas estabelece a conexão com o coletivo desenhado no frame. A segunda conexão se processa em atividades coletivas relacionadas com o frame, como a elaboração dos mais diversos documentos do movimento, os pronunciamentos na imprensa e as conversas envolvendo a identidade do movimento.

As proposições da abordagem de Enquadramento introduzem a ideia de identidade coletiva, mas ainda de forma bastante modesta, focando a percepção individual e a relação entre as lideranças. Isso significa que seria possível identificála, mas por meio de estudos muito específicos relacionados à produção dos enquadramentos, que não constituem o propósito deste trabalho. Essa limitação nos levou a procurar uma definição mais ousada, capaz de instrumentalizar a análise na identificação de vínculos sem exigir, para tanto, um estudo exaustivo. Encontramos essa possibilidade na proposta de Melucci (1996) para quem a construção da "identidade coletiva" se configura como problema central e realça nesse processo a importância da definição compartilhada, semelhante ao frame, bem como o processo da sua produção e reprodução na ativação constante das relações.

A identidade coletiva é definida por Melucci (1996) como "an interactive and shared definition produced by a number of individuals (or groups at a more complex level) concerning the orientations of their action and the field of opportunities and constraints in which such action is to take place" (Melucci, 1996: 70). Enquanto "definição compartilhada", a identidade possui uma parte estática e delimitada que se manifesta externamente como algo coeso e unificado, ainda que seja fruto de "exchanges, negotiation, decision, and conflicts, constantly activated by actors but not apparent on the surface. These processes are not immediately visible, since the actor tend to conceal themselves and their fragmentation" (Melucci, 1996: 383). A 
unidade externa e o processo de sua elaboração correspondem a dois elementos da abordagem de Enquadramento, frame e framing (Benford; Snow, 2000), ambos de fácil identificação em termos de evidências empíricas. Melucci avança as considerações para além dessas duas instâncias analíticas, buscando compreender de que forma o sentimento de pertencimento se reproduz entre os atores de movimentos. Para tanto, frisa que a identidade coletiva precisa ser recorrentemente reconstruída, o que se processa por meio das "relações ativas" ou "relações ativadas". A identidade não é um dado natural, mas uma representação forjada que, uma vez construída, precisa ser realimentada sob pena de deixar de existir. Com efeito, é necessário que haja um sistema de ação no qual as relações que vinculam os atores sejam ativadas (Melucci, 1996: 70). A essencialização, naturalização ou reificação da identidade são justamente impedidas pelo postulado do conceito segundo o qual a identidade coletiva se constrói e reconstrói mediante "relacionamentos ativos" (active relationships), nos quais os atores interagem, comunicam-se, negociam, influenciam uns aos outros e tomam decisões. Isso implica a existência de pontos de encontro nos quais são elaboradas as estratégias comuns, como também conduzidas as atividades voltadas para as finalidades do movimento e nas quais os atores atuam juntos. Nesse sistema de ação são geradas novas definições, "by integrating the past and the emerging elements of the present into the unity and continuity of a collective actor" (Melucci, 1996: 75).

A identidade coletiva nos termos meluccianos contém, no processo de sua produção, a ideia forte de "mudança", mas também a de "permanência", as quais sugerem a construção das formas institucionalizadas relacionadas com a identidade. A permanência é um dos traços básicos de qualquer identidade ${ }^{14}$, na medida em que prevê a continuidade do sujeito de ação a despeito das variações no tempo e das suas adaptações ao ambiente (Melucci, 1996: 71). Há tendência e necessidade de estabilizar a identidade e dar a ela uma forma mais permanente. Os contínuos investimentos necessários nesse sentido cristalizam-se em formas organizativas, sistema de regras e relações de liderança. Como exemplos de tais esforços constantes, poderiam ser mencionados os marcos históricos, isto é, a realização de eventos

${ }^{14}$ Outros dois traços são a delimitação do sujeito em relação aos outros, baseada na habilidade de autorreconhecimento, e a possibilidade de ser reconhecido. 
regulares que se tornam tradicionais a criação de associações que explicitam frentes de lutas do movimento ou ainda as publicações. As formas relativamente permanentes e institucionalizadas ocultam o processo de (re)construção permanente da identidade coletiva. Cabe, então, uma análise que consiga articular ambas as dimensões: de um lado, as formas de produção da identidade que exigem dinamismo, atuação e são continuamente repostas; e, de outro, as formas cristalizadas de identidade e que permanecem ao longo do tempo. Melucci (1996) indica a tensão entre a permanência e a mudança, porque em cada uma delas há um germe de destruição da identidade coletiva: a permanência pode congelar e tornar distante a experiência vivida, como também a mudança rápida e constante demais é capaz de eliminar os elementos necessários do passado ${ }^{15}$.

O conceito da identidade coletiva de Melucci (1996), ao frisar a permanência e a mudança, direciona a lente de análise para instâncias empíricas que podem captar esses dois processos constitutivos da identidade. Uma vez iluminados, compreendese os meios pelos quais o vínculo entre os integrantes e o movimento pode ser reativado. A ativação constante das relações e certo grau de institucionalização da identidade coletiva constituem dois aspectos analíticos importantes à mão do analista quando busca entender como a identidade coletiva do movimento social se reproduz ao longo do tempo.

Da discussão feita até aqui, retemos para a construção do nosso objeto analítico: i) o diagnóstico e o prognóstico como formas de descrever a percepção da estrutura de oportunidades políticas pelo movimento social; ii) o conceito de repertório de ação dos movimentos sociais com o pressuposto de que os atores recorrem às formas já existentes, incrementando-as, às vezes, com um elemento de inovação; e iii) a identidade coletiva composta por definição compartilhada e processo de relações ativadas. Essas categorias serão rediscutidas na seção intitulada "Construção do objeto analítico".

\footnotetext{
${ }^{15}$ Melucci se refere ainda a certo grau de investimento emocional que também é responsável para que os indivíduos se sintam parte da unidade comum (Melucci, 1996: 71). A identidade coletiva, afirma Melucci, nunca é inteiramente negociável, porque a participação na ação coletiva possui um sentido que não pode ser reduzido a um cálculo de custo-benefício. Nas palavras do autor: "There is no cognition without feeling and no meaning without emotion" (Melucci, 1996: 71).
} 
Vamos agora colocar as lentes analíticas das abordagens acima discutidas para ler o Movimento Sanitário, o qual será denominado, mais tarde, movimento pela Reforma Sanitária. No final de 1979, já era possível identificar algumas organizações que se colocavam em oposição ao sistema de saúde em vigência - caracterizado por eles como "privatizante", "excludente", "hospitalocêntrico" e "curativo" -, e reivindicavam sua mudança radical para um sistema "universal", "gratuito", "integral" e "preventivo". Havia o Centro Brasileiro de Estudos de Saúde (Cebes), cuja fundação pelos jovens sanitaristas foi acompanhada pelo lançamento da revista Saúde em Debate, que se tornou um importante veículo de difusão das ideias e propostas do movimento em vários estados do país (Paula et al., 2009; Escorel, 1998). A Associação Nacional dos Médicos Residentes (ANMR), constituída pelos residentes dos Departamentos de Medicina Preventiva do Rio de Janeiro e São Paulo que forneceram as concepções teóricas do movimento a respeito da saúde pública, promovia greves e campanhas. Tais mobilizações, embora empenhadas em causas da categoria médica, evidenciavam as teses do movimento, as quais eram difundidas nas cartas inflamadas circulantes nos encontros e congressos. A Associação Brasileira de Pós-Graduação de Saúde Coletiva (Abrasco), fundada em 1979, incluía, por sua vez, em suas atividades a luta por uma nova área no setor de saúde, a saúde coletiva. Essa área seria portadora de uma proposta de mudanças políticas e de um novo modo de olhar para a questão de saúde no país (Belisário, 2002). As ideias do movimento e seus militantes circulavam, sob a denominação de Renovação Médica, também pelos sindicatos dos médicos.

Os integrantes dessas organizações reuniram-se, no final de 1979, em uma primeira grande mobilização do movimento, na qual compareceram mais de 800 pessoas, discutindo e compartilhando um diagnóstico comum sobre a situação do país e do setor de saúde, bem como um projeto de mudanças. O 1o Simpósio de Política Nacional de Saúde, cuja anfitriã foi a Comissão de Saúde do Congresso Nacional, foi realizado na Câmara dos Deputados. O coletivo adotou como um documento-síntese do evento o texto intitulado “A Questão Democrática na Área da Saúde", elaborado pelo Cebes. Nesse documento, o regime autoritário era claramente identificado como responsável pela política privatizante, empresarial e concentradora de renda, marginalizando cerca de $70 \%$ da população dos benefícios 
materiais e culturais do crescimento econômico (Cebes, 1979). Como denominar em categorias da Teoria dos Movimentos Sociais esse evento? Seria um protesto institucionalizado no interior da instituição política? Ou seria expressão do lobbying?

Alguns anos depois, já no final da fase da transição democrática, entre 19851988, as mesmas entidades continuavam atuantes, com exceção da ANMR, que deixou de se posicionar politicamente. Surgiu a Plenária Nacional de Saúde, que agregava dezenas de organizações dos níveis estadual e municipal, convocada para acompanhar e influenciar o processo da Constituinte. Ela promovia as mobilizações na própria Câmara dos Deputados, pressionando congressistas, comissões, relatores etc. O Movimento Sanitário atingiu seu ápice de mobilização e expressão pública com a 8a Conferência Nacional de Saúde, em 1986, que se tornou um marco histórico, ainda que tivesse sido realizada no espaço tecnocrático e da burocracia estatal. Uma vez que a Conferência fora convocada pelo ministro da saúde e financiada com os recursos do Estado, poderia ser classificada como protesto institucionalizado?

Nessa mesma época, vários ativistas do movimento estavam em cargos de poder no Estado, colocando em prática a estratégia de caminho institucional adotada desde os anos 1970. Aqueles que assumiam as secretarias municipais de saúde constituíram, em 1987, o Conselho Nacional de Secretarias Municipais de Saúde (Conasems), organização conduzida pelos militantes do movimento, que estavam na condição de secretários municipais de saúde. Desse modo, o Conasems é claramente reconhecido como entidade híbrida ("meio Estado, meio sociedade"). Esse aspecto também foge dos termos relacionados com a institucionalização de organizações.

Esses quadros apresentados mostram como a atuação do Movimento Sanitário escapa aos aspectos da institucionalização mais frequentemente trabalhados na teoria, a saber, a institucionalização dos protestos e a das organizações do movimento. A lacuna que o Movimento Sanitário aponta na Teoria dos Movimentos Sociais levanta também a seguinte questão: essa teoria seria a melhor forma de enquadramento teórico? De um lado, a diversidade das formas de ação, a heterogeneidade dos grupos e as suas procedências, como também a variedade de temáticas que se cruzam e se articulam num sem-fim de eventos, mas sob a mesma bandeira da reivindicação do acesso universal e gratuito à saúde - que se tem reproduzido ao longo dos últimos trinta anos -, torna o recurso à Teoria dos 
Movimentos Sociais algo natural. De outro lado, o emprego de conceitos como "comunidade de especialistas" (Kingdon, 1995), "coalizões de defesa" (Sabatier; Weible, 2007), “domínios de políticas públicas” (Pappi; Knoke, 1991) ou “estruturas de implementação" (Hjern; Porter, 1981), originários das abordagens de políticas públicas, não seriam mais apropriados para este estudo? Haja vista a escassez de protestos, a atuação nas instituições políticas dos atores do movimento e o fato de que entre os seus atores estão profissionais da área de saúde, servidores públicos, militantes partidários, acadêmicos, institutos de pesquisa, associações de pesquisa etc. Talvez o recurso às abordagens de políticas públicas pareça mais pertinente, porém isso é apenas aparência. Vejamos o por quê.

\subsection{Categorias de atores nas abordagens de Políticas Públicas}

A afinidade entre o nosso objeto de estudo e as abordagens de Políticas Públicas evidencia-se na medida em que focamos a atuação do movimento social que busca imprimir as mudanças numa política pública por meio das instituições políticas. A afinidade fica mais evidente ainda, porque o movimento social é composto pelos profissionais do setor, pesquisadores e acadêmicos, servidores públicos, ocupantes de cargos públicos e estudantes, que raramente recorreram aos protestos no seu repertório de ação. Os elementos em jogo - processo da política pública, composição do movimento e perfil de ações coletivas -, tendem a sugerir a adoção das principais categorias construídas nas abordagens de políticas públicas. No entanto, como mostraremos a seguir, esses conceitos abarcam apenas os atores considerados relevantes politicamente e focalizam somente aquelas ações com o impacto direto na política pública. Isto é, oferecem uma visão reduzida dos atores participantes, tanto em termos de trajetória, pois a gênese não é seu foco, quanto em termos de formas de atuação, que vêm acopladas aos atores sem problematização.

A contribuição do nosso trabalho visa justamente mostrar como os atores do Movimento Sanitário, ou seja, aqueles que não fazem parte do jogo institucional, tornaram-se politicamente relevantes. Buscamos iluminar, portanto, uma fase 
anterior àquela que está no centro das atenções analíticas das abordagens de políticas públicas, na qual os atores manuseiam o repertório de ação de movimentos sociais, tentando fazer parte do processo decisório. E é nesses processos que se constroem formas de ação legítimas utilizadas pelos participantes visíveis nas abordagens de políticas públicas. Assim, um ator coletivo pode vir a se transformar em um importante player ao constituir um monopólio de representação, institucionalizar o espaço de decisão em que possa desempenhar um dos papeis centrais e reconstruir constantemente os elementos identitários que conectam os seus membros e o legitimam como representante.

Nossa interpretação acerca das diversas abordagens de políticas públicas constrói um argumento no "atacado", isto é, que se refere a todas as abordagens aqui consideradas. Essas pertencem, como mostra Marques ${ }^{16}$ (2006), à geração que contestou a importância do processo da decisão como momento-chave para a explicação das políticas públicas, e trouxe novos aportes teóricos e analíticos para a intepretação das outras etapas de políticas públicas: Kingdon (1995) trabalhou com os processos que influenciam a formação da agenda; o complexo processo da implementação foi objeto da análise de Hjern e Porter, (1981), como também por Hogwood e Gunn (1984) e Lipsky (1980); a análise da formação das ideias e crenças foi desenvolvida por Sabatier e Jenkins-Smith (1993) ${ }^{17}$ e Hall (1993)18; enquanto Laumman e Knoke (1987) ${ }^{19}$ introduziram as redes ao estudo da política, focando as constelações de atores envolvidos com a formulação e a defesa da implementação de alternativas de políticas (Marques, 2006: 18-19). Para demonstrar nosso argumento, optamos por apresentar em detalhes uma delas, talvez a que mais tangencia os processos e os atores que analisamos neste trabalho, a de Kingdon (1995), para, em seguida, trazer de forma menos detalhada as de Sabatier e Weible (2007), a de Pappi

16 As referências citadas por esse autor em sua sistematização da literatura sobre as políticas públicas e que não foram consultadas por nós serão citadas nas notas de roda pé seguintes.

17 SABATIER, Paul; JENKINS-SMITH, Hank. (1993) Policy change and learning: an advocacy coalition approach. Boulder, Westview Press.

18 HALL, Peter. (1993) "Policy paradigms, social leaning and the State: the case of economic policymaking in Britain". In: Comparative Politics, 25 (3).

19 LAUMANN, Edward; KNOKE, David. (1987) The organizational state: social choice in the national policy domains. Madison, University of Wisconsin Press. 
e Knoke (1991) e a de Hjern e Porter (1981), sublinhando as linhas gerais das proposições e ressaltando os limites para as questões de que tratamos aqui.

Kingdon (1995), como os demais autores aqui contemplados, busca entender a política pública, suas permanências e mudanças, e analisa aquelas ações dos atores que influenciam a formulação da agenda e a especificação das alternativas. Como ele próprio sustenta, parte-se da identificação dos atores na formulação produzida pelos campos disciplinares especializados e não se ocupa da trajetória da constituição do ator como objeto de sua análise. Se há uma perda em termos da particularidade dos participantes, esse tipo de análise é compensada, afirma Kingdon, pela visão do conjunto de atores e sua influência em duas das etapas analíticas da política pública considerada. Ao adotar analiticamente os atores sociais e estatais, tais como eles são construídos em outros campos disciplinares, acaba aceitando sem problematização as distinções no que se refere ao tipo de ação de cada categoria de atores. Assim, grupos de interesses fazem lobby, comunidades de especialistas constroem e divulgam ideias por meio de debates e encontros, assessores influenciam o processo por estarem próximos ao presidente. Com efeito, a análise foca o tipo de ação considerada legítima e própria de cada um dos atores partícipes sem que se questione o próprio processo de sua constituição.

O objetivo de Kingdon (1995) consiste em analisar de que forma, de um amplo universo de problemas e alternativas, se origina uma lista delimitada e restrita à qual as pessoas relevantes de dentro e fora do Estado dispensam uma atenção especial. Em outras palavras, como se formula a agenda de política pública e como é escolhida a alternativa que será objeto de decisão política. Sua proposta engloba dois conjuntos de elementos analíticos: no primeiro, os três processos denominados fluxo de problema, fluxo de solução e fluxo de política; no segundo conjunto, os participantes e atores relevantes num dado setor de política publica (Kingdon, 1995: 15). O cerne do primeiro fluxo, o do problema, consiste em entender como um fenômeno observável empiricamente (uma condição social, por exemplo) é definido como um problema para o qual a ação do governo se mostra importante e necessária. O fluxo de solução se refere aos processos de geração de conhecimento, no debate público e em visões e soluções técnicas pelos especialistas. $\mathrm{O}$ interesse analítico nesse fluxo reside em iluminar de que maneira os processos de produção e de difusão do 
conhecimento afetam a formulação de agenda e a especificação de alternativas. Por fim, o terceiro fluxo, o de política, busca entender como os fatos (as eleições, por exemplo) influenciam e mudam as etapas das políticas públicas em foco. No que se refere aos participantes, Kingdon os divide, numa primeira classificação, entre aqueles "de dentro do governo" e os "de fora", e depois os classifica em três categorias: como visíveis, invisíveis e empreendedores. A influência de cada um varia dependendo da etapa da política e das condições do contexto.

Em termos de explicação, o autor defende que cada um dos fluxos, separadamente, da mesma maneira que cada grupo de participantes ou cada participante, não é capaz de identificar a razão pela qual certos itens vêm a ocupar a agenda de decisão política. A condição necessária e suficiente para tanto passa pela articulação (coupeling) dos três fluxos. A articulação se dá em janelas de oportunidades, que se abrem de tempos em tempos, evidenciando as condições propícias em cada um dos fluxos. Essa identificação é realizada pelos "empreendedores".

Para cada uma das etapas de política pública em foco, Kingdon (1995) oferece uma proposição composta pela combinação dos fluxos e participantes. $O$ autor analisa o mesmo objeto pela perspectiva de cada participante e, justamente nessa descrição, torna-se clara a seleção estratégica de distinções analíticas que, embora parcimoniosa e útil do ponto de vista da abordagem, restringe a compreensão do ator à ação capaz de influenciar a política pública. Vejamos de perto o desdobramento do argumento analítico no caso da etapa de especificação de alternativas na qual o conceito de comunidade de especialistas, que se aproxima dos atores do Movimento Sanitário, aparece como central.

Para entender a etapa de especificação de alternativas, dois conjuntos de fatores explicativos se apresentam. As alternativas são geradas no fluxo de solução, e os participantes invisíveis - como acadêmicos, pesquisadores, consultores, burocratas de carreira, assessores parlamentares e analistas que trabalham para os grupos de interesse, dentre eles, os especialistas no setor - são particularmente importantes. O autor afirma que “[a]lternatives, proposals, and solutions are generated in communities of specialists [...]" (Kingdon, 1995: 200) e especifica as comunidades por meio de três regularidades: i) as fronteiras das comunidades não 
são muito rígidas e no interior delas coexiste um leque amplo e diverso de orientações e interesses; ii) as ideias geradas ganham a luz do dia por meio de eventos públicos, falas e propostas publicadas; e iii) a fragmentação ou não das comunidades influencia a instabilidade ou estabilidade do embate das ideias. Duas instâncias analíticas de comunidades ganham mais atenção do autor e constituem o foco de suas proposições. São elas as "ideias" que fornecem o principal material empírico para as suas investigações, e os "empreendedores". O autor mostra que as ideias se combinam umas com as outras e se recombinam entre si; umas desaparecem, outras sobrevivem e ganham importância ao ponto de serem consideradas mais proeminentes que outras. Entre os critérios para a sobrevivência das soluções estão padrões de viabilidade técnica, congruência com os valores da comunidade e antecipação de constrangimentos futuros tais como orçamento, aceitação pública e receptividade dos políticos. Os "empreendedores", por sua vez, são indivíduos que levam as ideias para fora das comunidades de especialistas. Eles não têm uma origem pré-definida, mas o que os caracteriza é a vontade de investir recursos próprios na obtenção de ganho futuro, processo que exige um tempo relativamente longo (Kingdon, 1995: 122). Desse modo, são esses atores que se tornam politicamente relevantes no embate entre as alternativas. A categoria de comunidade de especialistas, portanto, é relevante na proposição de Kingdon na medida em que é produtora de soluções, mas as dinâmicas que a atravessam e formas de atuação e ação de seus atores são secundárias, ou melhor, tornadas invisíveis no seu argumento com exceção da ação de empreendedores.

$\mathrm{Na}$ especificação dos papéis dos participantes, que ocupam boa parte da abordagem do autor, essa restrição de ação é reposta. Kingdon (1995) mostra que os atores que pertencem à comunidade de especialistas, como os acadêmicos, pesquisadores e consultores, ocupam posição importante, mas a análise da sua atuação é restrita às atividades de consultoria e à circulação nos importantes cargos no governo. Quanto aos grupos de interesse, por sua vez, Kingdon os especifica: grupos de interesse de negócios e indústria; grupos de interesse profissional; grupos de interesse público e lobistas do governo. A partir disso, aponta como a principal atividade desses grupos o bloqueio das mudanças, o que pode ser explicado pela recusa dos grupos em perder suas posições privilegiadas no setor. Nessa ilustração, 
fica claro o viés da seleção de atores relevantes e da seleção estratégica do tipo de ação baseada no impacto na política: ficam no palco da análise aqueles com capacidade de influenciar o processo, excluindo, desse modo, os atores que estão tentando alcançar o acesso ao Estado.

As limitações das categorias e do desenvolvimento teórico no que se refere aos atores, apontadas na abordagem de Kingdon (1995), não constituem insuficiências, e sim escolhas estratégicas e parcimoniosas do pesquisador que se propõe a entender o complexo processo da formulação de políticas públicas. Se na abordagem do autor, os participantes constituem um elemento principal ao lado dos fluxos, para dar conta da sua diversidade - entre aqueles de dentro do governo e os de fora -, o autor recorreu às categorias de atores já consagradas em literaturas especializadas, importando delas tanto as denominações (profissionais, grupos de interesse, sindicatos etc.), quanto as formas de atuação desses mesmos grupos. Se expõe separadamente cada um dos atores, atribui a eles apenas um tipo de atividade ou característica por meio da qual influenciam a formulação da agenda e a especificação de alternativas, tornando a análise ampla se olharmos pela perspectiva da explicação das etapas de política pública em foco, mas rasa se avaliarmos pelo prisma de um ator. A compreensão da formação dos atores não é o objetivo da abordagem, com efeito termina sem informar sobre como o ator se tornou relevante e sua ação, legítima. Nosso estudo, como veremos na parte da reconstrução do objeto, pretende captar esses episódios.

O conceito de "coalizão de defesa" (advocacy coalition) de Sabatier (Sabatier; Weible, 2007) é também vizinho analítico de agrupamentos de ação coletiva como os movimentos sociais. Supera uma dicotomia simples entre Sociedade e Estado, ao agrupar analiticamente os atores que estão envolvidos numa dada política em torno das crenças das quais são portadores e não pelas posições que ocupam no Estado, na sociedade civil organizada ou no mercado. O autor argumenta que agregá-los em coalizões é a melhor forma de lidar com a multiplicidade dos atores presentes numa política setorial. Em síntese, a abordagem de Sabatier, repousa na estrutura de crenças à qual o autor acopla a proposição sobre os desencadeadores de mudanças, tanto nas crenças, quanto nas políticas. Esses podem ser de três tipos: choques externos, internos e negociações, cada qual com a capacidade de conformar a 
estrutura de oportunidades políticas. ${ }^{20}$ As coalizões de defesa, ou seja, os conjuntos de atores organizados por um crença compartilhada, aproveitam essas estruturas para agir.

A parte própria e mais sofisticada da abordagem da coalizão de defesa está na estrutura de três níveis de crenças, que fornece elementos para a construção das coalizões. O primeiro nível é composto pelo "núcleo duro de crenças fundamentais" (deep core belief), que são produtos da socialização na infância como, por exemplo, liberdade e igualdade, direita e esquerda, como escala política. Por serem tão arraigados, diz-se que são: "[V]ery dificult to change" (Sabatier; Weible, 2007: 194). O segundo nível - "crenças ligadas à política setorial" (policy core beliefs) - são aplicações das crenças fundamentais a uma política setorial, organizadas em onze elementos. Desse nível, afirmam os autores: "[A]lso very dificult to change" (Sabatier; Weible, 2007: 194). No interior desse nível são destacadas as "preferências por políticas públicas" (policy core preference) definidas como "[...] normative beliefs that project an image of how the policy subsystem ought to be, provide the vision that guides coalition strategic behavior, and helps unite allies and divide opponents" (Sabatier; Weible, 2007: 195). São essas preferências que constituem o conteúdo que mantém a coalizão unida. A agregação das coalizões é estabelecida a partir da identificação de dois ou três elementos desse segundo nível do sistema de crenças. E o terceiro conjunto são as "crenças secundárias" (secondary beliefs), que se referem a partes menores do sistema de política, tais como: as causas de um problema numa certa localidade ou a aplicação do orçamento num programa específico. Por serem mais restritas em termos de alcance do que as preferências por políticas públicas, seria mais fácil mudá-las.

A existência dos elementos comuns de crenças entre os atores não implica a formação de uma coalizão, porque, para que isso ocorra, é preciso que eles se coordenem, isto é, que trabalhem juntos para atingir objetivos semelhantes (Sabatier; Weible, 2007: 196). Mas é justamente no momento da constituição da coalizão que a abordagem falha, conforme afirma o próprio idealizador da abordagem. O que ela abordagem não oferece são as proposições de como se formam as coalizões, como se 
reproduzem no tempo e como são superados os problemas de ação coletiva (Sabatier; Weible, 2007: 197). Suas análises chegam, no máximo, a demonstrar que os esforços de coordenação da ação coincidem com os grupos organizados pelas crenças. A força da abordagem está na identificação das (possíveis) coalizões.

Se Sabatier organiza os atores por crenças, sem se referir a nenhuma etapa da política pública em especial, Hjern e Porter (1981) propõem a identificação dos atores a partir dos papéis que desempenham na implementação das políticas públicas, etapa que ganhou um estatuto analítico próprio, quando deixou de ser entendida como mera execução de ordens de cima. Para entendê-la, argumentam os autores, é preciso recorrer às "estruturas da implementação" como aquelas compostas por multiplicidade de atores organizacionais, de diversas origens. Já em 1981, os autores defendiam que boa parte serviços de importantes era fornecida por programas multiorganizacionais: "there are interconnected clusters of firms, governments, and associations which come together within the framework of these programmes implementation structures" (Hjern; Porter, 1981: 250), nos quais o analista dever focar os indivíduos empreendedores como aqueles, de fato, responsáveis pelo seu estabelecimento. A abordagem carece, no entanto, como a de Sabatier, de proposições a respeito de como se formam as estruturas de implementação, isto é, como e por que certos atores passam a fazer parte delas. As teorias existentes à época não ofereciam explicações satisfatórias, razão pela qual Hjern e Porter (1981) defendiam que se tratava de uma questão empírica e propunham a abordagem fenomenológica para tratá-la.

Por fim, a quarta forma de identificar os atores no interior de uma política pertence a Knoke (1994), quem foca a etapa da decisão política. Trata-se de uma abordagem que seleciona os eventos relevantes da política setorial e a partir deles identifica os atores participantes, tendo como critério de seleção o mútuo reconhecimento. $\mathrm{O}$ intuito da abordagem consiste em entender como os conflitos societais resultam nas decisões vinculantes, e para desenhar as fronteiras desses conflitos, o autor cunha o conceito de "domínio de política" (policy domain), definindo-o como conjunto de "[...] formal organizations identified 'by specifying a substantively defined criterion of mutual relevance or commom orientation... concerned with formulating, advocating, and selecting courses of action' to solve that 
domain's problems" (Knoke, 1994: 279). Os participantes de um domínio de política não podem ser especificados a priori, argumenta o autor, e precisam ser definidos empiricamente, o que indica, como no caso de coalização de defesa, que a separação entre o Estado e a Sociedade não é uma distinção analítica da abordagem. A identificação se dá a partir de um evento da política para distinguir aqueles que buscam o mesmo resultado, denominados "atores coletivos" (Knoke; Pappi, 1991). Quando colocados na linha de tempo, esses diversos atores coletivos coordenam, cada um por si, as suas "ações" (action set) de modo a influenciar um dado evento. Assim, constitui-se uma arena de lutas em que conjuntos de ação se opõem uns aos outros, formando "redes de oposição" (opposition networks). Mais claramente do que abordado em Kingdon (1995), a ênfase do autor recai sobre os atores relevantes do ponto de vista dos processos da tomada de decisão política, o que os congela nos papéis desempenhados naqueles momentos. A abordagem de Knoke e Pappi (1991) permite construir o quadro bem detalhado das "batalhas" nas políticas públicas, levando em consideração o posicionamento de cada um em relação aos demais atores, suas estratégias de ação e alianças. A construção desses quadros fornece ao analista, após o levantamento empírico, uma visão nítida acerca dos pontos nevrálgicos na trajetória de uma política pública e as decisões decorrentes.

Mais do que nas outras abordagens, os lugares ocupados pelos atores constituem uma das problemáticas centrais. Tais lugares são analisados a partir das relações de poder, definindo-as como aquelas interações potenciais e assimétricas entre os atores sociais que possibilitam o ator exercer um maior controle sobre o comportamento do outro. O poder pode ser exercido, seja pelo sistema de influência, no qual o acesso à informação desempenha o principal papel, seja pela dominação, no sentido de o ator controlar os recursos (dinheiro, terra, trabalho, capital) e, em função disso, controlar também o comportamento do outro, oferecendo ou retendo o acesso a algum beneficio. Não favorece, no entanto, a realização de uma opção teórica que busca entender como os atores se tornaram detentores desses poderes sobre os outros.

O foco das abordagens discutidas na explicação das políticas públicas tornaria a exigência de incorporar a formação dos atores nos seus arcabouços inadequada e redundante, tendo em vista que diversas vertentes, sobretudo sociológicas, já fazem 
esse trabalho. No entanto, é importante assinalar que entre a formação do ator e a sua atuação como ator relevante há uma lacuna que pode jogar uma luz interessante em suas explicações. Trata-se de compreender aqueles episódios por meio dos quais os atores, antes irrelevantes, dispersos e invisíveis, tornam a sua atuação significativa e considerada pelos outros. As abordagens aqui discutidas mostram-se incapazes, na nossa visão, de analisá-los e interpretá-los. Assim, não oferecem categorias para responder uma série de perguntas advindas da nossa instância empírica: como o movimento de saúde surge durante a Constituinte enquanto um ator relevante e consubstanciado na Plenária Nacional de Saúde? Como os atores do movimento influenciam o desenho da implementação de programas de recursos humanos durante o regime militar? Como o presidente do Inamps, reduto do setor privado, toma decisões que favorecem o setor público em detrimento daquele? Como o Conselho Nacional de Secretários Municipais de Saúde assume posição de destaque nas decisões setoriais na década de $1990 ?$

Em suma, as abordagens de políticas públicas que partem dos atores relevantes não nos oferecem problematizações e categorias correspondentes, não podendo, dessa forma, retratar de que maneira os atores dos movimentos sociais tornam-se importantes nos processos de políticas públicas. De que formas de ação se valeram para estarem entre aqueles que influenciam a tomada de decisão ou participam da implementação de um programa? Para captar esses episódios, as abordagens dos movimentos sociais (com certas correções, como mostraremos a seguir), apresentam uma entrada mais adequada, porque permitem captar os atores nos bastidores, para empregar o conceito goffmaniano, antes que apareçam no placo dos conflitos políticos.

\subsection{Construção do objeto de análise}

As abordagens dos movimentos sociais, conforme mostramos, apresentam uma conceituação limitada da institucionalização nos movimentos sociais, restringindo-a a protestos e à estrutura interna das organizações. Mas por que, 
apesar de não oferecer categorias condizentes, ainda assim é vantajoso utilizar essa teoria? Porque, numa perspectiva mais ampla, o conceito de movimentos sociais oferece uma vantagem rara de poder pensar um sistema de ação de médio ou longo prazo que reúne uma diversidades de atores e iniciativas coordenadas com base no objetivo comum e no reconhecimento de um "nós" em contraposição a "outros", vistos como aqueles que ameaçam. De um ponto de vista mais específico, a Teoria dos Movimentos Sociais dispõe também de uma categoria que permite trabalhar com um amplo leque de ações, o "repertório de ação dos movimentos sociais", sem nos limitar ao estudo de uma única ou específica forma de atuação dos atores sociais.

A principal categoria analítica que guia a presente análise é esse conceito de "repertório de ação dos movimentos sociais", em torno do qual gravitam as demais categorias - as quais são secundárias em termos da pesquisa, todavia, indispensáveis para reconstruir o movimento empírico dos cinco períodos selecionados para a análise. Recorreremos à definição do conceito de "movimentos sociais", decantando três dimensões operacionais - diagnóstico e prognóstico compartilhados, eventos e atores - que reconstroem o Movimento Sanitário nas suas permanências e mudanças no arco temporal que vai de 1974 até 2006. A passagem entre o contexto e o movimento social para o seu repertório de ação será operacionalizada pela categoria de estratégia, no sentido de uma direção geral adotada pelo movimento. A seguir, retomaremos os aspectos mais salientes dos conceitos e seus aspectos operacionais que permitem construir o objeto analítico desta pesquisa, introduzindo algumas correções e alterações necessárias.

Existe uma lista relativamente longa das perguntas clássicas que os analistas têm feito aos movimentos sociais e que exigem uma diversidade de instrumentais analíticos, teóricos e metodológicos para serem respondidas: quando e por que surgem? Quem se une aos movimentos? Como são organizados? O que os movimentos fazem? O que pensam e sentem os participantes dos movimentos sociais? Como as instituições influenciam os movimentos? Por que declinam? E que mudança os movimentos trazem? O conceito de repertório de ação dos movimentos sociais (Tilly, 2006) se apresenta como hábil ferramenta analítica que busca responder, aparentemente, as questões relativas ao que os movimentos fazem, mas é também capaz de delinear o que os movimentos vêm a ser. O cerne do conceito 
indica que, apesar de não terem sempre as suas ações circunscritas pelas normas e regulamentos, os atores dos movimentos sociais recorrem às formas de ação já disponíveis na sociedade, podendo adicionar a elas um ingrediente de inovação. $\mathrm{Ou}$ seja, seus atores se apropriam das formas já utilizadas pelos outros, ainda que nesse processo de apropriação haja espaço para as inovações.

Como indicado na primeira parte do texto, os analistas dão preferência ao repertório de ação que gostaríamos de denominar de "fora das instituições" e, no interior desse conjunto, às ações portadoras de elementos de inovação (pela efetividade que a imprevisibilidade garante em termos de resultados) em detrimento do repertório de ação "fora das instituições" rotinizado. As propostas da ampliação do conceito de repertório de ação dos movimentos sociais empreendidas por Goldstone (2003), Guigni e Passy (1998) e Abers, Serafim e Tatagiba (2011) introduzem as ações por nós denominadas de "via instituições", que - seguindo a ressalva feita por Guigni e Passy (1998) - propomos organizar em outras duas subcategorias, a saber, as "convencionais" e "não convencionais", aplicando essa mesma distinção para as ações que chamamos de "fora das instituições".

Entendemos as ações "fora das instituições" como aquelas que são empregadas sem que os atores sigam as regras que operam nas instituições que eles visam atingir. Promover uma ação fora das instituições não significa necessariamente que ela seja contra uma instituição; significa que sua gramática e construção não pertencem ao modo de operação dessa instituição. Aqui podemos citar o lobby, negociações com o poder executivo, protestos etc. As ações “via instituições" são aquelas nas quais os atores do movimento social leem as regras da instituição e operam por meio delas. E aqui os exemplos poderiam ser a ocupação de cargos no Estado ou a participação institucional no Estado dos atores da sociedade civil. Acreditamos que essa distinção de ações contorna o problema que as categorias de "ação institucionalizada" versus "ação não institucionalizada" poderiam acarretar no sentido de justaposição e carga normativa. As ações “fora das instituições” podem ser institucionalizadas como o são os protestos rotinizados cuja organização é prevista por lei, ainda que eles se processem "fora das instituições". Da mesma maneira, agir "via instituição" não é para nós o sinônimo da institucionalização da 
ação nos termos da literatura, que a associa à rotinização e à qual recusa elementos de inovação.

No interior de cada uma dessas duas categorias de ação introduzimos a distinção "convencional" e não "convencional". A denominação "convencional" diz respeito às condutas esperadas, dentro ou fora das instituições, para as quais existem respostas prontas por parte das autoridades. A "não convencional" refere-se àquelas ações que carregam um elemento inovador, seja no emprego da forma propriamente dita, seja no conteúdo da demanda, e para as quais as autoridades precisam ainda conceber uma resposta. Optamos por usar a denominação "não convencional" ao invés de "inovador", porque a literatura dos movimentos sociais confere à inovação um conteúdo exatamente oposto à burocratizado, rotinizado ou institucionalizado, dotando-a de alto valor de imprevisibilidade.

Por um lado, ao introduzir a possibilidade das ações "via instituições" serem não convencionais, defendemos então que elas não precisam ser necessariamente o sinônimo da ação burocrática. Essa distinção no interior das ações "via instituições" nos permite não tomar a dimensão institucional como sinônimo de rotinizado, despolitizado, burocratizado ao qual o termo institucionalização e seus derivados vêm associados na Teoria dos Movimentos Sociais. Por outro, tendemos a concordar com a literatura quando ela nota que, no momento em que o movimento se torna inteiramente coincidente com o funcionamento da burocracia estatal - totalmente convencional - , não vale mais a pena usar a categoria de movimentos sociais. Queremos, no entanto, evitar o outro extremo que está presente na literatura dos movimentos sociais, onde o institucional é tratado de forma deficitária e, ao ser associado à burocratização, compromete aquilo que é valioso nos movimentos sociais: a capacidade de inovação e criação e o questionamento que os atores dos movimentos têm. Com isso, não estabelecemos a priori que o mundo das instituições seria inteiramente burocrático e rotinizado e que não haveria nele espaço de pensar os movimentos sociais como aqueles atores coletivos que inovam.

Desse modo, o seguinte esquema analítico referente ao repertório de ação dos movimento sociais pode ser oferecido: 
Figura 1 - Categorias do conceito ampliado de repertório de ação dos movimentos sociais

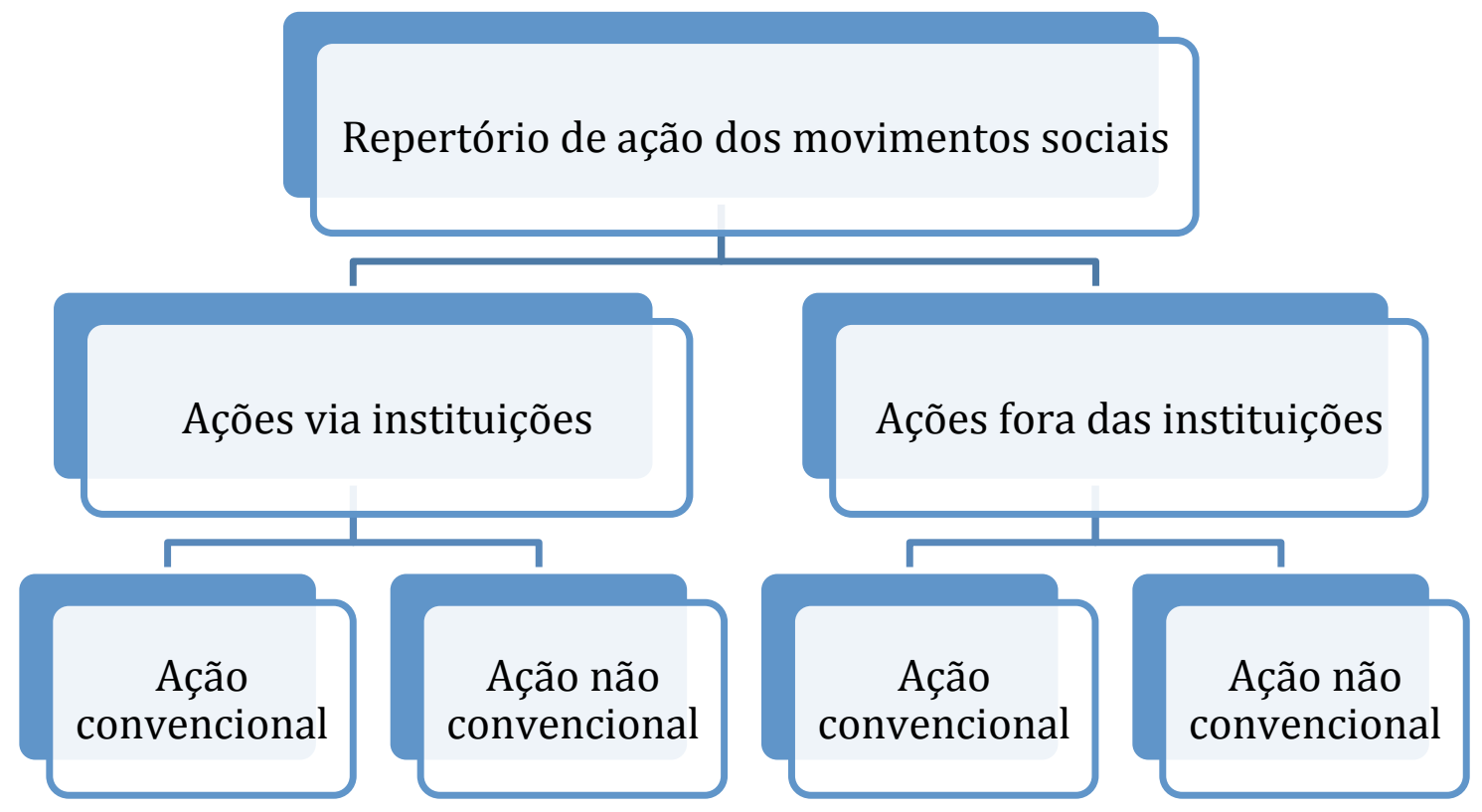

Fonte: Elaboração própria para esta tese

No repertório de ação, incluiremos também a possibilidade analítica do uso das organizações como forma de ação política, tal como sugere Clemens (1993). Os atores fazem escolhas sobre a forma de organização a ser adotada de acordo com a sua leitura do contexto, com base nos recursos que possuem e a partir dos elementos que estão ao seu dispor, isto é, do repertório organizacional. A organização não seria apenas um recurso necessário para a mobilização, tal como está enquadrada na vertente de Mobilização de Recursos. Antes, os atores poderiam usar politicamente a organização ou um conjunto delas.

O uso do repertório de ação fora das instituições oferece ao pesquisador duas vantagens analíticas, que não existem necessariamente para quem foca as ações via instituições. Os protestos constituem a forma de ação dos movimentos contra as autoridades, ao mesmo tempo em que, nos subsequentes ciclos de protesto, as fronteiras do movimento tornam-se visíveis. A visibilidade permite detectar as organizações, os grupos, as redes informais e os indivíduos que se identificam com a 
causa e em função da qual estão mobilizados. Ou seja, os protestos são simultaneamente as formas de ação e os momentos em que o movimento expõe a sua composição. No caso do movimento social que não utiliza o protesto como sua principal forma de ação, a capacidade analítica do repertório de capturar o movimento se enfraquece e coloca o analista diante do desafio de recompor as fronteiras do movimento social de outra maneira. Isto é, o protesto adquire um peso menor, tornando-se de fato apenas uma ação do repertório. Diante disso, o pesquisador encontra-se desprovido da capacidade de identificar os momentos de mobilização nos quais as redes informais de organizações, os grupos e os indivíduos do movimento social e seus enquadramentos se tornam visíveis.

Como os protestos em si não constituem uma forma de ação exclusiva aos movimentos (Meyer; Tarrow, 1998; Tilly, 2006), mas sim sua repetição e recorrência ao longo do tempo, a forma de distinguir um protesto empregado pelo movimento social daquele usado por outro ator social consiste em agrupá-los em ciclos. Nos "ciclos de protestos" (Tarrow, 1998), as entidades dos movimentos realizam constantemente o trabalho de sua organização; os enquadramentos são criados e recriados pelas lideranças; e os participantes mergulham nos momentos coletivos, compartilhando dessas experiências de ação e sentidos comuns. Entretanto, se retirarmos desses ciclos a forma associada, a saber, o protesto, mantendo apenas a reunião das organizações, indivíduos e grupos envolvidos em atividades coletivas relacionadas ao movimento, nos depararemos com sequências de eventos interligados por um sentido comum (Oliver; Myers, 2003: 3).

Com a ressalva relacionada com a categoria de eventos, na reconstrução do Movimento Sanitário, nos pautaremos na definição formulada por Diani, elaborada a partir do esforço de contemplar os elementos comuns a diferentes escolas e tradições de pesquisa em movimentos sociais: "social movements are defined as networks of informal interaction between a plurality of individuals, groups and/or organizations, engaged in political or cultural conflicts, in the basis of shared collective identities" (Diani, 1992: 1). Essa definição ajuda a conectar as partes que pareciam desarticuladas, estabelecendo relações que, antes desse olhar analítico, pareciam inexistentes. Nesses termos, Diani aponta que o conceito desvenda: 
a process whereby several different actors, be they individuals, informal groups and/or organizations, come to elaborate, through either joint action and/or communications, a shared definition of themselves as being part of the same side in a social conflict. By doing so, they provide meaning to otherwise unconnected protest events or symbolic practices, and make explicit the emergence of specific conflicts and issues (see e.g. Melucci, 1989; Eyerman and Jamison, 1990) (Diani, 1992: 2-3).

Apesar da ênfase no conflito, o conceito não se limita às formas de confronto político como cerne da definição, permitindo a inclusão de "eventos" como forma de interação entre os "atores" do movimento e entre eles e seus opositores. Os atores do movimento social, definidos como "plurality of individuals, groups and/or organizations", são conectados pela identidade coletiva, que pode ser capturada pela "definição comum" que os atores tem sobre si próprios como uma coletividade frente a(os) opositor(es) e que compartilham.

Essa definição de Diani (1992), operacionalizada pelas dimensões como eventos, atores e definição comum, nos guiará, portanto, na tarefa de entender as transformações do Movimento Sanitário ao longo do tempo. Obviamente que a reconstrução detalhada do movimento, em semelhança ao trabalho de Escorel (1998), por exemplo, que o faz de forma minuciosa referente ao período de cinco anos, demandaria um esforço para além das possibilidades de uma pesquisa de doutorado. Ainda assim, o levantamento proposto permite tematizar a dinâmica desse ator em cinco momentos diferentes nos quais a pesquisa empírica foi dividida de modo a pensar as questões que esse movimento coloca à literatura e simultaneamente entender como ele funcionou ao longo dos últimos trintas anos.

A "definição comum" será operacionalizada mediante a análise de dois elementos presentes nos textos produzidos pelos movimentos, conforme a abordagem do frame (Bedford; Snow, 2000): diagnóstico e prognóstico, ou seja, a expressão de seu posicionamento político. Tal análise será feita nos documentos difundidos a partir dos "eventos" do movimento e permitirá captar as permanências e as mudanças na visão dos atores ao longo do tempo (1974 a 2006) como também nos informará sobre as organizações, entidades, grupos informais que, num dado período, fazem parte do movimento. O movimento social reconstruído pela análise desses três elementos - diagnóstico e prognóstico, eventos e atores - será inserido na conjuntura de cada período, esboçada por alguns traços políticos mais evidentes. A 
conjuntura não será interpretada pela estrutura de oportunidades políticas (EOP). Embora haja uma pressuposição geral na literatura dos movimentos sociais de que as mudanças na EOP afetam as ações dos movimentos sociais, aqui queremos nos aproximar dela pelo prisma da interpretação e percepção dos atores. Pela leitura do diagnóstico - a avaliação da situação presente e fatores causadores - e do prognóstico - a proposta de ação -, é possível destacar o que os atores consideram como oportunidade ou ameaça. Com base na análise da conjuntura, diagnóstico e prognóstico, eventos e atores, depuraremos quais são as estratégias do movimento entendidas aqui como linhas norteadoras que guiam os atores na seleção das suas táticas. As estratégias constituirão a ponte que nos levará à análise do repertório de ação no qual distinguiremos, conforme mencionado, as ações via instituições a aquelas fora das instituições.

Os atores do movimento recorrem ao repertório de ação do qual escolhem táticas de acordo com a sua interpretação da estrutura de oportunidades políticas e as estratégias que prosseguem. Suas ações poderiam ser avaliadas do ponto de vista de sucesso ou fracasso, de efeitos em relação aos objetivos - embora não seja este o caso nesse trabalho -, ou, em termos mais abrangentes, da capacidade de tornar sua influência mais perene. Aqui considero útil fazer uso de duas categorias que, embora de autores diferentes, guardam entre si uma relação de incremento na influência da ação dos atores no Estado: situações nas quais o movimento ganha "pontos de acesso e influência" (Skocpol, 1995) e quando a influência dos atores se amplia e consolida estabelecendo o “domínio de agência” (Gurza Lavalle; Houtzager; Castello, 2011:10). A introdução dessas duas categorias ao nosso esquema analítico está baseada no pressuposto de que os atores tentam escapar da incerteza e das contingências do processo político, buscando institucionalizar seu acesso e influência no Estado (com o quê se tornam visíveis do ponto de vista das abordagens de políticas públicas).

Os pontos de acesso e influência ao Estado, apresentados por Skocpol (1995), são resultados do encaixe (fit), nos termos da autora, entre os grupos sociais munidos de identidades e capacidades organizacionais e políticas - e as oportunidades que a estrutura das instituições políticas de um Estado oferece a certos atores (e nega a outros). Nessa configuração, as oportunidades são de caráter mais permanente e estrutural do que as oportunidades elencadas no conceito da 
abordagem do Processo Político. A partir disso, por exemplo, a estrutura federativa da tomada de decisão nos Estados Unidos tende a favorecer aqueles grupos que se organizam em todos os níveis federativos e não aqueles concentrados em torno de grandes centros urbanos (Skocpol, 1995: 55). Essas oportunidades são relativas, porque precisam ser percebidas como tais pelos atores, bem como corresponder às suas capacidades organizacionais e políticas, constituindo um encontro, que a autora denomina de encaixe, a partir do qual são produzidos pontos de influência e acesso ao Estado.

O conceito de ponto de acesso e influência carrega necessariamente a ideia de um acesso parcial, que pode, no entanto, se alargar e ampliar de modo a se transformar em domínios de agência. Esses são entendidos como "campos privilegiados de atuação, dotados de barreiras de entrada para novos atores, munidos de procedimentos de admissão e certificação e acesso privilegiado a recursos públicos e privados" (Gurza Lavalle; Houtzager; Castello, 2011: 10). Trata-se daquelas constelações nas quais a influência do ator ganha maior extensão e perenidade. Os domínios de agência são cristalizações institucionais e organizacionais na medida em que significam a continuidade no tempo.

Em síntese, o esquema teórico se apresenta da seguinte forma: uma breve descrição da conjuntura do período/governo em foco constitui o pano de fundo no qual são analisados o diagnóstico da situação que os atores fazem e o prognóstico em termos de plano de ação; a seguir, faz-se o exame dos principais eventos organizados pelo movimento e daqueles identificados com ele e dos seus atores atuantes no período. Esse conjunto de elementos reconstrói o movimento e permite indicar quais são as linhas mestras de ação, isto é, as estratégias do movimento. Com essa indicação se encerra a parte estática da análise, intitulada nos capítulos como “Alteridade em ação". A interpretação dos elementos dessa parte leva à seleção e investigação das ações do repertório, tanto das realizadas "via instituições" quanto das que ocorrem "fora das instituições", de caráter convencional e não convencional. Essa análise está contida na parte dinâmica do estudo, denominada nos capítulos como "Estratégias em prática", e inclui também a análise da construção de pontos de acesso e influência ao Estado ou o estabelecimento de domínios de agência. 


\section{Entre as salas de aula e os gabinetes no Poder Executivo: Movimento Sanitário no governo Geisel (1974-1979)}

\subsection{Conjuntura: governo desenvolvimentista, expansão das políticas sociais e investimento em recursos humanos}

Algumas imagens captam a atuação dos atores do Movimento Sanitário, o qual, na segunda metade dos anos 1970, estava em formação (Escorel, 1998): as salas de aula; a plenária do Congresso Nacional; os eventos acadêmicos e universitários; as mesas de debates; as cartas e os manifestos; as reuniões clandestinas nos saguões dos aeroportos e aquelas que terminavam em debates, noite afora, regadas à chope; os professores que se tornavam secretários municipais de saúde para erguer do início a rede de serviços; os jovens médicos que optavam pela carreira de sanitaristas de modo a trabalhar junto às comunidades pobres; os ativistas que ocupavam os cargos no nível federal do governo; as greves dos médicos residentes...

O período corresponde ao mandato do presidente Geisel (1974-1979), cujo projeto desenvolvimentista de governo incluía a expansão de algumas políticas públicas, entre as quais, as na área da saúde, da ciência e da tecnologia, bem como a preparação de quadros profissionais. Somado a isso, algumas vitórias eleitorais do partido da oposição, tolerado pela ditadura, constituíram um terreno fértil que possibilitou tanto a formação do Movimento Sanitário quanto a prática de algumas das suas táticas.

Em dezembro de 1974, o novo governo militar, sob o comando do presidente Ernest Geisel, anunciava o II Plano Nacional de Desenvolvimento (PND), elaborado por um grupo de técnicos próximos ao Presidente do país, entre os quais, João Paulo dos Reis Velloso, personagem crucial para entender os investimentos em recursos humanos e desenvolvimento tecnológico e científico no país na época (Mantega, 1997: 13). Do ponto de vista econômico, Geisel e sua equipe de economistas apostaram na política desenvolvimentista, voltada para o crescimento do país, apesar do quadro recessivo que havia assolado o panorama mundial com o Choque do Petróleo, em 1973. O II PND propunha políticas que viabilizassem a expansão do 
mercado interno, não mais pela produção de bens de consumo duráveis e não duráveis, mas mediante investimentos em bens de capital. Essa diretriz desenvolvimentista do governo privilegiava um novo conjunto do empresariado brasileiro em detrimento do capital estrangeiro, assim como implicava investimentos nacionais em ciência e tecnologia. Como Mantega afirma:

\begin{abstract}
Contrariando as aparências da primeira hora, Geisel faria um dos governos mais intervencionistas do ciclo militar, respondendo ao cenário recessivo que se formava no horizonte internacional com a manutenção de altas taxas de investimento. Reagiu aos ventos neoliberais, que sopravam com muita força dos países mais avançados em direção ao Continente Latinoamericano, com um programa econômico estritamente desenvolvimentista, que só ampliava a já considerável participação do Estado brasileiro na economia (Mantega, 1997: 5).
\end{abstract}

Para chegar a tais objetivos econômicos, o II PND estabelecia algumas estratégias, entre elas, o desenvolvimento da ciência e tecnologia nacionais e a formação de recursos humanos ocupavam alguns dos lugares centrais.

O II PND anunciava também uma mudança na condução das políticas sociais. Em vez de se apostar no crescimento econômico como mecanismo de melhor distribuição de renda e da melhora das condições de vida da população, o documento estabelecia a necessidade de assumir a interdependência relativa entre as políticas redistributivas e o crescimento econômico, e optar pela realização das primeiras sem esperar os benefícios diretos desse. Tal afirmação contrapunha-se indiretamente ao posicionamento do antecessor de Geisel, cujo ministro da Fazenda pronunciou a famosa frase: "esperar o bolo crescer para, depois, reparti-lo". Assim, para reduzir substancialmente a "pobreza absoluta" e assegurar o aumento substancial da renda real para todas as classes, o plano previa a execução "[...] da politica social articulada, que não constitua simples consequência da política econômica, mas objetivo próprio" (PND II, 1974: 71). As áreas da educação e da saúde, ao lado da infraestrutura de serviços urbanos, tornavam-se prioritárias no campo social (PND II, 1974: 99).

Concretamente, o II PND propunha quatro tipos de ação na estratégia social, dos quais um se referia ao setor da saúde ${ }^{21}$. No Plano estavam previstas tanto a 
ampla formação de profissionais, com o orçamento designado, formulada nos termos do documento como "Política de Valorização de Recursos Humanos, compreendendo, no Orçamento Social, investimentos no valor de Cr\$ 267 bilhões, no período 1975-1979, em Educação, Treinamento Professional, Saúde e Assistência Médica, Saneamento, Nutrição", quanto às reformas institucionais nas agências setoriais de modo a melhorar a sua eficácia. O II PND indicava que "nas áreas de Saúde Pública e Assistência Médica da Previdência, cuidar-se-á da reforma de estruturas para dar capacidade gerencial a esses setores, a exemplo do que já se vem fazendo na Educação, especialmente quanto às Universidades" (PND II, 1974: 73, grifos no original).

Do ponto de vista político, o período estava marcado por avanços e retrocessos, apesar do anúncio do presidente sobre a abertura gradual e segura rumo à democracia. Os resultados das eleições desde 1974 mostraram que o descontentamento estava aumentando: a oposição concentrada no partido tolerado pelos militares, o MDB (Movimento Democrático Brasileiro), foi obtendo sucessivos sucessos no Legislativo federal e em municípios. Uma vez no poder, esses novos políticos progressistas, estivessem no Legislativo ou no Executivo, podiam se tornar aliados do Movimento Sanitário.

\subsection{Alteridade em ação}

Com essa conjuntura como pano de fundo, descreveremos, a seguir, o Movimento Sanitário na sua fase de formação. Começaremos com a definição compartilhada pelos atores do movimento em termos do diagnóstico e prognóstico, na qual ficará claro o projeto político de universalização de acesso à saúde como direito do cidadão e dever do Estado, o qual põe em xeque o modelo vigente caracterizado como excludente e privatizante. A sistematização dos principais

de integração social para a inclusão de novas categorias da população aos benefícios já existentes da política habitacional, da previdência social, dos mecanismos de remuneração indireta como salário desemprego e abono salarial que repõem as perdas inflacionárias (PIS-PASEP) e, por fim, iii) a politica de defesa do consumidor para "garantir preços mais baixos nos produtos de consumo básico, qualidade de medicamentos e segurança nos veículos"(PND II, 1974: 71-73). 
eventos nacionais nos servirá como base para apresentar os grupos e as organizações do movimento, em boa parte ligados a espaços universitários, de formação e de pesquisa e, em menor grau, ao setor público de prestação de serviços de saúde. Por fim, conheceremos os atores do movimento.

\subsubsection{Diagnóstico e prognóstico do Movimento Sanitário: saúde e democracia}

Em novembro de 1976, na capa do primeiro número da revista Saúde em Debate, veículo difusor do Movimento Sanitário, é publicada a charge da principal agência de saúde no país, o Instituto Nacional da Previdência Social (INPS). Principal tanto porque estava a cargo dela a prestação de serviços de saúde à população contribuinte da Previdência como porque concentrava mais de $80 \%$ de todos os recursos setoriais. A charge denuncia o destino perverso da verba que não é convertida em benefícios aos contribuintes: esses aguardam em enormes filas pelo atendimento, enquanto a verba é devorada por uma máquina claramente ávida. A crítica voltada ao INPS sintetiza a posição política dos ativistas do Movimento Sanitário. Os documentos divulgados nos encontros e eventos dessa época, em formato de cartas públicas e manifestos, fornecem os detalhes. Recorremos à voz dos atores para indicar os principais elementos do diagnóstico no qual estava baseada a proposta do movimento para um novo sistema de saúde:

As doenças infecciosas e parasitárias atingem mais da metade da população brasileira, e a estas se somam doenças degenerativas tais como câncer, doenças cardiovasculares e outras que acometem a grande parcela dos brasileiros. A mortalidade infantil vem aumentando progressivamente nos últimos anos, na proporção que vem decrescendo o poder aquisitivo do povo [...] A vida média do brasileiro é ainda muito baixa, já que cerca de $75 \%$ dos trabalhadores recebem menos do que 2 salários-mínimos não podendo assim conseguir alimentos em quantidade e qualidade suficientes para, pelo menos, gerar a energia consumida pelas horas de trabalho e alimentar adequadamente suas famílias. A grande maioria da população vive em condições sub-humanas, habitando moradias sem abastecimento de água e sem redes de esgoto. As favelas, cortiços e alagados se multiplicam assustadoramente nos centros urbanos. [...] Achamos que os fatores acima apontados são os principais responsáveis pela baixa qualidade de vida do povo brasileiro [...] Diante disso, deparamos com a prática de uma Medicina com marcada tendência mercantilista, voltada em grande parte para o lucro e, secundariamente, para a saúde. Tal prática médica passou a existir no 
Brasil, significativamente, a partir da última década. [...] O país vive sob regime de exceção, o povo como principal interessado e verdadeiro financiador do sistema de saúde não pode discutir e colocar livremente as suas reivindicações e muito menos lutar por um sistema de atenção médica voltado para suas reais necessidades (Carta dos Profissionais de Saúde, 1977: $8)$.

Ao associarem as precárias condições de saúde, marcadas pelas epidemias e pelas doenças degenerativas, ao contexto mais amplo no qual se encontrava o país, os atores rompiam com a visão de cunho biológico e elevavam os determinantes políticos, sociais e econômicos à altura da explicação. Não recorriam à história de longo prazo, pois os agentes causadores da precariedade da situação estavam vivos, presentes na arena política e, portanto, eram os alvos diretos das críticas e das reivindicações. O regime autoritário conduziu a política econômica de modo a excluir grande parte da população dos benefícios do crescimento, mantendo-a na miséria. Agravavam a situação a centralização do poder e a consequente exclusão dos atores sociais e políticos dos processos da tomada de decisões que lhes diziam respeito. A configuração do setor de saúde, no qual o macabro INPS da charge desempenhava um papel relevante, era uma decorrência direta do sistema político: excludente, privatizante e "hospitalocêntrico".

A exclusão a qual os atores do movimento se referiam expressava a dualidade do sistema de saúde sob responsabilidade do Estado brasileiro ${ }^{22}$. Havia o subsistema de saúde previdenciário que fornecia os serviços aos contribuintes da Previdência sob o comando do INSP e que, em 1977, abrangia 55 milhões de habitantes do total de 113.208.500 (Possas, 1980: 276). Dispondo de mais de $80 \%$ do total dos recursos setoriais, o caráter privatizante do sistema consistia na contratação de provedores privados para fornecer os serviços de assistência à saúde. Esses eram favorecidos por verbas especiais para a construção dos estabelecimentos hospitalares e pelo Estado que lhes assegurava os contratos: se, em 1960, somente 14,4\% dos leitos pertenciam ao setor lucrativo, em 1975 essa porcentagem já alcançava 54,2\% (Possas, 1980: 309). Todo esse subsistema repousava na assistência médico-hospitalar curativa em detrimento das ações preventivas. O segundo subsistema do qual se incumbia o Estado era voltado àqueles que não contribuíam com a Previdência, ou seja, os que

\footnotetext{
${ }^{22}$ Aqui não nos referimos à prestação privada de serviços de saúde que também existia como opção.
} 
estavam fora do mercado formal de trabalho. Em comparação ao primeiro subsistema, esse era marginal em termos de recursos e estabelecimentos. A população de alta vulnerabilidade do ponto de vista social e econômico podia recorrer apenas a escassos serviços fornecidos pelas Secretarias Estaduais de Saúde visto que os municipais eram praticamente inexistentes (Carvalho, 2011) - e aos estabelecimentos filantrópicos, popularmente chamados "Santas Casas". O Ministério da Saúde (MS) tinha suas ações voltadas principalmente para as campanhas de prevenção. Em resumo, a saúde naquela época no Brasil não era um direito social e sim, por um lado, um benefício prestado mediante a contribuição e, por outro, um serviço praticamente emergencial, rarefeito e apoiado na caridade e filantropia.

A explicação causal identificada no diagnóstico levava ao prognóstico: demandas de democratização, de reformulação do modelo econômico com vistas a melhor distribuição de renda e de melhoria das condições de vida em termos de saneamento básico, habitação, alimentação e educação. Na parte setorial, os atores clamavam pela instalação de um sistema de saúde que integraria, sob comando único, as diversas agências, pelo fortalecimento de serviços públicos nos níveis estadual e municipal e pelo controle do setor exercido pela população e profissionais.

O diagnóstico e o prognóstico apresentados faziam parte de vários documentos que circulavam nos eventos nos quais se encontravam os militantes e os ativistas. Marcaram, por exemplo, a reunião dos ativistas na XXIX Reunião Anual da Sociedade Brasileira para o Progresso da Ciência (SBPC), em 1977, na qual organizaram o simpósio Realidade de Saúde no Brasil e fizeram circular a "Moção contra a privatização" (Moção, 1977: 5). O trecho reproduzido era fragmento da "Carta dos Profissionais de Saúde à População Brasileira" da Associação Nacional dos Médicos Residentes (ANMR), divulgada no Dia Nacional de Saúde e Democracia, organizado na Pontifícia Universidade Católica (PUC-SP). Nessa data, 22 entidades se propuseram a lançar um amplo movimento em prol da saúde pública (Carta dos Profissionais de Saúde, 1977: 8). Em 1979, durante o $1^{\circ}$ Simpósio da Política Nacional de Saúde, realizado no Congresso em Brasília, o texto "A Questão Democrática na Área de Saúde", assinado pela primeira organização do movimento, 
o Centro Brasileiro de Estudos de Saúde (Cebes), refletia a mesma abordagem (Cebes, 1980).

As cartas, os manifestos e os documentos levam-nos aos lugares de sua divulgação e circulação. Trata-se de eventos, em boa parte organizados no meio acadêmico e universitário, nos quais comparecem entidades, grupos e indivíduos do Movimento Sanitário em processo de formação e ainda nas primeiras mobilizações (Escorel, 1998).

\subsubsection{Eventos e atores do Movimento Sanitário}

As cartas e os manifestos apresentados acima coroavam uma série de ocorrências de abrangência nacional na segunda metade da década de 1970. A análise de tais eventos (entre 1974 e 1979) indica sua prevalência na área acadêmica, estudantil ou universitária em relação aos eventos de tipo conjuntural ou aos eventos setoriais, aqueles ligados ao setor público de saúde ou às profissões. A prevalência de eventos com perfil acadêmico não deve causar estranheza. A nova teoria da Medicina Social que embasava o projeto do movimento era produzida nos Departamentos de Medicina Preventiva de algumas universidades desde o início dos anos 1970, entre os quais os mais citados são: o Departamento da Santa Casa de São Paulo, da Universidade de São Paulo (USP), da Escola Paulista de Medicina (EPM), das Faculdades de Medicina de Botucatu, de Ribeirão Preto e da Universidade de Campinas (Unicamp); também são referidos os Departamentos da Universidade Estadual de Londrina (UEL), Universidade de Brasília (UnB), Universidade Federal da Bahia (UFBA), o Instituto de Medicina Social da Universidade do Estado do Rio de Janeiro (UERJ) e a Escola Nacional de Saúde Pública (ENSP) do Rio de Janeiro entre outros (Escorel, 1998; BRASIL/MS/SEGEP, 2006) e, no período em foco, as primeiras turmas dos seus formandos estavam assumindo os postos de trabalho nas universidades, chegando à residência médica, realizando mestrados ou cursos de especialização. Com efeito, não é por acaso que a primeira organização do movimento tenha sido criada, em 1976, na Universidade de São Paulo. 
A ideia da criação do Centro Brasileiro de Estudos de Saúde (Cebes) foi articulada e divulgada por Sérgio Arouca, um dos líderes do movimento e exprofessor do Departamento de Medicina Preventiva da UNICAMP, no anfiteatro da Universidade de Brasília, durante a XXIX Reunião Anual da SBPC, em julho de 1976 (Relatório 2005a: 83). A fundação contou com a participação dos alunos oriundos do Curso de Especialização em Saúde Pública da Faculdade de Saúde Pública da USP, dos diversos Departamentos de Medicina Preventiva, dos servidores da Secretaria Estadual de Saúde de São Paulo e dos integrantes do Programa de Estudos Socioeconômicos em Saúde da Escola Nacional de Saúde Pública no Rio de Janeiro (Escorel, 1998: 75). Em outras palavras, o Cebes foi fundado por aqueles que estavam vinculados aos principais espaços onde se concentravam os núcleos de debates críticos ao sistema de saúde em vigência no país.

A fundação do Cebes propiciou o formato oficial para as reuniões sistemáticas, mas nada formais, dos seus primeiros militantes, que ocorriam no restaurante Degas, no bairro paulistano de Pinheiros, situado bem próximo à Faculdade de Saúde Pública. Quando ocorreu a transferência da sede da fundação para a Escola Nacional da Saúde Pública, no Rio de Janeiro, as reuniões mantiveram o estilo pouco formal. Paralelamente, seus fundadores estavam envolvidos na edição de uma revista, cujo principal propósito era a difusão de ideias inovadoras (Relatório, 2005a: 43). O primeiro número do periódico Saúde em Debate foi lançado em novembro de 1976. O entusiasmo do seu idealizador, David Capistrano Filho, aponta que a ideia da revista estava distante de ser mais um periódico setorial:

\footnotetext{
Numa madrugada muito especial já quase no final de ano [outubro], David não conseguia dormir, não conseguia conter a sua enorme ansiedade. É que logo ali, bem próximo do lugar onde morávamos, estava no prelo o primeiro número da revista Saúde em Debate [...]. Enfrentamos o frio da madrugada e o perigoso deserto das ruas, e assim mesmo fomos a pé até a gráfica, em pleno processo de impressão da revista. Ao ter em suas mãos o primeiro exemplar daquela realização, David, muito emocionado me falou: 'Rosa, você sabe o que isso significa? Você sabe por que eu tinha que vir agora? Esta revista é a nossa primeira vitória! Ela vai provocar grandes transformações (Rosa Barros apud Paula et al. 2009: 152).
}

Um ano depois, a publicação contava com 4 mil assinantes, e o Cebes, com mil sócios e 33 representantes em 16 estados (Paula et al. 2009: 154). Tanto no processo da difusão como na organização dos subsequentes números, os destinos da revista 
sempre dependeram do empenho dos seus criadores que a divulgavam em eventos, viagens e espaços institucionais dos quais faziam parte (Paula et al., 2009: 154; Jouval, entrevista, 2004).

Recém-fundado, o Cebes se fez representar pelos seus integrantes em vários eventos de caráter universitário nos quais era debatido o novo projeto da saúde. Em 1977, ano marcado pela forte mobilização de estudantes universitários do país que ganhavam as ruas em atividades de protesto (Araujo, 2007: 338), o Cebes esteve presente no IX Encontro Científico de Estudantes de Medicina (ECEM) em Florianópolis, no XIX Congresso Brasileiro de Higiene em São Paulo²3, na IV Semana de Estudos sobre Saúde Comunitária (SESAC) em Londrina, no Dia Nacional de Saúde e Democracia na PUC-SP e na Semana de Debate sobre Saúde, no Rio de Janeiro. A participação do Cebes nos três primeiros eventos indica que os militantes aproveitavam os eventos tradicionais da área de saúde para promover encontros de seus membros e divulgar a sua proposta. Os encontros dos militantes em tais eventos, além de resolver de antemão a questão dos recursos e contar com um público cativo, respondiam também às razões de segurança e proteção dos seus participantes contra o aparelho de repressão do regime militar que, apesar de certo clima de distensão, continuava ativo, rastreando e reprimindo as atividades tidas como subversivas.

Um desses eventos de caráter universitário era a Semana de Estudos sobre Saúde Comunitária (SESAC), concebida e organizada inicialmente pelos alunos de medicina de Belo Horizonte e Brasília. O propósito da SESAC, que reunia de 2 a 3 mil estudantes, era debater e compartilhar as experiências em projetos de saúde comunitária, desenvolvidos por algumas universidades e que se diferenciavam dos demais serviços públicos por oferecer cuidados integrais à população em geral, com base na sua participação. Os estudantes convidavam figuras identificadas com uma visão alternativa da saúde e da medicina, como Guilherme Rodrigues da Silva, Cecília Donangelo, Sérgio Arouca, Ana Tambelini e Hésio Cordeiro (Campos, F.,

\footnotetext{
${ }^{23} \mathrm{O}$ Congresso Brasileiro de Higiene, em sua XIX edição, foi realizado por mobilização e imposição dos diversos grupos críticos à organização do setor de saúde, após oito anos de silêncio. Reuniu grupos acadêmicos com militantes nos serviços de saúde, entre eles, os médicos sanitaristas (Nemes Filho, 1992: 42).
} 
entrevista, 2005). Organizados no período da Semana Santa, eram eventos extensos em termos de tempo e dedicação dos militantes, que ficavam ao longo da semana (Escorel, entrevista apud Relatório, 2005b) e envolviam os estudantes na aspiração por transformações, bem como abriam os horizontes de opção profissional para além da prática liberal da profissão, como mostra o depoimento de um sanitarista que era, na época, estudante de medicina:

\begin{abstract}
A gente veio com um ônibus, viemos com um ônibus de Brasília a Campinas, passamos 3 dias aqui [no SESAC de 1975]. Eu assisti uma conferência, creio que me lembro do conteúdo, o título dizia "Saúde e democracia", me parece, e o Sérgio Arouca falou de uma tese que me impressionou muito. Que o Brasil tinha condições técnicas e até recursos financeiros para resolver uma série de problemas de saúde que não resolvia por falta de vontade política e que precisava se construir uma vontade política, de atores e movimentos. Eu como estudante fiquei muito impressionado, [porque] em Brasília a gente tinha uma formação muito cientificista... (Campos, W., entrevista, 2005).
\end{abstract}

Foi na quarta edição do SESAC, em 1977, que os militantes do movimento aproveitaram o espaço do evento para suas reuniões paralelas à programação oficial (Rosas; Campos, 1977)

Entre os eventos conjunturais do período, vale destacar o Encontro por Melhores Condições de Saúde, de 1978, e o 10 Simpósio de Política Nacional de Saúde, de 1979. O Encontro ocorreu nas dependências da Fundação Getúlio Vargas, em São Paulo, sendo a primeira reunião entre os diversos atores em luta pela saúde. Junto com os atores do Movimento Sanitário, como a Associação dos Médicos Sanitaristas de São Paulo (AMSESP), a Associação Nacional dos Médicos Residentes (ANMR), os estudantes de medicina de diversas faculdades e os sindicalistas do Movimento pela Renovação Médica (Doimo; Rodrigues, 2003: 98; Nemes Filho, 1992: 66), encontravam-se também 17 grupos de moradores. O Simpósio, considerado o mais importante encontro pela literatura setorial, foi realizado no Plenário da Câmara dos Deputados. Como o próprio nome indica, não foi um protesto, mas um evento, realizado ao longo de três dias, no qual 800 pessoas debateram a conjuntura e o projeto para as mudanças. Impulsionado pelo núcleo do Cebes de Brasília, que assessorava os parlamentares da oposição nas questões de saúde na Câmara Legislativa (Rodrigues Neto, 2003: 40), o evento foi organizado pela Comissão de Saúde da Câmara e serviu como caixa de ressonância para o projeto do movimento, 
tanto naquele momento como posteriormente, com a divulgação do "A Questão Democrática na Área da Saúde", documento elaborado pelo Cebes e adotado pelo coletivo do Simpósio como a melhor expressão dos debates. Nesse documento estavam expostos com clareza o diagnóstico e prognóstico nos termos apresentados na seção anterior.

Outra organização importante do período em foco foi a Associação Nacional dos Médicos Residentes (ANMR), que dividiu o palco com o Cebes em alguns dos eventos já citados. A ANMR, fundada em 1966, foi uma entidade "tomada" pelos militantes do movimento, que fizeram dela um espaço de formação política dos jovens médicos (no interim que a residência médica constitui entre o término da faculdade e o exercício da atividade profissional) e uma plataforma para a divulgação do projeto do movimento (Gadelha, entrevista, 2005). A Associação Nacional dos Médicos Residentes24, apesar do seu nome, funcionava como agregação das instituições que ofereciam a residência. A partir de 1975, a ANMR iniciou a filiação dos residentes e passou a representá-los, defendendo a regulamentação trabalhista em oposição ao status do residente como estudante de pós-graduação. A inflexão, tanto em termos do perfil dos membros quanto da pauta política, se deu com a volta das, até então pouco ativas, associações estaduais de São Paulo e Rio de Janeiro, que haviam se articulado para promover uma ação comum no $1^{\circ}$ Encontro Rio-São Paulo de Médicos Residentes do início do ano 1975. Amparavam essas associações estaduais os graduados dos Departamentos de Medicina Preventiva de São Paulo e os mestrandos da Medicina Social do IMS do Rio de Janeiro, entre os quais, Paulo Elias, Maria de Fátima Duarte, Antônio Carlos d'Avila, Paulo Gadelha e Marcio Almeida (Gadelha, entrevista apud Relatório, 2005b).

A ANMR recorreu à greve como estratégia de atuação em dois anos, 1978 e 1979, durante a onda de greves que explodiu no país, simbolicamente representadas até hoje pelas greves dos metalúrgicos de São Bernardo do Campo (Kinzo, 1988: 203). Nessas mobilizações, lutava-se pelo reconhecimento do médico residente como trabalhador: em 1978, houve a mobilização bem sucedida em termos da reivindicação "Luta pelo aumento emergencial de cinco salários"; em 1979, a mobilização pela de Paulo Elias de 1987, intitulado "Residência médica no Brasil: institucionalização da ambivalência",. 
"Carteira Assinada", que fracassou em seus objetivos²5. A partir do ano seguinte, as mobilizações cessaram e as associações estaduais de São Paulo e Rio de Janeiro se retiraram do papel de protagonistas que haviam desempenhado no último quinquênio (Elias, 1987: 36-37).

Contudo, como se estivesse substituindo a ANMR, nascia, em setembro de 1979, outra organização do Movimento Sanitário, a Associação Brasileira de PósGraduação em Saúde Coletiva (Abrasco), com o objetivo de "congregar os interesses dos diferentes cursos de pós-graduação naquela área" (Lima; Santana, 2006: 17)). Em uma leitura rápida, poderia deixar de ser notada a nova denominação empregada pelo movimento, qual seja, a de saúde coletiva. Com essa nomenclatura, o grupo de 50 fundadores marcava a diferença em relação aos demais campos de especialização, sejam esses, a saúde preventiva, a saúde comunitária e a saúde pública (Belisário, 2002: 135).

A ideia da constituição da Abrasco havia surgido por iniciativa dos docentes dos cursos de medicina preventiva e dos programas de residência em medicina preventiva das distintas partes do país, que se reuniam, a partir de 1977, em encontros como a $1^{\text {a }}$ Reunião Nacional de Docentes em Medicina Preventiva, em São Paulo; o $1^{\mathrm{o}}$ Encontro Nacional de Pós-graduação em Saúde Coletiva, em Salvador; e o $1^{\mathrm{o}}$ Fórum de Debates sobre a Residência em Medicina Preventiva, também em São Paulo. A Abrasco surgia para politizar a formação de recursos humanos (Fonseca, 2006) e, já em meados dos anos 1980, assumiu a vanguarda política do movimento, fazendo parte das mobilizações e das frentes de pressão nas arenas políticas em que o processo da luta pelo novo sistema de saúde a exigia. Isso significava atuação além do campo acadêmico (Belisário, 2002).

\footnotetext{
${ }^{25}$ A tática de greve foi também utilizada pelo Movimento de Renovação Médica (REME). Embora invisível na nossa sistematização de eventos, o REME também é considerado um ator do Movimento Sanitário (Escorel, 1998; Nemes Filho, 1992), surgido no processo mais geral de renovação do movimento sindical, combatendo as lideranças tradicionais dos médicos por meio de eleições nos sindicatos, liderando campanhas salariais e greves que eclodiram na segunda metade dos anos 1970.
} 


\subsection{Estratégias em prática}

Da descrição realizada acima, fica claro que os atores do Movimento Sanitário não optaram pela estratégia de confronto político para fazer avançar seu projeto de universalização de acesso à saúde como direito do cidadão e dever do Estado. Suas ações, como veremos, passavam por instituições e eram pautadas pelas estratégias do caminho institucional e da formação do campo profissional (Rodrigues Neto, 1997; Escorel, 1998; Paim, 2008). Em relação à primeira, escolhemos os episódios que mostram como os sanitaristas a põem em prática, seja atuando nos programas de expansão de serviços de saúde seja ocupando os cargos nas agências setoriais. A tática associada à segunda estratégia é a da apropriação de espaços e atividades do

Estado para as finalidades do movimento e será apresentada em dois episódios. É importante ressaltar que o texto não seguirá a trajetória histórica da política de saúde. Todavia, os principais eventos, medidas e reformas setoriais fazem parte do relato e constituem o pano de fundo do qual destacaremos a atuação dos atores do Movimento Sanitário.

\subsubsection{Estratégia do caminho institucional}

As mudanças no setor da saúde previstas no II Plano Nacional de Desenvolvimento (PND) do governo Geisel abrangiam reformas de cunho institucional que não alteravam o status quo do sistema em vigência, bem como alguns programas de extensão de serviços. O II PND traduziu-se na instalação, em 1977, do Sistema Nacional de Previdência e Assistência Social (SINPAS), o qual estabelecia que caberia ao novo Ministério da Previdência e Assistência Social (MPAS) uma atuação voltada principalmente para o atendimento médico-assistencial individualizado. Essa atividade foi concentrada, dois anos depois, na agência dedicada à saúde previdenciária, o Instituto Nacional de Assistência Médica da Previdência Social (Inamps). Ao Ministério da Saúde, por sua vez, couberam as ações de saúde pública, entre as quais, a formulação da Política Nacional de Saúde, como também a promoção e a execução de ações preferencialmente voltadas para as 
medidas preventivas e os atendimentos de interesse coletivo (BRASIL. Lei No 6.439, de 1 de setembro de 1977). Essas medidas visavam tornar o sistema mais eficiente, visto que os problemas eram atribuídos a questões gerenciais e administrativas.

Em busca de legitimidade, o governo Geisel apoiou a expansão dos serviços de saúde nas regiões periféricas e pobres do país mediante o Programa de Interiorização de Ações de Saúde e Saneamento (PIASS) (Falleti, 2010). Todavia, a tentativa de fazer dessa uma experiência de alcance nacional, por meio do Programa Nacional de Serviços Básicos de Saúde (Prev-Saúde), mostrou que não se tratava de medidas voltadas para a reorientação radical do setor de saúde e que os representantes do setor privado estavam atentos às ações que podiam prejudicar sua posição (Paim, 2008: 86). O Prev-Saúde, como proposta lançada em 1979, previa estender a cobertura de saúde em termos nacionais e universais, incluindo, no mínimo, 40 milhões de brasileiros (Paim, 1984: 11). Contudo, a proposta não saiu do papel.

Tanto o PIASS, na sua execução, quanto o Prev-Saúde, na sua concepção, contaram com a presença dos sanitaristas. No PIASS, eles ocuparam os cargos de coordenação; no caso do Prev-Saúde, foram seus autores (Santana, entrevista, 2005). Independentemente do resultado, ambos diziam respeito à estratégia de mudança, por caminho institucional, que os ativistas, os militantes e os participantes do movimento buscavam colocar em prática.

O caminho institucional, denominado pelos atores de "ocupação de espaços no Estado", foi formulado como estratégia do movimento em torno de 1978 pelas suas lideranças, entre as quais, Nelson Rodrigues dos Santos, Sérgio Arouca, Eleutério Rodrigues Neto, Guilherme Rodrigues da Silva, Marcio Almeida, Carlyle Guerra de Macedo, que estavam presentes durante as reuniões do grupo denominado "Projeto Andrômeda" (Relatório, 2005b: 277). Tal projeto consistia em encontros fechados e clandestinos - realizados em saguões de aeroportos e hotéis durantes as viagens a trabalho de seus participantes - de um restrito grupo de ativistas, nos quais eram discutidas as estratégias e as táticas que levariam o projeto da democratização da saúde adiante (Relatório, 2005b: 129).

A decisão veio a nomear a atuação desses profissionais naqueles espaços do Estado nos quais era possível colocar em prática a nova visão sobre a saúde. Essas 
experiências tinham em comum a sua localização nos interstícios do sistema em vigência, isto é, foram restritas a programas de abrangência limitada, aos cargos dotados de poder decisório limitado e ao nível municipal que não desempenhava na época um papel de importância na prestação de serviços de saúde. É possível atribuir a estratégia da ocupação de espaços à forma de ação assumida pelo clandestino Partido Comunista Brasileiro (PCB), do qual faziam parte diversos militantes do movimento, ainda que não fosse menor a possibilidade de que outros ativistas, com vínculos associativos distintos, trabalhassem em experiências de expansão de acesso à saúde no Estado. De fato, essa foi uma oportunidade por eles aproveitada, como mostraremos na carreira de sanitarista da Secretaria de Saúde do Estado de São Paulo ou em alguns municípios.

Até o início dos anos 1970, havia uma clara cisão entre as esquerdas brasileiras agrupadas em organizações clandestinas, que optavam pela luta armada como caminho capaz de levar ao socialismo, e o Partido Comunista Brasileiro, que defendia a luta democrática por meio da lei. Depois, em parte devido ao fracasso da luta armada contra o regime militar, houve uma mudança no posicionamento político de parte das esquerdas, que incorporaram a luta democrática em sua atuação, deixando para trás a revolução como horizonte que pautava as ações. Esse deslocamento reafirmou a forma de atuação do $\mathrm{PCB}$, a qual seguia a proposta da união de forças democráticas contra o regime, agindo, no entanto, "dentro da lei”. A opção pela linha reformista diante do regime militar fora feita pelo partido em seu VI Congresso, em 1967, não sem discordâncias e resistências internas daqueles que preferiam a via revolucionária (Silva, 2005: 46). A estratégia do caminho institucional legal visava derrotar o regime por meio de soluções pacificamente negociadas. Os comunistas defendiam a participação em todas as instituições permitidas pelo regime militar, a aliança com todos que se opunham à ditadura em Frentes Democráticas e consideravam possível e desejável reestabelecer a ordem democrática através do caminho eleitoral: "Se no pré-64 'ser comunista' era lutar pelas reformas e ou pela revolução na lei ou na marra, no pós-64 'ser comunista' era lutar pelas reformas e pela revolução apenas na lei" (Pandolfi, 1995: 207).

A opção pela mudança "na lei" significou que o chamado "Partidão" orientasse os seus militantes a se filiarem ao MDB e a ajudarem a "conquistar os 
espaços". Enquanto outras organizações pregavam o voto nulo, o PCB, clandestino desde 1947, aderiu ao MDB e participou das eleições de 1966 (Pandolfi, 1995: 206). As eleições vitoriosas para o partido de oposição de 1974 foram, em parte, a confirmação do sucesso da estratégia dos comunistas de criar uma aliança entre as forças democráticas e de derrotar gradativamente o regime "dentro da lei". De forma clandestina, sem se identificar como tais, em função da constante perseguição de seus quadros pelo aparelho repressivo do regime militar, os comunistas participaram das eleições municipais de 1976, como também das legislativas de 1978, quando cerca de 20 candidatos do partido foram eleitos (Motta, 2007: 298). A forma legalista de atuar também era visível nas universidades, permeadas por várias tendências políticas, das quais a Unidade do PCB se fazia presente em quase todas. Quando, nas assembleias estudantis, se discutia a forma de atuação, os militantes do PCB forçavam a opção pela manifestação “dentro da lei": entre um auditório da associação de jornalistas e as ruas do centro da cidade, optavam pela primeira alternativa (Araujo, 2007: 333).

A linha programática do PCB e as formas de ação decorrentes espelhavam-se na atuação dos atores do Movimento Sanitário, em cujas fileiras encontravam-se ativistas do Partidão ${ }^{26}$ : mobilizações eram organizadas em eventos regulares, pacíficos e sem enfrentamento direto do poder; a atuação "por dentro do Estado", esse sob o controle do regime então contestado, era autorizada como estratégia de derrotá-lo a partir do seu interior e das próprias leis. Com efeito, a estratégia acabou se disseminando e os ativistas, do PCB ou não, buscaram espaços que lhes permitissem atuar de acordo com a perspectiva que tinham da questão da saúde pública. Isso foi possível com a expansão da cobertura de saúde, tanto a promovida pelo governo federal, em busca da legitimidade, quanto por alguns governos estaduais e municipais.

\footnotetext{
${ }^{26}$ Entre as lideranças mais preeminentes do Movimento Sanitário que faziam parte do clandestino PCB estavam David Capistrano Filho, Eleutério Rodrigues Neto, José Temporão, Marcio Almeida, Sérgio Arouca entre outros.
} 


\subsubsection{Tática de atuação em programas e ações com perfil reformista}

Ao longo da segunda metade dos anos 1970, no nível federal e em alguns estados, foram desenvolvidos programas e projetos de expansão de serviços de saúde - sem que se alterassem, todavia, as bases do sistema de saúde como um todo. Esses programas incorporavam em sua coordenação médicos que compartilhavam da nova visão da saúde. Dois exemplos, o de Nelson Rodrigues dos Santos e o de Francisco de Assis Machado, mostram como esses profissionais ocuparam cargos na área de saúde pública. A experiência prévia de ambos os militantes em projetos comunitários e conexões profissionais desempenhou um papel importante nessa inserção.

Nelson Rodrigues dos Santos participou da montagem da primeira faculdade de medicina na Universidade Estadual de Londrina e do Departamento da Saúde Comunitária, dotando-o de um corpo docente multidisciplinar e desenvolvendo, em parceria com o poder municipal, a instalação dos postos de saúde na periferia de Londrina e no norte do Paraná (Santos, 2008/2009: 647). Os serviços eram pautados na atenção integral à comunidade, em vez das tradicionais e limitadas ações preventivas. Não se tratava de uma exceção. Os Departamentos de Medicina Preventiva, do qual se originava o pensamento inovador na saúde, promoviam projetos em regiões ou bairros pobres, chamados na época de "medicina comunitária". Esses projetos serviam tanto de estágios para os alunos como uma forma de experimentação do novo modelo de prestação de serviços. O Projeto Paulínia, por exemplo, foi empreendido pelo Laboratório de Estudos em Medicina Comunitária da UNICAMP, sob a coordenação de Sérgio Arouca e financiado pela Fundação Kellogg. Nesse projeto, os cuidados de saúde prestados pelos profissionais e estudantes de medicina envolviam a participação da comunidade em rodas de discussão sobre a situação sociopolítica no Brasil (Relatório, 2005a: 19).

Por ter sido militante do PCB, e a despeito de ter deixado a atuação no partido em 1964, Nelson Rodrigues dos Santos foi preso em 1973. Quando voltou à Universidade, após um mês no cárcere, o reitor conseguiu impedi-lo de trabalhar, usando para isso medidas administrativas. Condenava, desse modo, o militante ao ostracismo (Santos, 2008/2009). Os relacionamentos de Santos com os dirigentes da 
Organização Pan-Americana de Saúde (OPAS) e do Ministério da Saúde o levaram para Brasília, onde não encontrou dificuldades políticas para trabalhar no Programa de Preparação Estratégica de Pessoal em Saúde (PPREPS). Em seguida, assumiu a coordenação técnica do Programa de Interiorização de Ações de Saúde e Saneamento ${ }^{27}$, programa federal de extensão da cobertura de serviços de saúde que foi implementado no governo Geisel. Voltado para as regiões pobres e municípios de pequeno porte no Nordeste, o PIASS consistiu na construção de minipostos de saúde nos quais o atendimento era fornecido pela mão de obra local capacitada, no PPREPS, para atendimento específico. O programa conseguiu chegar a 700 municipalidades, atendendo $20 \%$ da população do Nordeste. Nas cidades com menos de dois mil habitantes, foram construídos 1250 postos de saúde e, nas de até seis mil, foram instaladas 650 unidades (Falleti, 2010: 51). Após a saída da coordenação em 1978, Santos assumiu um posto de direção na Secretaria Municipal de Saúde na cidade de Campinas, dirigida por outro ativista, Sebastião Moraes.

O segundo coordenador do PIASS que dirigiu especificamente a implementação do programa, entre 1978 a 1979, Francisco de Assis Machado, teve uma trajetória distinta. Não tinha passado pela militância partidária; pertencia à Juventude Universitária Católica (JUC) - um dos ramos da Ação Católica que procurava organizar o movimento estudantil. Assim que se formou, decidiu, com os amigos da JUC, construir uma proposta integrada de serviços de saúde numa pequena cidade de Minas Gerais. Superestimaram suas forças, e Assis se viu, em seguida, trabalhando na Companhia Energética de Minas Gerais (CEMIG), instalado confortavelmente como um clássico profissional liberal de medicina: “Eu estava sendo levado pelos apelos de uma vida pequeno-burguesa com a adesão cada vez maior aos valores do capitalismo: competição, enriquecimento, individualismo, consumismo etc." (Machado, 2010: 57). Entretanto, a reconexão de Machado com o sistema público de saúde deu-se mediante suas relações de amizade. Na Secretaria Estadual de Saúde de Minas Gerais, estavam vários de seus companheiros dos tempos da Juventude Universitária Católica que haviam se transformado em funcionários públicos pelo decreto do então governador Magalhães Pinto, quem

${ }^{27}$ Para conhecer a trajetória detalhada desses projetos, sob o ponto de vista da constituição do Movimento Sanitário, ver Escorel (1998). 
atribuiu esse status a todos os estagiários acadêmicos concursados (Machado, 2010: 13). Um deles indicou Machado para desenvolver o projeto no Vale de Jequitinhonha, um típico programa de saúde pública da época, consistindo na erradicação de doenças transmissíveis. Foi a experiência bem sucedida nesse projeto que destacou o militante para assumir o Projeto Montes Claros, em 1975:

\begin{abstract}
Devo registrar, entretanto, que à época eu não fazia a menor ideia da importância do que iniciávamos naquele Projeto, de um nome tão grande, Sistema Integrado de Prestação de Serviços de Saúde no Norte de Minas Gerais (SISSNM), uma sucessão de experimentos oficiais que, em conjunto, articulariam e constituiriam o grande laboratório do Movimento Pela Reforma Sanitária Brasileira. Para mim, era mais uma oportunidade de criar algumas coisas novas nas relações de trabalho e naquelas que organizavam o funcionamento dos poderes local, estadual e federal, em um setor da administração (Machado, 2010: 109).
\end{abstract}

Desenvolvido pela Secretaria Estadual de Saúde de Minas Gerais nos munícipios pobres do norte do estado, entre 1975 a 1978, o projeto mineiro se tornou um espaço de formação para novos sanitaristas, de encontros entre os ativistas do movimento e um objeto de pesquisa financiado pelo Programa de Estudos Socioeconômicos em Saúde (PESES) da ENSP (Escorel, 1998: 156). Novamente, a capacidade de coordenação e o perfil do Projeto, assentado na provisão integral de saúde, na participação comunitária e no envolvimento dos atores, destacaram Machado, em Brasília, onde foi chamado para a coordenação da segunda fase do PIASS.

A estruturação administrativa do PIASS permitiu a contratação dos coordenadores externos às burocracias envolvidas no programa, possibilitando a entrada dos profissionais que estavam ligados à nova proposta de saúde. A permanência nesses cargos era datada pelo próprio desenho do programa e pelas relações políticas envolvidas. A ocupação dos cargos no Estado, nesse sentido, era temporária, ainda que resultasse no avanço das ações reformistas na ocupação dos espaços: os novos serviços, uma vez instalados, dificilmente seriam desmontados.

Na mesma época de implementação do PIASS, o secretário Walter Leser, na Secretaria Estadual de Saúde de São Paulo, começou a introduzir a reforma administrativa e a ampliação da cobertura de serviços de saúde, conduzidas por um tipo específico de servidor público, o médico sanitarista. Esta carreira foi aproveitada 
por médicos formados oriundos dos Departamentos de Medicina Preventiva e marcados com a nova visão de saúde, os quais ou trabalhariam junto à população ou no desenvolvimento de ações no nível gerencial ${ }^{28}$. A concentração dos jovens reformistas nos cargos de médicos sanitaristas desembocou na reativação de uma associação que se tornou uma organização do Movimento Sanitário (Nemes Filho,1992).

A carreira de médico sanitarista foi instituída em 1969, no quadro de reformas administrativas introduzidas por Walter Leser na Secretaria Estadual de Saúde (Nemes Filho, 1992: 7). Quando Leser reassumiu a Secretaria, em 1975, foi introduzido o plano de extensão e diversificação da assistência médica prestada nos centros de saúde à população excluída do sistema previdenciário, bem como intensificado o processo de contratação dos sanitaristas que, enquanto categoria de servidores públicos, estavam designados para a implementação do plano. Esses servidores eram formados no Curso de Saúde Pública da Faculdade de Saúde Pública. Foi elaborado um curso específico denominado "Curso de Saúde Pública para o Nível Local" que formaria duas turmas por ano, trazendo como consequência - óbvia - o dobro da quantidade de formandos por ano. Entre 1975 e 1979, os cursos qualificaram 396 médicos sanitaristas de carreira, dos quais 315 ingressaram na carreira (Nemes Filho, 1992: 17).

Os ingressantes no curso eram, em sua grande maioria, recém-formados $(74 \%$ tinha entre 25 a 30 anos) dos cursos de residência e pós-graduação dos Departamentos de Medicina Preventiva e pediatria das principais escolas de Medicina do estado de São Paulo (Eduardo, M.B.P.; Abramo, Z. apud Nemes Filho, 1992: 18). Esta procedência atestava o seu contato com propostas críticas à organização do setor de saúde 29 e vários deles se declaravam militantes do projeto da

\footnotetext{
28 A apresentação sobre a atuação dos médicos sanitaristas baseia-se no trabalho de Alexandre Nemes Filho de 1992, intitulado Os médicos sanitaristas e a política de saúde no Estado de São Paulo no período de 1976 a 1988.

${ }^{29}$ Entre as duas primeiras turmas, que foram exclusivamente compostas por egressos desses departamentos, encontrou-se uma parte da turma dos médicos residentes expulsos do Departamento de Medicina Preventiva da Unicamp, dirigido pelo sanitarista Sérgio Arouca. Sua entrada foi possibilitada por indicação do outro sanitarista, Guilherme Rodrigues da Silva, professor na Faculdade de Saúde Pública que tinha contato com Arouca desde o início dos anos 1970.
} 
democratização do país e da reforma da saúdeº (Nemes Filho, 1992: 34). As duas primeiras turmas dos cursos de curta duração, junto com médicos sanitaristas formados nas últimas turmas do curso longo, reativaram a Associação dos Médicos Sanitaristas do Estado de São Paulo (AMSESP), elegendo sua primeira diretoria em 1976 e tornando-a uma organização alinhada com outros atores do Movimento Sanitário em termos do projeto defendido e da estratégia de "atuação por dentro do Estado":

Em função do grau de politização dos Médicos Sanitaristas e das restrições à atividade política impostas pelo regime, a AMSESP representou um 'locus' privilegiado, onde diferentes atores políticos, maciçamente da oposição, representantes de diferentes projetos para a sociedade brasileira, negociavam as propostas específicas para o setor de saúde, definindo as alianças com outros segmentos sociais e os eventos mais importantes onde a categoria deveria atuar (Nemes Filho, 1992: 25).

Os médicos sanitaristas podiam assumir os cargos intermediários na estrutura administrativa da Secretaria (diretoria do Distrito Sanitário, coordenadoria da Saúde da Comunidade, departamentos internos da Secretaria) ou aqueles cargos que os colocavam em contato direto com a população, ou seja, na direção dos Centros de Saúde. A estratégia de caminho institucional, sem ser questionada, desdobrava-se nesse momento em duas táticas concorrentes: "uma orientada para a priorização da intervenção política no aparelho de estado, e a outra priorizando sua ação junto à sociedade civil e em particular ao movimento popular" (Nemes Filho, 1992: 93). Os médicos sanitaristas que optavam pelo trabalho junto às comunidades desempenhavam um duplo papel: trabalhavam em nome da Secretaria e, ao mesmo tempo, fomentavam a organização, participação e reinvindicação da população frente ao poder público nos bairros periféricos da cidade de São Paulo (Nemes Filho, 1992: 22; Martes, 1990: 95). Vários desses sanitaristas faziam da periferia não apenas o seu lugar de trabalho, mas também de moradia, tornando-se parte do nascente

\footnotetext{
${ }^{30} \mathrm{Na}$ formatura da primeira turma, em julho de 1976, o discurso proferido pelos formandos espelhava o conteúdo presente nos documentos das principais mobilizações do movimento, estabelecendo uma ligação clara entre as condições socioeconômicas e as condições de saúde: "Afirmamos que modificações profundas na situação da saúde do nosso povo estão na dependência de alterações significativas no modelo de desenvolvimento econômico e social em vigor, que permitam à maior parte dos brasileiros o acesso aos frutos do crescimento da produção. Tais alterações incluem necessariamente condições favoráveis à ampla participação popular na definição dos rumos do país" (Nemes Filho, 1992: 35).
} 
Movimento Popular de Saúde (MOPS) 31 (Doimo; Rodrigues, 2003). Eduardo Jorge, Carlos Neder e Roberto Gouveia, três médicos sanitaristas, escolheram bairros específicos da zona Leste para atuarem, uma escolha política, no sentido de possibilitar a organização de setores da população na luta contra o regime militar. Eduardo Jorge, por exemplo, foi o diretor do Centro de Saúde de Itaquera entre os anos de 1976-1983.

\title{
2.3.1.2 No coração do sistema (inimigo): tática de ocupação de cargos no nível federal
}

\begin{abstract}
Era uma discussão danada se devíamos ou não trabalhar no Estado que 'era o comitê de negócios de burguesia'. Em plena ditadura militar, ocupar cargos ou funções no governo podia ser considerado até como 'traição. Era uma discussão infindável. Você defendia a importância de entrar nas instituições, de 'abrir espaços' e foi (fomos) muito bombardeado(s) (Arouca in Arouca, 2003: 76).
\end{abstract}

A ocupação de cargos no Inamps, sucessor do "voraz", "corrupto", "privatizante" INPS, retratado na charge da revista Saúde em Debate, descrita no início deste capítulo, era vista como a "entrada no coração do sistema", nas palavras de quem participou dessa forma de ação (Temporão, 2003). O precursor dela, Eleutério Rodrigues Neto, fazia parte dos quadros do PCB e atuou como líder estudantil no curso de medicina da Universidade de Brasília, já marcado pelas ideias inovadoras de Medicina Social (Santana, 2003: 22) e continuou sua formação na pósgraduação na Faculdade de Medicina da Universidade de São Paulo, tornando-se um dos membros do Cebes. Impedido pelo Serviço Nacional de Informação de tomar posse como docente na Faculdade de Saúde Pública, em São Paulo (Jouval, entrevista, 2004), foi acolhido pelo seu professor de graduação, Luis Carlos Lobo, no Nutes-Clates, assumindo a direção, entre os anos de 1977 e 1988, e promovendo encontros entre os integrantes do Movimento Sanitário e cursos voltados para a discussão da saúde no interior do enquadramento do movimento (Pires-Alves, 2011:

${ }^{31}$ O Movimento Popular de Saúde foi bastante estudado e as conexões entre ele e o Movimento Sanitário são relatadas no trabalho de Jacobi (1993) que foca o movimento popular de saúde na Zona Leste de São Paulo na década de 1970, como também na pesquisa de Martes (1990) que estudou as relações entre os governos e o movimento popular de saúde em São Paulo na década de 1980. A trajetória do movimento popular de saúde do Rio de Janeiro foi investigada por Gerschman (2004). 
270). Na época, a militância em prol do Cebes estava intensa. Eleutério buscava novos filiados: daquele época, Jouval recorda Eleutério passando pelos corredores do Nutes-Clates com o carnê de filiação em mãos para angariar novos sócios e arrecadar os recursos para as ações e a manutenção da entidade (Jouval, entrevista, 2004). Toda segunda-feira à noite se encontrava com outros ativistas, nas tradicionais reuniões seguidas de chope no bar Amarelinho - ainda que alguns insistissem, como lembra Arouca, que, por coerência ideológica, devessem frequentar o bar Vermelinho (Arouca, 2003: 75). Eleutério assumiu o primeiro cargo no Estado por indicação de seu outro professor da Universidade de Brasília e membro do Nutes-Clates, Henri Jouval. Tratava-se de um cargo comissionado, penúltimo em termos da importância na hierarquia dos cargos da Direção e Assessoramento Superior (DAS 101.2), cuja nomeação dependia do Ministro, e não do Presidente da República. O responsável pela Secretaria de Serviços Médicos do Ministério da Previdência e Assistência Social (MPAS), Marlow Kwitko, membro fundador da Abrasco, estava procurando alguém para assumir a Coordenação de Planejamento e Estudos da Secretaria, quando lembrou-se de Henri Jouval. Consultado, Jouval recusou, mas indicou Eleutério.

Eleutério desenvolveu durante a sua permanência no cargo, entre 27 de novembro de 1980 a 29 de novembro de 1982, um plano de medidas de perfil reformista que visava racionalizar as ações da agência responsável pela saúde previdenciária, o Inamps, e avançava na integração das ações do MPAS, do Ministério da Saúde e das Secretarias Estaduais de Saúde, ampliando a cobertura dos serviços (Kwitko, 2003: 54). A ideia não era original. Conforme apresentamos, o setor acabara de debater o primeiro Programa Nacional de Extensão Universal de Serviços, o Prev-Saúde, o qual, entretanto, não saiu do papel. O documento elaborado por Eleutério se distinguia desse ao propor uma abordagem menos pretensiosa de medidas e alcançou uma inesperada projeção na crise do sistema que financiava a Previdência Social.

A crise se tornou pública em meados de 1981. Diante de sua gravidade e pouca capacidade de manobra em outras áreas da Previdência, o governo foi levado a convocar um conselho emergencial da saúde previdenciária, o qual foi incumbido de elaborar um plano para sanear a situação. O Conselho Nacional de Administração da Saúde Previdenciária (Conasp) refletia em sua composição a heterogeneidade dos 
atores envolvidos no setor: os representantes do setor privado, os adeptos da prática liberal da profissão, as burocracias setoriais e os reformistas (Rodrigues Neto, 2003: 40; Cordeiro, 1991), mas numa configuração circunstancialmente favorável às mudanças (Santos, entrevista apud Relatório 2005b). Os trabalhos avançavam pouco, conforme mostra o depoimento do chefe de Eleutério, Marlow Kwitko, representante do MPAS no Conasp:

[As] reuniões se sucediam, as manifestações dos conselheiros, representantes das mais diversas procedências eram pontuais, dispersas e tudo indicava que as discussões não trariam elementos para construir um plano. Instigado por Eleutério, reuni-me com o Dr. Aloysio [Salles de Fonseca, presidente do Conasp], manifestando a preocupação com a viabilização do plano e informando que tínhamos um anteprojeto esboçado e ainda não divulgado (Kwitko, 2003: 54).

Aquele anteprojeto era o documento elaborado por Eleutério que, após ter sido apenas levemente modificado pelo Conasp, foi aprovado pelo MPAS, em abril de 1982, tornando-se a política da saúde previdenciária no quadro da crise. O Plano de Reorientação da Assistência à Saúde no Âmbito da Previdência Social, conhecido como o Plano do Conasp, reconhecia as distorções do modelo de organização da área da saúde e previa 17 medidas de caráter racionalizador, todas com o objetivo de controlar a situação mediante redução de custos (Barros; Porto, 2002: 20; Cordeiro, 1991: 31).

O presidente do Inamps, Dr. Aloysio Salles de Fonseca, convidou Marlow Kwitko e Eleutério Rodrigues Neto para assessorarem sua implementação no próprio Inamps e, mais especificamente, na Secretaria de Planejamento, com sede no Rio de Janeiro. Com essa transferência do MPAS para Inamps, Eleutério passou a ser, nas palavras de um ativista do movimento, "nosso agente 'infiltrado' no coração do sistema: na política de assistência médica da Previdência Social" (Temporão, 2003: 56). Esse foi o primeiro cargo considerado estratégico na administração federal, na perspectiva de quem o ocupou, usado para "franqueamento de informações até então monopolizadas pelos estamentos burocráticos conservadores", com vistas ao “próprio avanço do processo de planejamento no interior do Inamps" e para “evolução do processo político representado estrategicamente pelas AIS" (Rodrigues Neto, 2003: 47). Em pouco tempo, porque apenas um ano depois, em maio de 1983, 
Eleutério passou a ocupar, a convite de Jouval, um cargo mais importante, o de diretor no Departamento de Planejamento em Saúde da Direção Geral do Inamps, o que lhe permitia, pela primeira vez, compor a sua própria equipe.

Entre os membros de sua equipe estava José Gomes de Temporão, vice presidente do Cebes da época em que Eleutério era presidente da entidade. Eleutério lhe teria convocado por meio de um telefonema: “Temporão, o Jouval falou com o Aloysio Salles e ele quer conversar com você amanhã". A frase reflete o sistema de nomeação dos cargos comissionados: a composição da equipe estava a cargo do novo diretor do departamento, precisava da anuência do responsável pela secretaria à qual pertencia e era aprovada pelo ocupante do cargo hierárquico mais alto, no caso, o presidente da autarquia. Após essa convocação, Temporão relata que:

[no] dia seguinte, com meu melhor (e único) terno, fui para o gabinete de Eleutério na rua de México, 128, centro do Rio de Janeiro. Enquanto aguardava, fiquei observando a dinâmica daquele espaço... Muitos rostos familiares e um processo de funcionamento não muito diferente dos outros espaços em que compartilhávamos tarefas e projetos. No final da tarde: "Olha, acho que o Aloysio não vai poder te receber, mas ele autorizou tua nomeação" (Temporão, 2003: 57).

Temporão cotejava na época o convite de trabalhar numa secretaria municipal, mas optou pelo Inamps pelo potencial que poderia ter "uma interferência maior no processo global" (Temporão, entrevista, 1987-1988).

Além de Temporão, Eleutério convidou também outra fundadora do Cebes e da Abrasco, Maria de Espírito Santo Tavares Santos (Santinha). Outros membros da equipe haviam passado pelos centros de formação permeados pelas ideias do movimento: Maria de Fátima Siliansky Andreazzi fez o curso de Especialização em Saúde Pública na UERJ, em 1982; Miguel Murat Vasconcelos concluiu o mestrado em Saúde Coletiva, na mesma universidade, em 1981; e Ilara Hämmerli Sozzi de Moraes cursou a Especialização em Saúde Pública pela ENSP, em 1978 (Temporão, 2003).

Todos esses jovens sanitaristas, liderados por Eleutério, estavam no coração do sistema que combatiam. Fruto de uma tática do movimento, sua presença no Inamps não obedeceu apenas à rotina institucional. Eles estavam lá para implementar algumas das medidas do Plano Conasp, que possuía a marca da autoria de Eleutério, e, não por acaso, lhes coube a implementação de um programa de ampliação de 
serviços de saúde. Baseado na ideia dos convênios entre o Inamps e as secretarias estaduais e municipais de saúde, como forma de fortalecer o setor público municipal e expandir os serviços, o Programa de Ações Integradas de Saúde (AIS) era uma das medidas propostas e estava distante de ser, naquele momento, a principal dinâmica da instituição. Todavia, os sanitaristas trabalhavam no sentido de expandi-la, ampliála e torná-la, se possível, a principal dinâmica da instituição (Rodrigues Neto, entrevista, 1987-1988: 10). “Do outro lado do corredor", isto é, na Secretaria de Medicina Social do Inamps, uma equipe colocava em prática o Programa de Racionalização Ambulatorial, que consistia também na extensão da cobertura, mas centrado no setor privado como provedor.

De forma semelhante às divergências sobre a tática de ocupação de cargos no Estado, as AIS foram criticadas pelo Cebes e pela Abrasco, sendo taxadas de "racionalizadoras" e "insuficientes" em relação ao projeto do movimento, tornado público no $1^{\circ}$ Simpósio sobre a Política Nacional de Saúde, em 1979. Os ativistas no Estado não permaneceram como alvos das críticas, alheios ao movimento. Eleutério sugeriu a organização do Seminário de Integração Interinstitucional do Programa AIS. Nesse evento, em fevereiro de 1984:

\begin{abstract}
A FGV [Fundação Getúlio Vargas], a ENSP [Escola Nacional de Saúde Pública], as secretarias e os intelectuais influentes estavam representados para tomar conhecimento da proposta, discuti-la e enriquecê-la com outras visões. Era uma tentativa de ganhar o espaço político, ouvir opiniões divergentes e alimentar o processo do desenvolvimento do projeto (Temporão, 2003: 59).
\end{abstract}

O segundo evento foi promovido pelas próprias organizações do movimento, pelo Cebes e pela Abrasco, em agosto de 1984, com o intuito de avaliar o processo de implementação das AIS nos vários estados brasileiros (Abrasco; Cebes; SESB/PR, 1985: 23). O "Relatório Final da Reunião de Trabalho sobre as Ações Integradas de Saúde", o texto que fechou o evento, concluía que "os avanços significativos [através das AIS] foram conseguidos" e que “[...] o desenvolvimento das AIS nos Estados vem se constituindo em oportunidade sem igual de discussão das questões suscitadas pela integração [das agências responsáveis pela saúde nos três níveis federativos]" e que o coletivo reunido reconhece "o papel extremamente importante que as AIS 
desempenham [como contribuição para a formulação de uma política de saúde democrática]" (Abrasco; Cebes; SESB/PR, 1985: 23 e 24).

$\mathrm{O}$ que os atores do movimento frisavam era um paulatino estabelecimento do domínio de agência alicerçado no seu projeto. As AIS integravam os estados e os municípios como fornecedores de serviços da poderosa agência previdenciária de saúde, restringindo a atuação praticamente exclusiva do fornecedor privado (Rodrigues Neto, entrevista, 1987-1988: 10). Os estados e municípios ganhavam um novo poder de barganha por meio dos convênios e eram incorporados na formulação da política nos níveis nacional, estadual e regional por meio das novas instâncias de planejamento e gestão: a Comissão Interministerial de Planejamento (CIPLAN), as Comissões Interinstitucionais de Saúde (CIS), as Comissões Regionais Interinstitucionais de Saúde (CRIS) e as Comissões Locais e/ou Municipais de Saúde (CLIS ou CIMS). Dessas cinco, as comissões dos níveis regional e municipal ou local contavam com a participação da sociedade civil.

Eleutério foi demitido do cargo comissionado que estava ocupando no Inamps, em setembro de 1984, quando o setor privado conseguiu colocar seu representante na Secretaria do Planejamento e quando saiu da direção Luís Carlos Lobo (Rodrigues Neto, entrevista, 1987-1988: 13). No entanto, em maio do ano seguinte, outro ativista do movimento, Hésio Cordeiro, ocupando a presidência da autarquia, deu continuidade à estratégia das AIS, expandindo-as radicalmente.

2.3.1.4 Ocupar o vazio: tática de ocupação de cargos nas secretarias municipais de saúde

A tática de ocupação de cargos também foi empregada no nível municipal, nas cidades em que os defensores da nova visão do setor de saúde assumiam postos de direção, o que foi viabilizado pela vitória eleitoral do partido de oposição autorizado pelo regime militar, o MDB, em 1976, em algumas cidades de médio porte. Os três secretários identificados com o Movimento Sanitário, os dos municípios de Londrina, Niterói e Campinas (Conasems, 2007), tinham em comum a origem universitária e a 
atuação nos trabalhos em comunidade. Apenas um deles era militante do PCB (Londrina).

Sebastião de Moraes, que assumiu a Secretaria de Saúde em Campinas, não estava ligado à universidade e tampouco a um partido político. Era conhecido pelo trabalho de discussão e debate que fazia junto aos movimentos sociais da Igreja Católica. O convite do vice-prefeito, que conhecia bem a sua atuação, coincidiu com as discussões no grupo de Sebastião acerca da necessidade de institucionalizar o trabalho (Pessoto, entrevista apud Conasems, 2007: 64). Durante a gestão, Sebastião de Moraes, além de levar seu grupo para atuar na Secretaria, adotou as experiências de medicina comunitária desenvolvidas pelos alunos do Departamento de Medicina Preventiva da Unicamp, dentro do Laboratório de Ensino de Medicina Comunitária, coordenado antes por Arouca. A partir de 1977, quando havia apenas quatro unidades de saúde, foram montadas (construídas ou alocadas em casas alugadas), durante os cinco anos seguintes, 36 unidades, que atendiam 20\% da população do município em regiões periféricas (Queiroz; Castro; Viana, 1993: 11)

Em Niterói, por sua vez, o novo prefeito decidiu entregar as áreas sociais de seu governo aos quadros da universidade. Hugo Tomassini, que assumiu a secretaria entre 1977 e 1980, era professor do Departamento de Medicina Preventiva da Faculdade de Ciências da Universidade Federal Fluminense e desenvolvia um trabalho na Vila Ipiranga, região de favelas na cidade, onde a equipe multiprofissional e os alunos faziam atendimento à população. Recorreu às universidades mais próximas (à Universidade Estadual do Rio de Janeiro e à Universidade Federal Fluminense) para compor a equipe na secretaria, tanto no nível central, quanto nos demais níveis técnicos e unidades de serviços (Tomassini, entrevista apud Conasems, 2007: 83). A dupla jornada dos profissionais de saúde na Universidade e na Secretaria de Saúde era facilitada por ambas as instituições na medida em que aquela enxergava nessa combinação uma fonte de recursos para a complementação dos salários dos professores e um laboratório para os estágios dos alunos. Para a secretaria, a contratação dos professores significava acesso à mão de obra com custos mais baixos (Machado, 2010: 86).

Por fim, no caso de Londrina, houve um trabalho direto de dois médicos do Departamento de Saúde Comunitária da Universidade Estadual de Londrina junto 
ao candidato do partido da oposição ao regime militar. Nelson Rodrigues dos Santos e Darli Antônio Soares, do chamado "Grupo Médico", assessoraram o candidato pelo MDB em seu plano de governo (Conasems, 2007: 74) com uma linha programática que focava na instalação de postos de saúde. Vencidas as eleições, o grupo pôde indicar seu candidato para a Secretaria da Saúde, Marcio Almeida, sanitarista, formado nas primeiras turmas do Curso de Especialização em Saúde Pública, militante do PCB e fundador do Cebes. Almeida lembra que o cargo da Secretaria de Saúde foi o último a ser preenchido, porque não havia gente interessada (Conasems, 2008: 75). De forma semelhante a dois outros secretários, a maior parte dos profissionais que compuseram a equipe migrava diretamente da universidade e, mais especificamente, do Departamento de Saúde Comunitária.

A falta de interesse dos políticos e das elites locais pelo setor municipal de saúde refletia o papel secundário, senão irrisório ou inexistente, que o município assumia naquela época na prestação desses serviços. Em 1973, 73,4\% dos municípios não possuíam maternidades, $57 \%$ não tinham hospitais e $90 \%$ não dispunham de prontos-socorros (Carvalho, 2011: 62). Na maior parte dos municípios, sequer havia uma secretaria de saúde propriamente dita, e os poucos serviços eram geridos em outras secretarias ou em espaços que agregavam diversos serviços sociais (Conasems, 2007: 61). Em Londrina, quando Marcio de Almeida assumiu o cargo, a secretaria não dispunha de nenhum médico e nenhum posto de saúde funcionando regularmente:

\footnotetext{
A Secretaria funcionava na época para tomar conta de parques infantis, pois existiam consultórios médicos instalados só em uma das duas creches comunitárias para atender as crianças e o Pronto-Socorro Municipal era conveniado com o Hospital Universitário para o qual a Prefeitura repassava os recursos da saúde (Almeida, entrevista, apud, Conasems, 2007: 75).
}

A Secretaria de Niterói, por sua vez, era conhecida como "secretaria de morte", pois dispunha apenas de um serviço funerário e um posto de saúde, cedido, todavia, à Secretaria Estadual de Saúde em comodato.

Se a ocupação de cargos poderia ser vista apenas como uma oportunidade profissional para aqueles médicos, em 1978 os militantes começaram a organizar uma ação coletiva em torno do setor municipal de saúde, isto é, os eventos anuais intitulados "Encontros do Setor Municipal de Saúde", patrocinados e organizados 
pelos municípios em que os sanitaristas estavam no poder. A ideia de realização de tais eventos municipais teria nascido nas reuniões clandestinas do "Projeto Andrômeda" (Almeida, apud Goulart, 1996). Com base no acerto entre os três secretários, cada um dos municípios abrigariam, sucessivamente, os três primeiros encontros (Goulart, 1996: 38). O primeiro encontro foi realizado em Campinas, em 1978; o segundo, em 1979, em Niterói; e, em 1981, o encontro programado para ser realizado em Londrina foi transferido, porém, para Belo Horizonte, porque o sanitarista havia sido afastado do cargo. Nas palavras de um dos militantes, esses encontros estavam "para além da gestão pública" (Santos, 2008/2009) e sintonizavam com outros eventos organizados pelos atores do movimento: pacíficos, dentro da lei, voltavam-se aparentemente para um público específico. No entanto, também promoviam mobilizações mais amplas, na medida em que envolviam as comunidades atendidas pelos novos serviços municipais, grupos e ativistas de diferentes vertentes do movimento (Carvalho, entrevista, 2012). A Escola Nacional de Saúde Pública, que abrigava vários sanitaristas na época, tornou-se uma das parceiras desses eventos.

Nas eleições seguintes, as de 1982 - portanto, ainda sob o regime militar, mas no quadro do pluripartidarismo introduzido pelos militares com o objetivo de fragmentar a oposição, até então reunida no $\mathrm{MDB}$-, os sanitaristas assumiram cargos em mais algumas cidades como Piracicaba, Bauru e São José dos Campos ${ }^{32}$. Sua atuação na provisão de serviços foi facilitada pelo Programa das Ações Integradas, que repassava os recursos federais aos municípios e estados. Esse programa, como vimos, foi implementado por uma equipe de sanitaristas "infiltrados" no coração do sistema, no Inamps, conduzido pelo sanitarista Eleutério Rodrigues Neto.

\footnotetext{
${ }^{2}$ Em São José dos Campos, a implementação de serviços municipais de saúde por um sanitarista, Gilson Carvalho, havia começado ainda no final dos anos 1970, quando seu prefeito, nomeado pela ditadura, foi afastado. Em 1978, houve uma eleição extemporânea que resultou na vitória de um deputado federal do MDB (Carvalho, entrevista, 2012).
} 


\subsubsection{Estratégia de formação do campo profissional}

Conforme vimos, o II Plano Nacional de Desenvolvimento (PND) do governo Geisel, sob a égide do projeto desenvolvimentista, anunciava o direcionamento de recursos e estabelecia planos específicos para a implementação das diretrizes de fomento à ciência e tecnologia. Ligada diretamente à Presidência da República por meio da Secretaria de Planejamento, criou-se, em 1974, a nova agência de fomento à pesquisa, o CNPq. Decretava-se a execução do II Plano Básico de Desenvolvimento Científico e Tecnológico dotado (como também o era o CNPq) de recursos advindos de três fundos, dois dos quais já estavam em operação: o Fundo Nacional de Desenvolvimento Científico e Tecnológico (FNDCT) e o Fundo de Desenvolvimento Técnico-Científico (Funtec) do Banco Nacional de Desenvolvimento Econômico (BNDE). Por esse Plano Nacional, propunha-se o engajamento das empresas privadas e governamentais no esforço de modernização e inovação tecnológica; estabelecia-se a execução do Plano Nacional de Pós-graduação, além do compromisso com a criação de condições satisfatórias de trabalho dos pesquisadores (com possibilidade de qualificação no exterior); por fim, incentivava-se a "importação dos cérebros" e das tecnologias "de ponta".

A implementação dessas políticas de desenvolvimento da ciência e tecnologia, bem como a formação de recursos humanos na área de saúde, iniciativas que beneficiaram atores do Movimento Sanitário, contaram com uma especial configuração institucional de poder de decisão no governo Geisel (Costa, 1992). Caracterizado pela centralização extrema de poder decisório nas mãos do presidente, o governo funcionava com pequena autonomia dos ministérios que obedeciam as decisões do Conselho de Desenvolvimento Social, incumbido de assessorar o Presidente e coordenar os ministérios desenvolvidos. O primeiro violino nessa orquestra era tocado pelo Ministério do Planejamento, que detinha o poder decisório sobre os destinos do orçamento, condicionados à anuência do presidente (Mantega, 1997: 29). O cargo do ministro de planejamento era ocupado por João Paulo dos Reis Velloso que atuava em parceria com José Pelúcio Ferreira na Financiadora de Estudos e Projetos (Finep), agência que canalizava os recursos para as pesquisas e o desenvolvimento tecnológico. Velloso e Ferreira eram árduos defensores do 
desenvolvimento de ciência, tecnologia e recursos humanos para o país. Uma ilustração da postura e da força política de Velloso era a criação, já em 1964, do Instituto de Planejamento Econômico e Social (IPEA) voltado estritamente para a produção de diagnósticos, pesquisas e programas nas áreas econômica e social. $\mathrm{Na}$ avaliação de seus integrantes, que faziam parte de diversas correntes, o instituto era uma "ilha de liberdade de pensamento" (D'Araujo; Farias; Hippolito, 2004: 108) durante o regime militar, capaz de elaborar ousados diagnósticos e programas para as áreas sociais. Além de proteger o Instituto entre os anos de 1974-1979 (Mantega, 1997), Velloso contribuiu também para a recuperação e desenvolvimento da Fiocruz, indicando uma pessoa de sua confiança e dotando a Fundação de robustos recursos (Relatório, 2005b: 51).

Os investimentos voltados para o desenvolvimento de ciência, tecnologia e recursos humanos, as novas agências estruturadas para viabilizá-los, bem como o apoio dos dirigentes políticos abriram possibilidades para iniciar a estratégia da formação do campo profissional pelos ativistas do movimento. A iniciativa de produzir pesquisas voltadas para as necessidades do sistema público de saúde foi viabilizada pelos recursos da Finep, financiadora de um leque amplo de pesquisas no país. A formação dos sanitaristas sob a nova perspectiva também se baseou na diretriz do II PND, apoiada pela Organização Pan-Americana de Saúde (Nunes, 1998: 63).

\subsubsection{Tática de apropriação de espaços e atividades públicas}

Conta a anedota que o projeto que viabilizou a chegada de mais de trinta pesquisadores e professores escolhidos a dedo por compartilhar de uma visão alternativa de saúde para a Escola Nacional de Saúde Pública (ENSP), entre os quais o grupo do Departamento de Medicina Preventiva expelido da Unicamp, capitaneado por um dos primeiros militantes do movimento Sergio Arouca, foi autorizado pelo Presidente da República na Granja do Torto, ao redor da piscina onde se lia, aos finais de semana, os projetos de certa envergadura a serem financiados pela FINEP e pelo CNPq (Gómez, entrevista, apud Relatório, 2005b). O 
Programa de Estudos Socioeconômicos em Saúde (PESES), que financiou a permanência dos ativistas por alguns anos na ENSP e no interior do qual foram produzidas pesquisas voltadas para os temas ligados à causa da movimento, consistia num simples parágrafo no qual se demandavam seis milhões de cruzeiros que arredondavam para trinta milhões o valor solicitado ao robusto Programa de Estudos Populacionais e Epidemiológicos (PEPPE), que vinha documentado de acordo com as exigências da Finep.

O assentimento do presidente trazia importantes recursos para a Escola Nacional de Saúde Pública (ENSP), sediada na Fundação de Osvaldo Cruz (FioCruz), que havia sido esvaziada em seus quadros na passagem da década de 1970 pelo aparato repressivo do regime militar. Com isso, em 1975, novamente a Fundação era lotada com os profissionais munidos de ideias "subversivas" sobre o sistema de saúde em vigência e as mudanças necessárias.

A entrada desses "subversivos" em uma das instituições públicas de formação e pesquisa precisa ser lida na expansão de investimentos em ciência e tecnologia pelo governo federal. No caso da Fiocruz, a recuperação se iniciou nas gestões de Oswaldo Costa e Ernani Braga na presidência, entre 1973 e 1974, e foi fortalecida com a nomeação de Vinícius da Fonseca, assessor do Ministro do Planejamento, e Reis Velloso, em 1975. Na ENSP, nos "tempos de chumbo", havia ficado um pequeno grupo de pesquisadores, autointitulado "18 de Manguinhos", o que denotava sua predisposição em recuperar a escola. Essa oportunidade surgiu no interior do 2o Plano Básico de Desenvolvimento Científico-Tecnológico (PBDCT) da Finep, de cuja elaboração participou Sergio Góes, diretor da área de saúde da Finep e pesquisador da ENSP. O capítulo de saúde do PBDCT foi escrito por Góes e outro pesquisador da ENSP e, a partir disso, foram criados o PEPPE e o PESES.

Dois outros pesquisadores, Eduardo Costa e Arlindo Fábio Gómez, fizeram contatos a fim de encontrar profissionais para preencher vagas abertas com a chegada dos financiamentos (Gómez apud Relatório, 2005b). Imaginavam uma equipe interdisciplinar, composta por pessoas com a visão da medicina social. Por coincidência, a equipe foi composta pelo grupo liderado por Sérgio Arouca, "banido" 
da UNICAMP33, implicando o emprego de um viés ideológico-político aos projetos. A equipe montada com base nos recursos da Finep produziu, nos anos seguintes, estudos voltados aos temas relacionados à articulação entre ensino, pesquisa e prestação de serviços, entre os quais, o estudo acerca dos departamentos denominado "Investigação Nacional sobre o Ensino da Medicina Preventiva”. Houve também pesquisas sobre o sistema de saúde previdenciário combatido pelos militantes e sobre as formas de repasse dos recursos públicos, munindo os sanitaristas de fortes argumentos pautados em dados e diagnósticos (Sônia Fleury apud Relatório Sérgio Arouca 1976 - 1988, 2005). O PESES apoiou as atividades do Cebes e do Departamento de Medicina Preventiva da Bahia (Nunes, 1998: 76), bem como financiou bolsas de estudos para investigar o projeto Montes Claros do Norte de Minas Gerais, estado onde ocorreu uma importante experiência do modelo de saúde defendido pelo movimento (Escorel, 1998).

A proximidade entre a ENSP e a Finep por meio de pesquisadores que trabalhavam em ambas as instituições deve ter apenas facilitado a circulação da informação sobre as possibilidades de financiamento, mas a resposta positiva da instituição que os financiava, a Financiadora de Estudos e Projetos (Finep), não era uma exceção à regra. A Finep estava alinhada com as ações estratégicas previstas pelo II PND, priorizando investimentos na área de pesquisa e pós-graduação com grandes dotações de recursos.

De uma pequena empresa pública acoplada ao Ministério de Planejamento ${ }^{34}$, criada em 1967, com poucos recursos - seu orçamento, entre 1967 a 1969, não passava de 14 milhões de dólares (Dias, 2002: 20) -, a Finep se tornaria, a partir de 1971, uma agência dotada de sólido fundo reservado para o financiamento de suas ações. A origem desse fundo explica a sua inclinação para o amplo apoio à formação de

\footnotetext{
${ }^{33}$ Há diferentes versões sobre as razões da saída de Arouca e seu grupo da Unicamp, entre as quais são citadas o modo "revolucionário" de conduzir o projeto de medicina comunitária em Paulínia; a tese de Arouca que fazia críticas aguda ao modelo da medicina preventiva em vigor na época, questionando a desigualdade social e clamando pela necessidade da democratização de medicina; a oposição política ao Reitor da época entre outros. O reitor da Universidade solicitou que o grupo de professores e estudantes ligados a Arouca pedisse a demissão (Relatório, 2005a: 19).

${ }^{34}$ A apresentação da Finep se baseia no trabalho de José Luciano de Mattos Dias de 2002, intitulado FINEP: 30 anos de projetos para o Brasil.
} 
recursos humanos, pesquisa fundamental e pós-graduação: os recursos provinham de um fundo do Banco Nacional de Desenvolvimento Econômico (BNDE), denominado Funtec, criado por um grupo de técnicos do Banco, defensores da formação de mão de obra especializada para o país, liderado por José Pelúcio Ferreira. Separado do BNDE por conflitos internos, o fundo foi submetido a uma mudança institucional, sendo deslocado para o Ministério de Planejamento, onde José Pelúcio Ferreira e Reis Velloso haviam assumido cargos de poder decisório. Posteriormente, foi integrado à Finep, recebendo uma injeção adicional de verbas e um novo nome: Fundo Nacional de Desenvolvimento Científico e Tecnológico (FNDCT) . A partir de então, o financiamento para a constituição da infraestrutura de pesquisa no país e de projetos de pré-investimento começaram a funcionar sob o mesmo enquadramento institucional (Dias, 2002: 34).

Em 1973, o I Plano Básico de Desenvolvimento Científico e Tecnológico previa 700 milhões de dólares para as atividades de ciência e tecnologia para o biênio 1973/74, dos quais 25\% foram direcionados ao Programa de Pesquisa Fundamental e Pós-Graduação, sendo a Finep canalizadora desses recursos. Nessa época, sob a direção de José Pelúcio Ferreira, a Finep contava no seu desenho institucional com uma área de elaboração de diagnósticos para orientar seus financiamentos. No seu Centro de Estudos e Pesquisa (CEP), instituído em 1972, foram criados três departamentos especializados: o Departamento de Desenvolvimento Social, o de Políticas Públicas e o de Progresso Técnico e Estrutura Industrial, com aumento considerável de técnicos de nível superior, o que trouxe pesquisadores de centros de pesquisas em regime parcial de trabalho, como foi o caso dos pesquisadores da ENSP. Em 1973, as operações da Finep chegaram ao valor de 320 milhões de dólares, e entre 1973 a 1979, o número de funcionários de nível superior e de apoio passou de 95 a 519 (Dias, 2002: 39).

A Finep assumiu o papel central no financiamento da política tecnológica do governo Geisel, condizente com as diretrizes definidas no II PND. Utilizava com liberdade seus amplos recursos comandados por um grupo de técnicos de alta especialização, liderado por Ferreira. Por sua vez, ele contava com a proteção do ministro do Planejamento, João Paulo dos Reis Velloso, que desempenhava função central na condução dos investimentos governamentais (Dias, 2002: 32), ao mesmo 
tempo em que tinha acesso direto aos núcleos decisórios do poder concentrados, entre outros, no Ministério do Planejamento:

[...] a empresa passou a comandar os programas de desenvolvimento tecnológico da empresa nacional; a gerência de boa parte dos recursos destinados aos programas de energia, planejamento regional, setorial e urbano; e a parte substancial da pesquisa em universidades, incluindo os cursos de pós-graduação (Dias, 2002: 35).

Como exemplos dos diversos programas que receberam os recursos da Finep, ao longo dos anos 1970, podem ser citados: o Instituto de Física da USP (1975), o Instituto de Nutrição (1975), os projetos de pesquisa do Departamento de Economia da PUC-Rio (1971), o Museu Nacional do Rio de Janeiro (sem data, mas antes de 1974) (Dias, 2002: 42).

Quando terminou o financiamento da Finep, conforme constava do convênio, os integrantes dos projetos deveriam ser incorporados pela ENSP, o que aconteceu na maioria dos casos (Relatório, 2005b), tornando a Escola uma das instituições mais fortemente associadas com o Movimento Sanitário (Nunes, 1998: 75).

Em 1979, a $1^{a}$ Reunião sobre Formação e Utilização de Pessoal em Nível Superior na Área de Saúde Pública - evento de título extenso e de estranhamento imediato -, realizada na sede da OPAS, reuniu mais de 50 pessoas entre técnicos, profissionais, alunos e professores, com o intuito de fundar a segunda entidade do Movimento Sanitário, a Abrasco. Associação essa que congregaria "os interesses dos diferentes cursos de pós-graduação naquela área [de Saúde Coletiva]". A fundação da Abrasco expressa a segunda estratégia do Movimento Sanitário, qual seja, a formação do campo profissional, ainda que não se possa reduzir a atuação da entidade a tal estratégia (Belisário, 2002). Os marcos da sua fundação nos oferecem elementos para entender como a estratégia era viabilizada: a presença da organização internacional, a OPAS, os cursos de pós lato sensu e a nova denominação "saúde coletiva".

O II PND, em coerência com a sua tendência geral de qualificação acelerada de recursos humanos, estabelecia uma previsão orçamentária de Cr\$ 267 bilhões (II PND, 1974: 72), diretriz que devia refletir uma especificidade na área de saúde, que fora o acordo assinado pelo Brasil com a OPAS para o Programa Geral de 
Desenvolvimento de Recursos Humanos para a Saúde no Brasil. A valorização da formação dos recursos humanos no setor da saúde numa proposta alicerçada na compreensão social e econômica da medicina constituía uma das principais bandeiras da Opas, desde os anos 1960, tendo em Juan César García seu mentor e fomentador. Foi por iniciativa de García que o Instituto de Medicina Social da UERJ abriu o primeiro curso de Pós-Graduação em Medicina Social e em suas primeiras turmas, entre 1974 e 1975, se formaram vários dos futuros sanitaristas que assumiriam a liderança nas organizações e nas atividades do movimento, entre os quais: Reinaldo Guimarães, Fernando Laender, Hésio Cordeiro, José Noronha, Nina Pereira Nunes, Paulo Buss, Sonia Fleury, José Marcio de Almeida, Roberto Passos Nogueira $^{35}$ (Castro, 2008: 82).

O acordo foi assinado em novembro 1973 e tinha por orientação as recomendações presentes no II Plano Decenal de Saúde para as Américas, de outubro de 1972. No contexto da preparação do II PND, o Ministério da Saúde convocou uma comissão, em junho de 1974, para elaborar, com base no Acordo com a OPAS, a proposta para o plano de qualificação dos recursos humanos em saúde que seria incorporada ao Plano (Castro, 2008: 126). Além dos quadros ministeriais, a comissão incluía os representantes externos ao Ministério, entre os quais, Ernani Braga da Universidade Federal do Rio de Janeiro (que será o primeiro presidente da Abrasco), duas pessoas da ENSP e uma da Fundação Serviço Especial de Saúde Pública (PiresAlves; Paiva, 2006: 40). A comissão aprontou o plano em novembro, um pouco antes da publicação do II PND, e previa ações em três frentes: no planejamento de recursos humanos, na preparação direta de pessoal de saúde e no desenvolvimento de um programa nacional de preparação e distribuição estratégica de pessoal de saúde (Castro, 2008: 127).

O detalhamento dessa terceira frente do Programa Nacional de Preparação e Distribuição Estratégica de Pessoal de Saúde foi desenvolvido ao longo do primeiro semestre de 1975, por Ernani Braga (UFRJ), Carlos Vidal Layseca e José Roberto Ferreira, ambos da OPAS, tornando o Programa seleiro e financiador de uma série de

\footnotetext{
35 Castro, no seu trabalho Protagonismo Silencioso: A presença da OPAS na formação de recursos humanos no Brasil (2008), indica as conexões entre a OPAS e os militantes do Movimento Sanitário, referindo-se a elas em termos de "vasos comunicantes".
} 
atividades ligadas ao movimento. Com forte marca da autoria de Carlos Vidal, o volume de recursos foi considerado muito ousado ou dificilmente aceitável, na opinião dos demais integrantes da equipe (Pires-Alves; Paiva 2006: 40), mas a proposta foi enviada à Brasília e aprovada integralmente. Se era uma surpresa para quem estava dentro do processo, a decisão parecia coerente e condizente com o previsto no documento norteador da política nacional. O Programa de Preparação Estratégica de Pessoal em Saúde (PPREPS), cujo termo de referência foi entregue ao Ministério da Saúde, em junho de 1976, previa a preparação massiva de pessoal de saúde de nível médio, de tipos técnico, auxiliar e elementar, estimando a capacitação de 160 a 180 mil pessoas entre 1976 a 197936 (Pires-Alves; Paiva2006: 43). A Fiocruz, sob a presidência de Vinícius de Fonseca, assessor de Velloso, tornou-se a instituição responsável pela administração de recursos.

Ao longo de sua vigência, entre 1976 e 1979, o PPREPS realizou uma série de "propósitos invisíveis" (Pires-Alves; Paiva, 2006: 64) que diziam respeito ao fortalecimento das iniciativas dos atores do Movimento Sanitário. Um deles foi a própria reunião da fundação da Abrasco; outro, o financiamento da descentralização dos Cursos de Saúde Pública da ENSP para dez estados que formariam centenas de sanitaristas, entre os quais, quadros importantes do movimento e dirigentes dos serviços públicos de saúde. Sob a égide da compreensão de saúde defendida pelo movimento, a formação se dava em aulas ministradas pelos professores dos Departamentos de Medicina Preventiva. O objetivo era:

Preparar mais rapidamente a massa crítica de recursos humanos para o setor de saúde, em quantidade e qualidade, capaz de criar meios de promover mudanças, na medida em que os cursos também se constituíam em importantes mecanismos de desenvolvimento da política de saúde (ABRASCO, 1983: 125).

O currículo do curso, que fazia parte da grade tradicional da Escola, foi reformulado de modo a corresponder aos novos objetivos. A formação era realizada pelos professores dos Departamentos de Medicina Preventiva, nos quais havia se originado a nova visão da saúde (Souza, apud Observatório, 2006: 47). No lugar das antigas metas que ofereciam aos alunos a possibilidade de fazer "estudo sistêmico de

${ }^{36} \mathrm{O}$ PPREPS formou na realidade 38.548 pessoas, das quais, 22,7\% no nível superior (Castro, 2008: 130). 
relações do homens com seu ambiente e proporcionar conhecimento [...] e práticas sobre a dinâmica de trabalho em grupo e trabalho interdisciplinar" (Uchoa; Paim, 1982: 42-47) estavam as propostas de preparação dos quadros para os programas prioritários de saúde pública e expansão da rede permanente de serviços. Almejavase a "preparação de profissionais para a coordenação de unidades de saúde com base no diagnóstico dos problemas de comunidade, a capacitação para promover a participação da comunidade e para administrar, supervisionar e avaliar o funcionamento de unidades locais de saúde" (Uchoa; Paim, 1982: 42-47). A carga do curso foi reduzida de 1480 horas distribuídas em 200 dias para 800 horas concentradas ao longo de 100 dias. E também abria vagas para outras categorias profissionais que não as médicas, com ênfase crescente na formação ideológicopolítica (Labra; Stralen; Scochi, 1988: 93-94).

Dos 13 convênios assinados pela ENSP, entre 1975 e 1979, doze envolviam as secretarias de saúde e um foi firmado com o Ministério da Saúde, por meio dos quais foram capacitados 1643 sanitaristas, em contraposição aos 281 capacitados entre 1969 a 1974 (Uchoa; Paim, 1982: 29). ${ }^{37}$ A grande maioria dos egressos (60\%) se originava das Secretárias Estaduais de Saúde, 6\% do Ministério da Saúde, 4\% das Secretarias Municipais, 5\% do Inamps e 5\% das universidades, ficando apenas 9\% sem vínculo empregatício (Uchoa; Paim, 1982: 35-36). Entre os egressos dos serviços públicos, 72\% desenvolviam atividades no nível central ou regional (Uchoa; Paim, 1982: 36).

Os Cursos de Saúde Pública da ENSP financiados pelo PPREPS podiam ser classificados como atividades de pós-graduação lato sensu, voltados para os profissionais de saúde, independentemente do perfil da graduação. Havia mais cursos desse tipo financiados pelo PPREPS e voltados para o perfil de medicina social. Nessa categoria, poderiam ser incluídos os cursos desenvolvidos no Núcleo de Tecnologia Educacional Para a Saúde e no Centro Latino Americano de Tecnologia Educacional em Saúde (Nutes-Clates), na Universidade Federal do Rio de Janeiro, onde diversos militantes do Movimento Sanitário e figuras internacionais ligadas à saúde pública eram convidados como palestrantes, entre os quais Hésio Cordeiro, Guilherme Rodrigues da Silva, Sérgio Arouca, no primeiro grupo; e Carlos Gentile de

${ }^{37}$ Entre 1975 a 1986, foram realizados 115 cursos e capacitados 3.624 profissionais em Saúde Publica (Labra; Stralen; Scochi, 1988: 50). 
Mello, Juan Carlos Gárcia, Cristina Laurel, no segundo (Jouval, entrevista 2004; PiresAlves, 2011: 247, 258). O PPREPS fomentou também as residências de medicina preventiva $^{38}$ da ENSP cujo currículo era semelhante ao do Curso de Saúde Pública (Santana, 1982: 73), com ênfase na parte prática. De forma semelhante, seus egressos eram absorvidos em boa parte pelos serviços públicos: das 40 vagas em 197939, as residências evoluíram para 130 em 1980 e para 187 em 1981 (Buss, 1982: 65).

Esse conjunto de atividades faziam parte dos "diferentes cursos de pósgraduação" que pautaram a fundação da Abrasco.

\section{Síntese}

Os atores do Movimento Sanitário, em processo de formação no período analisado neste capítulo, lançaram mão de duas estratégias que visavam realizar seu projeto de universalização de acesso à saúde como direito do cidadão e dever do Estado. Na estratégia do caminho institucional, valeram-se da tática de ocupação de cargos no Estado por meio da indicação. Desse modo, ocupavam o setor municipal de saúde onde a oposição ao regime militar ganhava as eleições. Assumiam também cargos em planos, programas e projetos que condiziam com a sua visão de saúde e ofereciam a possibilidade de expandir o acesso à saúde e promover a participação da comunidade. Ao se introduzirem no Estado, esses militantes tentavam imprimir nas atividades em desenvolvimento (ou naqueles projetos que desenvolveriam) princípios condizentes com o projeto de saúde que defendiam: cuidados integrais, participação da comunidade e envolvimento de serviços públicos em detrimento do setor privado. A teia dessas trajetórias individuais se assentava numa outra malha, a de eventos nos quais as estratégias, as táticas e o projeto do movimento eram

\footnotetext{
${ }_{38}$ Dos 296 egressos, em cinco anos (1978 a 1983), 46,6\% vincularam-se às instituições de serviços públicos; destes, $61,3 \%$ aos serviços públicos estaduais e 11,1\% ficaram nas instituições de ensino (Campos; Girardi, 1984: 51).

${ }^{39}$ Desde seu início, em 1962, até 1980, essas residências formaram somente 182 médicos (Santana, 1982: 71).
} 
debatidos coletivamente, elementos que haviam marcado a formação do Movimento Sanitário (Escorel, 1998).

As táticas do repertório de ação correspondiam às oportunidades da época: a expansão das políticas sociais pelos militares (Draibe, 1989) como forma de legitimar o regime, as vitórias eleitorais do partido da oposição em alguns municípios, a crise financeira do sistema da Previdência e o projeto desenvolvimentista que implicou fortes investimentos em ciência, tecnologia e formação de recursos. Esse último aspecto foi aproveitado para colocar em prática a estratégia de formação do campo profissional, mediante produção de pesquisas e adaptação das atividades de formação existentes à visão do movimento, aproveitando-se as linhas de financiamento disponíveis. A fundação da Abrasco, organização que associava projetos, instituições e indivíduos engajados na promoção de ensino e pesquisa voltados para as necessidades dos serviços públicos de saúde e para a universalização do acesso à saúde, constitui ao mesmo tempo a evidência da importância dessa estratégia para o movimento e da necessidade de dar um contorno organizacional e institucional às táticas que eram altamente contingenciais, ou seja, dependentes de recursos com validade marcada e sem garantias de reprodução.

Entre as táticas empregadas, a ocupação de cargos na mais importante instituição setorial resultou, no contexto de uma crise financeira, na implementação das Ações Integradas de Saúde, que podem ser vistas como uma cristalização institucional - um domínio parcial de agência - que abriu espaço para a atuação de certo tipo de ator, até então irrelevante, seja este, o gestor do setor municipal de saúde. As AIS também alargaram oportunidades para novos profissionais de saúde pública, cuja formação começou a ser alvo de ação dos sanitaristas, como apresentamos, a partir da segunda metade dos anos 1970. 


\section{Gabinetes do Poder Executivo, corredores do Legislativo e o Ginásio de Esportes de Brasília: Movimento Sanitário na transição democrática (1984-1989)}

\subsection{Conjuntura: tempos de mudança}

O período de transição democrática é o tempo caracterizado por grande mobilização social (Schmitter, 1992) e no qual a estrutura de oportunidades políticas está especialmente sujeita a mudanças. Os anos focados neste capítulo, de 1984 a 1989, presenciaram a saída não turbulenta dos militares do poder e a eleição, ainda indireta, do primeiro presidente civil da República, em 1985. Nesse ano, o PMDB (Partido do Movimento Democrático Brasileiro), partido de oposição ao regime militar, chegava pela primeira vez ao governo federal. O nível nacional refletiu a tendência já em curso tanto no nível estadual, no qual, com a volta do pluripartidarismo, a oposição elegeu, em 1982, 10 dos 22 governadores, inclusive os de São Paulo, Minas Gerais e Rio de Janeiro (Lamounier, 2005: 174), quanto no municipal onde, no mesmo ano, o PMDB ganhou 34,9\% dos governos (Fleischer, 2002: 94). Com isso, abriam-se potencialmente os canais de acesso a importantes postos na administração pública, o que revigorou a tática de ocupação de cargos do Movimento Sanitário. Em 1987, iniciava os trabalhos a Assembleia Constituinte, que consolidaria institucionalmente a redemocratização. Tratava-se de uma oportunidade rara de reatualizar, modificar e atribuir conteúdos novos a direitos civis, políticos e sociais, que não deixou de ser notada por diversos setores da sociedade civil organizada. O Movimento Sanitário não ficou alheio a esse processo. 


\section{2 Alteridade em ação}

Na conjuntura da transição, notam-se algumas mudanças nos três elementos do movimento social que compõem a descrição do Movimento Sanitário, quais sejam, projeto, eventos e atores. Se os termos do diagnóstico se mantêm praticamente os mesmos do período entre 1974 a 1979, no prognóstico surge o componente da estatização do setor de saúde. Esse novo elemento é decorrente da ampliação do leque de atores que passam a fazer parte do movimento agora denominado Movimento pela Reforma Sanitária, entre os quais estavam vários sindicatos profissionais, movimentos populares, Igreja Católica, movimentos sociais e diversas organizações da sociedade civil. A incorporação ocorreu num momento muito específico, a saber, na 8a Conferência Nacional de Saúde, em 1986, evento tradicional da burocracia setorial. Aberto à ampla participação, a Conferência foi utilizada de forma não convencional pelos sanitaristas, pois mobilizou milhares de representantes das organizações da sociedade civil, os quais acabaram legitimando o projeto do movimento. A $8^{a}$ Conferência sintetiza o perfil que os eventos do Movimento Sanitário adquiriram nesse período: menos restritos ao campo acadêmico e universitário em comparação ao período anterior.

\subsubsection{Diagnóstico e prognóstico do Movimento Sanitário: a controversa tese da estatização}

Os principais termos do diagnóstico apresentados nos documentos do Movimento Sanitário nessa época não se diferenciam daqueles que estavam postos na segunda metade dos anos 1970. Os elementos do prognóstico, como a universalização, a participação da comunidade e a descentralização, também são repostos, com a exceção da (controversa) tese da estatização, antes ausente nas principais publicações do movimento. Ela surge numa mobilização específica, quando o Movimento Sanitário conseguiu ampliar e diversificar o leque de atores adeptos à causa da Reforma Sanitária ${ }^{40}$, isto é, a estatização consta como uma das

40 Paim (2008), militante do Movimento Sanitário e autor da tese sobre o percurso da reforma sanitária como ideia e movimento, indica que o termo foi cunhado e começou a ser utilizado em meados dos 
reivindicações da $8^{a}$ Conferência Nacional de Saúde, na qual a proposta do Movimento Sanitário, endossada pela voz de milhares de participantes dos diversos setores da sociedade civil, ganhou uma legitimidade inédita.

O diagnóstico da época retoma as determinantes socioeconômicas das condições de saúde da população como ponto da partida. A precária saúde dos brasileiros não resulta da qualidade dos serviços de saúde em si; antes, ela é resultante das "[...] condições de alimentação, habitação, educação, renda, meioambiente, trabalho, transporte emprego, lazer, liberdade, acesso e posse da terra e acesso a serviços de saúde" (Relatório da 8a Conferência, 1986: 4). Essas condições são marcadas no Brasil por forte desigualdade social decorrente da atuação do Estado autoritário e das suas prioridades, nas quais a questão social foi tratada como "acessório face à questão econômica" (Cebes, 1985: 8). O sistema de saúde, observam os atores do movimento, faz parte desse quadro, conduzido por instituições centralizadas, fechadas à participação mais ampla, apoiadas no setor privado como prestador de serviços, constituindo, desse modo, um "modelo assistencial excludente, discriminatório, centralizado e corruptor" (Relatório da 8a Conferência, 1986: 6). A falta de integração institucional da saúde preventiva com a curativa, bem como a predominância dos interesses capitalistas na provisão de serviços curativos delegados pelo Estado, argumentava-se, criam desequilíbrios no setor de saúde. No diagnóstico, estava também entrelaçada a avaliação sobre as Ações Integradas de Saúde (AIS), isso é, as ações reformistas em curso promovidas pelos sanitaristas que ocupavam os cargos no governo federal. O Relatório da $8^{\text {a }}$ Conferência pedia a introdução do controle da sociedade nas instâncias de coordenação das AIS, reconhecendo-as como parte da Reforma Sanitária. Todavia, asseverava que tais medidas não deveriam ser utilizadas como "justificativa para protelar a implementação do Sistema Único de Saúde“" (Relatório da $8^{a}$ Conferência, 1986: 17).

Diante desse diagnóstico, a solução passaria, na visão dos atores do Movimento Sanitário, pela constituição de um novo sistema pautado no acesso à saúde como direito do cidadão e dever do Estado. Nesse sistema, como se ressaltava nos textos, a gestão unificada, a participação dos usuários e a descentralização seriam 
princípios elementares e indispensáveis, reproduzindo as ideias já presentes em 1979 e fornecendo mais detalhes acerca da estruturação do novo modelo de saúde. Apenas no que diz respeito ao papel do setor privado, instalou-se a diferença, mas ela não apareceu antes da $8^{\mathrm{a}}$ Conferência. Nos documentos anteriores ao relatório da $8^{\mathrm{a}}$ Conferência dos atores do movimento (Cebes, 1985; Conass, 1985; Carta de Montes Claros, 1985), tornados públicos à época das eleições que elegeriam o primeiro presidente civil, a questão acerca da estatização da saúde não aparece. Pelo contrário: o setor privado de medicina é incluído no novo sistema. O Cebes afirmava, em 1984, que:

\footnotetext{
[f]rente aos avanços das relações capitalistas na produção de serviços de saúde não podemos simplesmente desconsiderar ou ignorar a inciativa privada no setor. Não há condições, quer econômicas, quer políticas, quer técnicas, para no contexto de transição democrática, prescindir-se da iniciativa privada, responsabilizado-a simplesmente pelos problemas de nossa assistência à saúde (Cebes, 1985: 10).
}

O documento final do evento do Movimento Sanitário, o Simpósio sobre a Política Nacional de Saúde, de 1984, colocava o setor privado como "suplementar" aos serviços públicos estatais, frisando que o novo sistema deveria incluir todas as instituições de saúde, públicas e privadas. Intitulado "Proposta Política para um Programa de Saúde", esse documento foi entregue, como expressão do projeto do movimento, ao candidato à Presidência da República pela oposição, Tancredo Neves.

Se nos documentos até a 8a Conferência de 1986 a questão da estatização não aparece, o Movimento Sanitário é identificado como seu defensor pelos seus opositores. “O decisivo agora é cada um de nós se conscientizar de que o momento é de lutar pela própria vida, na última trincheira", alertava o documento direcionado pela Federação Brasileira dos Hospitais (FBH), uma das principais associações do setor privado e lucrativo de saúde, às suas associadas (Carta da Federação Brasileira de Hospitais-FBH, 1984: 41). Os antagonistas da Federação, denominados "grupo estatizante", colocariam sua permanência no mercado em risco pelos elementos contidos justamente no documento do Simpósio, no qual nada constava acerca da estatização. Ameaçavam a posição do setor privado, apontava a $\mathrm{FBH}$, com a criação de um fundo único de recursos de saúde, do qual as secretarias de saúde dos estados seriam gestoras e distribuidoras; com a canalização prioritária dos recursos para as 
ações básicas de saúde; com a transferência do Instituto Nacional de Assistência Médica da Previdência Social (Inamps) ao Ministério da Saúde (MS), na condição de uma agência subordinada e, por fim, com a mudança do estatuto da rede hospitalar privada para concessionária com papel complementar (FBH, 1984: 41). Com esses postulados efetivados, a rede hospitalar privada perderia o acesso privilegiado ao financiamento, concentrado até então numa única agência, o Inamps. $\mathrm{O}$ atendimento de alta complexidade, que concentrava a maior parte dos recursos, teria de disputálos com outros níveis de atendimento, os quais não eram do interesse empresarial à época.

Se, em 1984, o setor privado temia a estatização, essa questão de fato ganhou a luz do dia, isto é, apareceu como tese pública do Movimento Sanitário, apenas em 1986, numa mobilização inédita de amplo conjunto de atores da sociedade civil reunido em defesa da Reforma Sanitária, a $8^{\text {a }}$ Conferência Nacional de Saúde. “A questão que talvez mais tenha mobilizado os participantes e delegados [...]" - lê-se nas primeiras páginas do Relatório da Conferência " [...] foi a natureza do novo Sistema Nacional de Saúde: se estatizado ou não, de forma imediata ou progressiva." (Relatório da 8a Conferência, 1986: 2). Os setores mais à esquerda, representados pelo Partido dos Trabalhadores (PT), Partido Comunista do Brasil (PCdoB) e pela Central Única dos Trabalhadores (CUT), defendiam a estatização imediata, tanto do sistema de saúde, quanto da indústria farmacêutica (Pereira, 1996), enquanto os demais argumentavam a favor do processo progressivo. No fim, o coletivo votou a favor de uma estatização progressiva como meta (Relatório da 8a Conferência, 1986: 12), mas reivindicando a pronta instalação de controle sobre os procedimentos operacionais do setor privado no campo de saúde para coibir os "lucros abusivos" e indicando a possibilidade da "expropriação dos estabelecimentos privados nos casos de inobservância das normas estabelecidas pelo setor público" (Relatório da $8^{\text {a }}$ Conferência, 1986: 12). A tese da estatização imediata da indústria farmacêutica ficou como o vestígio da ala mais radical da Conferência.

\subsubsection{Eventos e atores do Movimento Sanitário}


Os eventos relacionados com o movimento se disseminaram para além das fronteiras universitárias e acadêmicas - diferente do que havia marcado seu perfil no período anterior (1974-1979) -, e adentraram o setor público de saúde. Se, na segunda metade da década de 1970, a grande maioria pertencia ao perfil universitário e acadêmico, a proporção se inverte entre os anos de 1984 a 1989, quando o movimento se mobiliza, se reúne, debate e se posiciona mais frequentemente por meio de eventos setoriais como, por exemplo, as conferências nacionais.

Os eventos organizados pelos atores do movimento - $1^{\circ}$ Congresso Brasileiro de Saúde Coletiva e eventos da Rede IDA (Integração Docente-Assistencial) - situamse no limiar entre o campo acadêmico e universitário e o setorial. Essa localização reflete a busca da integração entre as atividades de formação, pesquisa e os serviços públicos de saúde e traduz a estratégia de formação do campo profissional. A Associação Brasileira de Pós-Graduação em Saúde Coletiva, a Abrasco, havia organizado seu primeiro evento, o Congresso Nacional da Abrasco, em 1983, mas a edição seguinte expandiu as fronteiras em busca do espaço capaz de agregar não apenas os seus filiados, mas todos os atores ligados à proposta de Saúde Coletiva e, consequentemente, do Movimento Sanitário. O evento passou a se chamar Congresso de Saúde Coletiva, popularmente chamado de Abrascão. Nesse evento, reuniam-se os ativistas, os grupos e as entidades do movimento que antes buscavam acolhimento em eventos organizados por terceiros, como as Reuniões da Sociedade Brasileira para o Progresso da Ciência (SBPC) ou as SESAC (Semanas de Estudos sobre Saúde Comunitária), por exemplo. Outra expressão desse limiar são os eventos da Rede IDA, o Encontro Nacional de Coordenadores de Projetos da Rede IDA/Brasil e o Congresso Rede/ IDA/BRASIL, que abrangiam os projetos denominados Integração Docente-Assistencial, nos quais se buscava associar a formação dos profissionais com os serviços prestados à comunidade.

Entre os eventos ocorridos que estão no limiar entre o caráter setorial e conjuntural destaca-se a organização da Conferência Nacional de Saúde que, embora tradicional no setor, foi aproveitada pelos sanitaristas em um momento e de forma estratégicos, de modo a ampliar as fronteiras do movimento e legitimar a sua proposta. Os sanitaristas, ao ocuparem cargos de alto poder decisório, conseguem se apropriar desse evento da burocracia setorial para a mobilização do movimento, 
como também empregam o mesmo formato organizacional para organizar conferências ligadas a outras temáticas, tais como: saúde da mulher, saúde bucal, saúde indígena, saúde do consumidor, saúde do trabalhador e recursos humanos para a saúde. Esse desdobramento inaugura tais conferências sob a égide dos postulados gerais do Movimento Sanitário. Em todas elas, os atores do movimento foram seus coordenadores e o princípio da ampla participação foi acionado, o que ampliou e diversificou o leque de atores vinculados à Reforma Sanitária. Expressando essa fase, a nova denominação começou a circular para circunscrever o ampliado conjunto de atores que aderiam à luta pelo novo sistema de saúde para o Brasil - o Movimento pela Reforma Sanitária.

O evento mais tipicamente setorial, mas organizado desde o princípio (1978) pelos ativistas do movimento, é o Encontro do Setor Municipal de Saúde que, a partir de 1982, começa a ocorrer junto com o Encontro dos Secretários Municipais de Saúde. Os nomes dos eventos são indícios das mudanças no setor municipal de saúde, captadas pelo movimento. A denominação antiga, Encontro do Setor Municipal de Saúde, que ocorreu pela primeira vez em 1978, indicava a inexistência, na maior parte dos municípios, das secretarias de saúde e, consequentemente, dos secretários de saúde. A denominação seguinte, o Encontro dos Secretários Municipais, reflete a paulatina organização dos serviços de saúde que ganha expressão na estrutura administrativa das prefeituras com a instalação de secretarias próprias. Em 1987, o evento é aproveitado pelos sanitaristas que estavam ocupando cargos dirigentes nas secretarias municipais de saúde para legitimar a fundação da organização nacional dos secretários.

Entre os eventos conjunturais do movimento e promovidos pelos deputados aliados do Congresso, os Simpósios sobre a Política Nacional de Saúde ocorrem em momentos políticos nevrálgicos, figurando como caixa de ressonância e legitimação dos seus projetos e reivindicações. O V Simpósio, em 1984, como já discutido, entregou o documento com a proposta para o setor de saúde ao candidato a cargo da Presidência da República da oposição (Comissão de Saúde, 1984: 33-34). O Simpósio seguinte foi organizado, em 1989, com o objetivo de pressionar o Executivo para encaminhar o projeto da Lei Orgânica de Saúde (LOS), a qual regulamentaria os preceitos da Constituição e pautaria o início da implementação do novo sistema de 
saúde. A aparente falta de eventos em torno da Constituinte pode ser explicada pelo caráter que a mobilização adquiriu naquele tempo, a saber, a Plenária Nacional de Saúde, cuja convocação era realizada de acordo com as necessidades do processo constituinte e, por isso, invisível nos periódicos da imprensa do movimento publicados.

As duas organizações do movimento, o Cebes (Centro Brasileiro de Estudos de Saúde) e a Abrasco, fundadas nos anos 1970, continuaram ativas. A Abrasco, apesar do foco na formação em saúde coletiva, começou a assumir cada vez mais um papel político de "[...] interlocutor junto ao aparelho do Estado, levando as propostas de reformulação do setor, defendidas pelo Movimento Sanitário" (Belisário, 2002: 138). O evento de maior mobilização do movimento, a $8^{\text {a }}$ Conferência, seus desdobramentos e a Constituinte acabaram por agregar um conjunto grande de atores que se unem à causa da reforma sanitária. Eles apareceram concretamente vinculados a uma forma organizacional inovadora, que é a Plenária Nacional de Saúde, constituída em maio de 1987, com o intuito de acompanhar os trabalhos da Constituinte e exercer pressão para que a proposta do movimento fosse aprovada. A Plenária, instalada pela iniciativa do Cebes e da Abrasco, não se constituiu como entidade propriamente dita. Seria mais apropriado designá-la como um fórum de articulação dos atores que estavam no Movimento Sanitário aos quais se agregavam aqueles que não faziam da luta pelo novo sistema de saúde o principal eixo da sua atuação.

As fronteiras do Movimento Sanitário se ampliaram na época e incorporaram cerca de 160 entidades e grupos que participavam das mobilizações promovidas pela Plenária, entre os quais, o Movimento Popular de Saúde (MOPS), os Conselhos de Saúde de vários bairros de São Paulo, as centrais sindicais, as federações, os sindicatos de profissionais de saúde, as associações de trabalhadores de saúde, as entidades científicas e os partidos políticos (Ofício, 1988). A coordenação da Plenária era composta por um conjunto de entidades que possuíam sede em Brasília e, entre elas, encontravam-se as entidades representantes do movimento popular, como a Confederação Nacional das Associações de Moradores (CONAM), o Movimento Popular de Saúde (MPOS); e do movimento sindical, como o Conselho Federal de Medicina, a Federação Nacional dos Médicos, a Associação Brasileira de 
Enfermagem, a Federação Nacional dos Enfermeiros e entidades como o Conselho Nacional de Secretários de Saúde (Conass) (Silva, 2005: 89 apud BRASIL/MS/SEGEP, 2006).

Outra entidade que surgiu nessa época, dando contorno organizacional às atividades do movimento em curso há dez anos, foi o Conselho Nacional de Secretários Municipais de Saúde (Conasems), associação fundada oficialmente em julho de 1987. Liderado pelos sanitaristas, o Conselho associava algumas associações estaduais de secretários existentes na época, tornando-se o representante político dos secretários diante das autoridades federais. O Conasems participará da Plenária e assumirá um papel de destaque nos primeiros anos após a Constituinte, protagonizando a luta contra os vetos do Presidente Fernando Collor à Lei Orgânica de Saúde e coordenando a $9^{a}$ Conferência Nacional de Saúde.

\subsection{Estratégias em prática}

A descrição do Movimento Sanitário em termos de diagnóstico, prognóstico, eventos e atores permite afirmar que a estratégia de caminho institucional estava norteando a ação dos atores do tal Movimento, encontrando um terreno especialmente propício no contexto da transição democrática. A seguir, acompanharemos uma seleção de episódios bastante emblemáticos que descrevem o repertório de ação acionado pelos atores. Analisaremos, no primeiro episódio, a tática, já observada no período anterior, de ocupação de cargos na administração pública. Na nova conjuntura, seu uso requereu articulações com os partidos da coalizão governamental, diferentemente da mesma tática adotada no regime militar, pela qual os sanitaristas aproveitavam-se das conexões pessoais para chegar a postos na administração pública. Iluminaremos, no segundo episódio, a convocação e organização da $8^{\text {a }}$ Conferência de Saúde, enquadrada, nessa tese, como tática de apropriação de espaço estatal para os fins do movimento. O terceiro episódio realçará a adoção pelo movimento uma forma organizacional não convencional, a Plenária Nacional de Saúde, durante a Assembleia Constituinte e que será 
importante vetor de ação política em torno do Legislativo, a saber, o lobby parlamentar. Por fim, veremos como os eventos do movimento e a ocupação de cargos animaram o processo do movimento na sua vertente municipalista que, fundou sob sua égide a organização de representação política dos secretários municipais de saúde.

O caráter específico da transição democrática direcionou nossa análise para as táticas dos atores do movimento relacionadas com a estratégia de caminho institucional. A outra estratégia, a de formação do campo profissional, não foi deixada de lado pelos atores, como veremos no capítulo seguinte, mas o quadro especialmente sensível de mudanças políticas deixou-a em segundo plano.

\subsubsection{Estratégia do caminho institucional}

3.3.1.1 Nos gabinetes do poder executivo: tática de ocupação de cargos no nível federal

No capítulo anterior, vimos que, no período entre 1974 a 1979, os ativistas do Movimento Sanitário puseram em prática a estratégia de caminho institucional, e que uma das táticas utilizadas foi a ocupação de cargos "por dentro" do Estado que permitia a realização, ainda que parcial, da proposta do movimento. Destacamos três ocorrências de ocupação de cargos: no nível federal, por meio dos cargos comissionados; no nível estadual, aproveitando a carreira de servidor público e, no municipal, ao ocupar os cargos de secretário ou dirigente municipal de saúde. Mostramos que essa tática era utilizada tanto pelos membros do Partido Comunista Brasileiro, quanto pelos militantes vinculados a outras vertentes da esquerda brasileira.

Os sanitaristas darão continuidade à ocupação de cargos na transição democrática da Nova República (1985-1989), tirando vantagem do novo contexto político, no qual uma parte da esquerda brasileira compunha a coalizão governamental que emergiu depois das eleições do primeiro presidente civil. Embora indireto, porque por meio da votação no Colégio Eleitoral, o pleito se apoiou num 
jogo competitivo entre a chapa da Aliança Democrática, composta pelo PMDB e a dissidência do PDS (Partido Democrático Social), a Frente Liberal, com as candidaturas de Tancredo Neves, para presidente, e José Sarney, para vicepresidente; o PDS apresentava a candidatura de Paulo Maluf. A chapa TancredoSarney derrotou a de Maluf, mas a tomada de posse pelo presidente que simbolizava a mudança foi impedida pelo seu falecimento, ainda em abril de 1985. Sarney assumiu em seu lugar, mantendo, no início do mandato, o gabinete escolhido por Tancredo. É nesse contexto que vários sanitaristas passaram a ocupar importantes cargos na administração pública setorial. Descreveremos em detalhes o caminho de Hésio Cordeiro à presidência da principal agência de saúde na época. Se, na conjuntura de um governo apoiado na coalizão de partidos, foi possível alcançar os cargos de maior importância, esse jogo dependeu das relações com os partidos da coalizão e do trabalho junto às suas bancadas estaduais para viabilizar a candidatura do militante diante das autoridades competentes.

A ocupação de cargos para os primeiros escalões do novo governo foi discutida e articulada nos bastidores do IV Encontro Municipal do Setor de Saúde e do III Encontro Nacional de Secretários Municipais de Saúde. Realizados em Montes Claros, em fevereiro de 1985, tais encontros entre os militantes e as organizações do Movimento Sanitário tiveram por objetivo discutir a conjuntura do recém-eleito governo civil (Goulart, 1996: 42). Hésio Cordeiro, candidato do movimento ao cargo da presidência do Inamps, foi autor do documento do evento, a "Carta de Montes Claros", que continha as diretrizes que visavam orientar a política nacional de saúde do futuro governo de Tancredo Neves. Logo depois, Cordeiro se incorporou à Comissão do Plano de Ação do Governo (Copag), grupo que elaborava $o$ as ações do novo governo.

A nomeação ao cargo da presidência do Inamps, uma autarquia federal, à semelhança dos ministérios, dependia do Presidente da República, e exigiu o trabalho de busca pelo apoio de várias bancadas estaduais dos partidos da coalizão governamental. Essa era a moeda reconhecida na negociação capaz de "apagar" o passado do ativista em franco conflito com os interesses dominantes no Inamps, agência responsável pela saúde dos contribuintes da previdência, que se utilizava do setor privado como o seu principal fornecedor de serviços. Diz-se, em tom de 
anedota, que o assessor de um dos concorrentes de Hésio Cordeiro ao cargo, representante do setor privado da Federação dos Hospitais Brasileiros (FBH), Francisco Bedusque Xavier, tentava dissuadir os deputados do apoio ao sanitarista, dizendo "Olha, você não pode apoiar o Hésio, porque no livro tal, tá aqui o livro, na página tal, ele diz que tem que estatizar o Ministério da Saúde. Ele é um comunista!" (Nogueira, entrevista, 1990).

De fato, Hésio Cordeiro fizera parte do clandestino PCB. Graduou-se pela Universidade Estadual do Rio de Janeiro, onde participou de uma experiência em saúde comunitária. No início dos anos 1970, ele foi um dos idealizadores do Instituto de Medicina Social, um polo de renovação do pensamento crítico e das formulações alternativas no campo da política de saúde (Buss, 1988). O médico também foi membro do Cebes e assumiu, entre 1983 e 1985, a presidência da Abrasco. A partir dessa posição que iniciou seu caminho à presidência do Inamps, ainda que antes tivesse sido ventilada a possibilidade de ocupar o cargo na CEME Central de Medicamentos (Noronha, entrevista, 1987-1988: 11).

A "ocupação" do Inamps foi articulada entre os militantes e se tornou objeto de uma verdadeira "campanha". Houve uma série de reuniões nas quais os ativistas discutiram a necessidade da aproximação com o PMDB, fizeram considerações sobre os potenciais concorrentes, elaboraram as táticas da ocupação das superintendências regionais do Inamps e da busca de apoio dos políticos (Noronha, entrevista, 19871988). Tratava-se de uma decisão coletiva que exigia um envolvimento político dos militantes:

\footnotetext{
Então a gente faz a reunião com Nelsão41, Hésio42, eu, Luís Humberto43, Eleutério ${ }^{44}$, Ardoni, Cavalheiro, prof. Guilherme ${ }^{45}$. Dessa reunião com o Waldir [Pires - Ministro de Previdência e Assistência Social] sai a tentativa de trabalhar as candidaturas de Hésio e do Prof. Guilherme como simultâneas. Muito bem, ai nesse momento a gente começou a desenvolver um lobby parlamentar, parlamentar no sentido de apoio a Hésio. A gente sabe que a coisa vem pela política (Noronha, entrevista, 1987-1988: 16).
}

\footnotetext{
${ }^{41}$ Refere-se a Nelson Rodrigues dos Santos.

${ }_{42}$ Refere-se a Hésio Cordeiro.

${ }^{43}$ Refere-se a Luis Umberto Pinheiro.

${ }_{44}$ Refere-se a Eleutério Rodrigues Neto.

${ }_{45}$ Refere-se a Guilherme Rodrigues da Silva.
} 
Esse caminho pela política significava trabalhar os apoios declarados dos deputados e, consequentemente, das bancadas estaduais, pois, embora ligado ao PMDB, Hésio não era um militante expressivo do partido ou político de projeção nacional. Seu "assessor da campanha", Ricardo Nogueira, sanitarista do Rio Grande do Sul, havia conhecido Hésio Cordeiro nas palestras proferidas na universidade, nas quais o ativista defendia o radical projeto - radical para os termos da época - do sistema universal de saúde. Nogueira trabalhava na secretaria municipal de saúde, em Pelotas (RS), no governo do PMDB, quando soube da candidatura de Cordeiro e se ofereceu para organizar o apoio. No primeiro impulso, seguiu a sua prática cotidiana: recorreu às associações de bairro e aos sindicatos de Pelotas com os quais vinha trabalhando. No segundo movimento, encaminhou a mobilização das federações e confederações dos trabalhadores no país:

\footnotetext{
Mas nós vimos que só esse apoiamento da área social, dos sindicatos, das confederações, das associações de bairro não bastava, tinha que ter um apoiamento partidário, político. Todo esse apoio obviamente que era político. Então nós mobilizamos o partido, mobilizamos a câmara de vereadores, aí partimos pra bancada do Rio Grande do Sul. A associação dos prefeitos, todas as prefeituras. Era uma campanha via telex, assim via Embratel, chegavam... Verdadeiros pergaminhos... (risos). De apoiamentos. E o Hésio se entusiasmava com aquilo. A partir daí que a gente fechou toda a bancada do Rio Grande do Sul, diz o Hésio: vem para cá pra articularmos o resto (Nogueira, entrevista, 1987-1988: 3).
}

A equipe de "assessoria parlamentar", da qual faziam parte, além de Nogueira, outros sanitaristas, como Paulo Buss, Arlindo Fábio Gómez de Sousa e José Noronha, foi conquistando o apoio nas bancadas do PMDB. Muitas vezes, apoio obtido a partir de um deputado em particular favorável ou sensibilizado com a causa do movimento, por exemplo, Luiz Humberto, da Bahia; Carlos Mosconi e José Luis Guedes, de Minas Gerais; ou Max Mauro, do Espírito Santo. Desse modo, a equipe angariava apoio estado a estado. Muitos desses contatos eram feitos via telex; outros percorrendo-se os gabinetes dos deputados.

Uma vez feito o trabalho com os deputados federais, chegava a vez do Senado, que, na época, segundo Nogueira, votava em bloco: “A partir do momento que o Fragelli [Presidente do Senado] assinou, ai não precisava mais pedir assinaturas. Todo mundo vinha atrás da gente pra assinar. Todos os senadores" (Nogueira, entrevista, 1987-1988: 14). 
Foi ao final de abril, em 1985, que Ricardo Nogueira e o presidente da Comissão de Saúde da Câmara Federal, Carlos Mosconi, entravam no Ministério de Previdência e Assistência Social para uma audiência marcada com o ministro da pasta, Waldir Pires. Levavam consigo uma lista de assinaturas de deputados individuais e das bancadas estaduais do PMDB e de todos os senadores que expressavam o apoio à candidatura de Hésio Cordeiro à presidência do Inamps (outro militante do movimento, Guilherme Rodrigues da Silva, havia desistido da candidatura). A audiência não resultou nem em apoio, tampouco em rejeição. $\mathrm{O}$ ministro precisava submeter a candidatura ao Presidente da República, a quem cabia a nomeação desse tipo de cargo.

Durante os anos em que ocupou o cargo, entre 1985 e 1987, Hésio Cordeiro, junto com a sua equipe, em boa parte composta por sanitaristas, expandiu as AIS, programa implementado pelo grupo anterior dos militantes do Movimento Sanitário inserido no Estado sob a liderança de Eleutério Rodrigues Neto, conforme vimos no capítulo anterior. Numa "coluna sanitária", Hésio Cordeiro e Ricardo Nogueira percorriam o país inúmeras vezes de modo a convencer os políticos locais a favor desse programa que visava ora construir ora fortalecer o setor municipal de saúde. O receio dos prefeitos da época era a possível instabilidade dos recursos do Inamps. Se a verba viabilizava a implementação dos serviços, as prefeituras, ao instalá-los, assumiriam o compromisso de fornecê-los (Nogueira, entrevista, 1987-1988: 15) e, consequentemente, por elas seriam cobradas pela população no momento da eleição, como lembra Nogueira:

Os prefeitos tinham muito medo. Eu me lembro que no Rio Grande dos Sul,
na minha cidade, Pelotas, (...) foi feita uma reunião pelo prefeito municipal
em 1985 com outros prefeitos e todos [estavam] contra as Ações Integradas
de Saúde. Fui eu e o José Temporão. E ele posteriormente pode confirmar
isso aqui. Fomos quase linchados pelos prefeitos (Nogueira, entrevista,1987-
1988: 12).

Apesar disso, o número de municípios envolvidos nas AIS cresceu de 112, em 1984, para 2.215, em 1986 (Escorel, 1998: 185).

Hésio Cordeiro e sua equipe foram também responsáveis pela implementação de mais um programa de caráter reformista, os, Sistemas Unificados e Descentralizados de Saúde (SUDS), em 1987. Os SUDS, de abrangência nacional, 
reiteravam os princípios da mudança já contidos nas AIS: a descentralização, o fortalecimento do setor público da saúde, a universalização e a equidade no acesso aos serviços de saúde, a integralidade dos cuidados assistenciais, a regionalização e integração de serviços e o desenvolvimento de instituições colegiadas (Lima; Fonseca; Hochman, 2005: 79; Noronha; Levcovitz, 1994: 88). À diferença das AIS onde os convênios eram firmados diretamente entre os munícipios e o Inamps, nos SUDS os convênios eram estabelecidos entre o Inamps e as Secretarias Estaduais de Saúde. Uma das razões para tal mudança era subordinar as superintendências do Inamps às secretarias estaduais de saúde, provocando um progressivo enfraquecimento da agência previdenciária de saúde, segundo o depoimento de um dos sanitaristas que conduziu esse processo no Inamps (Noronha, entrevista, 2004). Com o SUDS, a participação do setor público nas despesas do Inamps passou de 25,8\%, em 1981 (considerando-se a rede própria do Inamps, os serviços públicos e os hospitais universitários) para 45,2\%, em 1987. Enquanto a participação do setor privado contratado e conveniado diminuiu de $64,3 \%$ para $40 \%$, nos mesmos anos (Cordeiro, 1991: 106). ${ }^{46}$

Hésio Cordeiro não foi o único a ocupar cargo de direção no governo federal. Mencionemos brevemente mais dois ativistas pela relevância dos postos que assumiram e pela capacidade de indicar outros militantes para cargos. ${ }^{47}$ Eleutério Rodrigues Neto envolveu-se na elaboração da proposta do governo do candidato do PMDB para o setor de saúde, junto com outro integrante do movimento, José Temporão. O texto foi um verdadeiro patchwork de todos os outros documentos já elaborados pelo movimento, ainda que tenha sofrido uma adaptação necessária de modo a torná-lo comunicativo e claro para um público amplo (Temporão, entrevista, 1987-1988; Nunes, entrevista, 2005). Esse foi o pedido do coordenador do plano na parte do setor de saúde, deputado Carlos Sant'anna, já cogitado para ser o Ministro

${ }^{46}$ O SUDS perdurou até 1990, isto é, até a aprovação da Lei Orgânica de Saúde (LOS) e, ao longo de a sua vigência, enfrentou as resistências do setor privado e da burocracia do Inamps, principalmente quando os representantes do Movimento Sanitário foram depostos dos quadros dirigentes do MPAS e do Inamps. A continuidade dos SUDS foi garantida pelo envolvimento e pressão dos secretários estaduais e municipais de saúde (Escorel, 1998: 94; Noronha; Levcovitz, 1994: 94).

${ }^{47}$ Entre os sanitaristas que passaram a ocupar os cargos no Executivo estavam: José Saraiva Felipe, no cargo de Secretário dos Serviços Médicos do MPAS; Francisco de Assis Machado, no de Coordenação de Promoção de Saúde Individual, órgão da direção geral do Inamps; e Francisco Eduardo Campos, na coordenação da Secretaria de Recursos Humanos do MS (Cebes, 1985: 20). 
da Saúde. Uma vez indicado, convidou Rodrigues Neto para assumir o cargo de Secretário Geral do Ministério da Saúde, em 1985.

Sérgio Arouca ${ }^{48}$, por sua vez, que assumiu a presidência da Fundação Osvaldo Cruz (FioCruz) em 1985, foi um dos primeiros militantes do Movimento Sanitário e um dos mais carismáticos. A tese de doutorado de Arouca, “O Dilema Preventivista", é considerada um dos principais fundamentos teóricos do Movimento Sanitário (Menicucci, 2007: 171). Militante do PCB, como professor do Departamento de Medicina Preventiva na Unicamp coordenou uma experiência de saúde comunitária em Paulínia, onde pôde colocar em prática a sua visão da saúde. Banido da Unicamp pelo reitor, em 1975, foi acolhido na Escola Nacional de Saúde Pública como coordenador do Programa de Estudos Socioeconômicos em Saúde (PESES), que agregava pesquisadores e professores de perfil reformista, como vimos no capítulo dois.

A indicação de Sérgio Arouca para o cargo da presidência do maior instituto de pesquisa de saúde ${ }^{49}$, o Fiocruz, sediado no Rio de Janeiro, repousou no mecanismo de busca de apoio da bancada carioca do PMDB, acompanhada pelos telegramas de apoio mandados de diferentes instituições ao Ministério da Saúde, a quem cabia a indicação de um nome. A campanha de Arouca durou mais de cinco meses, durante a qual o sanitarista deixou de fora o então Presidente da Fiocruz, major Guillardo Martins Alves, apoiado por um senador da Bahia com acesso a Sarney e outro candidato que tinha suporte de um deputado do PMDB. O coordenador da campanha pró-Arouca, Arlindo Fabio Souza Gomes, buscou o suporte da bancada do PMDB fluminense, que custou a ser conquistado; era um apoio volátil, confirmava-se para recuar em seguida. Três dias antes da nomeação, Arlindo participou do encontro do partido no Centro do Rio de Janeiro, durante o qual conquistou o apoio final da bancada, que constituía para o Ministro de Saúde, Carlos Sant'anna, o argumento cabal para negociar a nomeação com o presidente Sarney (Nunes, entrevista, 2005).

\footnotetext{
${ }^{48}$ A trajetória de Sérgio Arouca foi objeto de alguns trabalhos biográficos. Entre eles, destaca-se o projeto Memória e Património da Saúde Pública no Brasil: a Trajetória de Sério Arouca - PRODOC 914 BRA 2000 - da Unesco, que resultou em dezenas de entrevistas e três relatórios disponíveis ao público.

${ }^{49}$ A campanha de Arouca se baseia nos depoimentos de Carlos Morel, Cristina Tavares, Arlindo Fabio Souza Gomez e Luís Fernando Ferreira (Relatório, 2005b).
} 
A Fiocruz era uma instituição importante e Arouca foi responsável por algumas mudanças relevantes, como a reintegração dos pesquisadores cassados na ditadura; a criação da Casa de Oswaldo Cruz, voltada para o estudo da história da ciência no Brasil, e de um centro Politécnico orientado para o ensino médio; o direcionamento de maiores investimentos para a produção de vacinas; a elaboração de pesquisas como, por exemplo, a da tecnologia para exame de AIDS e o isolamento, pela primeira vez, do vírus no Brasil (Relatório 2005b: 32-33).

Arouca, Rodrigues Neto e Cordeiro não só contribuíram para o desenvolvimento de ações alinhadas com a proposta do movimento, mas conseguiram por em prática uma nova tática, a de apropriação de espaço estatal, permitindo ao movimento dotar a sua proposta de alta legitimidade. A Conferência Nacional de Saúde, evento até então reservado à burocracia estatal, em sua oitava edição, foi aberto à ampla participação. Com efeito, a realização do evento, sob a coordenação do Movimento Sanitário, resultou no aumento de atores ligados à causa da Reforma Sanitária e na legitimação do projeto sustentado pelo movimento, num contexto político especialmente sensível às propostas, o da elaboração de uma nova constituição para o país.

\subsubsection{Mobilização no Ginásio de Brasília: 8a Conferência Nacional de Saúde:}

A ideia de estender a participação na Conferência Nacional de Saúde ${ }^{50}$ a amplos e diversificados segmentos da sociedade, um evento até então restrito à burocracia estatal e políticos (Escorel; Bloch, 2005), foi compartilhada numa reunião, durante um almoço, da qual fizeram parte o então Ministro de Saúde, Carlos Sant'anna, do PMDB baiano; Eleutério Rodrigues Neto, sanitarista no cargo de Secretário Geral do Ministério de Saúde; e Sérgio Arouca, sanitarista que ocupava, na época, o cargo da presidência da Fiocruz. ${ }^{51} \mathrm{O}$ clima tenso da reunião devia-se ao

\footnotetext{
${ }^{50}$ A descrição das Conferências de Saúde, com o foco nas realizados na vigência do SUS, os seus principais atores e debates encontra-se em Escorel e Bloch (2005).

${ }^{51}$ Relato baseado no depoimento da sanitarista Fabíola Aguiar Nunes (Nunes, entrevista, 2005).
} 
impasse instalado no Movimento Sanitário e que estaria comprometendo a carreira do político baiano. Sant'anna não era um militante do movimento, todavia, compartilhava de suas ideias e convivia com alguns dos ativistas. Por força desses contatos, havia se tornado autor de uma lei, aprovada pelo Congresso, que passava ao Presidente da República a prerrogativa de transferir, em um momento oportuno, o INAMPS ao Ministério de Saúde. Esse era um dos objetivos elementares do movimento, defendido desde o $1^{\circ}$ Simpósio, em 1979, por meio do qual seriam instalados o comando único e o controle sobre o setor de saúde, que, na visão do movimento, estava nas mãos da burocracia inampsiana articulada com o setor privado de medicina.

Porém, apesar desse potencial legal, o sanitarista Hésio Cordeiro, contrariamente a sua conhecida posição a favor da unificação, uma vez no cargo, recuou. Alegava que era preciso avançar as reformas parciais - as AIS -, possibilitadas pelo poder e pelos recursos que o Inamps oferecia, ao invés de entregálas à lentidão da máquina administrativa do Ministério da Saúde, o que poderia frear a sua implementação (Cordeiro, entrevista, 2004) Durante a reunião, Sant'anna deixava claro que havia assumido publicamente essa lei como a sua bandeira política e que, naquele momento, estava diante da necessidade de uma tomada de decisão, razão que o fazia querer saber qual era a posição dos presentes. O impasse foi rompido na hora por Arouca, quem sugeriu que se fizesse uma parte da unificação, incorporando a Central de Medicamentos (CEME) ao Ministério da Saúde, bem como propôs a legitimação da transferência do Inamps pela voz da sociedade. O espaço dessa legitimação seria, apontava Arouca, a Conferência Nacional de Saúde.

Além do peso da tradição setorial como um evento da burocracia estatal, pois a Conferência estava em sua oitava edição, ampliar a participação significava partilhar do princípio, pouco difundido na época, de que os leigos têm algo de relevante a dizer a respeito da diversidade de temas ligados ao setor de saúde. Carlos Sant'anna comprou o desafio de enfrentar possíveis resistências no Planalto e nos corredores do Ministério, entregando o fardo da coordenação a Sérgio Arouca. Isso porque convocar centenas de delegados e coordenar os debates, no universo tão heterogêneo como se almejava, estava longe de constituir uma tarefa óbvia nessa primeira experiência. Dessa tarefa, encarregaram-se os sanitaristas da ENSP (Escola 
Nacional de Saúde Pública), da Fiocruz e da Abrasco (Belisário, 2002: 271) que percorreram o país, reunindo entidades, associações e grupos em encontros para a discussão e divulgação do projeto do Movimento Sanitário. Ary Carvalho de Miranda, pesquisador da ENSP, por exemplo, fez uma reunião de três dias num convento com 38 sindicatos rurais do Maranhão (Relatório 2005b). Foi possível realizar as pré-conferências em todos os estados e, em quatro deles, Minas Gerais, Paraná, Sergipe e Pará, foram organizados os encontros municipais preparatórios ${ }^{52}$ (Franco Netto; Abreu, 2009: 149). Um dos importantes financiadores da $8^{\text {a }}$ Conferência, nas suas etapas preparatórias, foi o Inamps, dirigido por Hésio Cordeiro, que assinou uma série de convênios com a Fiocruz para viabilizar os recursos para as viagens e reuniões prévias (Cordeiro, entrevista, 2004).

O fardo da coordenação possuía uma segunda face, que consistia no poder de atribuir a linha política ao evento. A difusão dos postulados do Movimento Sanitário e as discussões ao longo da preparação da Conferência deram-se com base num texto da Abrasco. ${ }^{53}$ A entidade criou uma Comissão Especial de Políticas de Saúde, coordenada pela sua vice-presidente, Sonia Fleury, que elaborou o documento intitulado "Pelo Direito Universal à Saúde", cuja tiragem de 17 mil exemplares foi amplamente distribuída em reuniões e eventos nos estados. Esse processo preparatório levou à Brasília quatro mil participantes, dentre eles mil delegados (Relatório da 8a Conferência, 1986), contra 400 participantes da edição anterior da Conferência. Além do número expressivo, diversificavam-se os atores da sociedade civil que se vinculavam à causa da Reforma Sanitária. O fruto concreto da legitimação foi o Relatório Final da 8a Conferência Nacional de Saúde, cujas teses foram aprovadas no Plenário da Conferência e que simbolizaria, daquele momento

\footnotetext{
${ }^{52} \mathrm{~A}$ mobilização dos atores nos níveis estadual e municipal para a $8^{a}$ Conferência exigiria um estudo mais aprofundado, mas as Comissões Interinstitucionais de Saúde, instituições obrigatórias dos convênios das Ações Integradas de Saúde, implementadas a partir de 1983, e que tinham entre os seus membros, necessariamente, representantes da comunidade, podem ter sido canais importantes para tanto (Carvalho, entrevista 2012).

${ }^{53}$ A elaboração deste documento contou com o financiamento por meio do "Acordo da Cooperação Técnica" com a OPAS, que já financiara uma parte de atividades voltadas para a formação profissional do Movimento Sanitário nos anos 1970. Como veremos no capítulo seguinte, a possibilidade de desenvolvimento de projetos com um grau de autonomia que o "Acordo" oferecia pela sua forma organizacional foi também aproveitada pelos sanitaristas ao longo da década de 1980. Roberto Nogueira, um dos integrantes do "Acordo" mediou e participou da elaboração do documento pela Abrasco (Castro, 2008: 97).
} 
em diante, a força do movimento não mais sanitário, pois esse termo era ligado a certos grupos e organizações, mas do movimento pela Reforma Sanitária ou movimento pela democratização da saúde (Paim apud Rodrigues Neto, 2003: 34). Vale notar que o setor privado se negou a participar da $8^{a}$ Conferência por não conseguir a quota demandada para seus delegados, e suas principais entidades, tais como, a Federação Nacional dos Estabelecimentos de Serviços de Saúde (Fenaess), a FBH, a Associação Brasileira de Medicina de Grupo e Empresarial (Abramge) organizaram o I Congresso de Entidades Não-Governamentais do Setor Saúde com o objetivo de reafirmar a importância dos serviços de saúde não-governamentais (Pereira, 1996).

A $8^{a}$ Conferência, talvez, em parte por não incluir o setor privado de medicina, foi capaz de gerar uma proposta comum a todos os seus participantes, entre os quais se encontravam atores de peso na política nacional. Ao fazer o uso inusitado do espaço coletivo da burocracia estatal, numa tática de apropriação de espaços estatais para os fins do movimento, os sanitaristas legitimavam seu projeto e, com base nessa legitimação, colocavam as autoridades diante de uma situação nova. O coletivo da Conferência postulava a continuidade do processo - a efetivação das diretrizes por ela consensuadas -, sugerindo, para tanto, a forma de encaminhamento ao indicar, no Relatório da 8a, a criação do Grupo Executivo para a implementação da Reforma Sanitária, a ser convocado pelo Ministério da Saúde (MS). Diante do silêncio do ministério, a Abrasco tomou a dianteira, conduzindo uma reunião, em 5 de julho de 1986, na qual os representantes do MS e do Inamps se comprometiam a convencer os respectivos ministros a convocar a Comissão Nacional de Reforma Sanitária - CNRS54 (Rodrigues Neto, 2003: 49). Devido à resistência do MS55, foi possível criar um espaço de caráter consultivo composto paritariamente pelos representantes governamentais e pela sociedade civil, e cuja secretaria executiva funcionou em tempo integral na Fiocruz. Tal secretaria, conduzida por três sanitaristas, Arlindo Fábio Gómez de

\footnotetext{
${ }^{54}$ A Comissão Nacional da Reforma Sanitária foi composta por 22 representantes no total, entre os quais, a Central Única dos Trabalhadores (CUT), a Confederação Nacional dos Trabalhadores (CGT), a Confederação dos Trabalhadores da Agricultura (Contag), a Confederação Nacional dos Médicos (FNM), e a Confederação Nacional de Associações de Moradores (Conam), o Conass, o Conasems, a Confederação das Misericórdias, a Federação Brasileira dos Hospitais (FBH), centrais patronais (CNI, CNC, CNA) (Gerschman, 2004: 56; Menicucci, 2007: 187).
}

${ }_{55} \mathrm{O}$ ministro aliado já havia se afastado do cargo para disputar a eleição para a Constituinte. 
Sousa, Eleutério Rodrigues Neto e Luiz Cordoni Junior, era encarregada da elaboração dos documentos e estudos, alimentados pelos conteúdos das Conferências temáticas que ocorreram depois da $8^{\text {a. }}$.

A Comissão cumpriu seu objetivo de apresentar as sugestões ao Ministério da Saúde, e, aproveitando a conjuntura, entregou um documento especial à Assembleia Constituinte, que acabava de ser instalada. A "Proposta para o Componente Saúde da Nova Constituição Brasileira" continha o texto de lei que aprofundava e atualizava, "sem alterar a direção - das conclusões da $8^{\text {a }}$ Conferência Nacional de Saúde, as quais serviram de base para todos os trabalhos da CNRS" (CNRS, 1987: 5), embora não contivesse a tese da estatização. A Comissão Nacional da Reforma Sanitária (CNRS) foi autora também da "Proposta de Conteúdo para uma nova lei do Sistema Nacional de Saúde". Ambos os documentos foram publicados e distribuídos em 20 mil exemplares à imprensa, aos órgãos de serviços públicos, universidades, entre outros.

Em pouco mais de dois anos (de novembro de 1984 a março de 1987), o movimento gerou ou participou da elaboração de uma série de documentos políticos de alta circulação, tanto em termos de tiragem, quanto das arenas políticas que atingiam, nos quais estava expressa a sua proposta de saúde. Carregava a marca do movimento o documento apresentado pela Comissão de Saúde da Câmara dos Deputados ao então candidato à presidência, Tancredo Neves. O movimento foi autor da secção sobre o setor de saúde no programa do governo desse candidato, bem como coordenou o texto da CNRS, entregue à Assembleia Constituinte. O processo de elaboração da nova Constituição exigiu o uso de uma outra tática, o lobby parlamentar, que se apoiou em um formato organizacional não convencional para o Movimento Sanitário - a Plenária Nacional (de Entidades) de Saúde.

\subsubsection{A Plenária Nacional de Saúde: lobby parlamentar do Movimento Sanitário}

A convocação da Assembleia Constituinte no período da transição democrática constituiu uma oportunidade política de ação para os movimentos e organizações da sociedade civil no Brasil que, entre novembro de 1986 e setembro de 
1988, organizaram 225 diferentes eventos de ação coletiva. entre os quais podem ser citados os de maior frequência: as reuniões e articulações entre os movimentos, as caravanas à Brasília, o lobby parlamentar, as manifestações, as demonstrações e os comícios (Brandão, 2011: 81 e 83). O Movimento Sanitário constituiu a Plenária Nacional de Saúde, também chamada de Plenária Nacional de Entidades de Saúde, nome que realça seu caráter articulador, em um formato organizacional capaz de agregar sob a sua coordenação mais de 160 entidades para fazer lobby parlamentar em prol do projeto de saúde do Movimento Sanitário durante a Constituinte ${ }^{56}$ Não se trata aqui de estabelecer a relação causal entre a atuação da Plenária e o desenho que o SUS adquiriu na proclamação da Carta Magna, e sim de realçar as formas de ação acionadas pelos atores, tanto aquelas que foram possibilitadas pelo desenho institucional da Constituinte, quanto outras que os atores acreditavam ser eficientes e adequadas naquele contexto.

A Plenária, constituída por iniciativa do Cebes e da Abrasco, em maio de 1987, dois meses após o início dos trabalhos da Constituinte, concentrou as mobilizações do movimento no período. O último grande evento do movimento havia ocorrido em março de 1987. O V Encontro Municipal do Setor de Saúde, organizado junto com o IV Encontro dos Secretários Municipais, reuniu mil pessoas, sendo o palco de articulações e compartilhamento das atividades em curso dos atores do movimento: foi criada uma comissão para fundar o Conselho Nacional de Secretários Municipais de Saúde; a Diretoria Nacional do Cebes deliberou pela participação mais ativa da entidade mediante a organização da Comissão Nacional do Cebes para Mobilização Popular pela Saúde e Reforma Sanitária; Hésio Cordeiro, no cargo de Presidente do Inamps, falou sobre os SUDS e os representantes municipais na CNRS (Goulart e Nelson Rodrigues) fizeram circular as informações sobre o andamento dos trabalhos (Goulart, 1996: 44).

O Encontro estava permeado por expectativas em relação à Assembleia Constituinte, a qual significava, para os atores do Movimento Sanitário, a oportunidade de mudar diametralmente os preceitos da Lei maior em relação à

\footnotetext{
${ }^{56} \mathrm{O}$ processo e os bastidores das lutas travadas na Constituinte pela ótica de um ator do Movimento Sanitário encontram-se no livro de Eleutério Rodrigues Neto (2003). Para a reconstituição do passo a passo das discussões sobre o setor de saúde nas quatros etapas regimentais da Assembleia Nacional Constituinte, ver a dissertação de mestrado de Fernando Gonçalves Marques (2010).
} 
saúde: torná-la um direito social e, com isso, acabar com o sistema de saúde pautado nas contribuições previdenciárias; unificar o comando, antes disperso em diversas agências públicas; tornar o Estado o responsável e condutor do setor como um todo; garantir a descentralização até o nível municipal pautada na participação da comunidade; e restringir o papel do setor privado de saúde, até então, o principal fornecedor do Estado e receptor dos recursos públicos. Esses postulados confrontavam os interesses de outros atores no setor, tanto estatais quanto públicos. Desse modo, o resultado das deliberações da Constituinte sobre o setor de saúde não estava definido. 57

A Plenária Nacional de Saúde assumiu um formato organizacional que permitia coordenar a ação coletiva dos mais diversos atores que a compunham: não era formalizada em uma entidade à qual o acesso seria restrito por algum tipo de exigência formal. Pelo contrário. Qualquer um podia participar das reuniões, debater e fazer parte das ações da Plenária no Congresso junto aos políticos e partidos. Isso porque, embora operacionalizada pela secretaria executiva 58 e possuísse a Coordenação, a Plenária propriamente dita, como a mobilização de entidades vinculadas a um projeto comum, acontecia por meio de um conjunto de atividades que mesclavam o lobby parlamentar com as reuniões de mobilização.

A Plenária Nacional de Saúde se enquadrava na forma de mobilizar, organizar e legitimar a participação popular durante a Constituinte. A partir de dezembro de 1985, antes da Assembleia Nacional Constituinte (ANC), portanto, começaram a ser criados os comitês e as plenárias em estados para discutir a participação popular e, poucos meses depois, seguiu-se uma sequência de reuniões do Plenário Nacional Pró-Participação Popular na Constituinte (Whitaker et al., 1989:.46). Tratava-se de uma mobilização ágil e aberta, orientada pelas necessidades e pelo andamento do processo político (e não por um estatuto), capaz de consensuar as diretrizes sobre a participação, bem como de enviar a sua representação no dia da instalação da ANC

\footnotetext{
${ }^{57} \mathrm{~A}$ análise do perfil dos constituintes realizado por um dos militantes do movimento indicou a presença de apenas doze médicos envolvidos com a política da saúde de um total de 58 parlamentares cujas profissões eram ligadas à saúde (Rodrigues Neto, 2003: 58).

${ }^{58}$ A secretaria executiva era gerenciada pelos ativistas do movimento, como Eleutério Rodrigues Neto, Samara Nitão, Thiers Ferreira e Jacinta de Fátima Senna da Silva e se reunia semanalmente num escritório cedido pelo Conselho Federal de Medicina em Brasília (Silva, apud BRASIL/MS/SEGEP, 2006: 58).
} 
para apresentar as propostas de participação popular (Brandão, 2011: 147). Com isso, foram contempladas pelo Regimento Interno da ANC as seguintes regras da participação popular: a inclusão do dispositivo de emendas populares; as audiências públicas nas subcomissões; a possibilidade de assembleias legislativas, câmaras de Vereadores, tribunais e entidades representativas de segmentos da sociedade enviarem sugestões às comissões e à Presidência da ANC; a publicidade das votações, através da regulamentação da presença da sociedade civil nas galerias do Plenário e da exigência de que as matérias constitucionais fossem votadas pelo processo nominal, e não por voto secreto. Resultado da mobilização da sociedade civil em prol da participação popular na Constituinte em aliança com alguns deputados progressistas, esse desenho foi posto em funcionamento e aproveitado amplamente por diversos movimentos sociais e entidades: só o trabalho inicial de subcomissões e comissões temáticas contou com quase duas centenas de audiências públicas e 974 especialistas e representantes de entidades foram ouvidos pelos constituintes, apresentando as suas sugestões (Brandão, 2011: 147). A Plenária Nacional da Saúde também seguia essas regras:

\footnotetext{
Eram varias estratégias, nos reunimos com líderes de partido, [havia] reuniões com a comissão de saúde, que era a comissão de saúde, seguridade e meio ambiente, audiências públicas gerais e temáticas. Tínhamos reunião com os deputados da comissão, reunião com o presidente da comissão, com o relator, tinha reunião com toda a comissão. (...) Todas as pequenas reuniões ou grandes reuniões das comissões, todas as atividades [para as quais] que o congresso chamava, nós participávamos ou para colocar nossas ideias, ou com grande número de pessoas para acompanhar as discussões (Silva, entrevista, 2009).
}

A última frase da secretária executiva da Plenária Nacional de Saúde, Jacinta da Silva, mostra justamente a forma de atuação viabilizada pelo regulamento da Assembleia Constituinte e que exigia grande número de pessoas: as portas abertas das audiências públicas que permitiam a presença de um público numeroso. Essa participação em massa era viabilizada pela chegada à capital, em momentos nevrálgicos e diante da convocação da coordenação da Plenária, das caravanas, ou seja, dos coletivos das entidades e ativistas ligados à Plenária. Seus participantes preenchiam os espaços regulamentados da participação popular, e também colocavam em prática outro tipo de ação, a qual consistia na pressão junto aos 
deputados e vocalizadores, isto é, aqueles que, em função do cargo ocupado, possuíam maior capacidade de influenciar a posição de outros deputados.

A composição suprapartidária do movimento ajudava nesse lobby. Cada grupo se dirigia aos gabinetes daqueles parlamentares com os quais tinha afinidade partidária, e essas pressões estavam permeadas pela leitura atenta do andamento dos trabalhos da Constituinte, expondo os entraves encontrados e as resistências a serem superadas. A coordenação e a secretaria executiva da Plenária se encarregavam de preparar um material comum a todos: eram forjados os argumentos, definidos os alvos da pressão, criados os alertas sobre as oportunidades e as ameaças ao processo, bem como elaborados os modelos de cartas de apoio que deveriam ser apresentadas a deputados e os comunicados a serem divulgados na imprensa local. Os deputados pressionados em Brasília eram frequentemente abordados em seus próprios estados, onde passavam uma parte da semana (Barros, entrevista, 2009), pela base estadual. Assim, o lobby funcionava em dois níveis. De um lado, o deputado constituinte era visitado pela base estadual, o que poderia significar, em termos de barganha, a continuidade do apoio eleitoral, ou a promessa do apoio nas eleições seguintes. Por outro, ao chegar em Brasília, percebia esse coletivo ampliado e organizado em nível nacional, mobilizado nas dependências do Congresso, batendo nas portas dos gabinetes e mostrando sua força numérica nas audiências públicas e nas próprias reuniões, realizadas no Congresso.

O recurso a diversas táticas e suas combinações fica claro no seguinte depoimento:

Tínhamos várias estratégias combinadas, tinha um momento que o movimento estadual, participante da Plenária, ia fazer convencimento aqui no Congresso e fazia também no estado, porque havia a necessidade de ter o movimento articulado no estado, porque também eles faziam a relação de mobilização e discussão no estado, com parlamentares do estado, durante o processo constituinte e durante a formulação discussão aprovação de leis ordinárias, a Lei 8.080 e a 8.142. Por isso que eu te digo, eram estratégias combinadas, às vezes no período de uma semana, todas as estratégias eram realizadas, a discussão na comissão, a visita e discussão nos gabinetes, a discussão com os líderes. Em alguns momentos nós nos reunimos com as lideranças dos partidos, às vezes dois ou três partidos, era determinado pela conjuntura do momento, às vezes a gente tinha que atuar apenas em uma banca, numa bancada de determinado partido, porque a ideia a ou b a resistência era daquele partido, daquela bancada, a discussão argumentativa, política era com aquele segmento e o trabalho corpo a corpo, agente trabalhava no conjunto da liderança, da liderança formal do partido, 
e as lideranças de vocalização, porque tinham as lideranças que não era a formal dos partidos. Nós tínhamos que mapear estas pessoas (Silva, entrevista, 2009).

Os materiais da Plenária Nacional de Saúde eram também transmitidos aos seus integrantes nos estados, que tinham compromisso de difundi-los de forma ampla em sua área de atuação; as entidades da Plenária com a estrutura federativa faziam o mesmo entre suas associadas (Barros, 2009, entrevista). A circulação constante da informação atualizada e as táticas pontuais de ação ajudavam a estabelecer os vínculos entre aqueles que se identificavam como partes do movimento pela Reforma Sanitária. Os vínculos se tornavam visíveis nas reuniões da Plenária, realizadas no próprio Congresso, das quais participavam os militantes que chegavam à Brasília por meio das já mencionadas caravanas. Num espaço aberto a manifestações e debates, os atores debatiam o andamento dos trabalhos na Constituinte. Uma mobilização da Plenária podia reunir entre 100 e 400 pessoas (capacidade máxima do auditório Nereu Ramos), e sua composição em termos de entidades e ativistas variava sem anular a sua legitimidade, o que evidenciava seu caráter pouco formalizado, aberto tanto para participar quanto para assistir às sessões. A Coordenação da Plenária costumava afixar o comunicado no Congresso, avisando às comissões da Constituinte que "a Plenária tá acontecendo ali", segundo Silva (entrevista, 2009). Vários deputados apareciam, especialmente quando a sua base estadual estava reunida (Silva, entrevista, 2009).

A Plenária foi responsável pelo encaminhamento da emenda popular de saúde, na qual é possível capturar o leque dos atores envolvidos. Se as assinaturas não alcançaram um número alto - foram 54.133, contra mais de um milhão na emenda referente à reforma agrária -, o número de entidades foi de longe o mais expressivo de todos: são referidas 122. Enquanto a maioria ficou com o número mínimo necessários de três entidades, a emenda de saúde foi encaminhada por 160, sendo campeã nesse aspecto (Whitaker, 1989: 152). Entre os assinantes, encontravamse as Plenárias de Entidades e Movimentos de Saúde estaduais (São Paulo, Rio Grande do Sul e Paraíba), os Movimentos Populares de Saúde, os Conselhos de Saúde de vários bairros de São Paulo, as centrais sindicais, as federações, os sindicatos, as associaç̃oes de trabalhadores de saúde, as entidades científicas e os 
partidos políticos. A emenda foi apresentada na Comissão de Sistematização da Assembleia Nacional Constituinte por três emblemáticos militantes do movimento: Sérgio Arouca (como presidente da Fiocruz), Guilherme Rodrigues dos Santos (como professor da USP) e Eduardo Jorge, médico sanitarista da Secretaria Estadual de Saúde e deputado Federal Constituinte pelo PT-SP (Arouca, 1988, 43-45).

Na proclamação da Constituição, em outubro de 1988, foi aprovada, pela primeira vez na história do país, a universalização do acesso a todos os serviços de saúde em termos de um direito do cidadão e do dever do Estado, organizada num sistema nacional único de saúde, descentralizado e pautado na participação dos usuários no processo da elaboração da política. A tese da estatização progressiva presente no Relatório da $8^{a}$ Conferência Nacional de Saúde e na emenda popular perdeu nos embates da Constituinte, mas o setor privado ficou com o papel de fornecedor "complementar" de serviços públicos ao invés da sua almejada igualdade de tratamento com os serviços públicos (Marques, 2010: 53). A Plenária Nacional de Saúde continuou ativa após a proclamação, principalmente na aprovação da Lei Orgânica da Saúde. Depois, aos poucos, foi se perdendo sua capacidade de mobilização, e as últimas articulações datam de 1997. Sua forma organizacional de pouca formalização, força numérica e rápida capacidade de mobilizar foi adotada, em meados dos anos 1990, por outro conjunto de atores do movimento pela Reforma Sanitária, num claro exemplo do aproveitamento do repertório que já era próprio do Movimento Sanitário. Esse episódio será apresentado no quinto capítulo.

3.3.2.4 O Conasems: ocupação de cargos, eventos e organização de representação política

Uma das organizações participantes da Plenária era o Conselho Nacional de Secretários Municipais de Saúde, uma organização fundada em 1987 pelos militantes do movimento que ocupavam cargos nas secretarias municipais de saúde. No capítulo anterior, acompanhamos como o grupo de sanitaristas adotou a tática de ocupação de cargos no nível municipal, possibilitada pela vitória do partido da oposição ao regime militar em algumas prefeituras. Concomitantemente, os 
militantes começam a promover os Encontros do Setor Municipal de Saúde, eventos organizados pelo poder público, mas que reuniam ampla diversidade de atores envolvidos nessas primeiras experiências de expansão dos serviços municipais de saúde. Nesta seção, acompanharemos os desdobramentos dessa tática, que continuou após as eleições de 1982, em termos de mobilização e de organização da ação coletiva. O processo que retrata a ação dos militantes do Movimento Sanitário no papel de secretários municipais de saúde mostra como a escolha de uma forma do repertório organizacional - uma associação nacional dotada da estrutura federativa assentada nas entidades estaduais e com forte capacidade de mobilização - permite a criação de pontos de acesso ao Estado e torna-se um canal de ação política.

Se após as eleições de 1976, há registro de algumas secretarias "ocupadas" pelos sanitaristas [Campinas, Niterói, Londrina, Piracicaba, Sorocaba, Guarulhos, São José dos Campos, Belo Horizonte (Carvalho, entrevista, 2012)], nas eleições seguintes, as de 1982, nas quais os partidos de oposição ao regime militar ganharam em mais municípios, nota-se o aumento das oportunidades de inserção para os militantes. Entre as cidades nas quais a oposição venceu, encontravam-se: São José dos Campos, Santos, Diadema, Santo André, Campinas, Piracicaba, Itu, Uberlândia etc. (Carvalho, entrevista, 2012). Essas eram as cidades pioneiras na implementação de amplos serviços municipais de saúde à população em geral. A partir de 1983, com a introdução das Ações Integradas de Saúde, pelos sanitaristas no nível federal, a implementação dos serviços municipais podia ser viabilizada também mediante o repasse dos recursos federais. Bauru foi uma das cidades ocupadas pelos sanitaristas no estado de São Paulo, depois das eleições municipais de 1982. Seu caso foi bem documentado e mostra como a oportunidade de trabalhar em um novo modelo de saúde trouxe sanitaristas de fora da cidade. O caso explicita também como a chegada das AIS mudou o quadro financeiro no setor.

Bauru, cidade de médio porte na época, situada no centro geográfico do estado de São Paulo, foi conduzida pelos governos aliados ao regime militar até o pleito de 1982, quando o PMDB ganhou as eleições. A chapa composta pelo prefeito Edison Bastos Gasparini, ex-militante do Partido Comunista Brasileiro (PCB), e o 
vice, Tugo Angerami, do novo Partido dos Trabalhadores59, priorizou a educação, a saúde e a participação popular (Capistrano Filho; Pimenta, 1988: 20) e nomeou David Capistrano Filho, um dos líderes do Movimento Sanitário, ao cargo de secretário na Secretaria de Higiene e Saúde.

Até 1983, os serviços municipais de saúde de Bauru resumiam-se, à semelhança de outras cidades, a um pronto socorro e cinquenta funcionários. Isso não significava a ausência completa de equipamentos de saúde. Esses existiam sob a responsabilidade da Secretaria Estadual de Saúde e o Inamps60, ainda que insuficientes sobretudo na matéria de cuidados primários e programas voltados a grupos de necessidades especiais. A nova gestão municipal de saúde escolheu a periferia como área de foco para sua atuação, instalando, em quatro anos, uma rede de 13 postos em praticamente toda a periferia com os serviços de clínica, pediatria, ginecologia e odontologia. Foram criados o Serviço de Odontologia, o Programa Municipal de Saúde dos Trabalhadores, o Ambulatório de Fonoaudiologia e o Banco de Leite Materno. O quadro dos funcionários cresceu de 50 a 300 servidores (Capistrano Filho; Pimenta, 1988: 49). A decisão do governo municipal de priorizar a saúde resultou no crescimento de recursos para o setor, que subiu de 4,59\% em 1984 para 11,33\% em 1987. Em 1985, chegaram os primeiros repasses vinculados às AIS, que representaram naquele ano 20\%, mas que em 1987 equivaleram à $47 \%$ do orçamento municipal, custeando a expansão da rede do atendimento primário. (Capistrano Filho; Pimenta, 1988: 45).

Todo esse processo foi fruto do trabalho da equipe de David Capistrano Filho, composta tanto pelos profissionais de fora da cidade, que se incorporaram à experiência de Bauru pela possibilidade de implementar novas formas de tratar da saúde, quanto pelos recém-formados, sem experiência prévia política ou profissional. Os primeiros trouxeram novas formas de atuação nas áreas de saúde do trabalhador, epidemiologia, administração entre outros. Na saúde mental, por exemplo, o psiquiatra Roberto Tykanori, importante militante da Reforma Psiquiátrica,

\footnotetext{
${ }^{59}$ Edison Bastos Gasparini morreu oito meses depois da posse, e Tugo Angerami assumiu o cargo do prefeito (Capistrano Filho; Pimenta, 1988: 20).

${ }_{60}$ Pertenciam ao Inamps um Posto de Atendimento médico com 64 médicos e à Secretaria Estadual de Saúde, seis Centros de Saúde, um laboratório regional do Instituto Adolfo Lutz (IAL), um hospital geral, uma maternidade do governo do estado e dois hospitais especializados.
} 
implementou um dos primeiros serviços substitutivos do manicômio. As equipes de trabalho que incorporavam os recém-formados investiam muito no constante trabalho de formação e discussão, que acontecia em reuniões periódicas chamadas de Educação Continuada, nas quais se discutia o cotidiano do trabalho à luz de cuidados com os usuários, buscando descontruir o atendimento burocratizado. A preferência pelos profissionais de fora provocou a oposição dos médicos da cidade. Reunidos em assembleia da Associação Paulista de Medicina, em 1984, deram ao então secretário David Capistrano Filho, o título de "persona non grata", acusado de ser de fora do município e não valorizar os médicos da cidade (Pimenta, 2006: 97).

Bauru ilustrava a realidade de um conjunto de municípios do estado de São Paulo, tanto em termos dos avanços nos serviços municipais, quanto ao comando das secretarias de saúde por sanitaristas, ainda que fosse exagerado afirmar que se tratava de uma ampla tendência. Mas diferentemente das experiências dos anos 1970, quando a expansão dos serviços de saúde ocorria com base nos recursos municipais, em meados dos anos 1980, mais munícipios enfrentavam o mesmo quadro das oportunidades e dificuldades. De um lado, havia mais governos progressistas e existia a possibilidade de implementar as Ações Integradas de Saúde financiadas pelo governo federal. Todavia, de outro, enfrentavam-se dificuldades como a elaboração de um Plano Diretor necessário para assinar o convênio das AIS e a própria implementação de serviços, que ainda precisava ser "inventada" (Cosem-SP, 2008: 11). Esses elementos se configuravam como ingredientes necessários para o desencadeamento da ação coletiva dos dirigentes municipais de saúde, desde que percebido ou colocado como um problema comum.

As primeiras reuniões dos secretários e dirigentes municipais de saúde no estado de São Paulo, em torno dessas questões, foram incentivadas pelo sanitarista Nelson Rodrigues dos Santos, que, desde os anos 1970, fomentava a vertente municipalista do Movimento Sanitário. Foi como secretário de saúde em Campinas, que ele promoveu as atividades coletivas no nível estadual:

Liguei para os secretários municipais e começamos a nos organizar. Pegamos 17 cidades médias do estado de São Paulo e criamos um colegiado de secretários municipais de saúde. Esse colegiado começou a se reunir frequentemente, e elaboramos um projeto de municipalização. Todas as cidades médias, com seus deputados, prefeitos e a população foram pressionar o governo Montoro para municipalizar (Santos, 2008/2009: 651). 
Flavio Goulart, secretário de saúde de Uberlândia, no estado de Minas Gerais, sanitarista e sócio fundador do Cebes e da Abrasco, foi um dos convidados da primeira reunião de São Paulo e, motivado pela iniciativa, reuniu alguns municípios vizinhos para um encontro semelhante em Minas. O Encontro dos Secretários de Minas Gerais ocorreu em 1984, em Araxá, ao qual se seguiram outros eventos (Goulart, entrevista, 2012).

O processo era incipiente e dependente dos sanitaristas, e os primeiros passos da ação coletiva dos dirigentes e secretários de saúde estavam ainda invisíveis na arena nacional. A participação dos secretários na maior mobilização de saúde da década, a $8^{\text {a }}$ Conferência, em 1986, ofereceu a dimensão da visibilidade. A comissão organizadora do evento, coordenada por Sérgio Arouca, designou para o movimento municipalista doze vagas. No entanto, após a pressão e a insistência que Nelson Rodrigues dos Santos e Flávio Goulart fizeram junto à Comissão Organizadora, as vagas cresceram para mais de 80 (Santos, N. entrevista 2005). As atividades dos secretários e dirigentes municipais não constavam da programação oficial do evento, e sua reunião, fortemente incentivada por Nelson Rodrigues dos Santos (Goulart, entrevista, 2012), foi improvisada nas escadarias do local da Conferência. Lá se discutiu acerca da necessidade de fomentar as associações estaduais, bem como foi esboçada a possibilidade da fundação de uma entidade nacional. Tratava-se de uma ação dos ativistas do movimento, que encontrava solo fértil entre aqueles que vieram à Conferência sem ter, necessariamente, o vínculo com o Movimento Sanitário e sua ação municipalista.

Esse foi o caso de José Eri Osório de Medeiros, dentista cirurgião, dirigente municipal de saúde de Venâncio Aires, do Rio Grande do Sul, que veio motivado pela propaganda sobre a $8^{\text {a }}$ Conferência na televisão, protagonizada por Milton Gonçalves, ator bastante conhecido na época:

\footnotetext{
Ele faz uma divulgação da conferência e diz que vai se reunir lá e que de lá vão sair as propostas para a mudanças de sistema de saúde do país, que iriam combater a miséria, a desigualdade. Eu, Medeiros, dentista, fui motivado por aquela propaganda. Eu não tinha nenhuma ligação, não era delegado. Eu fui lá por causa do Milton (Medeiros, entrevista, 2012).
}

Sua participação na reunião, ocorrida na escadaria do Ginásio de Esportes em Brasília, resultou na fundação da Associação Estadual dos Dirigentes de Saúde 
(Assedisa), no Rio Grande do Sul, apenas dois meses após a Conferência. A transição democrática contaminava as pessoas com a vontade de participar, de fazer parte do curso de mudanças em que se encontrava o país.

Esse também foi o clima dos já citados V Encontro do Setor Municipal de Saúde e IV Encontro dos Secretários Municipais de Saúde, realizados em março de 1987, em Londrina, que reuniram cerca de mil pessoas num clima de intensos debates em torno da Constituinte. Os participantes desses eventos deliberaram a favor da constituição da entidade nacional dos secretários municipais de saúde e elegeram uma Comissão Provisória, composta por 14 membros de 12 estados, encarregada de organizá-la. Entre eles, encontravam-se os seguintes sanitaristas: Aparecida Linhares de Pimenta, Flávio Andrade Goulart, Júlio S. Muller Neto, Ricardo Nogueira, entre outros. A Comissão elaborou um documento intitulado “Proposta para a Criação de um Organismo Nacional de Secretários Municipais de Saúde", submetido à Organização Pan-Americana de Saúde (OPAS) e ao Ministério de Saúde, que o aprovaram. Numa reunião abrigada pela OPAS, em 10 de julho de 1987, na presença do secretário geral do Ministério da Saúde, do representante da OPAS, do secretário nacional de articulação com os estados e municípios, o Conselho Nacional de Secretários Municipais de Saúde (Conasems) foi declarado constituído, como uma associação civil sem fins lucrativos (Goulart, 1996: 45).

A associação dos secretários fazia parte do repertório organizacional da época. Uma fonte inspiradora para os sanitaristas encontrava-se nas Secretarias Estaduais de Saúde, nas quais os secretários estaduais haviam fundado, ainda em 1982, o Conselho Nacional de Secretários de Saúde (Conass). ${ }^{61}$ Nos anos 1970, as Secretarias Estaduais de Saúde eram as mais importantes instâncias públicas responsáveis pela provisão dos serviços de saúde à população não pertencente ao sistema previdenciário. Ao longo dos anos 1976 a 1978, o governo federal repassou os

${ }^{61} \mathrm{O}$ associativismo em torno dos municípios é uma vertente que data dos anos 1940. Atribuída aos dirigentes e técnicos de universidades, institutos de pesquisa (IBGE, DASP, FGV ou INE), a ação municipalista desembocou na constituição de duas organizações nacionais de representação dos municípios: a Associação Brasileira de Municípios de 1946, fundada no processo da redemocratização e da elaboração da Constituinte de 1946, e o IBAM, no formato de associação de sociedade civil, que atuará como o principal órgão divulgador de técnicas modernas de gestão municipal (Melo, 1993). O IBAM aparece como um apoiador dos primeiros encontros municipais de saúde, mas deve ter sido um apoio ocasional, porque não aparece depois e não é confirmado pelos participantes do processo (Goulart, entrevista, 2012). 
recursos a um conjunto de secretarias do Nordeste para a implementação do PIASS, o que fomentou os contatos entre elas (Machado, 2010). No entanto, a tentativa de expansão desse programa de atenção básica para o país inteiro e, consequentemente, dos recursos financeiros, como vimos no capítulo anterior, não foi bem sucedida. Os secretários estaduais ganharam um forte argumento a favor da extensão de sua atuação justamente nessa época. Em 1978, a Assembleia Geral da Organização Mundial da Saúde (OMS), reunida na Conferência de Alma-Ata, terminou suas deliberações com a seguinte recomendação: "Saúde para todos no ano 2000", focando a importância da cobertura universal da saúde primária. Foi essa a bandeira que os secretários assumiram como compromisso do novo coletivo em formação: o de tornar realidade a meta da OMS, conforme publicado no "Documento de Manaus", que coroava sua reunião em dezembro de 1981. A primeira reivindicação dizia respeito à criação de um fundo federal de apoio às secretarias62 (Conass, 2007: 41-43).

Os integrantes da diretoria e da comissão executiva do recém-fundado Conasems buscaram garantir tanto a representatividade externa quanto os espaços da representação intraorganizacional. Em primeiro lugar, foram tomados os passos para oficializar a fundação diante das autoridades públicas: no mesmo dia da reunião na OPAS, o Ministro de Saúde os recebeu, reconhecendo a entidade; no dia seguinte, a diretoria enviou a correspondência às outras autoridades federais e estaduais, comunicando a constituição do Conselho e reivindicando a representação do Conasems no Comissão Interministerial de Planejamento (CIPLAN), órgão responsável pelo planejamento geral e pela programação das ações de saúde entre duas agências responsáveis pelo setor nacionalmente, o Ministério da Saúde e o Ministério da Previdência e Assistência Social. Sua presença no CIPLAN foi confirmada, três meses depois, pela portaria Interministerial número 21, em 22 de outubro de 1987 (Goulart, 1996: 45-46).

\footnotetext{
${ }_{62}$ Outra iniciativa da organização dos secretários de políticas públicas e, mais especificamente, no setor de educação, ocorreu na região metropolitana de Recife, onde a oposição ao regime militar ganhou todas as prefeituras em 1982. O I Encontro Nacional de Dirigentes Metropolitanos de Educação foi realizado em 1985, e, no ano seguinte, foi constituída a União Nacional dos Dirigentes Municipais de Educação (UNDIME). Com o patrocínio do Ministério da Educação, o Fórum Nacional de Dirigentes Municipais de Educação reuniu mais de mil secretários da UNDIME (Neves, 1994: 55). Foi nesta época que também foi constituída a entidade de representação dos secretários estaduais de educação, o Conselho Nacional de Secretários de Educação, o Consed (Neves, 1994: 50).
} 
Os recursos do Ministério da Saúde, de algumas secretarias estaduais de saúde (RS, GO, MS, MG e RJ) e do convênio com o OPAS viabilizaram as atividades do conselho, permitindo-lhe que se projetasse como ator político de relevância (Conasems, 2008: 39). Graças a esses financiamentos, foram promovidas as reuniões regulares da diretoria, não raramente realizadas no Congresso por causa do trâmite da lei que regulamentaria os preceitos constitucionais do novo sistema de saúde, tornando o Conasems o interlocutor quase obrigatório para os representantes do governo e os deputados (Medeiros, entrevista, 2012). A entidade já possuía uma razoável capacidade de convocação, comprovada pelos seus eventos nacionais anuais e pela presença de secretários nas mobilizações da Plenária Nacional de Saúde no Congresso.

A cada dois meses, a partir de fevereiro de 1990 até 1992, o Conasems publicava seu jornal Presença Conasems com tiragem de cem mil exemplares, distribuídos pelas Secretarias Estaduais e Municipais de Saúde, que se tornou uma caixa de ressonância para os principais temas e os desafios da época. Esses também eram vocalizados sistematicamente pela rádio, no programa Bom Dia Brasil, que consistia em entrevistas com o mundo da política e do qual o presidente do Conasems na época, José Medeiros, participou ao menos oito vezes. Nos últimos dias do seu governo, especificamente no dia 08 de fevereiro de 1989, o então Presidente da República, José Sarney, recebeu a diretoria executiva do Conasems, que se propunha coordenar a 9a Conferência Nacional de Saúde. A convocação desse amplo evento foi anunciada, em seguida, sob o tema que não escondia seu protagonista: “Municipalização é o Caminho".

A busca da projeção na arena política do Conasems foi acompanhada pela preocupação dos seus fundadores com a representação interna no sentido formal e organizacional. O Conselho de Representantes, constituído por um representante para cada estado, foi estabelecido desde a fundação, ainda que dela fizessem parte os secretários de apenas doze estados; na época, apenas cinco associações estaduais estavam constituídas ${ }^{63}$. O reconhecimento pelo Ministério teve a contrapartida financeira que resultou na liberação "sem burocracia", nas palavras de um integrante

${ }_{63}$ Essas associaç̃oes foram criadas nos seguintes estados: em Pernambuco, Mato Grosso e Rio Grande do Sul, em 1986; no Pará e Paraná, em 1987 e em Paraíba e São Paulo, em 1988 (Cosems-SP, 2008: 5). 
do Conasems na época, de recursos para as viagens continentais no esforço de montagem da estrutura federativa da organização. As reuniões nos estados eram organizadas normalmente pelo secretário da capital, quem convidava os secretários de outros municípios, entre os quais raramente se encontrava um militante da saúde pública, conforme evidencia o trecho da entrevista de Flávio Goulart, vice-presidente do Conasems na época (1988-1989):

\footnotetext{
O secretário dos primórdios [do início do Conasems], era um médico, aliás raramente não era um médico, e como médico era um cara carregado de interesses. Era dono de hospital, ou sócio do hospital ou amigo dos donos do hospital. O que não impediu que tivesse gente com ideias boas, que queria fazer o sistema público avançar. Mas o nível de contradição era bem maior [do que hoje]. Tinha muitos secretários médicos defendendo os direitos dos médicos (Goulart, entrevista, 2012).
}

O depoimento de Goulart mostra que a organização da ação coletiva dos secretários era uma tática dos sanitaristas de ocupar espaço, espaço esse que seria o de representação política de um tipo de gestor público e que exigia a montagem de uma estrutura federativa. Mais seis associações foram constituídas por meio desse esforço entre os anos de 1989 e 1990: em 1989, no Ceará, Sergipe, Rio Grande do Norte, Alagoas e Goiás e, em 1990, no Espirito Santo (Cosems-SP, 2008: 5), conformando 12 associações. A segunda possibilidade de fomentar as associações estaduais surgiu na preparação da 9a Conferência Nacional de Saúde, entre 1990 e 1992, da qual o Conasems se tornou coordenador, o que exigiu intensas viagens pelo país nas etapas preparatórias: até 1994, vinte e um estados já contavam com as associações de secretários municipais instaladas.

Para o segundo presidente do Conasems, que ficou cinco anos no cargo (19891993), as associações estaduais tiveram, naquela época, um funcionamento mais fraco em comparação à sua filial nacional (Medeiros, entrevista, 2012), o que pode ser explicado pela forma de sua constituição induzida pelos dirigentes nacionais. $\mathrm{O}$ contra exemplo, o de uma associação estadual ativa, como foi o caso da Associação dos Secretários Municipais de São Paulo (ASEMS) “Dr. Sebastião Moraes”, ilumina a dinâmica do funcionamento inicial: o engajamento dos sanitaristas. Entre os quadros dirigentes da ASEMS de São Paulo estavam vários dos militantes do movimento, entre os quais: Aparecida Linhares Pimenta, David Capistrano Filho, Fernando 
Galvanese, Gastão Wagner, Gilson Carvalho, José Ênio Servilha Duarte, entre outros. Fundada em 1988, a Associação “[n]os primeiros anos só existia graças ao trabalho militante de um grupo muito reduzido dos secretários municipais que acreditavam na proposta de municipalização" (Linhares apud Cosems-SP, 2008: 12). Da mesma maneira como ocorria no nível nacional, a associação organizava os encontros estaduais nas cidades em que as secretarias estavam ocupadas pelos militantes, como exemplificam as cidades paulistas: São Bernardo do Campo, Bauru, Santos, Piracicaba e Campinas. Os encontros contavam com centenas de participantes, inclusive com a presença dos secretários e diretores de saúde e constituíam-se como palcos de debate, troca de informações e experiências (Cosems-SP, 2008: 13). Um dos principais temas dos encontros naqueles primeiros anos era a apresentação e a divulgação de informações sobre a municipalização, que para muitos constituía ainda uma "caixa preta", enquanto para os sanitaristas tratava-se de uma realidade em curso havia mais de dez anos.

A municipalização gerava muito polêmica, como expressa o presidente do Cosem-SP:

\footnotetext{
Muitos secretários estavam mais preocupados com a substituição de cargos a tarefas [...] Houve muita polêmica em relação aos sindicatos de médicos, de trabalhadores e associações, porque a municipalização foi afobada, neste aspecto... Os profissionais foram municipalizados sem treinamento, sem unificação de salários e, no começo, foi tudo bastante tumultuado (Gastão, apud Cosems-SP, 2008).
}

Na gestão do sanitarista Gilson Carvalho (1991-1992), as reuniões eram organizadas inclusive por macro regiões para chegar mais próximos aos municípios e secretários:

Tínhamos que mobilizar os secretários municipais de Saúde do Estado para que aderissem ao SUS e para que fossem capazes de assumir seus papéis, na construção do SUS. Aquele foi um momento importante que exigiu muito esforço dos dirigentes [do Cosems-SP]. (Carvalho, apud Cosems-SP, 2008: 24).

Na sua gestão, Gilson Carvalho editava semanalmente o boletim do CosemsSP, denominado SOS Saúde. Esse informativo era encaminhado via fax para os secretários municipais engajados, os quais, por suas vezes, reproduziam-no para os municípios de suas regiões, constituindo uma rede de informações. Eram divulgados 
também os documentos técnicos para politizar os secretários municipais, informações administrativas, de financiamento, gestão e gerência de saúde, contabilidade entre outros.

Em resumo, os militantes do Movimento Sanitário que ocupavam os cargos de dirigentes e secretários de saúde municipais conformaram os embriões de ação coletiva em alguns estados e mantiveram os encontros nacionais. Apoiado pelos programas federais implementados pelos sanitaristas que ocupavam cargos na burocracia nacional, o setor municipal de saúde foi se desenvolvendo, não raramente a partir da grave carência de estrutura. Esse foi o contexto específico no qual os ativistas do movimento criaram uma organização que tornou visíveis os secretários municipais de saúde como atores coletivos, sob a égide dos postulados do Movimento Sanitário no intenso e cambiante período da transição democrática. $\mathrm{O}$ domínio de agência expresso pela forma organizacional - entidade de representação política dos secretários municipais- conduzida pelos sanitaristas, lhes permitirá construir alguns pontos de acesso e influência ao Estado. Acompanharemos esse processo no capítulo quatro.

\section{Síntese}

O período em análise, entre os anos de 1984 e 1989, era de uma conjuntura especial, o de transição democrática, na qual ocorriam fortes mudanças na estrutura de oportunidades políticas. Pela primeira vez em 20 anos, um presidente civil subia ao poder, por meio de uma aliança da qual faziam parte os partidos de oposição ao regime militar. A competição eleitoral nos dois outros níveis federativos, que já havia sido reinstaurada antes, também aumentou o número de Executivos com os partidos progressistas no comando. Com isso, aliados do movimento, potenciais e concretos, chegavam ao poder. A transição se completava com a convocação da Assembleia Constituinte, abrindo uma possibilidade rara de mudanças institucionais. Os atores do movimento lançaram mão de uma série de táticas nesse contexto, seguindo a estratégia do caminho institucional. Utilizaram-se do repertório que incluiu a tática 
de ocupação de cargos, dessa vez mirando os postos mais importantes das agências federais, mas também ocupando-os no nível municipal. Valeram-se do lobby parlamentar na Constituinte, seguindo tanto as formas possibilitadas pelo Regimento Interno da Assembleia Constituinte quanto as não formalizadas, que se constituíam numa prática social compartilhada de pressão junto aos deputados via bases estaduais de mobilização no Congresso. Apropriaram-se do espaço estatal - a Conferência Nacional de Saúde - para promover uma grande mobilização do movimento, ampliar as fileiras de atores comprometidos com sua causa e legitimar seu projeto diante das autoridades públicas e outros atores políticos. Essa terceira tática trouxe um ingrediente não convencional, na medida em que não havia um encaminhamento procedimental estabelecido para tais ocasiões. Tendo nas mãos a materialização da voz da sociedade civil organizada, o Relatório da $8^{\text {a }}$ Conferência Nacional de Saúde, os atores do movimento conseguiram negociar o seu prolongamento, bem como sua atualização pela convocação da Comissão Nacional da Reforma Sanitária. O documento com a proposta para o setor de saúde foi entregue pela Comissão à Assembleia Constituinte, como expressão pactuada entre a sociedade e as instituições públicas setoriais.

Os atores fizeram também o uso não convencional de duas formas organizacionais que lhes permitiram agir politicamente, alargando as fronteiras do movimento. A Plenária Nacional de Saúde, pela sua forma aberta e não institucionalizada, viabilizava com facilidade as mobilizações de acordo com a necessidade do processo da tomada de decisão política na Assembleia Constituinte, ampliando as fileiras dos atores identificados com as causas da Reforma Sanitária. A criação da entidade formal dos secretários municipais de saúde, por sua vez, a qual ofereceu contorno aos anos de mobilização dos militantes do movimento nesse nível da federação, constituiu-se como um domínio de agência, ao se estabelecer como a representação política sob a égide dos postulados do Movimento Sanitário.

O período termina com a promulgação da Constituição, na qual o setor de saúde é aprovado de acordo com os principais termos do prognóstico do movimento que estavam expressos nos seus manifestos, cartas públicas e documentos de alta circulação: como direito do cidadão, como dever do Estado. Além disso, o acesso universal à saúde se instalava por meio de um sistema pautado no comando único, 
descentralizado e com a participação dos usuários na sua gestão, tendo o setor privado como seu fornecedor complementar. Os preceitos constitucionais constituirão uma base legal inédita na qual as ações futuras do movimento pela Reforma Sanitária poderão se apoiar em pleno jogo democrático. 


\section{Guardiões da lei: movimento pela Reforma Sanitária no governo Collor (1990-1992)}

\subsection{Conjuntura: redemocratização, regulamentação da Constituição e instabilidade}

A descrição da conjuntura do governo Collor precisa ser divida em dois blocos: um que diz respeito às pendências deixadas pelo período da transição democrática, e outro que caracteriza o governo do primeiro Presidente civil eleito pelo voto popular, depois do regime militar.

Fernando Collor de Mello, político oriundo de um pequeno partido (Partido da Reconstrução Nacional - PRN), conduziu sua campanha se apresentando como político avesso às coalizações partidárias como forma de compor e conduzir o governo. Na formulação de seu gabinete, de fato ele não recorreu à distribuição dos cargos entre os partidos, abrindo mão da maioria no Congresso.

A vitória eleitoral de Collor devia-se, entre outros, à impopularidade do governo Sarney e do partido que representava, o PMDB (Partido do Movimento Democrático Brasileiro), que ficou fora do novo governo. Logo no início do mandato, a equipe econômica de Collor introduziu um plano econômico que, ao objetivar a redução da hiperinflação, confiscou, inesperadamente, o dinheiro das cadernetas de poupança dos brasileiros. Entre outras formas de sanear e tornar mais competitiva a economia do país, o governo abriu o mercado nacional para os produtos importados, iniciou a privatização de empresas públicas e reduziu o número de servidores públicos. Apesar das medidas, o país entrou em recessão, o desemprego cresceu e a inflação voltou com força. A política econômica e seus resultados não ajudaram a tornar o presidente popular, e sua aprovação foi dramaticamente reduzida com os escândalos de corrupção que conduziram ao seu impeachment, antes do final do mandato, em 1992.

É difícil entender a conjuntura do período em análise, sem levar em consideração as mudanças institucionais em curso. A Constituição, apelidada de “Constituição Cidadã" pelo contraste com a Lei Magna que a antecedia, fora aprovada no final de 1988. Todavia, deixara a tarefa da regulamentação legal de seus 
preceitos como condição indispensável para iniciar os processos de implementação de novas políticas públicas.

No setor de saúde, a Constituição determinava a universalização do acesso à saúde como direito do cidadão e dever do Estado, provida no interior de um novo sistema, denominado de Sistema Único de Saúde (SUS). Sua implementação se daria com base na regulamentação por meio de lei ordinária, cujo trâmite, diferentemente do processo extraordinário da Constituinte, obedeceria aos procedimentos do sistema democrático: a lei teria origem no Poder Executivo, seria aprovada no Congresso e sancionada, por fim, pelo Presidente da República. A tramitação do projeto da Lei Orgânica de Saúde (LOS) colocava os atores do Movimento pela Reforma Sanitária diante do Executivo, do qual eles não faziam parte, e no Congresso significava um confronto com os grupos representantes dos interesses divergentes ao novo sistema, tais como a burocracia estatal do Instituto Nacional de Assistência Médica da Previdência Social (Inamps), e o setor privado de saúde (Weyland, 1995).

Desencadeado em 1991, o início da implementação do SUS era também um momento de mudanças institucionais, pois redesenhava a configuração das instituições e instâncias setoriais. O Ministério da Saúde incorporava o Inamps com sua vasta burocracia, sob o princípio do comando único. As instâncias de deliberação intragovernamental e aquelas que incluíam atores da sociedade civil, construídas nos anos 1980, deixavam de existir. Começavam a ser instalados os Conselhos de Saúde que traduziam o princípio de controle dos Executivos setoriais pela sociedade, em três níveis federativos. Assim, de certa maneira, o clima de transição e instabilidade ainda pairava no ar, apesar das garantias constitucionais.

\subsection{Alteridade em ação}

No período em análise o Movimento pela Reforma Sanitária enquadra o governo federal como inimigo do novo sistema de saúde, e aponta a luta pela sua regulamentação legal e a crítica do Executivo nacional como seus instrumentos de 
ação. Os atores do movimento continuam praticamente os mesmos em relação ao período anterior, e seus eventos ganham um progressivo caráter híbrido, articulando a academia com o setor público de saúde.

4.2.1 Diagnóstico e prognóstico do Movimento pela Reforma Sanitária: inimigos do governo e guardiões da Lei Constitucional

$\mathrm{Na}$ análise do Movimento pela Reforma Sanitária ${ }^{64}$, na passagem dos anos 1980 para os anos 1990, a situação sanitária e a saúde dos brasileiros continuam precárias, e esse elemento do diagnóstico se mantém semelhante ao do período anterior. A diferença consiste na indicação dos responsáveis por essa situação: se antes o legado se devia ao regime autoritário, agora o culpado é o Governo Federal, e esta crítica é feita, tanto em relação ao último ano do governo Sarney - que teria lançado a grande maioria do "nosso povo" na "criminosa miséria" (Carta de Porto Alegre, 1989: 22), quanto ao governo Collor, que provocou a "tragédia sanitária". O modo de governar e a política econômica são fontes dessa situação. O último ano do governo Sarney foi criticado pelo "clientelismo mais rasteiro e pernicioso" e pela "política econômica recessiva ditada fora do País e aplicada subservientemente por Brasília" (Carta de Porto Alegre, 1989: 22). Os atores do movimento se posicionam claramente contra o governo, estando fora dos cargos de direção no Executivo Federal, desde a guinada conversadora do governo Sarney, em 1987.

No primeiro ano de Collor, o governo como um todo não é ainda o alvo das críticas; os atores indicam a política econômica como a fonte dos "resultados desastrosos" para a situação do país, em particular no setor de saúde (Carta de Fortaleza, 1990: 25). Nos eventos de 1992, já no clima de impeachment, a crítica é uníssona e condena o governo pela condução clientelista das políticas sociais, pelo

${ }^{64}$ Como o mandato de Collor foi mais curto em razão do impeachment, adicionamos à análise a posição do Movimento em relação ao último ano do governo Sarney (1989). Ambos os governos guardavam a semelhança entre si no que se refere a não participação do Movimento nos cargos setoriais. 
desrespeito à lei e pela sua "política econômica recessiva e privatizante" (Carta da 9a Conferência, 1992: 15; Carta de Brasília, 1992).

Diante dos governos negligentes em relação às políticas sociais, o prognóstico do movimento consiste, por um lado, na recusa das relações com o governo; e por outro, no empenho pela regulamentação setorial, de acordo com as garantias constitucionais. Ao governo de Sarney, os atores do movimento negam "apoio com todas as nossas forças" e clamam pela presença de todos na "luta institucional que se expressará na votação da Lei Orgânica no Sistema Único de Saúde, da Seguridade Social, das Constituições Estaduais e das Leis Orgânicas Municipais"(Carta de Porto Alegre, 1989: 22).

No primeiro ano do governo Collor, os atores adotam uma postura de vigilantes da Lei Constitucional, zelando para que não haja "retrocesso nos princípios básicos e nas proposições deles derivados" (Carta de Fortaleza, 1990: 25). Todavia, dois anos depois, entendem como "inviável a implementação de qualquer modelo de atenção à saúde dissociada de profundas mudanças na prática política do Governo Federal" (Carta de Brasília, 1992: 26), e reafirmam sua posição como guardiões da Lei, conforme mostra o trecho da Carta de Porto Alegre e de Belo Horizonte, "A Saúde como Direito à Vida", documento aprovado nas Plenárias dos dois Congressos organizados pela Abrasco, em 1992:

\begin{abstract}
A Reforma Sanitária que defendemos impõe o fortalecimento das instituições democráticas que foram arduamente conquistadas nas lutas contra as ditaduras do Cone Sul (...). A Nação brasileira conseguiu promulgar uma Constituição que reconhece a saúde como direito de todos e dever do Estado (...). Essa Constituição tem que ser respeitada e cumprida (Carta de Porto Alegre e de Belo Horizonte 1992: 1).
\end{abstract}

"O momento é grave, mas não deve ser de desesperança" (Carta de Curitiba, 1993: 28), anunciava o Conasems, em julho de 1993, e esse diagnóstico diferenciado foi elaborado já no governo Itamar, quando o movimento voltou a ocupar cargos no Executivo, representado pelo sanitarista do Conasems, Gilson Carvalho, que assumiu a Secretaria do SUS no Ministério da Saúde. Agora, o plano era fortalecer a parceria 
com o Ministério Público, o CONASS e o Ministério da Saúde, na defesa da Reforma Sanitária brasileira (Carta de Curitiba, 1993: 29).

\subsubsection{Eventos e atores do Movimento pela Reforma Sanitária65}

Os eventos regulares organizados pelos atores do movimento no período em análise confirmam seu caráter de encontros híbridos. Isto é, perde-se definitivamente a linha divisória entre os eventos de caráter acadêmico e aqueles relacionados com o setor de saúde. São organizados em torno de temáticas específicas, e não do papel particular desempenhado por um ou outro tipo de participante no sistema (seja ele pesquisador, estudante, profissional de saúde, etc.). Reúnem públicos diversos que se identificam com o tema em pauta e manifestam seu posicionamento político por meio de documentos aprovados no coletivo. A Conferência Nacional de Saúde, evento organizado pelo Ministério da Saúde, afirma-se como evento sob a condução do Movimento. O período "herda" os atores já presentes na transição democrática, que saem dela fortalecidos e com capacidade de mobilização e barganha.

A presença das críticas diretas ao governo federal no diagnóstico é uma expressão do fato de que os sanitaristas não ocupavam os principais cargos de direção no setor. Outra evidência dessa posição de outsiders é a não realização da Conferência Nacional de Saúde na data prevista (em 1990) - um evento do setor público de saúde que havia sido apropriado pelo Movimento Sanitário em 1986 e transformado em espaço de deliberação e legitimação de sua proposta política, com base na ampla participação da sociedade civil organizada. Sua convocação pelo Ministro da Saúde sofreu um atraso de dois anos em relação à regra de ocorrência a cada quatro anos, devido à resistência do governo Collor ao evento ${ }^{66}$ e apesar da

\footnotetext{
${ }^{65}$ A fim de manter a comparação com outros períodos analisados, e tendo em vista que o governo Collor durou três anos incompletos, incluímos na análise de eventos, dois anos a mais que correspondem ao governo Itamar Franco que, como vice do Presidente deposto, assumiu o mandato depois do impeachment. Todavia, ressaltaremos na análise as características dos eventos do governo Collor.

${ }^{66} \mathrm{Na}$ última edição de 1986, a Conferência Nacional de Saúde havia reunido quatro mil pessoas, dentre as quais, várias lideranças da sociedade civil organizada, adquirindo claramente um caráter de
} 
pressão dos atores do movimento, tais como a Plenária Nacional de Saúde e o Conasems, e da insistência do Conselho Nacional de Saúde. (Brasil/MS/SEGEP, 2006).

A 9a Conferência foi realizada em agosto de 1992, na esteira de grandes mobilizações nacionais contra o Presidente da República, a favor de sua deposição. Um dos dias da Conferência foi chamado de "Dia do Grito", e os participantes se deslocaram para o Congresso, a fim de se manifestarem contra Collor. Sintomaticamente, afirmando o protagonismo do movimento como organizador das Conferências Nacionais, todas as outras Conferências ${ }^{67}$ temáticas ocorreram quando um sanitarista ocupou um importante cargo no Ministério da Saúde, já no governo assumido pelo Vice do Presidente deposto, Itamar Franco. Dentre outros eventos de caráter setorial, os Encontros dos Secretários Municipais de Saúde se estabilizaram, sendo realizados regularmente, uma vez por ano.

Os eventos conjunturais, convocados ad hoc para discutir a conjuntura e articular as ações, escassearam, se comparados ao período anterior. Esta ausência não significava, necessariamente, que os atores do Movimento pela Reforma Sanitária não estavam conectados, interpretando os acontecimentos. Como já havia ocorrido ao longo da Assembleia Constituinte, a Plenária Nacional de Saúde estava operando e mantendo as entidades do movimento articuladas por meio das suas reuniões executivas e das próprias reuniões da Plenária (Brasil/MS/SEGEP, 2006), acompanhando o processo de elaboração da Lei Orgânica da Saúde e outros desdobramentos políticos importantes.

O Conasems, além dos regulares encontros anuais, realizava também suas reuniões mensais nas dependências do Congresso, o que permitia aos seus integrantes acompanhar o processo, exercer pressão e estar em comunicação direta, ainda que informal, com os Parlamentares e representantes do governo (Medeiros, entrevista, 2012).

mobilização. Na visão do governo, isto poderia constituir um potencial explosivo de mobilização social na capital do país, risco inexistente na convocação do novo Conselho Nacional de Saúde, que ocorreu, este sim, no início do segundo ano do governo Collor.

${ }^{67}$ Em comparação a primeira onda das conferências organizadas pelo movimento em meados dos 1980, não foram realizadas a Conferência de Consumidor e a da Saúde da Mulher, e foi convocada uma nova, a Conferência Nacional de Ciência, Tecnologia e Inovação. 
Os dois eventos conjunturais - a Reunião da Lei Orgânica de Saúde e o Seminário do Projeto Montes Claros ao Sistema Único de Saúde: Os Desafios da Revisão Constitucional - corresponderam às oportunidades e ameaças percebidas pelos atores que se reuniram para elaborar, respectivamente, o texto da lei que contornaria os vetos de Collor à LOS, em novembro de 1990, e quando o Sistema Único de Saúde (SUS) foi alvo de uma contra investida do setor privado, na Revisão Constitucional de outubro de 1993.

Entre os eventos regulares do movimento, fica clara a tendência da organização de encontros que incorporam a academia, o setor de saúde e a comunidade, calcados no pressuposto de que a produção acadêmica e a formação devem estar voltadas às necessidades do novo sistema, numa clara expressão da estratégia de formação do campo profissional. Estão entre eles, fora a Congresso da Abrasco, estão também os Congressos da Rede IDA e três novos eventos: o Encontro Brasileiro de Ciências Sociais em Saúde e o Congresso Brasileiro de Epidemiologia, ambos promovidos pela Abrasco; e o Encontro Nacional da Economia da Saúde da Abres.

Esses eventos também proporcionam um espaço de encontro de diferentes organizações e grupos do Movimento pela Reforma Sanitária, e de reconstrução constante da definição compartilhada do projeto do Movimento. Por exemplo, o principal evento da Associação Brasileira de Pós-Graduação de Saúde Coletiva, o Congresso Brasileiro de Saúde Coletiva, não limitava a inscrição dos trabalhos àqueles strictu senso acadêmicos, nem à participação dos pesquisadores. O objetivo era propiciar uma maior participação dos profissionais dos serviços e da comunidade, por meio da sistematização de seus trabalhos; e também, reunir os atores envolvidos com a Reforma Sanitária para debater os temas conjunturais e compartilhar as experiências ${ }^{68}$ (Belisário, 2002: 236). Esse Congresso também se

\footnotetext{
${ }^{68} \mathrm{O}$ Boletim da Abrasco discrimina os participantes entre "representantes de Universidades e Centros de Pesquisa; de Organizações Não Governamentais de Saúde; do Legislativo Municipal, Estadual e Federal; do Judiciário; do Ministério Público; de organizações sindicais; conselhos profissionais; comunidades e associações populares; Secretarias Municipais e Estaduais; membros dos Conselhos Municipais, Estaduais e Nacional de Saúde; profissionais de Saúde; professores e pesquisadores da área da Saúde Coletiva; Prefeitos e Governadores; representantes do Conasems e Conass, respectivamente; prestadores privados de serviços; além da expressiva participação do usuário do Sistema Único de Saúde" (Abrasco, 1994: 8).
} 
constituiu como plataforma para a realização de reuniões e encontros, tanto os regulares, quanto os inéditos, ligados aos atores do Movimento pela Reforma Sanitária (Belisário, 2002: 233). Por exemplo, na sua quarta edição, em 1994, que reuniu 3.800 participantes em Olinda, houve a realização da Assembleia do Cebes; a reunião conjunta do Conass e do Conasems; a 1a Reunião Nacional de Conselheiros de Saúde; o Encontro Nacional de Representantes de Saúde do Legislativo; e a reunião das ONGS em Saúde. Aproveitou-se sua organização, na véspera das eleições presidenciais, para encaminhar a Carta de Pernambuco sobre a Saúde no Brasil, aprovada em Assembleia Geral, aos candidatos à Presidência da República (Belisário, 2002: 238-239).

Os atores do Movimento pela Reforma Sanitária no governo Collor continuam os mesmos do período da transição, a saber: a Abrasco, o Cebes e o Conasems que, juntos, atuavam por meio da Plenária Nacional de Saúde, à qual se agregava um grande número de entidades, tais como: os Conselhos Federais de Medicina, Farmácia, Psicologia e Odontologia; a Confederação Nacional dos Trabalhadores; as Federações Nacionais de Enfermeiros, Médicos e Odontologistas; a Federação Nacional dos Sindicatos dos Trabalhadores em Saúde, Trabalho, Previdência e Assistência Social; o Sindicato Nacional dos Docentes das Instituições de Ensino Superior; a Confederação dos Trabalhadores da Agricultura; a Confederação Nacional de Associação de Moradores; e o Movimento Popular de Saúde. ${ }^{69}$

O Conasems, como já adiantamos no terceiro capítulo, monta sua estrutura de associações nos estados justamente durante a elaboração da LOS e ao acompanhar as pré-Conferências em municípios e estados, rumo à realização da 9a Conferência, da qual era coordenador.

Entre novos atores com projeção nacional está a Rede de Projetos de Integração Docente-Assistencial/Brasil ou, simplesmente, a Rede IDA, que se propunha a buscar "interferir nas políticas públicas de recursos humanos de Saúde, principalmente na formação dos recursos humanos de nível de graduação, para aprimorar a difícil articulação dos serviços de saúde com as

\footnotetext{
${ }^{69}$ Essas entidades compunham a Coordenação da Plenária Nacional de Saúde (Relatório da Reunião
} da Plenária Nacional de Saúde, 1992) 
universidades." (http://www.redeunida.org.br/rede-unida/nossa-historia, acessado em 20 de julho de 2012).

A Rede IDA foi instalada em agosto de 1985, durante a I Reunião de Coordenadores de Projetos IDA, em Belo Horizonte. Esses projetos, desenvolvidos por departamentos de universidades articulados com os serviços públicos e as comunidades, desde os anos 1970, iam na contramão da formação voltada a profissionais liberais, que os preparava para atuarem no mercado. Uma parte dos projetos foi financiada pela Fundação Kellogg, e outros eram vinculados ao "Cooperação Técnica OPAS-Brasil em Recursos Humanos", um programa interministerial com a chancela da OPAS, que permitia a alguns militantes do movimento desenvolverem atividades de formação e ensino voltadas para os objetivos da Reforma Sanitária.

Em meados dos anos 198070, apesar de pontuais em relação à tendência geral dos cursos superiores em saúde, os projetos IDA não constituíam um conjunto de experiências ligadas única e exclusivamente ao financiador em comum - a Fundação norteamericana, W. K. Kellogg. Conduzidos pelos professores e gestores que se identificavam com o Movimento pela Reforma Sanitária, os projetos buscavam formas de conexão e disseminação de sua visão da formação.

Os primeiros encontros da Rede IDA foram fomentados pela própria Fundação Kellogg, em parceria com a Capes, como forma de tentar constituir um embasamento metodológico e substantivo, comum aos projetos. Já o II Encontro de Coordenadores da Rede IDA de 1987 não se restringiu aos participantes dos projetos. Foram convidados a participar aqueles que tinham alguma inserção institucional ou liderança em outros projetos, alinhados com a formação para a Reforma Sanitária (Barbieri, 2006: 54; Pires-Alves, Paiva, 2006: 105). A partir de então, o evento começou a adquirir claramente um caráter político de discussão e articulação de ações

\footnotetext{
70 Ainda no início dos anos 1980, houve uma tentativa de ampliar os IDA para o Brasil inteiro, no chamado Programa de Integração Docente-Assistencial (PIDA), que partiu da Secretaria de Educação Superior (SESU) do MEC - na época dirigida por Frederico Simões Barbosa, um grande adepto da ideia de integração entre ensino e serviços -, em parceria com os integrantes da "Cooperação". O projeto, que consistia em criar dez macro regiões docente-assistenciais no Brasil, não saiu do papel (Santana, entrevista 2005; Pires-Alves; Paiva, 2006 83-87). O PIDA enfrentou a resistência bem sucedida da Associação Brasileira de Educação Médica (ABEM), com base no argumento de que os projetos IDA colocavam em xeque a autonomia universitária (Pires-Alves, Paiva, 2008: 86).
} 
(Barbieri, 2006: 48-49). A estratégia da formação para a realização da Reforma Sanitária era o mote de debate nos eventos, frisando-se a necessidade da busca por uma formação "que atendesse às necessidades, tanto dos acadêmicos, no que se refere ao ensino contextualizado, quanto das comunidades com atendimento direcionado para suas necessidades." (Boletim Informativo Rede IDA/Brasil, n4, 1987 apud Barbieri, 2006: 53).

Em 1992, a Rede IDA teve uma participação mais substantiva na 9a Conferência Nacional de Saúde, ao preparar o documento “Contribuição das Universidades Públicas do Rio de Janeiro aos Debates da IX Conferência de Saúde", publicado pela Revista do Cebes e distribuído na Conferência (Barbieri, 2006: 58).

Surgem nessa época, os Núcleos de Saúde Coletiva em diversas universidades, desempenhando um papel de formadores, consultores e apoiadores das Secretarias Estaduais e Municipais de Saúde, que começam em massa a implementar os serviços de saúde. A Associação Brasileira de Economia da Saúde (Abres) foi criada em 1989 com a proposta de utilizar as ferramentas dessa nova disciplina acadêmica para auxiliar a gestão dos serviços públicos de saúde.

\subsection{Estratégias em prática}

No capítulo anterior, acompanhamos como o Movimento pela Reforma Sanitária ocupou importantes cargos no governo, ao mesmo tempo em que atuou durante a Constituinte, desenvolvendo a tática de lobby pautada em constantes mobilizações. Nos dois planos, os atores defendiam o projeto do movimento. A aprovação do novo sistema de saúde, de acordo com os princípios da Reforma Sanitária, coloca o movimento em uma outra posição - desta vez como guardião da Lei Constitucional. Assim, no início da redemocratização do país, o movimento conta com essa sólida base legal, mas no nível Federal, sua estratégia de caminho institucional como norte de suas ações fica de certa maneira suspensa: o movimento se encontra fora do governo e ainda não existe a regulamentação necessária para começar a implementação do SUS. Nesse contexto, ocorre o veto do Poder Executivo 
que coloca em xeque os princípios básicos do sistema de Saúde. As táticas e atividades dos atores do Movimento na situação na qual seu projeto foi gravemente ameaçado compõem o conteúdo do processo, descrito a seguir.

O período em análise, apesar de um novo governo civil eleito com base no voto democrático, é marcado ainda pela transição no que se refere às mudanças institucionais no setor de Saúde: algumas agências e instituições deixam de existir, enquanto outras surgem. Entre os arquitetos desse novo sistema está o movimento, que participa do seu desenho. Essa configuração única se mostra interessante para investigar de que maneira os atores buscam construir seus pontos de acesso e influência no Estado, de modo a impedir que as contingências ditem as regras da sua interação com o Governo Federal. O retrato desse momento será captado pelo episódio do qual o Conasems é o protagonista.

O capítulo também retoma as ações ligadas à outra estratégia da formação do campo profissional. Embora praticamente invisível no diagnóstico aqui retratado, no qual os atores privilegiam a urgência da construção legal do novo sistema, a questão da formação aparece nos eventos. Chama a atenção a regularidade dos eventos da Rede IDA, que articula uma diversidade de atores em torno da formação dos quadros para o sistema público de Saúde. Outros eventos do movimento indicam também a crescente integração entre os serviços públicos de saúde e a academia. Além disso, com a preeminência da implementação do novo sistema, a questão deixa de ser marginal e coloca diante do movimento o desafio de formar dezenas de milhares de profissionais.

A que táticas os atores recorrem quando se trata de uma área de atuação sob o domínio de agência de um outro setor de políticas públicas? Os episódios selecionados buscam retratar os atores do movimento nessas situações.

\subsubsection{Estratégia de formação do campo profissional}

Em 1980, o setor público de saúde contava com 265.956 profissionais. Em 1992, esse número dobrou, ficando o setor com 537.688 funcionários e, em 2005, duplicou 
novamente, totalizando 1.069.440 de profissionais ${ }^{71}$ (Instituto Brasileiro de Geografia e Estatística - IBGE). Esse dado não é usado aqui como indicador ou parâmetro da qualidade, mas sim para dimensionar o crescimento do contingente de "recursos humanos", como se convencionava chamar os profissionais de saúde nos anos 1980 no setor público de saúde. Tal crescimento, que traduz a implementação dos serviços públicos de saúde, a ampliação de sua cobertura e a sua diversificação, também coloca a problemática da formação dos profissionais da qual se poderia encarregar o sistema educacional - via escolas técnicas e universidades públicas, ou via setor privado -, não fosse a clareza dos sanitaristas de que a formação desses profissionais, fator crítico do novo sistema de saúde, precisava se dar no espírito da Reforma Sanitária. Como, aliás, havia sido a formação dos primeiros militantes do movimento nos Departamentos de Medicina Preventiva, nos projetos de medicina comunitária, nos cursos de saúde pública e nos mestrados em medicina social (Pires-Alves; Paiva, 2006). Se esses eram cursos voltados a profissionais com alto grau de escolaridade, nos anos 1980 e 1990, colocam-se também como necessidades a formação de atendentes de baixa qualificação e de profissionais técnicos, a capacitação dos gestores do novo sistema de saúde em fase da implementação, ampliando o leque de linhas de atuação cujas prioridades nem sempre eram consensuais entre os militantes do movimento.

No segundo capítulo, vimos como os sanitaristas aproveitaram as oportunidades abertas com os investimentos do governo Geisel (1974-1979) em ciência e tecnologia para desenvolver atividades de formação e pesquisa alinhadas com a nova visão de saúde. Um dos caminhos institucionais aproveitados foi o PPREPS, Programa Interministerial de Preparação de Recursos Humanos para o setor de saúde, desenvolvido no interior do "Acordo Técnico de Cooperação" com a Organização Pan-Americana de Saúde (OPAS). Nos governos seguintes, marcados pela crise econômica, as oportunidades exógenas não se repuseram, no entanto, alguns sanitaristas continuaram ocupando cargos no "Acordo" o qual, sendo interministerial e sob o manto da organização internacional, lhes deixava uma relativa autonomia para o desenvolvimento de algumas ações e projetos alinhados

${ }^{71}$ IBGE, Pesquisa Assistência Médico-Sanitária (vários anos). Exclui os empregos administrativos. 
com a Reforma Sanitária, como a residência em saúde coletiva, projetos de Integração Docente-Assistencial entre outros.

A partir de 1983, com a mudança na forma de contratação (seus membros perderam salários pagos em dólar pela OPAS) e a instabilidade de recursos decorrente da crise econômica, a decisão de permanecer no "Acordo" tornava-se uma decisão pessoal, mas pautada pelas possibilidades que ele oferecia para fazer avançar o projeto da Reforma Sanitária: "Se não houvesse um engajamento político do grupo com esse programa, ele teria desaparecido", avaliava um dos sanitaristas integrantes do "Acordo": "Eu posso dizer isso sem nenhum proselitismo, foi a minha opção, a da Isabel [dos Santos], a do Roberto Nogueira e a Francisco Lopes de permanecer nesse grupo"72 (Santana, entrevista, 2005: 25).

Eram todos funcionários públicos, concursados em várias instituições, que insistiram em continuar no "Acordo", porque ele oferecia condições de desenvolver ações cujo perfil não só desafiava o status quo no setor de saúde - foi a equipe do “Acordo" que elaborou, em 1979, o projeto do Prev-Saúde, que propunha a universalização do acesso à saúde no país - mas também permitia colocar em prática algo pouco comum na época, a saber, a formação voltada para suprir as necessidades do setor público de saúde. Os sanitaristas não encontravam nos padrões de formação existentes oferecidos pelo sistema educacional, tanto no nível técnico quanto no universitário, nos sistemas privado ou público, propostas capazes de viabilizar a preparação de recursos humanos. Alinhada ao mercado ou voltada para as finalidades da pesquisa universitária, a oferta e conteúdo curricular de cursos estavam distantes do que precisariam as secretarias municipais de saúde, em termos de formação de seus quadros; dos usuários das periferias das grandes cidades, os quais necessitavam de médicos generalistas; e, ainda, dos atendentes de saúde sem qualificação que, em dezenas de milhares, faziam as vezes dos profissionais mais qualificados no Brasil afora. (Santana, entrevista, 2005; Santos, 2007; Nunes, entrevista, 2005).

$\mathrm{O}$ “Acordo" era um espaço institucional no qual a formação podia se dar sob a ótica da Reforma Sanitária, e entre as atividades desenvolvidas podem-se citar o

72 Trabalhou no "Acordo" também, ainda que por menos tempo, sanitarista Alberto Pellegrini Filho. 
Projeto Larga Escala, que visava formar profissionais de nível médio e elementar; os projetos de Integração Docente-Assistencial (IDA), que buscavam adequar os currículos dos cursos superiores de saúde às necessidades dos serviços públicos de saúde; e as residências de Medicina Preventiva e Social abertas a profissionais externos à área de saúde, que preparavam quadros para o sistema público de saúde (Pires-Alves; Paiva, 2006: 72). Ainda que essas experiências não tenham constituído programas nacionais, guiaram e subsidiaram a reflexão, o debate e o posicionamento dos atores do Movimento pela Reforma Sanitária em relação à formação de profissionais de saúde. Uma série de evidências disso encontra-se nos três marcos, a Conferência Nacional de Recursos Humanos de 1986, a Constituição de 1988 e a Lei Orgânica da Saúde (LOS) de 1990.

A $1^{\text {a }}$ Conferência de Recursos Humanos73, sob o tema A Politica de Recursos Humanos Rumo à Reforma Sanitária, em 1986, foi realizada na esteira da histórica 8a Conferência Nacional de Saúde, e sua coordenação estava composta pela equipe do “Acordo" - Izabel dos Santos, José Francisco Paranaguá de Santana, Roberto Passos Nogueira - além de sanitaristas, como Paulo Marchiori Buss e Tânia Celeste Matos Nunes, entre outros. O relatório final da Conferência expressava a visão do movimento sobre a formação (Relatório da $1^{\text {a }}$ Conferência Nacional de Recursos Humanos para a Saúde, 1986: 9):

\begin{abstract}
A necessidade de uma articulação mais estreita entre as instituições que prestam serviços e aquelas que formam pessoal de saúde foi um ponto de unanimidade. Parece imperioso que a área de Desenvolvimento de Recursos Humanos para a saúde conquiste condições políticas e técnicas que viabilizem a premissa de que saúde é um direito do cidadão e um dever do Estado
\end{abstract}

Essas condições, continuava o Relatório, "serão inalcançáveis sem que haja um entendimento entre as áreas de ensino e de prestação de serviços" (Relatório da $1^{\text {a }}$ Conferência Nacional de Recursos, 1986: 9). Com essa proposição, os atores

\footnotetext{
${ }_{73} \mathrm{O}$ termo "recursos humanos", muito atrelado à área de administração, pode ofuscar o leque de temas da Conferência que abrangeu tanto os temas ligados à situação do trabalhador (e não a gestão dos trabalhadores como "recursos humanos") e suas condições de trabalho quanto a temática de formação dos profissionais para atuarem no sistema público de saúde.
} 
deixavam claro que havia obstáculos a essa cooperação. Sugeria-se, então, a "articulação interinstitucional para a criação de uma política nacional de recursos humanos com vistas à reforma sanitária" e ressaltava-se a importância de que "o setor saúde oriente[asse] os conteúdos curriculares a serem implementados pelo sistema educacional" (Relatório da 1a Conferência Nacional de Recursos, 1986: 23).

As deliberações da Conferência foram incorporadas à proposta da Comissão Nacional de Reforma Sanitária entregue à Constituinte, na qual declarava-se que "o ensino e a pesquisa essenciais para a saúde" seriam "subordinadas à política nacional de saúde" (Rodrigues Neto, 2003: 200). Na Constituição a "subordinação" não foi alcançada, todavia, no artigo 200, inciso III, um ponto de acesso e influência foi conquistado: estava entre as competências do Sistema Único de Saúde - SUS "ordenar a formação de recursos humanos na área de saúde". O verbo "ordenar" era pouco utilizado na linguagem jurídica (Romero, 2008), dando margem a várias interpretações e possibilidades. Os militantes do movimento pela Reforma Sanitária tentaram precisar essa formulação na redação da LOS e conseguiram aprovar no Congresso o artigo 29 mediante o qual se determinava que "as escolas públicas que formam recursos humanos para a saúde serão subordinadas ao Sistema Único de Saúde - SUS, salvo as de ensino universitário" (Brasil. Lei No 8.080 de 19 de setembro 1990). A LOS foi encaminhada para a sanção do Presidente da República, que a vetou em vários artigos, entre os quais, o vigésimo nono, alegando que a duplicidade de controle sobre essas escolas "dá causa a conflitos e perplexidades quanto à atividade fiscalizadora e normalizadora da autoridade administrativa" (Brasil. Mensagem de veto, No 68 de 20 de setembro de 1990: 6). A duplicidade seria talvez o resultado da interpretação da lei pelos atores, porque, como veremos a seguir, o que os militantes queriam claramente era o domínio do setor de saúde sobre a formação dos profissionais de níveis médio e elementar.

A questão da formação de recursos humanos ficou definida na Lei Orgânica como atribuição de uma "comissão intersetorial" subordinada ao Conselho Nacional de Saúde (CNS), composta por integrantes dos Ministérios e entidades representativas da sociedade civil com capacidade de "articular políticas e programas de interesse para a saúde, cuja execução envolva áreas não compreendidas no âmbito do SUS" (Brasil. Lei No 8.080 de 19 de setembro 1990, art. 
12). Seriam convocadas também, determinava a LOS, as "Comissões Permanentes de Integração entre os serviços de saúde e as instituições de ensino profissional e superior" (Lei No 8.080 de 19 de setembro 1990, art. 14) às quais caberia "propor prioridades, métodos e estratégias para a formação e educação continuada dos recursos humanos do Sistema Único de Saúde (SUS)" (Brasil. Lei No 8.080 de 19 de setembro 1990, art. 14).

A instalação das comissões intersetoriais implicava futuras negociações em torno da formação, restringindo a influência do setor de saúde a esses caminhos institucionais. Todavia, as necessidades da Reforma Sanitária, na visão e ação de seus militantes, não podiam esperar. O que os episódios narrados a seguir - o Projeto Larga Escala, a criação dos Núcleos de Saúde Coletiva e a avaliação da necessidade social dos cursos superiores em saúde - têm em comum são as tentativas dos ativistas do movimento de subordinar a formação às necessidades do sistema público de saúde e, com isso, se defrontar com o domínio de agência do Ministério da Educação e seus atores. A diretriz constitucional de "ordenar a formação de recursos humanos na saúde", como competência do SUS, figurou como ponto de influência nessa área, todavia, mostrou-se insuficiente para embasar ações de grande abrangência. O primeiro episódio mostra a elaboração dos cursos pilotos para a qualificação dos atendentes de saúde nos interstícios do sistema educacional e a tentativa frustrada de ampliá-los para o nível nacional. O segundo episódio foca a implementação dos Núcleos de Saúde Coletiva também nos interstícios educacionais por meio dos quais foi possível direcionar as ações das universidades para as necessidades de curto e médio prazos dos serviços de saúde. O terceiro episódio conta o uso do preceito constitucional de ordenação como base legal para influenciar o processo de autorização dos cursos superiores na área de saúde,- o que confirma, no entanto, seu caráter limitado. 
4.3.1.2 O Projeto Larga Escala: formação para a Reforma Sanitária nos interstícios dos setores de políticas públicas

Parece óbvio para quem está dentro do sistema, mas está longe da primeira impressão de quem é dele usuário, que a provisão de serviços de saúde também depende dos profissionais de nível elementar. Esses, dependendo da região do país onde há falta de profissionais mais qualificados, podem desempenhar funções acima de suas qualificações formais. Quando Izabel dos Santos, enfermeira, negra e militante do Partido o Comunista Brasileiro, criou o Projeto Larga Escala no interior do "Acordo", em 1980, o contingente de atendentes sem qualificação chegava a 150 mil, número equivalente ao de médicos (Santos, 2007: 845). A proposta de formação de profissionais de saúde de níveis médio e elementar foi construída na chave de dupla crítica que se referia às experiências de formação vivenciadas até então no "Acordo" e àquelas fomentadas pelos próprios sanitaristas na Escola Nacional de Saúde Pública. Izabel dos Santos tecia críticas à forma mecânica de capacitar milhares de auxiliares na primeira fase do PPREPS, por um lado e, por outro, rejeitava a ênfase na formação de quadros superiores. Como o disse Rita Sório, coordenadora do programa que expandiu de fato a formação de profissionais nos anos 2000:

Nós estamos falando de expansão da cobertura da saúde no Brasil, nós estamos falando que vamos fazer atenção primária de saúde, nós estamos falando que vamos mudar o foco individual para o coletivo, e como eu vou formar um contingente de trabalhadores que não são os filhos da elite médico, odontólogo -, que estão completamente apartados dessa discussão? (Observatório, 2006: 59).

O aluno que o Projeto Larga Escala visava atender era exatamente um "apartado", isto é, um atendente que trabalhava nas comunidades pobres, de nenhuma ou pouca escolarização, espalhado por todo o Brasil e, a partir de 1985, ameaçado de ser demitido por não possuir qualificação em conformidade com as regras estabelecidas pela Conselho Nacional de Enfermagem ${ }^{74}$. O perfil do aluno e as críticas de Izabel dos Santos deram origem a um projeto em bases metodológicas

${ }^{74} \mathrm{O}$ Conselho Federal de Enfermagem deu prazo de 10 anos para a qualificação profissional dos atendentes sob a ameaça de não poderem mais exercer a profissão. Quem não fosse qualificado, não seria registrado no Conselho Regional e perderia o direito de exercer legalmente a função de atendente. 
distintas, concebidas pela sua coordenadora a partir da combinação de uma série de metodologias (entre as quais, as de Paulo Freire, de Jean Piaget, de Joffre Dumazedier e de Paul Legrand, fundadores do Movimento Povo e Cultura, da França, entre outros ${ }^{75}$ ) numa proposta original, a qual, na síntese da própria idealizadora, consistia no "processo de aprendizagem, um ensino-aprendizagem em cima do processo real de trabalho do aluno" (Santos, 2007: 856).

Izabel dos Santos insistia na ideia de tornar o setor público de saúde o centro de formação, e não apenas o receptor dos profissionais da área. Considerava que a formação dos técnicos em saúde não deveria se dar nas escolas ligadas ao Ministério da Educação (MEC); antes, precisaria ser atrelada às secretarias estaduais e municipais de saúde, de modo a ser mais facilmente ajustada às necessidades dos trabalhadores da área, tanto em termos dos currículos quanto na estruturação dos cursos, de modo a evitar que fossem afastados das suas atividades profissionais (Pires-Alves; Paiva, 2006: 198). Para tanto, seriam estabelecidas escolas exclusivamente profissionalizantes, ligadas às secretarias estaduais e municipais de saúde, voltadas para os trabalhadores empregados, apresentando como corpo docente os próprios profissionais do serviço público (Observatório, 2006: 61).

O desenho do projeto não obedecia à estruturação dos cursos profissionalizantes reconhecidos pelo MEC, de modo que Izabel dos Santos precisou procurar algum modelo existente no qual pudesse enxertar legalmente suas escolas de saúde e, com isso, garantir o reconhecimento do MEC mediante a certificação dos cursos. O único modelo do MEC que se aproximava do que o Larga Escala se propunha a fazer era o sistema de ensino supletivo, e como tal foi apresentado aos Conselhos Estaduais de Educação a quem competia a aprovação dos cursos e, por conseguinte, a chancela dos certificados (Bassinello; Bagnato, 2009: 623).

O desenho do Projeto Larga Escala passou, assim, ao largo das escolas do MEC, fomentando a constituição dos Centros de Formação de Recursos Humanos

\footnotetext{
75 "A metodologia alternativa consubstanciada pelo Larga Escala compreendia um processo pautado na compreensão da realidade. Buscava desenvolver um programa educativo vinculado a uma prática concreta, numa interação entre sujeito e objeto no ambiente de trabalho, a partir da observação dos problemas, identificação de seus determinantes e análise de soluções alternativas. Visava à aprendizagem no serviço, especialmente para trabalhadores sem qualificação ou formação específica" (Bassinello; Bagnato, 2009: 623).
} 
(CEFOR) e das Escolas Técnicas nas secretarias estaduais e municipais (Observatório, 2006: 42-43). O projeto foi implementado em quatro estados, sejam esses, Piauí, Rio Grande do Norte, Alagoas e Minas Gerais, apoiado, em parte, no financiamento federal oriundo do "Acordo" e em seis escolas de auxiliares de enfermagem do Instituto Nacional de Assistência Médica da Previdência Social (Inamps), nos estados do Rio de Janeiro, São Paulo, Bahia, Pernambuco, Maranhão, Goiás, com graus muito diferenciados de sucesso (Pires-Alves; Paiva, 2006: 80; Bassinello; Bagnato, 2009: 621). Era um trabalho, como diz a própria idealizadora, nas "brechas da lei". O Larga Escala se inseria nos interstícios dos setores de políticas públicas: atribuindo ao setor de saúde a tarefa de formar os seus quadros para o qual a formação de recursos humanos era novidade, com a chancela do MEC pela mera e formal semelhança com o sistema supletivo.

Os atores do movimento aprovaram a experiência do Larga Escala como uma das propostas legitimadas pelo coletivo da Conferência Nacional de Recursos Humanos que indicava que "o perfil dos profissionais de nível médio e elementar deverá atender às necessidades do setor saúde adequando-se à reorganização dos serviços com vistas à Reforma Sanitária, destacando-se o auxiliar de enfermagem" e apontavam como uma das soluções a criação de "Escolas Técnicas Públicas, de caráter multiprofissional e específicas para o setor saúde" (Relatório da $1^{\text {a }}$ Conferência Nacional de Recursos Humanos para a Saúde, 1986: 24). Mas a tentativa de inscrever na LOS a subordinação dessas escolas ao SUS, como vimos anteriormente, foi vetada e, portanto, não incorporada na segunda parte da LOS, especificamente, a 8.142, de 1990.

Uma oportunidade para expandir o Larga Escala se abriu quando Carlos Sant'anna, um político aliado do Movimento pela Reforma Sanitária, assumiu a pasta da Educação no governo federal, em 1989. A equipe do "Acordo" preparou um projeto que buscava no MEC o financiamento das Escolas Técnicas de Saúde e garantiria, automaticamente, o reconhecimento dos cursos. O resultado do processo indica que também essa tentativa, apesar do poderoso aliado e do preceito constitucional já em vigor, não foi bem sucedida. A necessidade da formação técnica, como uma ideia, não foi questionada, mas o espaço institucional e o controle sobre essa formação, pois o MEC, em decorrência da proposta, criou a área de saúde em 
suas escolas técnicas federais e escolas agrotécnicas (Santana, entrevista, 2005: 31). Este desfecho estava distante do objetivo não convencional que o Larga Escala queria introduzir, como o próprio nome o enuncia, em grandes extensões: a formação dos trabalhadores de níveis elementar e médio sob a coordenação do setor de saúde.

O problema do reconhecimento pelo MEC, da certificação legal e da ampliação do Larga Escala serão superados no contexto da crise instaurada pelo fim do prazo que o Conselho Federal de Enfermagem estipulara para a qualificação técnica dos atendentes de saúde conjugada com a decisão política do Ministro de Saúde, José Serra, no final dos anos 1990. O projeto foi rebatizado para Projeto de Profissionalização dos Trabalhadores da Área de Enfermagem (Profae) e implementado a partir do ano 2000, sob o comando das sanitaristas. Em cinco anos, 13.161 enfermeiros docentes em formação profissional técnica foram engajados no programa, formando 241 mil auxiliares e 70 mil técnicos. O Ministério da Saúde (MS) constituiu, a partir do Profae, 319 escolas técnicas de saúde, públicas e privadas (Trabalho e Formação em Saúde - A Trajetória de Izabel dos Santos, 2010). O setor de saúde começava a compartilhar o domínio de agência sobre os cursos técnicos, antes da exclusividade do MEC.

\subsubsection{Os Núcleos de Saúde Coletiva: nas margens das universidades}

A implementação dos espaços nas universidades voltados para as necessidades da Reforma Sanitária - os Núcleos de Saúde Coletiva - foi iniciada com a ida de Paranaguá de Santana para o INAMPS (Instituto Nacional de Assistência Médica da Previdência Social), em 1985, a convite do militante do movimento Hésio Cordeiro (Castro, 2008: 93), que ocupava o cargo de presidência da autarquia, como vimos no capítulo 3. Santana, que "estava simplesmente ocupando um espaço que era mais poderoso para influenciar um processo", deixava temporariamente o "Acordo" para ocupar o cargo dirigente do recém-constituído Departamento de Recursos Humanos (Santana, entrevista, 2005). Santana era um médico, sanitarista que optou por não fazer nenhum dos cursos de especialização em Saúde Pública, 
mas, mesmo assim, sua trajetória sempre foi atrelada aos grupos e entidades do Movimento Sanitário. Vivenciou o projeto de Planaltina, umas das experiências de saúde comunitária dos anos 1970 desenvolvidas por vários departamentos de medicina preventiva, bem como foi um dos fundadores do núcleo do Centro Brasileiro de Estudos de Saúde (Cebes) em Brasília. A partir de 1979, entrou no Ministério de Educação, na Secretaria de Ensino Superior, por indicação de alguns de seus professores, e foi indicado para fazer parte do grupo do "Acordo", fazendo dessa atuação o seu projeto político (Santana, entrevista, 2005).

A forma organizacional dos Núcleos de Saúde Coletiva fazia parte do repertório organizacional existente na época. Santana havia conhecido o modelo de núcleos interdisciplinares da Unicamp, implementado pelo reitor José Aristodemo Pinotti (Santana, entrevista, 2005: 29). Os Núcleos eram híbridos: faziam parte das universidades, aproveitavam o corpo docente, mas seu formato lhes desobrigava das atividades de docência e pesquisa stricto senso ditadas tanto pelas normas universitárias quanto pelas do MEC. O fato de pertencer à universidade conferia a eles o estatuto de instituição pública, o que facilitava a circulação dos recursos públicos, os quais, no caso dos Núcleos de Saúde Coletiva, provinham do Inamps, das Secretarias Estaduais de Saúde, dos SUDS (Sistemas Unificados e Descentralizados de Saúde) e da OPAS com o objetivo de financiar as atividades ligadas às demandas de serviços públicos.

A adoção da forma de núcleo decorria, na visão de Santana, da dificuldade de convencer as universidades a atuarem a serviço do setor público de saúde. O sanitarista ressalta esse embate no seguinte depoimento:

Eu cheguei a me reunir com o pró-reitor de graduação em várias universidades, pra aprovar o curso de especialização em gerência de unidades básicas (GERUS), ou o CADRHU [Capacitação em Desenvolvimento de Recursos Humanos de Saúde], e pra esclarecer uma coisa que deveria ser do conhecimento deles e que eles não sabiam. Todo mundo achava que a universidade só pode dar curso de especialização, obedecendo uma portaria do Conselho Federal de Educação. Eu digo, "você já leu essa portaria, como é?". Essa portaria diz: 'regulamenta o curso de especialização para a função docente'. Eu não quero curso de especialização para a função docente. Então, a universidade tem autonomia de aprovar um curso de especialização, do jeito que ela negociar com o serviço de saúde. Ela não precisa obedecer essa resolução. Ah, mas nós temos de obedecer as normas do MEC. Eu digo, "mas o MEC não define norma". "Ah, então vocês 
têm que conversar com o MEC, ou com o Conselho Federal de Educação pra...", eu digo: "não, eu não, ó, quem tem que fazer isso são vocês". [Era assim] em muitas universidades. (Santana, entrevista, 2005: 29).

O propósito dos Núcleos de Saúde Coletiva consistia em articular as necessidades dos novos serviços públicos de saúde, instalados por meio das Ações Integradas de Saúde (AIS) e, em seguida, mediante os SUDS, com as competências das universidades. Uma evidência dessa vinculação é que a criação de um Núcleo e o seu financiamento precisavam ser aprovados pelas comissões intergestoras do SUDS 76 em cada estado, e não por um convênio entre uma agência federal financiadora e a Universidade (Santana, entrevista, 2005). A composição das equipes não deveria ser apenas de especialistas das universidades, mas de "pessoas das instituições envolvidas na reforma sanitária" (Santana, entrevistas, 2005: 29). Entre 1986 e 1989, foram criados o Núcleo de Estudos em Saúde Pública (NESP), ligado à Universidade de Brasília (UnB); o Núcleo de Estudos em Saúde Coletiva e Nutrição (NESCON), ligado à Universidade de Federal de Minas Gerais; o Núcleo de Estudos em Saúde Coletiva (NESCO), ligado às Universidades Estaduais Paranaenses de Londrina, Maringá e Ponta Grossa e outros nos estados da Paraíba, Rio Grande do Norte, Ceará, Pernambuco, Goiás, Santa Catarina, Mato Grosso (Cordoni Jr.; Martins, 1989: 59).

As atividades dos Núcleos de Saúde Coletiva abrangiam as demandas do processo político. Por exemplo, o primeiro a ser instalado, o Núcleo de Estudos em Saúde Pública (NESP) da UnB, era coordenado por Eleutério Rodrigues Neto, que, junto com José Gomes Temporão e uma equipe de sanitaristas, construiu as propostas de redação para o capítulo de saúde da Constituição (Temporão, entrevista, 2005: 76; Nitão, 2003: 91). Outros núcleos se engajaram, entre os anos de 1989 e 1990, na elaboração dos textos sobre saúde das constituições estaduais, das leis ordinárias estaduais e das leis orgânicas municipais. (Cordoni Jr.; Martins, 1989: 58).

As necessidades de municipalização dos serviços demandavam dos Núcleos as atividades de ensino, assessoria e consultoria, entre os quais podemos citar, a título de ilustração, os cursos de curta duração sobre a política de medicamentos e

${ }^{76}$ As AIS e os SUDS foram programas que antecederem o SUS, introduzidos pelos sanitaristas que ocupavam os cargos no Inamps, conforme vimos nos capítulos anteriores. 
sobre o controle de natalidade, a produção de artigos para a imprensa não especializada sobre a Reforma Sanitária, a organização de simpósios sobre saúde do trabalhador para os sindicatos, entre outros (Cordoni Jr.; Martins, 1989: 58). No estado de Mato Grosso, por exemplo, a partir da iniciativa do Conselho dos Secretários Municipais de Saúde (Cosems-MT) junto com o Núcleo de Desenvolvimento de Saúde (NDS) da Universidade Federal do Mato Grosso (UFMT), foi criado, em julho de 1990, um grupo de trabalho para assessorar os secretários municipais de saúde na criação e na organização de serviços de saúde praticamente inexistentes no estado. O convênio, cuja coordenação coube a dois propositores, ao Cosems-MT e ao NDS, foi celebrado entre a Secretaria Estadual de Saúde e a UFMT. O projeto, de duração de três anos, previa oficinas de 40 horas de duração realizadas em Pólos Regionais e, na etapa seguinte, a assessoria específica a municípios interessados (Pereira et al., 1991: 94).

O trabalho dos Núcleos era também coordenado pelo nível federal, como ocorreu num projeto de abrangência nacional, o Curso de Aperfeiçoamento em Desenvolvimento de Recursos Humanos (1987-1991), mediante o qual foi promovida a capacitação dos dirigentes de secretarias estaduais de modo a sintonizá-los com os princípios e as propostas da Reforma Sanitária. O projeto capacitou, via Núcleos, 730 egressos, advindos dos 24 estados e Distrito Federal (Pires-Alves; Paiva, 2006: 108).

As atividades de alcance nacional dependiam da ocupação de cargos pelos sanitaristas (Weyland, 1995: 1708). O Programa de Desenvolvimento Gerencial do Departamento de Recursos Humanos do Inamps, dirigido por Santana, previa instalar, em cada estado, doze áreas temáticas que eram prioritárias para a implantação tanto dos processos de descentralização quanto da implementação do Sistema Único de Saúde, com o apoio dos Núcleos. Todavia, o programa foi abortado quando se iniciou o governo Collor. Indicado para o cargo pelo Presidente, o novo assessor de recursos humanos do Ministério da Saúde, ao qual estava então submetido o Departamento de Recursos Humanos do Inamps ${ }^{77}$, avaliou como

\footnotetext{
77 Antes de ser extinto, em julho de 1993, o Inamps, com o início da vigência do Sistema Único de Saúde, foi incorporado pelo Ministério da Saúde, e os ocupantes dos cargos de direção do Ministério acumulavam os equivalentes no Inamps.
} 
desnecessário esse programa (Santana, 2005: 30). Santana já havia voltado ao "Acordo" naquele período.

4.3.1.4 Ordenar não é controlar: credenciamento dos cursos de saúde do nível superior

Em 1989, Fabiola Aguiar Nunes, sanitarista, foi trabalhar a convite de um secretário do Ministério de Educação, na área de administração de hospitais universitários. Guiando-se pelo lema de “onde quer que eu esteja, eu estarei ajudando a Reforma Sanitária" e, claramente, pela tática de ocupação de cargos, Nunes decidiu dedicar-se ao fortalecimento dos cursos de formação dos futuros profissionais do SUS (Nunes, entrevista, 2005). Debruçou-se sobre o processo de credenciamento de cursos de ensino superior com a lente de quem conhecia a desigualdade regional, em termos de distribuição das escolas médicas, bem como das distorções decorrentes da disponibilidade de profissionais para trabalhar no sistema público de saúde. Descobriu que a primeira das três etapas do credenciamento consistia na avaliação da necessidade social do curso; a seguinte, na qualidade do projeto pedagógico; e a última, na capacidade financeira da instituição educacional, todas até então apreciadas e julgadas pelo Conselho Nacional de Educação (e, antes de 1988, pelo Conselho Federal de Educação). Fabiola Aguiar Nunes olhava o processo pelo prisma do preceito constitucional incrustrado na seção dedicada ao setor de saúde, no qual o inciso III do artigo 200 atribuía ao setor de saúde o ordenamento de formação de recursos humanos na área de saúde.

Foi justamente na base desse preceito que a sanitarista propôs transferir a avaliação da necessidade social dos cursos para o Conselho Nacional de Saúde. Argumentava que o uso dos recursos humanos era feito pelo setor fim - o de saúde e esse teria, portanto, melhores condições de avaliar a necessidade de se construir uma universidade ou instalar um curso em uma dada região. A proposta fez eclodir uma guerra dentro do MEC, segundo a sanitarista (Nunes, entrevista, 2005), mas a mudança foi feita e dezenas de processos relativos à autorização de universidades e cursos na área de saúde seguiram às mãos dos conselheiros nacionais de saúde. 
Com essa transferência, a influência sobre o processo de credenciamento que estava sob domínio exclusivo de um setor público passava, em parte, a outro e, nele, a um conjunto de atores ligados à Reforma Sanitária. A influência era parcial, porque, embora avaliado como desnecessário do ponto de vista social, o curso ainda poderia ser autorizado pelo Conselho Nacional de Educação, uma vez que pertenciam a ele tanto as duas etapas subsequentes quanto a decisão final. Um caso paradigmático, presenciado por Nunes, foi o da Universidade Luterana do Brasil (ULBRA), no Rio Grande do Sul, que entrou com processo para abrir a faculdade de medicina onde já existiam sete escolas, das quais quatro federais, e onde abundava a oferta de profissionais. O Conselho Nacional de Saúde julgou que não haveria necessidade de mais um curso, mas o Conselho de Educação autorizou a sua abertura. Depois, a partir de 1996, mais de uma centena de faculdades de medicina foi aberta sem seguir o critério de necessidade social (Jatene, 2011: 81). O preceito constitucional que atribuía ao setor de saúde a competência de ordenar a formação permitiu criar uma base legal - mas apenas um ponto de influência - para poder interferir no processo que estava sob domínio de agência do outro setor de políticas públicas e dos atores e interesses a ele ligados.

\subsubsection{Estratégia do caminho institucional}

4.3.2.1 O processo da aprovação da Lei Orgânica de Saúde no governo Collor: táticas "fora das instituições"

O trâmite da Lei Orgânica de Saúde (LOS), regulamentadora dos preceitos constitucionais do novo sistema de saúde no Brasil, colocou o movimento pela Reforma Sanitária novamente no Congresso. O poder executivo teve um prazo de seis meses, a partir da promulgação da Constituinte, para mandar ao Congresso o projeto da LOS. No entanto, não o fez, pressionado por diversos grupos com interesses privados (Weyland, 1995). Um mês após o prazo estipulado, o movimento organizou seu VI Simpósio sobre a Política Nacional de Saúde, em maio de 1989, que encheu os corredores do Congresso com centenas de pessoas, mostrando a força 
numérica do movimento (Santos apud Brasil/MS/SEGEP, 2006: 132). O relatório do Simpósio continha os artigos da LOS, que haviam sido elaborados pelo Núcleo de Estudos de Saúde Pública da Universidade de Brasília, dirigido por Eleutério Rodrigues Neto (Barros, entrevista, 2009).

O papel de mobilizador foi assumido novamente pela Plenária Nacional de Saúde, a qual reproduzia as táticas utilizadas na Assembleia Constituinte. Seus integrantes acompanharam o processo da tramitação do projeto da lei dentro do Congresso até a sua aprovação, promovendo as reuniões de caráter mobilizatório no Congresso (Medeiros, entrevista, 2012) e recorrendo à prática das reuniões com as lideranças e pressão junto aos parlamentares (Carvalho, entrevista, 2012). Eduardo Jorge, sanitarista que se elegeu deputado federal pelo voto do movimento popular de saúde que ele próprio ajudou a organizar nos anos 1970, lança uma explicação do funcionamento da pressão da "base eleitoral" junto aos deputados em comparação à tática dos protestos:

Os deputados que eram contra eram 'buscados', para que a Plenária
pudesse, ao mesmo tempo, adicionar um elemento de pressão efetiva, para o
deputado saber que na base dele tinha gente articulada, gente preparada,
gente com a argumentação capaz de criticá-lo. O deputado não tem medo de
manifestação genérica, se a base de lá de Pernambuco, do Paraíba, do
Amapá, não é muito afetada. Ele é imune, resistente à pressão desse tipo,
salvo a movimentos muito grandes com o Diretas Já, o impeachment, que
vira uma coisa em que ninguém está a salvo da pressão. (...) Mas, quando o
deputado federal, por exemplo, lá do Ceará, recebia a visita do deputado
estadual, do vereador, dos secretários municipais do interior do Ceará, ele
prestava atenção na coisa, porque sabia que isso tinha repercussão na sua
cidade, na sua base. Então esse elemento qualitativo do movimento foi
importante porque serviu para diminuir as resistências, amenizar a oposição
que a gente tinha no setor. (Jorge Sobrinho apud BRASIL/MS/SEGEP, 2005:
135, grifos nossos)

Outros atores do setor também estavam exercendo pressão sobre o Congresso. O setor privado fazia o lobby, e a burocracia do Inamps, refratária ao processo da descentralização que colocava em xeque a sua atuação, elaborou o seu próprio projeto de lei, impedindo a descentralização (Weyland, 1995: 1708). Cada artigo foi objeto de disputa acirrada e exigia a atenção e a presença contínua da Plenária 
Nacional de Saúde no Congresso ${ }^{78}$ (Silveira Neto, entrevista, 2005). A Lei 80.80, correspondente ao projeto do movimento, foi aprovada pelo Congresso, mas, submetida à aprovação do Presidente Collor, sofreu uma série de vetos. A que repertório recorreram os atores quando a contestação veio do cargo mais alto do Executivo?

Dos vetos do Presidente Fernando Collor à Lei Orgânica da Saúde, dois são os mais lembrados: o veto às Conferências Nacionais e aos Conselhos e o veto à transferência direta, regular e automática dos recursos aos estados e munícipios sem a necessidade de celebrar convênios. Nas palavras de um dos militantes do movimento, com os vetos, "a LOS nascia descabeçada", na medida em que se retiravam dela duas das três diretrizes constitucionais, quais sejam, a participação da comunidade e a descentralização ${ }^{79}$ (Brasil, 1988, art. 198), guias do projeto do Movimento pela Reforma Sanitária. Fernando Collor tornava evidente a sua posição política em relação à participação da sociedade civil organizada nas políticas públicas, ao impedir a constituição das instâncias participativas. Ao anular as transferências diretas, centralizava o poder no nível federal, mantendo o controle sobre os recursos. Todavia, os vetos de Collor não significavam a impossibilidade do diálogo com o poder Executivo. As negociações foram conduzidas por intermediação do Ministro da Saúde, Alceni Guerra.

Os ativistas das duas entidades com presença em Brasília na época, a Plenária Nacional de Saúde e o Conselho Nacional de Secretarias Municipais de Saúde (Conasems), relatam as reuniões com Alceni Guerra, médico e funcionário do Inamps sem vínculos com o movimento. A Plenária conseguiu, por exemplo, uma audiência com o Ministro, na qual explicitava sua capacidade de mobilizar e articular cujo resultado era o consenso obtido no Congresso em torno da LOS, e solicitava ao Ministro o comprometimento de não alterar nada que estava dentro da lei no momento da aprovação pelo Presidente (Drummond, entrevista apud Brasil/MS/SEGEP, 2006: 132). Apesar da promessa, o então presidente do Conasems,

\footnotetext{
${ }_{78}$ Em alguns estados como, por exemplo, Mato Grosso, Distrito Federal e Rio Grande do Sul, o formato organizacional da Plenária como articulação das entidades foi reproduzido para articular os atores em torno da pressão nos legislativos estaduais no período da aprovação das constituições estaduais.

${ }^{79} \mathrm{O}$ terceiro, embora não nessa ordem, era o "atendimento integral, com prioridade para as atividades preventivas, sem prejuízo dos serviços assistenciais" (Brasil, 1988, art.198).
} 
Eri Medeiros, lembra que o Ministro convocou uma reunião com os atores do movimento pela Reforma Sanitária, informando-lhes acerca dos vetos do Presidente, antes que a notícia se tornasse pública.

Os atores se colocaram em posição de uma possível mobilização. O Conasems reuniu suas associações estaduais, as quais decidiram lançar uma mobilização para derrubar os vetos, anunciada no bimensal jornal do Conasems, o Presença Conasems, editado em 100 mil exemplares, publicado em setembro de 1990. No editorial, o repertório de ação estava posto: “Na crise, mobilização e negociação". Os secretários ligados à causa da Reforma Sanitária deslocavam-se para Brasília, faziam reuniões internas com vistas à articulação, pressionavam o Ministério da Saúde e as lideranças parlamentares. Eram muitos, representavam uma diversidade de munícipios e, entre esses, também os de grande porte, o que lhes garantia força política. Eram pluripartidários, o que lhes permitia, com efeito, acionar uma diversidade de partidos. Independentemente do partido e do tamanho dos municípios, os secretários ligados ao Conasems estavam mobilizados: “A gente chegava a passar quinze dias em Brasília. Meu município que era mais rico me dava a diária e no meu quatro de hotel dormiam quatro ou cinco secretários que vinham dos municípios sem recursos" (Carvalho, entrevista, 2012).

O Congresso estava pronto para derrubar os vetos do Presidente, mas o canal de negociação estabelecido com o Ministro da Saúde deu origem a outra solução, que evitou a derrota de Collor no Congresso - ponto defendido por seu ministro nas negociações com os atores do movimento. A solução passou pela elaboração de uma nova lei que contemplasse dois princípios indispensáveis ao movimento e vetados por Collor. Sua confecção ficaria por conta dos atores do movimento, que receberiam, para tanto, um recurso mediante o convênio que o Ministério firmou com o Conasems. Esse encontro aconteceu no feriado do dia 15 de novembro de 1990, reunindo os principais atores organizacionais, como o Conasems, o Cebes, a Abrasco (Associação Brasileira de Pós-Graduação de Saúde Coletiva), a Plenária e vários ativistas do movimento (Brasil/MS/SEGEP, 2006: 134). O projeto de lei seguiu ao Ministério da Saúde.

No início de dezembro de 1990, Alceni Guerra mandou um emissário de Brasília a Fortaleza, onde estavam reunidos os participantes do VI Encontro Nacional 
dos Secretários de Saúde, realizado em Fortaleza, no período de 9 a 12 de dezembro de 1990. O emissário do Planalto entregava ao coletivo a cópia do ofício assinado pelo presidente Collor, por meio do qual ele encaminhava ao Congresso a proposta da lei elaborada pelo movimento no feriado da República (Carvalho, entrevista, 2012; Medeiros, entrevista, 2012). A negociação no Congresso foi rápida. A Lei Orgânica de Saúde número 8.142, que revertia os dois vetos do Presidente Collor à LOS 80.80, foi aprovada pelo Congresso em 28 de dezembro de 1990, sem a votação no Plenário, por acordo entre as lideranças partidárias.

Um canal aberto de relações e negociações com o ministro, isto é, com o cargo mais alto do executivo setorial, não garantia o controle sobre o Ministério. Mal os militantes conseguiram voltar para casa para comemorar as festividades do final do ano, o novo sistema estava sendo posto em xeque novamente pela Norma Operacional Básica (NOB), que entraria em vigor a partir do 1 de janeiro de 1991, regulamentando o SUS. Ignorando a LOS, seu autor, o Inamps, ainda em operação naquela época, tornava os municípios os prestadores de serviços do nível federal, à imagem e à semelhança do que fizera durante muitos anos com o setor privado. Os municípios que atendiam à população receberiam, pela NOB 01/1991, do governo federal os valores referentes aos procedimentos ligados à assistência médica. A norma foi interpretada pelos sanitaristas como antítese do SUS e da LOS, mediante a qual se pretendia a descentralização com autonomia, bem como a atuação dos secretários com responsabilidade no planejamento, na organização, na coordenação e na execução das ações (Carvalho, entrevista, 2012). O movimento entrou com uma ação judicial contra essa NOB e contra o Ministério de Saúde, no qual o Inamps encontrava-se na condição de autarquia.

Em suma, no período da aprovação da LOS, o Movimento Sanitário não ocupava os cargos dirigentes nas agências setoriais, o que aponta o limite da tática de ocupação de cargos e a sua vinculação com a politica partidária. Os atores dedicaram-se às táticas "fora das instituições" como o lobby e as negociações com o Ministro de Saúde. Valeram-se da tática de criação de textos das leis que precisavam ser votadas, de modo a completar o processo da regulamentação do SUS de acordo com a Constituição. 
4.3.2.2 Escapando das contingências: o Conasems e os seus pontos de acesso e influência ao Estado

No cambiante contexto das instituições no setor de saúde com a instalação do novo Sistema Único de Saúde (SUS), caducavam alguns espaços de negociação, enquanto outros eram instituídos. A instância de negociação intragovernamental, constituída ainda nas Ações Integradas de Saúde e perpetuada no SUDS (como a Comissão Interministerial de Planejamento - CIPLAN, da qual o Conasems fazia parte), tornava-se parte do passado, enquanto o Conselho Nacional de Saúde, antes meramente consultivo, ganhava o caráter deliberativo e uma composição mais heterogênea e diversificada em relação ao seu antecedente. Era um momento no qual os pontos de influência no Estado estavam mudando de modo que os atores organizados podiam interferir nesse processo. Aproveitando o momento de mudanças no desenho institucional, os sanitaristas criaram dois pontos que viabilizavam potencialmente a interferência do Conasems no processo de tomada de decisão no nível federal: um na nova instância participativa (Conselho Nacional de Saúde) e outro no processo intragovernamental de decisão.

O Conasems, junto com o Conselho Nacional de Secretários Estaduais de Saúde - Conass (presidido entre os anos de 1989 e 1990 pelo sanitarista e municipalista Nelson Rodrigues dos Santos), obteve êxito na aprovação de um artigo na LOS, o qual estabelecia a representação nominal de suas entidades na composição do Conselho Nacional de Saúde. Depois dos vetos do Presidente, o projeto de lei que repunha dois dos artigos vetados, elaborado, como vimos, pelo movimento, recolocava também a representação das duas entidades no Conselho, do qual fariam parte também, discriminados genericamente, representantes do governo, prestadores de serviço, profissionais de saúde e usuários. Na esteira das negociações com o mais alto executivo setorial, embora a realização da 9a Conferência Nacional de Saúde fosse constantemente adiada, a convocação do Conselho foi possível, e sua primeira reunião ocorreu três meses depois da aprovação da LOS, em abril de 1991. Ainda que precisasse da homologação pelo Ministro da Saúde para tornar as 
decisões efetivas, o novo Conselho possuía o poder de deliberação. A partir dessa atribuição e da posição assumida pelo Conasems no Conselho, o segundo ponto de influência no Estado foi construído pelos secretários-sanitaristas.

Na primeira reunião do Conselho Nacional de Saúde, o então presidente do Conasems apresentou um ponto de pauta: a discussão sobre a criação de uma comissão intragovernamental que colocasse juntos os três níveis federativos para debater e tomar decisões relativas à gestão descentralizada do SUS. A primeira reação dos participantes, lembra Medeiros, era compor esse órgão com a participação de todos, posição da qual recuaram, depois da argumentação de Medeiros a favor da exclusividade do espaço para os representantes dos governos do sistema federativo, atentando para o fato de que as suas decisões seriam submetidas ao Conselho. A proposta levada pelo presidente do Conasems havia sido elaborada por iniciativa dos sanitaristas Nelson Rodrigues dos Santos e Gilson Carvalho, com a ajuda de dois engajados juristas, Guido Carvalho e Lenir Santos. A recomendação do CNS legitimaria o espaço que visava a institucionalizar a influência do Conasems e do Conass no processo decisório que ocorria no nível federal. Apesar do lobby parlamentar e do acesso ao mais alto executivo setorial no governo Collor de que os secretários sanitaristas dispunham, o contato com o MS era considerado incerto e insuficiente. O trecho abaixo, do presidente do Conasems na época, elucida a incerteza advinda das relações pautadas nas contingências:

\footnotetext{
Nas reuniões mensais realizadas na Câmara dos Deputados, (Comissão de Saúde e Seguridade Social), ou na sala de reuniões do Ministro de Saúde, com o Conass, apesar da disponibilidade e da vontade política de todos os avanços nas decisões e nos encaminhamentos, o administrativo estava lento, quando não descontectado das estruturas e secretarias do Ministério da Saúde; surgiu, portanto a necessidade de oficializar a interlocução entre os gestores, e principalmente na operacionalização dos avanços da descentralização e da municipalização preconizados pela nossa entidade (Medeiros apud Conasems, 2008: 40).
}

O CNS em sua Resolução No. 2 de 26/4/91 recomendava ao Ministro da Saúde a criação de:

uma Comissão Especial visando discutir e elaborar propostas para a implantação e operacionalização do SUS constituída pelas três instâncias gestoras públicas, União pelo Ministério da Saúde, Secretarias Estaduais de 
Saúde pelo Conselho Nacional de Secretários Estaduais de Saúde (CONASS) e Secretarias Municipais de Saúde pelo Conselho Nacional de Secretários Municipais de Saúde com a incumbência de desenvolver esta relação entre as três esferas de governo, com o compromisso que esta Comissão apresente seus resultados ao CNS.

A Resolução do CNS seria homologada pelo Ministro da Saúde, em julho de 1991, pela portaria 1180, mas a Comissão ficou inativa até o momento em que o representante do Conasems, o sanitarista Gilson Carvalho, assumiu o cargo de Secretário do SUS, no Ministério da Saúde, já no governo de Itamar Franco (19921994). Seu desenho, denominação e função serão definidos pela NOB 1993, um instrumento legislativo do Ministério de Saúde. A comissão foi batizada de Comissão Intergestores Tripartite (CIT) e teve os seus equivalentes estaduais, as Comissões Intergestores Bipartite (CIB), e todas elas constituirão, junto com o CNS, "foros de negociação e deliberação" do gerenciamento do processo de descentralização do SUS80 (NOB, 1993). A capacidade de influência no processo da descentralização por meio desse ponto de acesso ao processo decisório, como o era a CIT, variará de acordo com o ocupante do Ministério da Saúde e não poderia prevenir a centralização do poder decisório pelo Ministério durante o governo de FHC (Arretche, 2005).

$\mathrm{Na}$ leitura dos atores, as comissões precisavam de mais respaldo legal para serem respeitadas pelos Executivos Estaduais e Nacional e precisavam ser inscritas na lei (e não depender legalmente apenas de uma portaria ministerial que podia, a qualquer momento, ser revogada). Em 25 de agosto de 2011, a Lei Orgânica de Saúde, a histórica lei 80.80, sofria dois acréscimos no seu artigo 14, que tiravam a contingência do Conasems. O primeiro acréscimo reconhecia a CIT e a CIB como foros de negociação e pactuação entre gestores quanto aos aspectos operacionais do Sistema Único de Saúde (art. 14 A), bem como admitia o Conasems como entidade representativa dos entes municipais em matérias referentes à saúde e declarava-o de utilidade pública e de relevante função social, na forma de regulamento (14-B), garantindo os recursos do Fundo Nacional de Saúde para o custeio das suas despesas e autorizando a celebração dos convênios. Os Cosems foram reconhecidos como

${ }^{80}$ Sua relevância nos estados dependerá dos Conselhos Estaduais de Secretários Municipais de Saúde e de a sua pressão junto às Secretarias Nacionais de Saúde para convocá-las e, no nível federal, do perfil do Ministro de Saúde (Arretche, 2005). 
entes representantes dos municípios, desde que vinculados institucionalmente ao Conasems.

\section{Síntese}

No processo de elaboração e aprovação da regulamentação, com a qual se iniciará a implementação do Sistema Único de Saúde, o movimento fez uso da tática de lobby parlamentar conjugada com a de negociação com o Executivo setorial. O lobby, uma tática do tipo convencional, realizada "fora das instituições", incluía as negociações com as lideranças partidárias, a pressão sobre os Deputados pelas suas bases estaduais e as mobilizações no Congresso.

O conflito com o Presidente da República, instaurado pelos vetos presidenciais a dois princípios básicos da Reforma Sanitária - a descentralização e a participação -, fez pairar no ar a possibilidade de um protesto nacional anunciado pelo Conasems, mas o movimento não precisou recorrer a essa tática. A Plenária Nacional de Saúde e o Conasems lançaram mão da tática convencional pertencente às ações "fora das instituições": a negociação com o Ministro da Saúde. E o fizeram na posição de atores já considerados relevantes no setor, com importantes posições institucionais e capacidade de mobilização - da Plenária faziam parte várias Federações e Confederações de Sindicatos e os Movimentos Populares de Saúde, e o Conasems representava o poder de mobilização e a influência de centenas de Secretários Municipais de Saúde. Nesse período o movimento empregou ainda a tática "via instituições" que consistia na elaboração do texto da Lei Orgânica de Saúde.

A construção do arcabouço institucional para o novo sistema de saúde se revelou uma oportunidade para arquitetar dois pontos de acesso e influência no Estado. Embora estivesse fora do governo, o movimento tirava proveito das instituições que seus atores construíram como parte do poder Executivo Federal. O Conasems garantiu sua presença nominal no novo Conselho Nacional de Saúde e, 
como seu membro, conseguiu aprovar a resolução que recomendava ao Ministro da Saúde a criação de um espaço intragovernamental de negociação entre os representantes governamentais dos três níveis da Federação. A Comissão Intergestores Tripartite (CIT) garantiria certa influência dos sanitaristas no processo decisório, junto ao Ministério da Saúde, relacionado com a descentralização do SUS.

A implementação dos serviços públicos de saúde, que já se iniciara com os programas introduzidos pelos sanitaristas na década de 1980, tornava a estratégia de formação do campo profissional mais preeminente. Os episódios aqui relatados, relacionados com essa estratégia, mostram a adoção da tática de ocupação de cargos que pertence à categoria de ações "via instituições" já do tipo convencional, mas o conteúdo - a subordinação da formação dos profissionais ao setor de Saúde - traz um elemento não convencional. Com essa demanda, o movimento desafiava o domínio de agência do Ministério de Educação, que se expressava pela competência exclusiva da autorização e certificação dos cursos superiores e técnicos, como também pela definição dos conteúdos curriculares. Os militantes agiam também nos interstícios dos setores de políticas públicas. O episódio do projeto "Larga Escala" é uma ilustração dessas experiências "nas brechas da lei", como o é a implementação dos Núcleos de Saúde Coletiva, constituídos nas margens institucionais das universidades.

O movimento buscou legitimar a formação coordenada pelo setor de saúde por meio da Conferência Nacional de Recursos Humanos para a Saúde, em 1986; e na Constituição, conseguiu construir um ponto de acesso e influência nessa área, atribuindo como competência do SUS o "ordenamento da formação de recursos humanos". O preceito podia embasar legalmente a ação dos ativistas, mas como foi ilustrado pelo episódio de transferência da avaliação da necessidade social dos cursos superiores para o Conselho Nacional de Saúde, era limitado para enfrentar o domínio do MEC e de seus atores.

A formação dos profissionais alinhada com as necessidades da Reforma Sanitária terá de esperar por novas oportunidades, como veremos nos capítulos cinco e seis. 


\section{Movimento pela Reforma Sanitária no governo FHC (1995-1998)}

\subsection{Conjuntura: estabilidade monetária, ajuste fiscal e implementação de políticas públicas}

O governo de Fernando Henrique Cardoso (FHC) começou com uma agenda política definida. Cardoso fora responsável pela introdução, bem sucedida, do plano de estabilização monetária - o Plano Real - no governo de Itamar Franco (1992-1994), que reduziu a inflação e foi fator crítico para sua eleição à Presidência da República. A sustentabilidade do Plano, a estabilidade da economia e o controle de inflação eram, portanto, elementos-chave do novo governo e implicaram a adoção de uma série de medidas como a privatização de empresas públicas, a diminuição da dívida subnacional (dos estados e municípios), a introdução do ajuste fiscal, a liberalização do mercado, a reforma administrativa do Estado, entre outras.

Nesse contexto político-econômico, ao seu governo coube dar continuidade (ou o início, em alguns casos) à implementação das políticas públicas, marcadas pelas diretrizes da Constituição de 1988: a universalização das políticas sociais, a autonomia do município como novo ente federativo, a descentralização e a participação da comunidade. Em alguns momentos e dimensões, o perfil das reformas entrou em choque com os preceitos constitucionais. Por exemplo, no que se refere ao papel da sociedade civil, que foi enquadrada pelo governo em termos da prestação de serviços para os setores de políticas públicas e não na participação na gestão.

$\mathrm{O}$ pacote de reformas e medidas do governo de FHC encontrou o novo sistema de saúde em processo de implementação, sob a regulamentação da terceira Norma Operacional Básica (NOB), emitida pelo Ministério da Saúde, e cujos termos expressavam a presença do Movimento pela Reforma Sanitária na sua elaboração. A NOB 1993 descentralizava a gestão da política setorial aos estados e municípios ao adotar o repasse automático de fundo para o fundo. Obteve bons resultados: a adesão dos municípios aumentou consideravelmente, comparado com a taxa de 
adesão à NOB anterior: quase 63\% em 1996 contra 22\% em 1993 (Arretche, 2001: 447). A adesão se deu essencialmente no nível de atenção básica, e somente 144 municípios aderiram à gestão de maior complexidade (Arretche, 2005: 298). Outro traço importante da Norma foi a importância atribuída à instalação dos Conselhos de Saúde e, conseqüentemente, ao controle dos poderes Executivos pela sociedade civil organizada e pelos usuários de saúde: a NOB 1993 condicionava a adesão ao SUS dos estados e municípios à instalação dos Conselhos.

As reformas do governo de FHC avançaram com base no "expressivo fortalecimento do controle exercido pelo âmbito federal", e as áreas sociais do governo nacional, nas quais se visava a redução de pobreza, foram submetidas a insulamento (Melo, 2005: 865). Em termos de recursos, o governo preferiu dar apoio às propostas de assegurar a verba via fundos de emergência que poderiam ser alocados livremente pelo Executivo, ao invés de formas de vinculação mais estáveis (Melo, 2005: 870). As reformas sociais do governo de FHC implicaram ainda a inclusão de novos dispositivos na Constituição na medida em que a Carta determinava certas políticas públicas e a implementação de alternativas a elas exigia necessariamente sua modificação (Couto; Arantes, 2006: 42): “[a] maior parte das iniciativas na política social e redução da pobreza foi implementada [pelo governo de FHC] via emendas constitucionais, o que envolveu intensas negociações dentro da coalizão governamental e com a oposição" (Melo, 2005: 860).

As reformas de cunho administrativo conduzidas por Bresser-Pereira (1997), no Ministério da Administração e Reforma do Estado, atribuíam outros significados aos princípios que embasaram as novas políticas sociais na Constituição de 1988.

De acordo com sua proposta, o processo decisório seria delegado às agências centrais estratégicas, e a descentralização abrangeria apenas a execução dos serviços. Esta, por sua vez, seria delegada às organizações públicas não estatais, diminuindo o envolvimento do Estado nas atividades tidas como não exclusivas. O princípio da participação da comunidade seria restringido ao controle das organizações provedoras de serviço, enquanto as questões políticas seriam submetidas à consulta popular para referendar ou orientar as decisões dos representantes eleitos democraticamente (Bresser-Pereira, 1997). As medidas concretas, implementadas com certo grau de sucesso, recentralizavam o poder do executivo federal e buscavam 
delegar a provisão de serviços fornecidos até então pelo Estado às organizações privadas sem fins lucrativos ou organizações públicas de direito privado (Melo, 2008).

\subsection{Alteridade em ação}

O caráter das reformas e da política econômica do governo de FHC é lido pelo movimento, como veremos a seguir, na chave do embate. O Movimento pela Reforma Sanitária reage a um contexto que considera hostil à sua proposta com eventos de mobilização, debates e novos formatos organizacionais.

\subsubsection{Diagnóstico e prognóstico do Movimento pela Reforma Sanitária: "era neoliberal"}

Os termos do diagnóstico e prognóstico do Movimento pela Reforma Sanitária produzidos no governo Fernando Henrique Cardoso guardam certas semelhanças com os do período anterior: a política econômica adotada pelo governo ameaça o Sistema Único de Saúde (SUS) nas suas diretrizes constitucionais e, por isso, os atores afirmam sua posição como defensores árduos da Lei Magna.

Em 1995, o Centro Brasileiro de Estudos de Saúde (Cebes) alertava no editorial de sua revista, a Saúde em Debate: “O SUS sob ameaça" (Paim, 2008: 204) e, um ano depois, a Plenária Nacional de Saúde, que agrupava as entidades do Movimento pela Reforma Sanitária, desencadeava uma campanha intitulada, significativamente, "SOS SUS". O pedido de socorro correspondia às situações de risco, perigo e crise na qual se encontrava o Sistema Único de Saúde, na visão dos atores do movimento. A causa dessa condição está bem clara no diagnóstico produzido na época pelo movimento: a política econômica do governo federal. A despeito dos avanços (institucionais, legais, nos indicadores e na implementação dos preceitos constitucionais), argumentava-se nos documentos, o SUS, as suas instituições e condições sanitárias estão em grave crise (Carta da X Conferência Nacional de Saúde, 1996: 13) provocada pela política econômica "de cunho neoliberal 
implementada pelo governo federal e parte dos governos estaduais" e que “estabelece-se, de fato o "Estado Mínimo" para as políticas sociais e o Estado Máximo" para o grande capital financeiro e internacional" (Carta da X Conferência Nacional de Saúde, 1996: 13 ).

Os atores identificam no Estado dois espaços institucionais que geram mudanças radicais no SUS, pervertendo os preceitos constitucionais, sejam estes, a área econômica do governo federal e o Ministério da Administração e Reforma do Estado (MARE). Ambos provocam o "desfinanciamento constante e perverso", o "desmanche dos serviços públicos" e a "privatização do Estado", nos termos da “Carta de Brasília do XIII Encontro do Conasems”, ou, na interpretação mais radical da Plenária Nacional dos Conselhos de Saúde, “a terceirização, privatização, quebra da estabilidade, inexistência de isonomia salarial, redução sistemática e crescente dos recursos financeiros da Saúde, eliminação do controle social, substituindo a visão social da saúde por uma lógica de Mercado" (Manifesto da II Plenária Nacional dos Conselhos de Saúde, 1997: 45). A área econômica e o MARE constituem centros defensores e articuladores de uma proposta excludente, segundo o Movimento pela Reforma Sanitária, e que "privilegia a minoria em detrimento da qualidade de vida da maioria da população brasileira" (Manifesto da II Plenária Nacional dos Conselhos de Saúde, 1997: 45), além de ser contrária aos princípios do SUS, sejam estes, a equidade, a integralidade, a intersetorialidade, o controle social, a gerência única e a descentralização (Carta de Brasília, 1997). Com base nesse diagnóstico, e sempre reconhecendo que, apesar da crise, o SUS ainda assim é "o exemplo mais importante de democratização do Estado" (Carta da X Conferência Nacional de Saúde, 1996: 13), os atores apresentam uma pauta de luta ampla e, ao mesmo tempo, específica: repudiar e se manifestar contra qualquer tentativa de desconfiguração do SUS cuja legalidade e legitimidade repousam na lei constitucional, e lutar pela garantia de fontes estáveis de recursos. Como pauta norteadora das ações apresentase:

Consideramos inaceitável que sete anos após aprovação das Leis Orgânicas da Saúde não se tenha ainda resolvida a questão do financiamento suficiente e definitivo para o SUS. Por isso reafirmamos nosso irrestrito apoio a proposta de emenda constitucional de no 169 , que determina a vinculação de recursos para a saúde: no mínimo $30 \%$ do orçamento da Seguridade 
Social e 10\% dos orçamentos fiscais da União, Estados e Municípios (Carta de Brasília, 1997: 35).

\subsubsection{Eventos e atores do Movimento pela Reforma Sanitária}

Simpósios, Plenárias, Atos-show... No governo de FHC os eventos conjunturais cresceram em comparação ao governo Collor. Outra característica distintiva do período são eventos temáticos, ainda que eventuais, e que em boa parte correspondem aos temas das conferências nacionais que, com a exceção da Conferência Nacional de Saúde, não foram convocados nesse governo.

Os Simpósios sobre a Política Nacional de Saúde são eventos organizados pelo Movimento pela Reforma Sanitária em momentos percebidos como especialmente nevrálgicos politicamente, sempre nas dependências do Congresso Nacional. Pelo seu caráter extraordinário e importância política, reúnem ao mesmo tempo grande número e diversidade de atores, e o movimento usa essa mobilização combinada à aliança com parlamentares para exercer pressão em cima do Poder Executivo (Santos, entrevista, 2005). Os Simpósios foram organizados duas vezes: uma vez por conta do financiamento, em 1995; e outra em 1998, quando o Ministro da Saúde, José Serra, propôs um plano de acesso a serviços de saúde de baixo custo à disposição da população como forma alternativa ao SUS. O depoimento a seguir de um militante evidencia de que maneira esses eventos de mobilização no Congresso funcionavam em prol do projeto do movimento:

O Simpósio [sobre a Política Nacional de Saúde] convocou o Serra e ele não foi. Mas, em plena execução - com 600 pessoas no auditório do Senado -, a pressão sobre o Serra foi muito grade por parte dos senadores. Aí o Serra foi no Simpósio e fez um discurso em defesa desse plano para a classe média baixa urbana. A pauleira foi total em cima dele, dos profissionais da saúde e dos usuários. Por maioria esmagadora rejeitaram e fizeram um pedido em coro para retirar a medida provisória. Serra falou uma frase antológica que diz quem ele é - um economista do mal: 'Está bom! Vocês querem que retiremos a medida provisória, nós a retiramos. Então tome SUS!' A visão de economista do mal dele é que o SUS vai ser o castigo para quem não quis entrar no plano privado. 'Então tome SUS'. Essa frase está gravada (Santos, entrevista apud Observatório, 2006: 77).

Ainda entre os eventos conjunturais, surgem no cenário as Plenárias Nacionais de Conselhos de Saúde, convocadas dez vezes entre 1995 e 1999, sempre em Brasília, 
para acompanhar a tramitação das leis que colocavam o SUS em risco e aquelas que o favoreciam. São eventos que mobilizam até mil pessoas, entre os quais conselheiros de conselhos estaduais e municipais de saúde, principalmente representantes dos usuários (Drummond, entrevista, 2005). Sua força numérica - “o grito do povo em Brasília" - é aproveitada pelo movimento para fazer lobby no Congresso e exercer pressão sobre o poder Executivo. Uma tentativa de criar ressonância na sociedade e provocar maior mobilização, por sua vez, foi a realização, dentro da campanha denominada "SOS SUS", do "Ato Show Nacional em Defesa da Saúde Pública para todos, financiamento permanente e implementação do SUS", em 16 de abril de 1997. Realizado pela Plenária Nacional de Saúde em busca (frustrada) da repercussão da crise do financiamento no setor de saúde na mídia, o evento ganhou um formato inédito no qual a reunião das lideranças do movimento se mesclou com um show artístico.

Logo depois do impeachment de Collor, foram organizadas várias conferências nacionais temáticas cuja realização fora impedida por Collor. No governo de FHC, os temas das conferências voltaram a ser debatidos por meio de seminários pontuais, novos congressos e fóruns esporádicos, organizados pelo movimento ou dos quais seus atores participaram. Entre eles pode-se citar o Congresso Internacional Mulher, Trabalho e Saúde, o Seminário Nacional sobre a Formação de Recursos Humanos, o Seminário Nacional de Vigilância Sanitária à Saúde, o Seminário Nacional sobre a Formação de Recursos Humanos em Saúde, o Congresso Brasileiro de Saúde Bucal Coletiva e os Fóruns Nacionais de Ciência e Tecnologia em Saúde. Uma parte desses eventos - a saúde bucal, mulher e saúde, ciência e tecnologia em saúde, recursos humanos - repõem exatamente a temática das conferências nacionais, que não foram organizadas no primeiro mandato de FHC.

Por fim, uma série de eventos dos atores do movimento do período anterior se manteve. Entre eles estão os organizados pela Abrasco e nos quais se repõe a tendência já observada no período anterior de integrar diversos atores do setor de saúde, da academia e da sociedade civil. Organizados em torno das temáticas e áreas de conhecimento são voltados para o sistema público de saúde: o Congresso de Epidemiologia, o Congresso de Saúde Coletiva (Abrascão) e o Congresso Brasileiro de Ciências Sociais em Saúde. Firmam-se também os eventos que correspondem a atores como a Abres com seu Encontro Nacional de Economia de Saúde, e os 
Congressos da Rede Unida. Todos eles em conjunto podem ser lidos como uma aproximação entre ensino, pesquisa e serviços, reforçando a existência da estratégia da formação do campo profissional do movimento pela Reforma Sanitária. O Conasems continua se posicionando politicamente por meio das cartas de seus anuais Encontros Nacionais de Secretários Municipais de Saúde que, a partir de sua XIV edição, em 1998 assumem o nome de Congresso.

Quanto aos atores do movimento, além daqueles supramencionados como organizadores do eventos - a Abrasco, o Conasems, a Abres - passam a integrar o Movimento pela Reforma Sanitária a Plenária Nacional dos Conselhos de Saúde e a Rede Unida e deixa de existir a Plenária Nacional de Saúde.

A Plenária Nacional de Saúde, que agregava várias entidades do movimento a partir da Constituinte, nos dois últimos anos de seu funcionamento, entre 1995 a 1997, pautou sua atuação pelo acompanhamento do processo legislativo e pela mobilização de seus integrantes em momentos de necessidade de interferência no Congresso. Sofreu um paulatino esvaziamento em suas atividades de mobilizações, ainda que as reuniões de sua coordenação continuassem bastante freqüentadas. Ainda que não em clara substituição, porque as duas funcionaram por dois anos em paralelo, entre 1994 e 1995, surgiu um novo ator, a Plenária Nacional dos Conselhos Nacionais de Saúde (PNCS). Não se trata apenas de um ator novo, pois, como vimos, a Plenária também pode ser classificado como evento. Esse “ator-evento" reproduz em parte as formas organizacionais e táticas já empregadas antes pelos movimento, mas o perfil de seus participantes - conselheiros de recém constituídos Conselhos de Saúde pelo Brasil afora constitui o caráter não convencional e permite pensar no potencial mobilizatório e movimentista das instituições participativas. A idéia de reunir os ocupantes de cargos do setor público foi inspirada na organização dos secretários municipais de saúde pelo movimento que se iniciou nos anos 1970. Mas a PNCS, diferentemente dos Encontros dos Secretários, é convocada de acordo com as necessidades do tramite da lei, e essa capacidade de mobilização lembra a Plenária Nacional de Saúde principalmente nos tempos da Constituinte e do processo de aprovação da Lei Orgânica de Saúde (1989-1990), que conseguia convocar para mobilizações em Brasília no Congresso integrantes de várias entidades que a compunham. 
Conforme registrado, ocorrem nessa época os Congressos da Rede Unida, por trás dos quais aparece outro ator novo, a Rede Unida, formada pela junção da Rede IDA, apresentada no capítulo anterior, com um conjunto de novos projetos, financiados pela Fundação Kellogg. Todavia, essa composição oficial esconde um coletivo que integra instituições, entidades e pessoas que buscam a mudança na formação dos profissionais de saúde. Vários dos militantes veteranos passam a fazer parte dela como, por exemplo, Hésio Cordeiro, Jairnilson Paim, Lílian Scraiber, Dulce Chiaverini, João Marins, Gilson Cantarino, Regina Marsiglia, José Paranaguá, Francisco Campos, Eleutério Rodriguez Neto (Almeida, entrevista, 2001). Os militantes aproveitam os Congressos e as atividades coletivas da Rede Unida para se reunir e debater a conjuntura e propor articulações (Paim, 2008: 220 e 238).

A constituição da Rede Unida - uma articulação e mobilização de pessoas que perseguiam um objetivo político comum - ocorreu em julho de 1996, na cidade de Salvador (BA), e se o caráter dos projetos e seu financiador ofereciam condições para mantê-los conectados, a constituição da Rede Unida se deu na presença de outras vários atores de universidades e outras instituições de pesquisa e ensino, movimentos populares, entidades sindicais que se integraram à Rede. Sua forma organizacional aberta guarda semelhança com a PNCS por não ter se constituído como uma entidade formal, resguardando com isso sua capacidade de agregar entidades, instituições, grupos e indivíduos que compartilham o objetivo de formar os profissionais para o SUS e com isso precisam se defrontar com o domínio de agência do setor educacional.

\section{3 Estratégias em prática}

Com a segurança do arcabouço legal do SUS estabelecido e o processo da implementação do novo sistema em curso, por um lado, e diante de um governo que introduz um conjunto de diretrizes e reformas, por outro, o movimento se coloca em posição de alerta e se prepara para uma nova frente de reivindicações, optando pelo 
caminho institucional. A garantia de recursos adicionais e estáveis para o setor é a sua pauta, ao mesmo tempo em que os atores precisam se precaver contra as medidas do governo que consideram prejudiciais ao SUS.

Na esteira da estratégia do caminho institucional, escolhemos o episódio no qual o movimento recorre, pela primeira vez, ao Ministério Público Federal para se defender das ações das instâncias do Poder Executivo contra o setor de saúde, fazendo o uso da tática de accountability horizontal. Também pela novidade, desta vez do ator, e pela importância da pauta de financiamento para o movimento, dedicamos uma secção que capta o processo de constituição da Plenária Nacional dos Conselhos de Saúde, que possui uma forma organizacional peculiar, e sua atuação no Congresso.

A atuação do movimento no interior da estratégia de formação do campo profissional, como vimos no capitulo anterior, era restrita a experiências pontuais e projetos. Nem por isso, o movimento a deixou de lado. Observamos no período a constituição de um novo ator, a Rede Unida. O processo de sua atuação, descrito a seguir, se mostra interessante do ponto de vista de disputa pelo domínio de agência na formação de profissionais com o setor educacional e das táticas escolhidas pelos atores o movimento no contexto no qual o arcabouço institucional de instituições participativas já está operando.

\subsubsection{Estratégia de caminho institucional}

\subsubsection{Estado contra Estado: tática de accountability horizontal}

Em meados dos anos 1990, Gilson Carvalho, militante do movimento, escreveu uma série de artigos que continha duras críticas ao Ministério da Fazenda, pois na época “o grande adversário de saúde não era o ministro da Saúde, era o ministro da Fazenda". O sanitarista assinava os artigos como Gilson Carvalho Cidadão Brasileiro. Esse cidadão ocupava na época (governo de Itamar Franco) o importante cargo de secretário nacional de assistência à saúde no Ministério da Saúde e "não podia aparecer". Também não "podendo aparecer" como membro do 
Poder Executivo, mas sempre militando, Gilson, junto a outros ativistas, tomou parte numa ação "via instituições" inédita no repertório do movimento, quando o setor de saúde sofreu, em 1993, uma abrupta perda de verba. Tal perda deveu-se a uma decisão ocorrida, não se sabe ao certo, em algum lugar entre o Ministério da Previdência e o Ministério da Fazenda (Paim, 2008). Conta Gilson:

E nós fomos atrás do Ministério Público. Como vocês podem ajudar a gente? O Ministério Público tinha mudado de papel na Constituição. Antes ele era um Ministério Público que defendia o Estado contra o cidadão [...] Para defender o Estado contra o cidadão foi criada a AGU, a Advocacia Geral da União, e o Ministério Público ficou como defensor do cidadão mesmo que fosse contra o Estado. E eu não podia aparecer porque eu era do Ministério da Saúde. Eu era do segundo escalão do governo, como é que eu apareço? (Carvalho, entrevista, 2012).

Em 1993, o Ministério da Previdência e Assistência Social apropriou-se de uma verba originalmente destinada ao setor de saúde, apropriação esta motivada pela decisão do Supremo Tribunal Federal, a qual determinava o reajuste das aposentadorias. Diante da falta de repasse, na ordem de 30\% (Barros; Porto 2002), diversas entidades do setor de saúde recorreram ao Ministério Público Federal (MPF) com base numa representação na qual alegavam que os preceitos constitucionais relacionados à saúde como direito do cidadão e dever do Estado não estavam sendo cumpridos pelo governo federal.

O recurso ao MPF pautava-se no novo papel desempenhado por essa instituição, o de fiscalizar os demais poderes do Estado, conquistado na Constituição de 1988 (Arantes, 2002). O Ministério Público (MP) ganhou, então, o estatuto de um poder independente, tornando-se um ator político desenvolto de ações contra os demais poderes. As garantias constitucionais dessa função de controlar e sancionar outros poderes do Estado (accountability horizontal) foram regulamentadas justamente em maio de 1993, com a Lei Complementar número 75, que dispunha sobre a organização, as atribuições e o estatuto do Ministério Público, além de, entre outros, regulamentar o uso do inquérito civil. Por meio desse, o MP poderia requisitar de qualquer organismo público ou particular informações que 
considerasse necessárias, e essas informações teriam de ser prestadas sob pena de crime, no caso da omissão ou retardamento81(Arantes, 2002: 72 e 73).

O documento das entidades de saúde chegou às mãos de uma procuradora do Ministério Público Federal para a qual nem a resposta e tampouco os procedimentos a serem empregados ainda não estavam claros:

nós nos reunimos todas as tardes durante um mês estudando esse assunto. Como será o objeto de uma investigação por parte do MPF? Se eu apurar tais coisas, que instrumentos tenho para corrigir isso? Se eu me deparar com uma omissão administrativa ou uma omissão legislativa, algo desse gênero, o que eu posso fazer com isso? (Dodge, apud Brasil/MS/SEGEP, 2006: 186).

A lei complementar lhe dava a possibilidade de se valer do inquérito civil, esse "poderoso instrumento de investigação" que confere ao MP "poder irresistível de requisitar informações e documentos para instruir suas ações" (Arantes, 2002: 73, grifo do autor).

A disposição dos procuradores do MPF em levar a demanda das entidades de saúde adiante não foi fruto do convencimento dos sanitaristas ou decorrência do perfil pessoal dos integrantes do MP. Como Arantes indica em seu trabalho, "Ministério Público e Política no Brasil", a independência institucional que permitiu ao MP ampliar suas atribuições foi calcada na justificativa da incapacidade da sociedade brasileira de controlar o Estado e

[...] os próprios integrantes do Ministério Público, imbuídos da convicção de que devem se tornar defensores da sociedade 82 , desenvolveram ações dentro e fora de seu círculo normal de atribuições, com vistas a transpor as fronteiras do sistema de justiça stricto sensu e invadir o mundo da política ${ }^{83}$. (Arantes, 2002: 15).

${ }^{81}$ A Lei Complementar $n^{\circ} 75$, de maio de 1993, considerava a saúde como um serviço de relevância pública e por isso suscetível de ação do MP.

${ }^{82}$ Arantes indica as origens endógenas dessa postura. Para conhecer a o processo de reconstrução institucional do MP e o modo como esse vem desempenhando suas novas funções políticas, ver Arantes, 2002.

${ }^{83} \mathrm{~A}$ independência institucional foi acompanhada pela funcional, segundo a qual o funcionário do MP não pode ser demitido, nem removido e seu salário não pode ser reduzido. Essas garantias foram realizadas pela Constituição e fazem toda uma diferença na atuação dos promotores (Arantes, 2002: 80). 
Foram instalados dois inquéritos pela procuradora Dodge: um que pretendia examinar as questões relativas ao financiamento e outro que se referia ao funcionamento do Sistema Único de Saúde, com ênfase na questão do controle social. Um ato solene marcou o lançamento dos inquéritos na presença das entidades que haviam recorrido ao MPF e, a partir desse momento, o movimento começou a trabalhar, ombro a ombro, com o procuradora encarregada. O MPF não dispunha de recursos institucionais (tais como, verbas, peritos) para a implementação dos dois inquéritos e se voltou com essa necessidade às entidades do setor de saúde. Uma equipe de seis pessoas indicadas, entre os quais, dois sanitaristas, Gilson Carvalho e Maria Luiza Jeager, apoiaria, de maneira voluntária, a procuradora na construção dos instrumentos dos inquéritos durante os anos seguintes.

O produto imediato de trabalho do MPF resultou nas constatações a respeito do financiamento de sistema de saúde, julgando como improcedentes os fatos ocorridos. Assim, concluía-se que não era legítima a concentração de verba em uma das áreas da Previdência Social em detrimento da saúde, como acontecera em 1993 no caso das aposentadorias. Afirmava-se que era ilícito que o orçamento anual de saúde arcasse com os juros do serviço da dívida motivado pela emissão de títulos do Tesouro Nacional (Dodge, entrevista, 2005). Ambas as constatações possuíam validade legal para os casos semelhantes no prazo de cinco anos, protegendo o setor de saúde contra esse tipo de investida por outras partes do Estado. Esse era o veredito do MPF em relação ao Executivo Federal, ao qual o Ministério não se restringiu. As ações seguintes relacionadas com a questão dos recursos se originaram na demanda dos atores do movimento e estavam alicerçadas na prerrogativa de ação do MP de requisitar as informações:

Havia no âmbito do Conselho Nacional de Saúde uma demanda veiculada por muitos segmentos organizados do movimento da saúde, apoiada pela participação de Elias Antônio Jorge e do Gilson Carvalho, que consistia em criar um sistema que fosse transparente para todas as unidades federativas do SUS, que nasceu com o nome de SIOPS. Mas havia muita resistência do Ministério da Saúde em confiar na importância disso e em assumir, no âmbito político, um sistema de informação dessa natureza. E havia um empecilho federativo porque o ministro da Saúde não podia requisitar informações das unidades para inserir nesse sistema (Dodge, apud Brasil/MS/SEGEP, 2006: 188). 
O Sistema de Informação sobre o Orçamento Público de Saúde ao qual faz referência a procuradora, quando menciona a sigla SIOPS, é um sistema de controle dos fluxos financeiros entre os três níveis federativos no setor de saúde que foi construído no MPF junto com o grupo de sanitaristas e especialistas. O cerne do sistema consistia em detectar a arrecadação e o gasto efetivos; tratava-se de verificar se os repasses estavam sendo cumpridos e se, de fato, a verba destinada à saúde era aplicada nos serviços do setor. Por exemplo, com base no SIOPS seria possível seguir o fluxo de dinheiro que saiu como recurso de saúde da União, mas que se tornava um "dinheiro genérico", podendo ser aplicado em qualquer outra política pública. $\mathrm{O}$ MPF aproveitava sua prerrogativa de requisitar as informações e exigir seu fornecimento a todas as unidades federativas sob pena de sanção, enquanto os "peritos" do Movimento Sanitário desenhavam o programa, indicando os tipos de informação necessários para se obter o quadro de fluxos dos recursos e como as informações deveriam ser fornecidas. O seu conhecimento e a experiência advinda da gestão de serviços foram a chave para a construção de um sistema capaz de levantar os dados reais essenciais.

Foram feitos testes em alguns municípios que se dispunham a participar do piloto e, assim que o questionário estava pronto, o escritório de Raquel Dodge transformou-se em uma Central de Expedição dos Ofícios, onde eram datilografadas as cartas dirigidas a todos os prefeitos do país,

requisitando que preenchessem tal questionário e devolvessem em tal data, identificando a autoridade responsável pelo preenchimento, de forma que se houvesse uma imprecisão ou uma deliberação de falsear dados eu pudesse promover uma medida [penal] nesse sentido (Dodge, Brasil/MS/SEGEP, 2006: 186).

A ideia, segundo a procuradora responsável, não era a promoção da repressão penal, mas assim foi interpretada, gerando desconfiança e resistência entre os estados e munícipios. Assim, foi preciso fazer um trabalho de convencimento por meio de visitas e seminários desenvolvidos pela Fiocruz. Para o próprio MP, trabalhar no sentido da promoção de um serviço público de modo a dotá-lo de mecanismos que 
propiciassem o aprimoramento de seu funcionamento, no lugar de ações de repressão, era também uma novidade ${ }^{84}$ (Dodge, entrevista, 2005).

O SIOPS não permaneceu apenas como instrumento de ação do MPF, como fornecedor de dados para cumprir a finalidade do inquérito. $\mathrm{O}$ sistema instalava a possibilidade de tornar visíveis, do ponto de vista dos fluxos e destinos financeiros, o que ocorria com a saúde nos estados e municípios. Para o movimento, o sistema de informações tornou-se a fonte de dados com a série histórica capaz de mostrar quanto cada parte da federação estava gastando no setor, servindo na luta pela vinculação dos recursos ao longo dos anos seguintes. O SIOPS foi transferido para o Ministério de Saúde na gestão de José Serra, adotado como instrumento de gestão, baseado na portaria conjunta entre o Ministério da Saúde (MS) e MPF que reforçava a obrigatoriedade da prestação de informações ${ }^{85}$ pelas unidades da federação ao executivo federal. O SIOPS condizia com a tendência de centralização do poder e controle sobre os gastos das unidades subnacionais que caracterizavam o governo de FHC.

Outra atuação do MPF, em articulação com os sanitaristas, envolveu o segundo pilar constitucional do SUS, o controle social. Ainda em 1993, para responder a pergunta acerca da existência dos mecanismos de controle e sua efetivação, a equipe enviou a todos os estados e a uma amostragem de municípios o pedido do envio das leis que instituíam os conselhos, bem como das atas das reuniões. Com base nas respostas, o MPF respondia negativamente a questão, observando que a efetivação dos conselhos correspondia às localidades onde os movimentos de saúde estavam presentes. Essa constatação gerou uma ação duradoura nos Ministérios Públicos nos estados, que começaram a monitorar o controle social. Esse engajamento do MP na saúde resultará na fundação da Associação Nacional do Ministério Público de Defesa de Saúde (Ampasa) que se

${ }^{84}$ Tratar de um direito social, quando a abordagem tradicional era tratar de direitos civis e políticos, tornando-o objeto de exigibilidade era uma daquelas ações.

${ }_{85}$ "O SIOPS foi formalizado como instrumento de gestão do Ministério da Saúde, com a publicação da Portaria Conjunta MS/ Procuradoria Geral da República $n^{\circ}$ 1163, de 11 de outubro de 2000, posteriormente retificada pela Portaria Interministerial $n^{\circ} 446$, de 16 de março de 2004. O banco de dados é alimentado pelos Estados, pelo Distrito Federal e pelos Municípios, através do preenchimento de dados em software desenvolvido pelo DATASUS/MS, que tem por objetivo apurar as receitas totais e os gastos em ações e serviços públicos de saúde". (http://cvirtual-economia.saude.bvs.br/tikiread_article.php?articleId=406 acessodo em 17 de janeiro de 2012). 
tornará um dos atores do Movimento pela Reforma Sanitária em meados dos anos 2000.

\subsubsection{A Plenária Nacional dos Conselhos da Saúde: ator-evento}

Em 1978, quando ocorria o $1^{\circ}$ Encontro do Setor Municipal de Saúde, em Campinas, organizado pelos sanitaristas, apenas alguns deles estavam ocupando os cargos nas secretarias ou departamentos de saúde, mas esse foi o início da mobilização dos secretários municipais de saúde sob a égide do Movimento Sanitário. Em 1995, alguns sanitaristas nos cargos de conselheiros nacionais de saúde tiveram uma ideia semelhante: a de promover o Encontro dos Conselhos de Saúde, um evento voltado para os conselheiros de saúde dos três níveis federativos que estavam instalados, na época, como parte do arcabouço institucional do SUS. Esse é apenas um dos paralelos que podem ser estabelecidos entre este novo ator-evento, a Plenária Nacional dos Conselhos de Saúde (PNCS), e outras formas organizacionais e de ação que faziam parte do repertório do Movimento pela Reforma Sanitária.

Em 1995, o Sistema Único de Saúde estava sendo implementado sob a vigência da Norma Operacional Básica (NOB) de 1993 que, elaborada por vários atores do movimento, condicionava o repasse dos recursos à instalação dos conselhos de saúde, enquanto expressão do preceito constitucional da participação da comunidade. Pela taxa de adesão à NOB, que era de 63\% em 1996 (Arretche, 2001: 447), pode se dizer que os conselhos estavam instalados em mais de 2500 municípios. Os conselhos não operavam no interior de um sistema federativo como era o caso de entidades e associações do movimento, como o Conselho Nacional de Secretários Municipais de Saúde (Conasems) ou as entidades sindicais: as eleições para o conselho nacional independiam das eleições para os conselhos estaduais e municipais; não havia um processo decisório vinculante, seja de cima para baixo, seja de baixo para cima e tampouco existiam sistemas de comunicação ou espaço de encontros voltados aos conselheiros.

Essa forma de organização de unidades relativamente independentes foi percebida como oportunidade para uma nova ação coletiva e mobilização por alguns 
dos atores do Movimento pela Reforma Sanitária que estavam no Conselho Nacional de Saúde (CNS). A ideia de reunir os conselheiros foi apoiada pela Associação Brasileira de Pós-Graduação em Saúde Coletiva (Abrasco), que ofereceu o espaço de seus congressos para os dois primeiros encontros (ocorridos em 1994 e 1995), e financiou a vinda de algumas pessoas, e pelo Ipea (Drummond apud Brasil/MS/SEGEP, 2006). Não foi de imediato que esse novo evento e novo ator encontrou seu formato organizacional. No início a iniciativa era pautada pela ideia de conectar os conselheiros à imagem e à semelhança das grandes entidades estruturadas federativamente. Começou como o Encontro (1994) foi para o Congresso (1995) e se fixou como a Plenária Nacional de Conselhos de Saúde (PNCS), a partir de 1996.

Não era apenas o nome de um ator importante do Movimento pela Reforma Sanitária - a Plenária Nacional de Saúde - que foi adotado, mas o seu modo peculiar de funcionamento em termos de mobilização e formato organizacional. A adoção do formato da Plenária significava que seus organizadores dispensavam a formalização de uma entidade e, mais especificamente, a elaboração do estatuto, e significava também que a sua convocação poderia depender das necessidades de mobilização impostas pelo processo de decisão política. No início, até as regras referentes ao número de delegados por conselho não estavam estabelecidas, o que permitia chamar um grande número de participantes para interferir no processo da tomada de decisão em Brasília, criando uma "instância intermediária de pressão":

\begin{abstract}
De um lado, era bom ter Plenária com 400 pessoas muito representativas, do outro, era bom ter Plenária com mil pessoas ainda que de um determinado município chegasse um ônibus, como aconteceu muitas vezes, principalmente porque era momento de eleição, sem muito critério do número de conselheiros por conselho. Era mais para mobilizar, fazer a manifestação, após uma Plenária. Quanto mais gente, melhor (Drummond, entrevista, 2005).
\end{abstract}

Como nos tempos da Constituinte, ainda que se adaptando a outro ritmo do processo legislativo, a PNCS era um evento perpassado por uma dupla dinâmica: a de ator - um coletivo que se consubstanciava ao discutir os temas específicos relativos à vida dos conselheiros - e a de mobilização - quando esse coletivo interferia no processo político. Uma sistematização dos temas abordados entre o $1^{\circ}$ Congresso, em 
1995, e o $12^{\circ}$ Encontro , em 2004, mostra essa alternância: em $80 \%$ dos eventos o tema da implementação do SUS (funcionamento, acesso, condições, publicização, municipalização e gestão) ocupou o mesmo espaço que o tema conjuntural da época (orçamento, financiamento, Proposta de Emenda à Constituição n 169/93 e Emenda Constitucional n 29/00)86 (Brasil/MS/SEGEP: 2006: 218).

As datas e a frequência da convocação da Plenária evidenciam o propósito do evento como mobilização. Nos anos noventa, a PNCS esteve reunida nos momentos chaves do processo legislativo relacionados com a tramitação e a votação do projeto de lei número 169, de autoria do sanitarista Eduardo Jorge e Waldir Pires, no qual se previa a vinculação dos recursos de cada nível federativo à saúde ${ }^{87}$. Foram nove eventos entre 1995 a 1999 (Brasil/MS/SEGEP, 2006: 211). De forma semelhante à atuação da Plenária Nacional de Saúde, o coletivo dos conselheiros lançava mão da tática do lobby parlamentar, no qual reproduzia as formas já conhecidas. (Brasil/MS/CNS, 2006). Assim, por exemplo, em 1997, a Plenária foi convocada três vezes. Em 16 de abril de 1997, a II PNCS ocorreu em apoio à aprovação da Proposta de Emenda Constitucional (PEC) 169. Para o dia 20 de agosto de 1997 foi marcada uma nova PNCS, junto com a Plenária Nacional de Saúde. Internamente, no primeiro dia, os 400 participantes compartilharam as informações sobre as atividades de mobilização nos estados, entre as quais, a formação da Plenária Estadual de Conselhos ou Plenária de Saúde, manifestações, ou, ainda, abaixo-assinados (Brasil/MS/CNS, 2006: 49-50). O coletivo deliberou sobre o encaminhamento das ações relacionadas com o lobby parlamentar, propôs o controle dos votos de deputados e senadores, encaminhou o procedimento da colheita sistemática dessa informação e seu repasse ao Conselho Nacional de Saúde; decidiu a respeito da pressão via comissões de saúde das Assembleias Legislativas e Câmaras Municipais e marcou a próxima Plenária para a data da votação da PEC (Brasil/MS/CNS, 2006: 52). Durante a mobilização, denominada de "Manifestação Pró-SUS e pela PEC 169/93", a Plenária de 500 pessoas se reuniu com os deputados aliados, fez audiência

\footnotetext{
${ }_{86} \mathrm{O}$ funcionamento, a estrutura e a organização das Plenárias, de um lado, e a formação de conselheiros, a articulação e a comunicação entre conselhos, por outro, ocupavam 60 e 53,3\%, respectivamente (Brasil/MS/SEGEP: 2006: 218).

${ }^{87}$ A PEC 169/93 previa para o SUS 30\% do orçamento da Seguridade Social e 10\% dos orçamentos da União, Estados e Municípios.
} 
com as lideranças, pedindo a explicitação do seu posicionamento em relação à votação da PEC 169, e teve a audiência com o Ministro da Saúde, entregando-lhe um abaixo-assinando com cerca de 150 mil assinaturas a favor da proposta, centenas de moções favoráveis ao PEC aprovadas em conselhos e comissões de saúde (Brasil/MS/CNS, 2006: 54).

A última PNCS do ano foi realizada entre os dias 2 e 3 de dezembro, data para a qual estava prevista a votação do PEC 169. Os deputados envolvidos com o Movimento pela Reforma Sanitária tiveram um embate sobre a tática da votação na própria Plenária: os deputados Eduardo Jorge e Darcísio Perondi, respectivamente autor e relator da PEC 169, sugeriam adiar a votação para evitar a derrota, enquanto a deputada Jandira Feghali argumentava que "independente do resultado, o melhor seria a votação da PEC no dia 3 de dezembro, conforme previsto, aproveitando a mobilização presente nesse dia em Brasília" (Brasil/MS/CNS, 2006: 59, grifos nossos).

A capacidade de mobilização decorria da estruturação desse ator-evento, na qual é possível reconhecer as soluções encontradas por outros atores do movimento. Pouca formalização das regras possibilitava fazer várias convocações e adaptar as atividades ao contexto politico. A ausência do estatuto não significava a falta de organização interna. Também à imagem da Plenária Nacional de Saúde, foi estabelecida a coordenação, composta por representantes das cinco regiões e depois por estado, que se reunia a cada dois meses para debater a conjuntura e tomar a decisão e as providências para a convocação das próximas Plenárias e, se fossem necessárias, até mesmo das reuniões extraordinárias, em caso da defesa do SUS ou de alguma questão orçamentária (Araújo, entrevista, 2005). Não foi criada uma secretaria executiva fixa; os coordenadores da Plenária recorriam aos funcionários públicos encarregados de acompanhar o CNS nos processos administrativos e operacionais. A qualidade dessa relação dependia do governo, e durante o mandato de FHC teria sido difícil (Araújo, entrevista, 2005).

A diferença com a Plenária Nacional de Saúde é que a Plenária dos Conselhos organizava-se em torno dos cargos, isto é, em torno dos conselheiros e não a partir das entidades do movimento como aquela. Com isso se aproximava da forma de mobilização e organização dos sanitaristas que ocupavam os cargos de secretários (ver o capítulo 2 e 3), paralelo que os próprios atores estabeleciam (Araújo, 
entrevista, 2005) e que abria a possibilidade de financiamento dos eventos pelo dinheiro público tanto para financiar a viagem, quanto hospedagem, alimentação dos participantes. Era uma possibilidade, porque nem sempre os gestores municipais e estaduais apoiavam a participação dos conselheiros na Plenária. É por essa razão também que os organizadores da Plenária tiveram de insistir no reconhecimento da atividade pelo CNS ${ }^{88}$. Uma carta convite com a chancela de Brasília facilitava a barganha com os gestores municipais no sentido de apoiar a participação dos conselheiros nas atividades na capital.

A Plenária dos Conselhos introduzia na estrutura institucional de controle social uma nova relação, algo inexistente no desenho do arcabouço das instâncias participativas do SUS: uma relação entre aqueles que estavam ocupando os mesmos cargos de conselheiros de saúde nos níveis estadual e municipal. Resguardando a autonomia de cada conselho que pertencia à área de atuação de seu executivo, a PNCS, como evento, oferecia aos conselheiros as experiências tanto de compartilhar o sentimento de pertencimento nas situações de mobilização em torno da defesa do Sistema Único de Saúde, quanto de perceber a si mesmo como parte de um grupo de pessoas em mesma condição, a de conselheiro. A Plenária oferecia aos conselheiros ainda a possibilidade de debater e compartilhar suas experiências sobre a relação do conselho com a autoridade pública, o secretário e o prefeito do município, que podiam conter desde o gradiente de cooperação até o de conflito:

\begin{abstract}
A Plenária é uma grande articulação para o crescimento desse movimento. E nisso a Plenária contribui muito durante todo esse tempo. Porque no momento em que ela busca reunir e articular os conselhos de saúde de todos os cantos do Brasil, a gente vai ver que as reivindicações não são diferentes. Que o que sofre o conselheiro do conselho municipal de saúde do interior do rio Grande do Sul não é diferente do que sofre [um conselheiro) de qualquer estado do Norte, Nordeste em relação a sua função do conselheiro, ao caráter deliberativo e fiscalizador do Conselho (Araujo, entrevista, 2005).
\end{abstract}

A primeira frase do depoimento dessa ativista da PNCS ("A Plenária é uma grande articulação para o crescimento desse movimento") mostra o objetivo político que guiava as suas lideranças. O grupo de seus fundadores defendia que ela deveria

\footnotetext{
${ }^{88}$ A constituição desse novo ator-evento gerou conflitos no interior do CNS. Segundo os idealizadores da PNCS, que representavam a Central Única dos Trabalhadores no Conselho, houve resistência dos empresários e entidades de usuários à Plenária, por ela insinuar construir um poder superior ao Conselho (Drummond, entrevista, 2005).
} 
continuar sem a "institucionalização" insinuada por aqueles que defendiam a maior formalização das regras ou sua transformação em uma comissão do Conselho Nacional de Saúde. A Plenária, como projeto político de seus idealizadores, consistia em criar um movimento a partir dos conselhos pela combinação de elementos que esses ofereciam, a saber, experiência comum de seus integrantes, base organizacional, suporte financeiro e atividades de mobilização:

\footnotetext{
Uma das formas que a gente encontrou de seguir com esse movimento [de mobilização em prol da Reforma Sanitária] com o financiamento, a com estrutura, com a representatividade de base etc. foi através da Plenária de Conselhos de Saúde" (Drummond, entrevista, 2005 ).
}

A mobilização com base nos recursos públicos era uma constante nas formas organizacionais do Movimento pela Reforma Sanitária. Esses instantes de mobilização e debates eram reforçados pelas mobilizações nos estados por meio das táticas "fora das instituições" como o abaixo-assinado, o protesto pacífico ou lobby parlamentar. Ao mesmo tempo, foi desencadeada a formação dos conselheiros. Já em 1995, o coletivo da Plenária deliberava sobre a formação dos conselheiros como condição indispensável para que se efetivasse o funcionamento dos conselhos como órgãos de controle público. Afirmava-se: "Só assim [com grande esforço de preparação específica] será possível evitar que os conselhos fiquem reduzidos a um papel de ritual e de legitimador [...]" (Brasil/MS/CNS, 2006: 26). Vale reparar que esse postulado surgiu já no segundo encontro da Plenária e, embora provavelmente calcado na percepção dos conselheiros, sua formulação em termos categóricos aponta mais para o seu caráter de estratégia, a de formação do campo profissional do Movimento pela Reforma Sanitária. Na decisão da Plenária é possível entrever também a visão não convencional da formação presente no movimento: os militantes optavam pela capacitação realizada pelos próprios conselheiros (Araújo, entrevista, 2005).

O modo de funcionamento e a estruturação da Plenária Nacional dos Conselhos de Saúde mostraram como os atores aproveitaram os elementos dos repertórios de ação e organizacional que já haviam sido utilizados pelo Movimento Sanitário/pela Reforma Sanitária: a organização do evento regular, combinado com mobilização calcada no financiamento público, e o formato organizacional de pouca 
formalização que desembocavam em um ator-evento, convocado de acordo as necessidades do processo político. Com a Plenária, ficava claro que, para os atores do movimento, a estratégia do caminho institucional na etapa da implementação do SUS não podia se restringir apenas às instituições participativas como os conselhos e as conferências, ainda que essas desenvolvessem papel importante com base em seu poder institucional e legitimador, como veremos a seguir do processo da Rede Unida.

\subsubsection{Estratégia de formação do campo profissional}

\subsubsection{A Rede Unida: enfrentando o Ministério da Educação}

Em 1997, o Ministério da Educação (MEC) abriu um edital de consulta pública com o objetivo de recolher propostas para definir as diretrizes curriculares dos cursos superiores. Para os atores do Movimento pela Reforma Sanitária, tratava-se de uma oportunidade rara de influenciar a formação de profissionais de saúde. Alinhar a formação do campo profissional à Reforma Sanitária era uma das reivindicações antigas do movimento, mas que encontrava expressão apenas em experiências pontuais que se reproduziram ao longo do tempo sem nunca, no entanto, ter passado da fase de projeto. A oportunidade foi percebida pelo ator recém-constituído do movimento, a Rede Unida - uma conexão entre indivíduos, grupos, projetos, instituições interessados e envolvidos com o objetivo de formar profissionais para o SUS. Sua forma organizacional aberta e de pouca formalização, bem como a amplitude do objetivo, permitiram articular em torno do edital diversos atores, lembrando formas de atuação realizadas pela Plenária Nacional de Saúde ou pela contemporânea Plenária Nacional dos Conselhos. Na sua atuação política, a Rede Unida recorreu a uma parte do Estado contra outra instância estatal: para poder influenciar o processo da definição das diretrizes curriculares, os atores acionaram o Conselho Nacional de Saúde, o Conasems, isto é, instituições e organizações criadas pelos próprios atores do Movimento pela Reforma Sanitária. 
Na constituição da Rede Unida, que se originava da junção da existente Rede IDA com o conjunto de novos projetos do tipo de Integração Docente-Assistencial, em julho de 1996, foi proposto que a nova Rede passasse a incorporar não apenas os projetos, mas as universidades, as instituições de pesquisa e ensino e os grupos que desenvolvessem "propostas inovadoras em formação e capacitação de recursos humanos e coerente com os princípios do SUS e as pessoas que compartilhem o desejo de promover mudanças nos modelos de ensino e de atenção à saúde no Brasil”, conforme informava sua Secretaria Executiva em 1996 (Rangel; Vilasbôas, 1996: 16 e 18). A Rede, na acepção do coletivo reunido no Seminário, deveria "se conformar enquanto um ator político, no sentido de intervir sobre a formulação e execução de políticas públicas de saúde e educação, consentâneas com os propósitos de mudanças pactuados entre seus pares" (Rangel; Vilasbôas, 1996: 16 e 18). A Rede Unida se anunciava como "movimento para a formação de novo profissional de saúde" e agregava vários sanitaristas, entre os quais estavam aqueles que antes estiveram na construção de serviços públicos de saúde, como Hésio Cordeiro, Jairnilson Paim, Gilson Cantarino, Francisco Campos, Eleutério Rodriguez Neto e outros (Paim, 2008: 208), como já vimos.

A Rede Unida adotou uma estrutura organizacional aberta e de pouca formalização: não estabeleceu regras para a participação que passassem pelas clivagens profissional, setorial ou acadêmica. Sua coordenação era itinerante entre os grupos de projetos, havendo um coordenador e a secretaria executiva com reuniões periódicas nas quais se fazia “discussão e atualização de todas as frentes de atuação, para que a Rede [pudesse] ter uma atuação mais estratégica, de acordo com as prioridades estabelecidas na sua agenda" (Barbieri, 2006; 94). As oficinas, os encontros, os congressos e os canais de comunicação, como o boletim impresso e discussões via internet, eram formas de interação e serviam como instrumentos de aprofundamento das análises e definição de rumos, mas "[o]s membros individuais e institucionais tinham liberdade para tomar iniciativas e viabilizar projetos" (Almeida apud Noronha 2002: 14). (Feuerwerker at al., 2000: 13).

Entre as primeiras iniciativas desse novo ator estava a construção de um "mapa de atores estratégicos" para: 
identificar outras forças e experiências que poderiam se juntar à Rede, além de identificar atores que poderiam desempenhar um papel positivo na definição de políticas públicas favoráveis ao fortalecimento do movimento de mudanças (Feuerwerker at al., 2000: 13).

Outra ação consistiu em "identificar permeabilidade a proposições capazes de viabilizar uma política de formação e capacitação de RHS [Recursos Humanos para a Saúde] para o SUS" (Rangel; Vilasbôas, 1996: 15). Nesse caso, a Rede procurou os pontos de acesso ao Estado que os próprios atores do movimento haviam instalado na estrutura institucional do setor de saúde, tais como o Conselho Nacional de Saúde (CNS) e o Conasems, além de contatar o Conass, a Secretaria de Educação Superior do Ministério da Educação (SESU/MEC) e a Coordenação Geral de Desenvolvimento de Recursos Humanos para o SUS do Ministério da Saúde. Ao tornar sua atuação visível politicamente, a Rede foi convidada a assumir o papel de assessor do CNS no que se refere à formação e capacitação de recursos humanos em saúde para o SUS; apresentou uma proposta de substitutivo para o projeto de Lei 137, do Senador Almir Gabriel, o qual regulamentava o artigo 200 inciso III da Constituição Federal que define a competência do SUS no ordenamento da formação de recursos humanos; auxiliou também na redação da emenda à NOB 1996, que visava contemplar a questão de financiamento da formação em três níveis federativos (Rangel; Vilasbôas, 1996: 15). Para a 10ª Conferência Nacional de Saúde, realizada em setembro de 1996, a Rede preparou, em parceria com o CEBES, um número especial da revista Divulgação em Saúde para Debate, mostrando as contribuições da Rede Unida e se posicionando como ator de referência do Movimento pela Reforma Sanitária no que se refere à formação (Barbieri, 2006: 58).

Desse modo, o edital do MEC, em 1997, que abria a possibilidade da sociedade civil organizada influenciar a definição das diretrizes curriculares dos cursos superiores, pegou a Rede em estado de mobilização. Um ano antes, o MEC havia publicado a nova "Lei e Diretrizes e Bases de Educação Nacional", com a qual terminava a era de modelo de currículos mínimos a serem obrigatoriamente aplicados pelas instituições do ensino superior. O edital 04/1997 (Brasil/MEC, 1997) convidava essas instituições a apresentarem propostas para as novas diretrizes curriculares dos cursos de graduação, que "permitiriam uma flexibilidade na construção dos currículos plenos e privilegiando a indicação de áreas do 
conhecimento a serem consideradas, ao invés de estabelecer disciplinas e cargas horárias definidas" (MEC, 1997: 2). As propostas enviadas seriam consideradas pelas Comissões de Especialistas que, por sua vez, consolidariam o material a ser aprovado pela Câmara de Educação Superior do Conselho Nacional de Educação (Noronha, 2002: 10).

A informação sobre a abertura do edital foi compartilhada numa das oficinas da Rede Unida, e o coletivo decidiu explorar essa possibilidade (Feuerwerker, entrevista, 2012). Assumiu o protagonismo na articulação da proposta, que se iniciou contatando as associações de ensino na área de saúde, como a Associação Brasileira de Enfermagem (ABEn) e a Associação Brasileira de Ensino de Medicina ${ }^{89}$ (ABEM), e, onde essas não existiam, diretamente os cursos das áreas. O objetivo era colher as experiências que buscavam mudar a formação, adequando-a para as necessidades do sistema público de saúde e suas prioridades, de modo a construir uma "proposta de diretrizes que se constituísse claramente numa perspectiva para os processos de mudança na formação dos profissionais" (Feuerwerker et al., 2000: 15). A Rede buscou o apoio e suporte políticos no Conasems, que se encarregou de mobilizar o Conselho Nacional de Saúde para tomar partido no processo. (Feuerwerker, entrevista, 2012).

Não havia garantias no Edital de que as propostas fossem de fato adotadas pelas Comissões de Especialistas, e essas, como logo percebeu a Rede Unida que estava acompanhando o processo passo a passo, não levaram em conta as contribuições enviadas. A Rede exigiu a mudança na composição das Comissões e, para tanto, recorreu à influência e posição institucional que o Conselho Nacional de Saúde tinha diante do Conselho Nacional de Educação. A negociação se desdobrou em uma série de audiências públicas apresentadas como exigência do setor de saúde. Por meio delas, o processo, antes limitado ao envio das propostas, tornou-se mais aberto à influência dos atores articulados em torno da Rede Unida. O "Parecer CNE/CES n. 1133", que definia as diretrizes curriculares para o ensino em Medicina, Enfermagem e Nutrição, foi homologado em 2001, e, segundo o coordenador da

${ }^{89}$ No início dos anos 1990, a Direção Executiva Nacional Dos Estudantes de Medicina (DENEM) e, mais especificamente, a regional da DENEM de São Paulo da qual fazia parte uma nova geração de sanitaristas, articulada com o Sindicato dos Médicos, influenciou na reorganização da Abem, transformando-a uma entidade alinhada com o Movimento da Reforma Sanitária (Jatene, 2011: 84) 
Rede Unida na época, havia "enormes coincidências" entre o aprovado e a proposta da Rede Unida (Almeida, entrevista apud Olho Mágico, 2001).

A base legal foi imediatamente aproveitada pelos atores do movimento e do setor de saúde. Numa articulação entre a ABEM, a Rede Unida, a Organização PanAmericana de Saúde (OPAS) e com a contribuição da Comissão Interinstitucional Nacional de Avaliação das Escolas Médicas (Cinaem) foi criado, em 2002, o Programa de Incentivo a Mudanças Curriculares em Cursos de Medicina pelo MS, que consistia em um sistema de incentivos financeiros às instituições acadêmicas que se dispusessem a adequar a formação profissional às necessidades do SUS (Noronha, 2002: 12 ). Vinte escolas foram selecionadas das 55 que apresentaram propostas, de um total de 95 faculdades de medicina no país em funcionamento naquele ano, que formavam 7.500 médicos por ano (Oliveira et al., 2008; 337). Em 2003, uma oportunidade nova se abriu com a eleição de Inácio Lula da Silva, cujo ministro da Saúde indicou para os principais cargos diversos sanitaristas. A Rede Unida, na pessoa de Laura Feuerwerker, passou a ocupar o cargo de coordenadora de ações estratégicas de educação na saúde e, na pessoa de Roseni Sena, o cargo de coordenadora de educação profissional do Departamento da Gestão de Educação na Saúde, na Secretaria de Gestão do Trabalho e da Educação na Saúde. “Tinha um repertório [de ações e projetos de formação] a ser posto em prática. No Ministério é assim, vocês nunca sabe quanto vai durar. Então a gente disparou muita coisa" (Feuerwerker, entrevista, 2012).

O IV Congresso da Rede Unida, em 2001 mostrava o alargamento das fronteiras do "movimento para a formação de novo profissional de saúde". Um dos organizadores do evento, o sanitarista Marcio Almeida, assim descrevia o perfil do evento e dos participantes:

Não é por acaso que na apresentação do Congresso está registrado que "este é o acontecimento mais importante, no campo da formação e desenvolvimento dos profissionais de saúde, que terá lugar no Brasil neste ano de 2001". Serão cerca de 500 participantes, de todos os estados da Federação! Praticamente todos os cursos universitários da área da saúde terão representantes no Congresso. O Congresso da Rede é um verdadeiro encontro interdisciplinar e multiprofissional. Além de professores e de estudantes, estamos recebendo inscrições de gestores dos serviços de saúde, principalmente da esfera municipal, de líderes comunitários e de líderes de outros países da América Latina, interessados em conhecer a experiência brasileira de trabalho em Rede. (...) $\mathrm{O}$ tema central do Congresso é 
"Impulsionando movimentos de mudança na formação e desenvolvimento de profissionais de saúde para o SUS. (Almeida, entrevista apud Olho Mágico, 2001).

\section{Síntese}

Os anos 1990 passam-se, na visão dos atores do Movimento pela Reforma Sanitária, sob o signo da política econômica "neoliberal" conduzida pelo governo federal. Seus desdobramentos colocam em ameaça o arcabouço constitucional do SUS e distorcem a sua implementação. Fiel à sua estratégia de caminho institucional, o movimento recorre a uma tática nova no seu repertório, qual seja, uma ação "via instituições" que acionava uma parte do Estado contra outra - a tática de accountability horizontal. Isto é, o movimento entra com o requerimento no Ministério Público Federal, que se tornou fiscalizador independente de outros poderes, para solicitar o julgamento das ações do Poder Executivo que o movimento considera descordantes da lei constitucional. Cria-se uma frente de trabalho pautada, por um lado, na postura de engajamento dos procuradores do Ministério Público e sua ferramenta única de trabalho que é o inquérito civil e, por outro, no engajamento dos sanitaristas, o que resulta nas constatações favoráveis ao SUS constitucional, na criação do instrumento de controle dos fluxos de recursos nos três níveis federativos e no engajamento do MP na promoção de controle social como diretriz constitucional do SUS.

A busca incessante pela estabilidade e pela ampliação de recursos para o setor de saúde também desemboca em uma série de táticas "fora das instituições" e "via instituições", usadas de forma convencional no Congresso, como o lobby parlamentar, audiências com o Poder Executivo, abaixo-assinados e passeatas pacíficas. A novidade está na forma organizacional acionada para lançar mão do repertório de ações já conhecido. A Plenária Nacional dos Conselhos de Saúde, no período analisado, é de pouca formalização e, por isso, possui alta capacidade de mobilização aproveitada em suas convocações que acompanham as necessidades ditadas pelo processo de decisão política. Reunindo de 500 a 1000 participantes, a Plenária faz as vezes do povo em Brasília, demostrando aos tomadores de decisão a 
capacidade de mobilização do movimento em defesa do SUS. Sempre presente e numericamente forte, isto é, sempre mobilizada quando as decisões de importância são tomadas, a Plenária constitui um ator-evento. Consubstancia-se em um ator somente nos momentos em que se reúne - no evento - formando um coletivo único que não existe alhures - coletivo de conselheiros de saúde, que discute os problemas cotidianos relacionados com a implementação do sistema. Mas faz mais do que isso: como ator, imprime um caráter mobilizatório em seu evento, pautando-se na defesa do SUS e se opondo àqueles que o ameaçam, fazendo uso do repertório de ação dos movimentos sociais.

Outro coletivo novo que opta pela não formalização de sua estrutura organizacional é a Rede Unida, uma articulação de atores em torno da estratégia de formação do campo profissional, constituído em 1995. Como as Plenárias, repousa sobre uma base organizacional, os projetos financiados pela Fundação Kellogg, que possibilitam a organização dos seus eventos. Todavia, seu formato aberto propicia a participação e a mobilização de todos aqueles que compartilham os seus objetivos políticos. Com a abertura de um edital pelo Ministério da Educação mediante o qual se convidam as instituições de ensino a enviarem propostas de diretrizes curriculares - uma oportunidade -, a Rede se mobiliza e articula uma série de atores para influenciar a formação superior na área de saúde. A Rede segue as regras do edital trata-se de uma ação via instituições convencional -, no entanto, no momento em que o andamento do processo é ameaçado, recorre à audiência pública - o que constitui uma ação não convencional. Sua convocação é solicitada ao Conselho Nacional de Educação pela instituição equivalente no Ministério de Saúde, o Conselho Nacional de Saúde, tornando o processo da definição das diretrizes curriculares, antes sob o domínio de agência das instâncias do MEC, suscetível à influência dos atores do Movimento pela Reforma Sanitária. 


\section{Movimento pela Reforma Sanitária no governo Lula (2003-2006)}

\subsection{Conjuntura: expectativas, nova coalizão no poder e fomento à participação}

A possibilidade da chegada de Luiz Inácio Lula da Silva à presidência da República era cercada pelas altas expectativas dos setores que tradicionalmente estavam vinculados ou aliados com o Partido dos Trabalhadores (PT), identificado com a defesa dos interesses dos trabalhadores, com as políticas que visam a melhoria das condições de vida da população pobre e excluída e com a adoção das formas de gestão participativas nas políticas públicas. Os sindicatos esperavam mudanças no âmbito das relações entre capital e trabalho, bem como a abertura de canais de negociação com os três poderes. Estava criada a expectativa da efetivação de um sistema público e universal de proteção social, ansiava-se a ampliação de espaços de participação e a abertura dos canais de acesso ao Estado de modo a permitir a entrada dos setores da sociedade civil organizada, ligados ao PT, para participarem ativamente da definição dos rumos da política nacional.

A possível vitória do PT trazia também um clima de incerteza no que se refere às medidas a serem adotadas na política econômica pelo partido, caso chegasse ao poder. Impactava negativamente no mercado, a identificação do PT com as propostas diametralmente opostas às praticadas pelo governo anterior, o que era aproveitado pelos adversários políticos do partido. Ainda durante a campanha eleitoral, em 2002, Lula divulgou um documento intitulado "Carta ao Povo Brasileiro", no qual se comprometia a dar sequência às mesmas políticas econômicas adotadas até aquele momento, bem como a respeitar todos os contratos firmados pelo governo que então se retiravam do poder. Os primeiros discursos oficiais dos ocupantes de cargos ministeriais da área econômica, depois da vitória eleitoral, tranquilizavam o mercado na medida em que reafirmavam os compromissos do governo Lula com a estabilidade monetária, a responsabilidade fiscal e a dívida brasileira.

A vitória de Lula trouxe, pela primeira vez, para a Esplanada dos Ministérios o Partido dos Trabalhadores, e seus amplos quadros preencheram os cargos comissionados disponíveis na estrutura do Estado brasileiro (D'Araujo; Lameirão: 
2011: 97), distribuídos ainda entre outros partidos que faziam parte da coalizão, entre os quais, um dos quatro maiores partidos em termos de expressão eleitoral, o Partido do Movimento Democrático Brasileiro (PMDB). Os cargos comissionados não eram a única forma de abrir os canais de maior participação dos setores apartados do poder federal. O governo petista diferenciou-se do governo de Fernando Henrique Cardoso pela ampliação dos espaços da participação da sociedade civil em diversos setores de políticas públicas. Expandiu o uso das conferências nacionais em novas áreas, tais como: direitos humanos, cultura, juventude, mulheres, idosos, distintas opções sexuais, entre outros, promovendo nos seus dois mandados (2003-2010) 72 conferências - contra 22 convocadas durante os dois mandatos do governo FHC (SGP, 2011). O fomento significou não apenas a promoção, mas um considerável investimento para tal expansão, dado que uma Conferência Nacional, em qualquer área de política pública, é um evento cuja organização e financiamento - das préconferências, do deslocamento de delegados e de suas diárias em Brasília - ficam a cargo do governo federal. A tendência encontrou também a ressonância no setor de saúde, pioneiro no uso das conferências como espaços de participação ampla: ao longo dos dois mandatos de Lula, foram promovidas dez conferências, enquanto no governo de FHC realizaram-se quatro nessa área. O governo promoveu a instalação de 13 novos conselhos até 2006, como o Conselho Nacional de Pesca e Aquicultura (Conepe), o Conselho das Cidades (ConCidades) e o Conselho Nacional da Juventude (Conjuve), entre outros. Fomentou também as ouvidorias públicas que visavam melhorar a comunicação entre os cidadãos e o governo federal, ampliando o seu número para 124, em 2006, ante as 40 ouvidorias existentes, em 2002 (SGP, 2011). Em suma, as formas institucionalizadas de participação foram favorecidas pelo governo federal.

Cumprindo a sua promessa de campanha expressa na "Carta ao Povo Brasileiro", em termos de política econômica, o governo de Lula se aproximou do seu antecessor, principalmente no que se refere à estabilidade monetária e ao ajuste fiscal, o que gerou críticas internas ao partido e dissidências. Ao mesmo tempo, desde o princípio da gestão, fez amplos investimentos nas políticas sociais com a introdução de uma série de medidas e programas que visavam a redução da pobreza. Aumentou a capacidade de compra do salário mínimo, promoveu a ampliação do 
programa de transferência de renda e de vários outros programas sociais (Dowbor, L., 2010: 307-308), sem que isso significasse o descontrole dos indicadores da política econômica com os quais havia se comprometido. Tal disposição significava que o âmbito de manobra nas políticas sociais estava conjugado e alinhado com os compromissos econômicos do governo.

No setor de saúde, a implementação do Sistema Único de Saúde (SUS) atingiu, em 2002, 99,6\% dos municípios, o que implicava também a instalação dos conselhos de saúde em todo o país (Arretche, 2003: 333). Isso significava que 90\% dos municípios tornavam-se responsáveis pela gestão da atenção básica, adotando maciçamente dois programas desenhados pelo governo federal para esse nível de cuidado, o Programa de Agente Comunitário (Pacs) e o Programa Saúde da Família (PSF). Em 2002, 4.161 dos 5.560 municípios possuíam as equipes do PSF implementadas, oferecendo cobertura a 54,9 milhões de pessoas do total de 140 milhões de dependentes do SUS (DAB, 2007).

\subsection{Alteridade em ação}

O Movimento pela Reforma Sanitária pelo seu caráter suprapartidário também compartilhava o clima de altas expectativas em relação ao novo governo. $\mathrm{O}$ PT e a coalizão de partidos no governo federal, entre os quais, o PMDB, ao qual estavam filiados vários sanitaristas, significava a oportunidade de tentar realizar as demandas ao setor ainda não cumpridas. Entretanto, a política econômica adotada oferecia um possível quadro de ameaça ao setor público de saúde que, na visão dos atores do movimento, estava subfinanciado. 


\subsubsection{Diagnóstico e prognóstico do Movimento pela Reforma Sanitária: SUS e democracia}

O slogan consagrado do Movimento Sanitário dos anos 1980, marcado pela efervescência da transição democrática, era "Saúde e Democracia". Vinte anos depois, o movimento retoma essa associação no $8^{\circ}$ Simpósio sobre a Política Nacional de Saúde, realizado no final de junho de 2005: O processo da reforma sanitária brasileira é um projeto civilizatório, ou seja, pretende produzir mudanças dos valores prevalentes na sociedade brasileira, tendo a saúde como eixo de transformação, e a solidariedade como valor estruturante. O projeto do SUS é uma política de construção da democracia que visa à ampliação da esfera pública, a inclusão social e a redução das desigualdades (Carta de Brasília, 2005).

Essa religação do projeto do movimento à democracia se deu na época em que ocorria a "crise de mensalão", na qual o governo era acusado de comprar os votos para favorecer os seus projetos no Congresso Nacional. Associar o processo da Reforma Sanitária a um projeto civilizatório e o projeto do Sistema Único de Saúde (SUS) à construção da democracia, além de marcar a diferença com a acusação que pesava sob o governo, traz a conotação de um processo de longo prazo, que não pode ser imediatamente concretizado. Se a construção do arcabouço institucional do SUS já havia sido completada, com praticamente 100\% dos municípios operando nesse sistema, ele é apresentado como espaço possível de vivências democratizantes.

Trata-se de um potencial, porque, como sistema democrático, o SUS, apesar dos avanços, ainda apresenta falhas. O diagnóstico do movimento aponta na implementação do SUS “baixos níveis de saúde e desigualdades sociais e regionais" (Simpósio, 2005: 1) e “o subfinanciamento e distorções na estrutura dos gastos públicos influenciados pela lógica do mercado, lógica esta que não atende às expectativas de grandes contingentes da população brasileira" (Carta de Brasília 2005).

O responsável pelas distorções é referido pelos atores em termos genéricos como "simples lógica macroeconômica de valorização do capital", ou "Estado mínimo", ou ainda, a "visão predominante da política econômica" (Simpósio, 2005: 1). O conteúdo e as tendências presentes nessa política econômica estão claros no 
diagnóstico: ela é "comprometida com o Estado mínimo e o mercado e descomprometida com práticas solidárias" (Carta de Brasília, 2005); subordina "melhores padrões de vida e maior justiça na distribuição dos benefícios do crescimento econômico à lógica dos mercados, em particular à lógica da especulação financeira" (FRSB, 2005: 4). No entanto, o agente causador - o inimigo - , diferentemente do que ocorreu no período de FHC, quando os atores identificavam até as instâncias no interior do governo, é de certa forma blindado. O agente implícito dessa política é o governo, mas nenhuma instância no nível federal é identificada como a responsável pela situação que os atores se propõem a combater.

Ainda assim, a instabilidade e a insuficiência de recursos, decorrentes da política econômica, têm afetado o funcionamento do setor de saúde e resulta, concluem os atores, na inviabilidade do cumprimento da Constituição (Brasil; MS; CNS, 2007: 62).

O que é possível fazer? Qual é o plano de ação do movimento? O prognóstico divide-se em duas linhas, que apontam para a ambiguidade da posição do movimento. De um lado, os documentos, carregados com a mensagem politizada no que se refere à avaliação da situação, estão permeados por diversas reivindicações relacionadas com o processo da implementação, que abrangem as demandas mais gerais, mas incluem também as específicas, referentes à posição de um dado coletivo no setor. Por outro lado, aproveitando a conjuntura da crise de 2005, o Movimento pela Reforma Sanitária clama pela "ruptura":

O Movimento da Reforma Sanitária alinha-se prepositivamente às mobilizações sociais e políticas, pela imediata ruptura com os rumos vigentes e pelo início já da reconstrução da política econômica, rumo à construção de políticas públicas universalistas e igualitárias, eixo básico estruturante da garantia dos direitos sociais e redistribuição da renda! (FRSB, 2005: 4).

Os atores reafirmam a importância de "manter viva e articulada a aliança bem sucedida" na defesa do SUS entre aqueles que eram os seus defensores:

Milhares de novos gestores, técnicos e profissionais do SUS, nos Estados e Municípios, dezenas de milhares de conselheiros de saúde, centenas de alunos de aperfeiçoamento na área de Saúde Pública, membros do Ministério Público, parlamentares da frente Parlamentar de Saúde [que] não só resistem ao desmanche do Sistema, como conseguem vários avanços, 
ainda que insuficientes para evitar os crescentes desvios de rumos (FRSB, 2005: 4).

E estes desvios se devem ao "subfinanciamento" (Carta de Belo Horizonte, 2005). Permeia todos os documentos do período a necessidade de mobilização para resolver a questão que impossibilita a implementação do SUS constitucional.

\subsubsection{Eventos e atores do Movimento pela Reforma Sanitária}

A primeira metade dos anos 2000 no setor de saúde e no nível federal confirma a intensificação da organização das Conferências Nacionais, em comparação ao governo de FHC, mas também revela a efervescência de outros tipos de eventos, tantos dos tradicionais quanto dos inéditos, o que corresponde, por um lado, à permanência de atores do Movimento pela Reforma Sanitária e, por outro, ao surgimento de novos. As Conferências Nacionais voltam a ser convocadas maciçamente no primeiro mandato de Lula: foram realizadas sete, ao passo que apenas uma conferência no mesmo período do primeiro mandato de FHC (ou, se levarmos em consideração os oito anos de cada um dos governos, foram realizadas dez conferências no governo Lula, contra quatro no de FHC), o que corresponde à tendência geral do governo Lula de fomentar esse tipo de participação.

Entre os eventos tradicionais de caráter conjuntural estão aqueles convocados em momentos politicamente nevrálgicos com o objetivo de mobilizar, mostrar a força numérica do movimento e aglutinar seus grupos e organizações, como as Plenárias Nacionais dos Conselhos de Saúde e o Simpósio sobre a Política Nacional de Saúde. As primeiras continuaram sendo convocadas para exercer a pressão no Congresso com vistas a aprovar a legislação favorável sobre o financiamento, ainda que com frequência bem menor do que na década de 1990, adquirindo, a partir de 2005, o caráter de um evento regular. O 80 Simpósio foi realizado, em junho de 2005, na eminência da crise política do "mensalão", como meio de buscar uma ampla adesão em defesa do SUS. Cinco meses depois do Simpósio, foi realizado um Ato Público na Câmara dos Deputados com o objetivo de defender a aprovação da Emenda 
Constitucional $\mathrm{n}^{\mathrm{o}} 29$ sobre a vinculação dos recursos ao setor de saúde e exigir a ampliação de recursos para o orçamento do setor, em 2006. A mobilização desembocou na criação de uma nova entidade articuladora dos atores do movimento.

Ao leque de eventos "híbridos" que se situam entre a área acadêmica, o setor público de saúde e a comunidade, os quais já constituíam a tendência nos períodos analisados anteriormente, são adicionados novos encontros. Além dos tradicionais Congresso Brasileiro de Saúde Coletiva, Congresso Brasileiro de Epidemiologia, Congresso Brasileiro de Ciências Sociais e Humanas em Saúde, são iniciados os Simpósios de Geografia e Saúde e os Simpósios da Vigilância Sanitária, ambos sob a coordenação da Abrasco (Associação Brasileira de Saúde Coletiva). Permanece o Congresso da Rede Unida, a Associação Brasileira de Economia de Saúde promove os seus Encontros Nacionais de Economia da Saúde e, todo ano, invariavelmente, o Conasems organiza o seu Congresso, que começa, a partir de 2004, a ser acompanhado pelo Congresso Brasileiro de Saúde, Cultura de Paz e Não Violência, evento aberto ao público mais amplo, constituindo um evento de articulação com outros atores.

Desses eventos, o de maior magnitude, em termos de participação e abrangência, por congregar todas as temáticas, é o trienal Congresso Brasileiro de Saúde Coletiva. Sua oitava edição, em 2006, foi organizada junto ao $11^{\circ}$ Congresso Mundial de Saúde Pública, reunindo milhares de participantes, grande parte deles como apresentadores de trabalhos, o que constituiu o meio de financiar a participação: dos 9.680 trabalhos enviados, apenas 1300 foram recusados (FIOCRUZ, 2006: 7) e 7.533 pôsteres foram expostos no local. Como em outros períodos, os eventos são espaços de reativar as relações e reconstruir as definições compartilhadas do movimento:

\footnotetext{
A apresentação do trabalho é o oficial. Os bastidores [dos eventos da saúde coletiva] são o espaço de organização política do movimento nesses congressos. É o momento em que você difunde concepções, organiza mesas, identifica experiências novas, dá maior visibilidade a essas experiências, você combina com os companheiros, lideranças do movimento as estratégias, porque as pessoas têm mais facilidade de conseguir recursos para viajar para poder participar dos congressos. Os congressos têm sido no Brasil um momento de organização do movimento (Vasconcelos, entrevista, 2012).
} 
Surgem dois eventos regulares no cenário atrelados a novos atores, são eles os Encontros Nacionais de Educação Popular e Saúde (2003 e 2006), da Rede de Educação Popular e Saúde (Redepop), e os Encontros Nacionais do Ministério Público de Defesa da Saúde (2004, 2005 e 2006), da Associação Nacional do Ministério Público em Defesa de Saúde (Ampasa). A constituição do Ampasa ${ }^{90}$, em 2004, decorre do trabalho de procuradores do Ministério Público Federal (MPF) e dos promotores do Ministério Público nos estados em torno dos inquéritos instalados ainda nos anos 1990 (ver capítulo 5) e principalmente daquele voltado para a questão do controle social. O envolvimento de alguns procuradores resultou em maior participação, atuação e identificação com o Movimento pela Reforma Sanitária. Na 12a Conferência Nacional de Saúde, em 2003, por exemplo, os procuradores começaram a exigir do Ministério da Saúde a sua participação como delegação, e entre os promotores que integram os conselhos de saúde vários se identificam como membros do Movimento Sanitário (Medeiros, entrevista, 2005).

Outro novo ator que aparece como organizador dos Encontros Nacionais de Educação Popular em Saúde é a Rede de Educação Popular e Saúde, uma articulação entre os militantes da Educação Popular, constituída em 1998. A narrativa dos seus ativistas (Vasconcelos, 2004) identifica suas origens nos anos 1970, nos grupos de profissionais de saúde que trabalhavam junto às comunidades utilizando a metodologia de Paulo Freire, mas sua primeira atividade coletiva ocorreu em 1991. A reunião fundadora da Educação Popular e Saúde teria sido realizada em paralelo ao Seminário da Oficina Latino-Americana de Educação Popular ${ }^{91}$, e esse primeiro encontro público propiciou o surgimento de uma forma organizacional que daria o contorno ao grupo no qual estavam envolvidos profissionais de saúde e lideranças populares.

\footnotetext{
${ }^{90}$ A Ampasa não é a primeira associação dos procuradores e promotores do Ministério Público em torno das questões sociais. Aqueles vinculados às questões do meio-ambiente já estavam se mobilizando desde o final dos anos 1980 em seminários organizados pelo Ministério Público de São Paulo, participando das reuniões preparatórias para o evento mundial Rio-92, no Rio de Janeiro, e, em 1997, constituíram a sua Associação Brasileira dos Membros do Ministério Público de Meio Ambiente (Abrampa). Informações disponíveis em: <http://www.abrampa.org.br/sobre_quemsomos.php $>$, acesso em 27 de dezembro de 2011

${ }^{91}$ Organizado pela União Internacional de Promoção da Saúde e Educação em Saúde.
} 
O movimento organizou-se como a Articulação Nacional de Educação Popular em Saúde. Segundo Stotz, David e Wong-Un (2005), atores do movimento, a Articulação funcionou durante uma década como uma "frágil mas persistente relação direta e informal entre profissionais de saúde, pesquisadores e algumas lideranças de movimentos sociais para a troca de ideias e apoio" (Stotz; David; Wong-Un, 2005: 5), aproveitando a participação em eventos de grande porte do Movimento pela Reforma Sanitária como o Congresso Brasileiro de Saúde Coletiva e o Congresso Brasileiro de Epidemiologia. Em 1998, passou a se denominar Rede de Educação Popular e Saúde (Redepop) e começou a funcionar como rede virtual.

À semelhança de outros atores do movimento, a Redepop não se formalizou: possuía apenas uma coordenação que era escolhida quando os seus militantes se encontravam. Conectados pela "convicção da originalidade radical da proposta da educação popular" (Stotz; David; Wong-Un, 2005: 6), seus participantes compartilhavam as experiências da Educação Popular e Saúde implementadas pontualmente em alguns núcleos universitários, centros de pesquisa, secretarias de saúde progressistas ${ }^{92}$ e programas nacionais, como o Programa Saúde da Família e o Programa de Agente Comunitário. Vinculada à Redepop, em 2004, foi criada pelos estudantes dos cursos de saúde a Articulação Nacional de Extensão Popular (ANEPOP), que escolheu os Congressos de Extensão Universitária e os Encontros Nacionais do Fórum de Pró-Reitores de Extensão das Universidades Públicas Brasileiras (FORPROEX) como espaços para a divulgação das propostas de Educação Popular.

Além desses dois novos atores, as atividades e os documentos produzidos em torno do $8^{\circ}$ Simpósio sobre a Política Nacional de Saúde, entre eles, o "Manifesto pela Reforma Sanitária Brasileira", permitem identificar os atores do movimento do período como "veteranos", à exceção da Ampasa. Entre as entidades signatárias estavam a Abrasco, o Cebes, a Abres, a Rede Unida e a Ampasa. Todas elas formaram na época o "Fórum da Reforma Sanitária Brasileira" como articulação

\footnotetext{
92 A experiência da Educação Popular em Saúde enquanto uma política pública foi implementada nas gestões estadual de Pernambuco de Miguel Arraes (1994-1998), do PSB e nas administrações municipais de Camaragibe (PE) (1996-2004) e de Recife (2000-2004), ambas administradas pelo PT.
} 
aberta das entidades, grupos e militantes da Reforma Sanitária, tendo como questão prioritária o financiamento do setor público de saúde.

\subsection{Estratégias em prática}

Apesar do tom alarmante do Manifesto pela Reforma Sanitária Brasileira clamando pela "imediata ruptura" e apostando "nas lutas do povo" em busca de um "novo Brasil" (FRSB, 2005: 5), nada na análise dos eventos no período indica mudanças nas estratégias do Movimento pela Reforma Sanitária. No próprio Manifesto, as táticas de ação definidas, tais como, a "articulação de alianças" e a "divulgação de documentos" (FRSB, 2005: 5) traduzem a continuidade do caminho institucional como linha norteadora das ações. O que também permanece, e novamente como questão central, como já estava no governo de FHC, é a questão do subfinanciamento. Ela pauta a mais importante mobilização do período de análise, em 2005, marcada pela organização do $8^{\circ}$ Simpósio sobre a Política Nacional de Saúde, pelo lançamento de uma nova articulação - Fórum da Reforma Sanitária Brasileira - e a proposta do estabelecimento de "uma agenda renovada e ampliada de mobilização social, política e institucional pelos direitos fundamentais e pela saúde dos brasileiros" (FRSB, 2005: 1). A centralidade da questão dos recursos para o setor e a mobilização de 2005 tornaram a atuação do movimento no Congresso, mais uma vez, importantes para a análise do seu repertório.

A associação do SUS com o projeto democrático e civilizatório, no qual a mudança de valores está em jogo, descortina a importância da estratégia da formação que, dessa vez, ultrapassa a preparação dos quadros profissionais e aponta para o objetivo de disseminar os valores estruturantes da Reforma Sanitária na sociedade. O movimento se encarrega de uma tarefa civilizatória e o faz quando entra no Ministério da Saúde, numa ocupação de cargos sem precedentes. Ao assumir todos os cargos do segundo e terceiro escalão, os atores levam aos últimos limites as suas estratégias: buscam institucionalizar grande parte de suas práticas, tornam a 
formação sob a égide da Reforma Sanitária diretriz básica de todas as outras ações e usam a ação pública para mobilizar os seus adeptos.

Examinaremos, a seguir, a atuação do Movimento pela Reforma Sanitária no Congresso e no Poder Executivo, de modo a iluminar como as estratégias foram postas em prática no contexto no qual os atores do movimento estavam numa posição ambígua: aproveitando a oportunidade sem par de atuar no governo que se recusava, ao mesmo tempo, a atender a mais importante demanda do movimento, qual seja, a de aumento de financiamento nacional para o setor de saúde.

No episódio que inicia a presente seção, apresentaremos as táticas utilizadas durante a tramitação da lei cujo objetivo era garantir o aumento e a estabilidade dos recursos para o setor de saúde. O segundo episódio aproveita a ocupação de cargos sem precedentes pelos militantes no Ministério da Saúde para discutir o caráter de atuação do movimento em algumas áreas julgadas por ele importantes. A terceira parte da seção, “Estratégias em prática”, consistirá em relatar o processo de um novo ator do movimento, a vertente da Educação Popular e Saúde, que condensa de maneira clara os elementos em jogo dessa época: a mobilização dos atores, a sua entrada no Estado, a adoção de duas estratégias numa escala nacional e a busca de perenidade e permanência.

\subsubsection{Estratégia do caminho institucional}

\subsubsection{Reféns do repertório de ação: luta pelos recursos financeiros}

A demanda por maiores e mais estáveis recursos do orçamento da União para o setor da saúde é antiga e data dos tempos da Constituinte, como já o mostramos nos capítulos anteriores. Desde então, cada vez que uma lei do interesse do movimento entrava no Congresso, os atores acionavam um conjunto de ações de modo a influenciar o processo. Na própria Constituinte, recorreram a uma forma nova, a Plenária Nacional de Saúde, conseguindo abarcar um conjunto grande de atores importantes, seja em termos de representação política, seja em termos de mobilização. A Plenária fazia o lobby e mostrava a sua capacidade de mobilização 
nas próprias dependências do Congresso. Nos anos 1990, a tramitação do Projeto de Lei que garantiria as porcentagens fixas de recursos nos três níveis federativos foi acompanhada por uma nova forma de mobilização que se originava, desta vez, nos conselhos de saúde. A Plenária Nacional dos Conselhos de Saúde possuía na época uma razoável capacidade de mobilização facilitada pela ausência de critérios rígidos para a participação, a qual era explorada de acordo com as necessidades do processo da tramitação de lei do Congresso. Esse era o momento de "grito do povo" em Brasília em defesa do SUS e contra o governo de FHC, taxado de "neoliberal". Em 2003, começava uma nova batalha no legislativo para garantir os importantes recursos federais. No entanto, no processo que se arrastou durante oito anos, os atores do movimento, apesar de acompanharem o passo a passo do processo no Congresso, não criaram nenhuma forma de ação organizacional ou de mobilização nova. Recorrerem a todo o arsenal conhecido das táticas "fora das instituições" de tipo convencional, o que foi facilitado inclusive pela presença de seus militantes no Ministério da Saúde. Sem pretender explicar o resultado, que foi, na interpretação do movimento, uma derrota, a recuperação do repertório mostra um possível efeito ambíguo na ação do movimento quando se propõe a lutar contra o governo do qual, ao mesmo tempo, faz parte.

Até o ano 2000, o Sistema Único de Saúde não contava com fontes estáveis de recursos em nenhum dos três níveis da federação. A busca por elas motivou as mobilizações dos atores do movimento ao longo dos anos 1990, como mostramos no capítulo anterior. A aprovação da Emenda Constitucional (EC) no 29, em 2000, resolveu em parte essa questão, definindo as porcentagens fixas para os estados e munícipios, $12 \%$ e $15 \%$ respectivamente, mas deixou a União com uma definição aquém dos objetivos do movimento. Em vez dos 10\% das receitas correntes brutas da União, foi aprovada a correção do orçamento pela variação nominal do PIB cujo cálculo, elaborado pela equipe econômica do governo, mantinha margens para a interpretação, deixando de trazer os 10 bilhões adicionais por ano na época - ou em torno de 15\% a mais de recursos. A aprovação da EC 29 deixava também a disposição sobre a necessidade de aprovação de uma lei complementar em até quatro anos, sob a ameaça de invalidar o poder da própria emenda. Em 2003, o Movimento pela Reforma Sanitária retomava suas mobilizações em torno da reivindicação antiga 
e para assegurar as conquistas já alcançadas por meio do Projeto da Lei Complementar nº 001/2003 à EC 29, que definiria, na versão original apresentada pela deputado sanitarista, Roberto Gouveia, a porcentagem fixa do orçamento da União em $10 \%$ das receitas brutas e estabeleceria claramente o que podia ser classificado como despesa em saúde.

No primeiro ano da tramitação, em 2004, a Plenária Nacional dos Conselhos de Saúde foi convocada duas vezes, uma em maio e outra em novembro de 2004. A Plenária de maio, que reuniu 596 participantes, era de caráter extraordinário e fora mobilizada para acompanhar o processo legislativo:

\footnotetext{
Na manhã do dia 12 de maio, os conselheiros e parlamentares presentes discutiram o projeto de regulamentação da EC 29. Na parte da tarde, todos os gabinetes dos deputados e senadores foram visitados pelos conselheiros de Saúde de seus respectivos estados com um único objetivo: obter o compromisso de cada parlamentar com a regulamentação da EC 29. Um dos pontos positivos da Plenária foi a audiência com o presidente da Câmara dos Deputados, João Paulo Cunha, que recebeu uma comissão de conselheiros e comprometeu-se a trabalhar em defesa da regulamentação da EC 29, deixando claro a dificuldade que deveremos encontrar pela frente. Além dessa grande mobilização em Brasília, foi aprovada pela Plenária uma agenda de mobilização nos estados, como também o acompanhamento de todos os passos dos parlamentares nos seus estados de origem, no que diz respeito à EC 29. (BRASIL; MS; CNS, 2006: 203).
}

Como mostra o trecho, a Plenária recorreu ao lobby parlamentar convencional, ao qual já havia apelado não só a Plenária Nacional de Saúde, durante a Assembleia Cosntituinte, mas a própria Plenária dos Conselhos, ao longo dos anos 1990. A pressão seria exercida pelos conselheiros junto às casas legislativas nos três níveis federativos a partir das comissões de saúde e seguridade social, por meio do contato com a Comissão de Finanças e Tributação da Câmara dos Deputados onde o Projeto de Lei estava sendo analisado, como também junto aos parlamentares por meio de contato presencial e virtual (BRASIL; MS; CNS, 2006: 205). Repetia-se o estabelecimento da agenda nacional de mobilização pela regulamentação da EC 29, envolvendo os conselhos estaduais e municipais, da qual fariam parte o Dia Nacional de Mobilização pela Regulamentação da EC 29, marcado para o dia 4 de junho, e a organização das audiências públicas pelos Conselhos de Saúde, debatendo o tema "Processo de Regulamentação da EC 29". Em novembro de 2004, os conselheiros participantes da XII Plenária Ordinária lotaram, como em outras vezes, 
a Câmara dos Deputados no "Ato pela Regulamentação da EC 29", articulado com a Frente Parlamentar de Saúde, reivindicando a urgência da tramitação de Lei Complementar $\mathrm{n}^{\mathrm{O}}$ 01/2003.

No ano seguinte, no clima da crise política desencadeada pelas denúncias da compra de votos dos deputados pelo governo, as lideranças decidiram lançar mão do evento do movimento convocado apenas em momentos chaves. A $8^{\text {a }}$ edição do Simpósio sobre a Politica Nacional de Saúde, além de aproveitar a mobilização para exercer o lobby, visava também "testar a mobilização da sociedade, para ver se acordava", conforme depôs um dos militantes mais antigos do movimento, Nelson Rodrigues dos Santos ${ }^{93}$ (Santos, N. entrevista, 2005). Embora convocado pelos parlamentares, o Simpósio, desde a sua primeira edição em 1979, era o evento por meio do qual o movimento repercutia o seu projeto e a sua pauta de reivindicações em momentos nevrálgicos, reunindo o diverso e heterogêneo universo de organizações, vertentes e grupos que se identificavam com a Reforma Sanitária. O $8^{\circ}$ Simpósio, que ocorreu entre 28 e 30 de junho de 2005, sinalizou a mobilização nacional de um conjunto de organizações ligadas ao movimento e que se articularam no Fórum da Reforma Sanitária Brasileira. O Fórum composto pelo Abrasco, Cebes, Abres, Rede Unida e pela Ampasa, alguns meses depois, em 23 de novembro de 2005, produziu o Manifesto intitulado “Reafirmando Compromissos pela Saúde dos Brasileiros", lançado no Ato Público realizado na Câmara dos Deputados, por meio do qual exigia-se a aprovação do Projeto da Lei Complementar da EC 29. O ano terminava com a mobilização da XIII Plenária Nacional dos Conselhos de Saúde, nos dias 5 e 7 de dezembro de 2005, que repetiu as táticas da mobilização anterior: pressão junto aos parlamentares dos seus estados e audiência com os presidentes da Câmara e do Senado, aos quais foi entregue a carta aprovada na XIII Plenária (BRASIL; MS; CNS, 2008: 64). Em janeiro de 2006, o Conselho Nacional de Saúde convocava os conselheiros do país todo para a "mobilização permanente junto aos parlamentares de suas bases" e para uma mobilização pela aprovação do Projeto da Lei $n^{\circ}$ 001/2003, na Câmara, no dia 1 de fevereiro de 2006 com “intuito de gerar uma sensibilização constante para garantir a votação" (Informativo CNS, 2006: 1). Com o

${ }^{93} \mathrm{O}$ simpósio foi articulado por um pequeno grupo de militantes, técnicos, parlamenteares junto ao Cebes e à Abrasco (Santos, N., entrevista, 2005). 
mesmo objetivo, no dia 5 de abril de 2006, as entidades do Fórum da Reforma Sanitária Brasileira, em conjunto com a Frente Parlamentar da Saúde ocuparam o Plenário da Câmara.

As mesmas mobilizações, com os mesmos atores e as mesmas táticas, o uso do lobby parlamentar na Câmara, continuarão até a última votação em dezembro de 2011, em todos os momentos considerados importantes pelo movimento. Para completar o quadro das táticas e sem entrar numa enumeração de elementos repetitivos, é preciso dizer que o movimento recorreu ainda às mobilizações intituladas de "caravanas" - como nos tempos da Constituinte - padronizadas e conduzidas pelos conselhos em todos os estados e patrocinadas pelo Ministério da Saúde (2008-2009), à mobilização apelidada "Primavera de Saúde", que envolveu a passeata pacífica de mil pessoas (2011) ao Ato Público em Defesa do Sistema Único de Saúde, que consistiu numa marcha da qual fizeram parte os participantes da $14^{\mathrm{a}}$ Conferência Nacional de Saúde. O movimento acompanhou passo a passo a tramitação do Projeto de Lei 001/2003 no Congresso por meio de ações "fora das instituições" de caráter convencional. As mesmas táticas e formas organizacionais foram reutilizadas toda vez que o processo legislativo o exigisse, mas sem que algo não convencional, algo que exigisse uma resposta das autoridades, além dos procedimentos, acontecesse. O que surpreende na análise é a alta mobilização e investimento de recursos no acompanhamento do processo legislativo ao mesmo tempo em que o movimento se mostra incapaz de trazer táticas ou elementos novos. Isso sugere que o movimento acaba entrando numa situação ambígua quando está no governo - e nessa época estava ocupando todos os cargos de direção no Ministério - e, ao mesmo tempo, tem de lutar contra ele.

\subsubsection{Mobilizando o Estado em prol do movimento}

A vitória de Lula trouxe para a Esplanada dos Ministérios a coalizão do Partido dos Trabalhadores (PT) com onze partidos e, entre eles, o Partido do 
Movimento Democrático Brasileiro (PMDB) ${ }^{94}$. Esses dois partidos estiveram no comando do Ministério da Saúde e a existência de múltiplos vínculos partidários do movimento foi acionada trazendo para os cargos comissionados grupos de sanitaristas, que se "revezavam" de acordo com o partido ao qual era designada a principal agência federal de saúde ${ }^{95}$. O Ministério da Saúde, na primeira divisão dos cargos, ficou com o PT, na figura de Humberto Costa, e os militantes petistas do movimento ocuparam todos os cargos dirigentes do MS (Paim, 2008: 241). Logo depois da chamada "crise de mensalão", que provocou a queda de alguns ministros, em 2005, o Ministério foi assumido pelo PMDB, e um sanitarista veterano, José Saraiva Felipe, trouxe os sanitaristas vinculados a esse partido. Seu sucessor, José Agenor Álvares da Silva, manteve o gabinete durante o ano que ficou no MS. Em 2007 foi substituído por outro sanitarista, José Gomes Temporão, que também se cercou por vários ativistas. A ocupação de cargos, então, já havia se tornado uma tática via instituições convencional, cuja descrição nesta seção constituiria mera repetição do que já discutimos nos capítulos anteriores, não fosse a escala da ocupação. O que fazem os militantes do movimento social quando ocupam maciçamente o Estado? Acompanharemos a sua atuação em três áreas do MS, ligadas aos eventos e atores do movimento.

Os militantes do movimento ligados ao PT haviam participado da elaboração do Plano de Governo e, antes de assumir os principais cargos em 2003, fizeram uma reformulação do Ministério, criando novas secretarias, departamentos e coordenações. No contexto da reformulação, foi criada a Secretária de Gestão Participativa, que seria assumida por um dos líderes mais emblemáticos do movimento, Sérgio Arouca, que, todavia, não chegou a assumir o cargo por motivos de saúde. Essa ausência não impediu que, em 2009, o então Ministro da Saúde, o sanitarista José Gomes Temporão, apresentasse a nova "Política Nacional de Gestão Estratégica e Participativa no SUS" (ParticipaSUS). Aprovadas pelo Ministério da

\footnotetext{
${ }^{94}$ Fora o PT e o PMDB estavam na coalizão: PL, PDT, PSB, PCdoB, PR, PPS, PP, PV, PTB.

${ }_{95}$ Nos primeiros capítulos mostramos essas características pluripartidária e suprapartidária dos ativistas e organizações do Movimento pela Reforma Sanitária. Ao mesmo tempo em que defendiam o mesmo projeto para um novo sistema de saúde, público, universal e gratuito, seus militantes não compartilhavam a identificação partidária e eram filiados a diversos partidos. A tática de ocupação de cargos no Estado adotada pelos atores era potencializada pela variedade de vínculos partidários.
} 
Saúde, pelo Conselho Nacional de Saúde e pela Comissão Intergestores Tripartite (Brasil; MS; SGEP, 2009), as diretrizes da Política objetivavam "orientar" as ações nos três níveis federativos em termos de metas, formas e conteúdos, dando respaldo legal para aqueles gestores que se propusessem a fazer o uso dela. A ParticipaSUS trazia o fortalecimento das instituições participativas já construídas pelo movimento, o que era de se esperar. Seu lado não convencional consistia em introduzir como diretriz da Política a mobilização da sociedade em prol do SUS. Os militantes do movimento inscreviam no documento norteador a necessidade de mobilizações futuras de modo a garantir a constante adesão de novos segmentos em defesa do sistema público de saúde, mobilizações que, a partir de então, estariam a cargo do Estado. Criavam, com efeito, uma nova forma de ação do Estado, pautada pela lógica da atuação do movimento social - criação de relações, grupos e redes, construção da identidade coletiva e potencial para a mobilização - para aqueles momentos em que o SUS se encontrasse em situações de oportunidades ou ameaças. Conferiam, em outras palavras, ao Estado a diretriz de mobilização movimentista como instrumento de gestão.

As duas facetas, a de apoio às instituições participativas e a de suporte para as mobilizações futuras, aparecem já na dupla denominação da gestão que se pretende promover pela ParticipaSUS, que é "participativa" e "estratégica". A primeira qualificação denota os processos cotidianos da gestão SUS nos quais ocorrem a formulação das políticas e a deliberação sobre elas pelos atores inseridos nas instâncias de controle social, enquanto a segunda refere-se à "ampliação de espaços públicos e coletivos para o exercício do diálogo e da pactuação das diferenças" (Brasil; MS; SGEP, 2009: 15). As sete "formas e mecanismos" concretos enumerados pela nova Política dotam de mais detalhes a dupla caracterização. No eixo participativo são incluídas as instâncias criadas no bojo da Reforma Sanitária, que são os conselhos de saúde e as conferências de saúde classificados como "mecanismos institucionalizados de controle social", e a Comissão Intergestores Tripartite (CIT) e as Comissões Intergestores Bipartites (CIB), essas denominadas como "instâncias de pactuação entre gestores". Esses mecanismos e essas instâncias devem buscar a integração com outras instituições do SUS, tais como a "direção colegiada", as "câmaras setoriais", os "comitês técnicos", os "grupos de trabalho", os 
"pólos de educação permanente em saúde" e os "setoriais de saúde dos movimentos sociais", todos constituídos ao longo da implementação do sistema (Brasil; MS; SGEP, 2009: 17). Essa linha de integração abrange também diferentes setores do governo com a sociedade civil.

Outro eixo, que é o estratégico, visa a mobilização para o futuro, ao abranger os "processos de educação popular em saúde desenvolvidos no diálogo permanente com movimentos populares, entidades formadoras e grupos sociais no sentido de fortalecer e ampliar a participação social no SUS" e ao incluir o uso dos "mecanismos de mobilização social" para "articular os movimentos populares na luta pelo SUS e o direito à saúde, ampliando espaços públicos (coletivos) de participação e interlocução entre trabalhadores de saúde, gestores e movimentos populares" (Brasil; MS; SGEP, 2009: 17-18). Ou seja, torna o objeto da política do Estado a organização e a mobilização dos atores coletivos em prol do SUS e da defesa da Reforma Sanitária.

É o Estado mobilizando a sociedade, como o fizeram os médicos sanitaristas, nos anos 1970, na periferia de São Paulo, por exemplo, com a diferença de escala e abrangência. Com base na sua trajetória, os ativistas já sabem que a mobilização exige a preparação, a formação e os recursos. A estratégia que pauta essas formas de mobilização é a do caminho institucional e passa pela mobilização, articulação e integração entre velhos e novos atores identificados com o SUS. Os ativistas do movimento da Reforma Sanitária no MS reconhecem também que a identidade coletiva não é ponto de partida, mas algo que se constrói nos processos que envolvem diálogo, articulação e diversas formas de participação, isto é, quando são acionadas as relações entre os grupos e indivíduos. Por isso, a segunda estratégia, que desde os anos 1970 norteia as ações do movimento, a de formação do campo profissional, também é reposta na "ParticipaSUS". Adota-se a educação popular em saúde como diretriz metodológica e postula a necessidade de "mudança na educação em saúde em todos os espaços de formação com objetivo de formar cidadãos em defesa do SUS" (Brasil; MS; SGEP, 2009: 17-18). Isto é, a estratégia se amplia para além da formação dos profissionais, englobando agora todos que fazem parte do sistema. 
A transformação das linhas programáticas do governo de acordo com a visão do movimento pode ser encontrada também em mais duas instâncias do Ministério. A Secretaria de Ciência e Tecnologia e Insumos Estratégicos (SCTIE/MS) que ficou a cargo de médico sanitarista, José Alberto Hermógenes, representava a área na qual os sanitaristas têm militado desde os anos 1980, organizando eventos e tentando influenciar as linhas programáticas das agências públicas de pesquisa, investimentos em desenvolvimento tecnológicos, de acordo com as necessidades da Reforma Sanitária. Uma vez nos cargos da direção, os sanitaristas partiram para a construção coletiva da Agenda Nacional de Prioridade de Pesquisa em Saúde, em 2005 e, em seguida, ainda no mesmo ano, elaboraram e aprovaram a "Política de Ciência, Tecnologia e Inovação em Saúde". Com base nela, foi redirecionado, entre outros, o fomento às pesquisas, agora pautado pela temáticas e questões consideradas importantes para o sistema público de saúde. O MS assinou convênios com as agências de fomento como o Conselho Nacional de Desenvolvimento Científico e Tecnológico (CNPq) e a Financiadora de Estudos e Projetos (Finep), com as fundações de amparo à pesquisa estaduais e as secretarias estaduais de saúde de modo a permitir o repasse de orçamento do MS para esses órgãos financiarem as pesquisas. Entre 2004 a 2007, 2300 estudos foram financiados a partir dos editais, sendo que do total de 146 milhões de dólares, 39\% dos recursos eram de outras instituições e 61\% do MS. (BRASIL; MS; DCT; SCTIE, 2008: 774).

A constituição do Departamento de Economia de Saúde da Secretaria de Ciência, Tecnologia e Insumos Estratégicos foi, por sua vez, a tradução de um esforço associativo do movimento entrelaçado com a promoção de eventos com o objetivo de adaptar a disciplina acadêmica de Economia de Saúde como fonte de informação e instrumento de gestão nos serviços públicos. Liderada por dois sanitaristas do IPEA, Sólon Magalhães Vianna e Sérgio Piola96, técnicos da área de saúde do Instituto desde os anos 1970, e com o apoio da ENSP e da Fiocruz, a temática encontrou expressão nos encontros regulares que ocorreram a partir de 1990, e na constituição da Associação Brasileira de Economia da Saúde (Abres), em 1990. A Abres encontrou a forma de introduzir tal disciplina acadêmica como um instrumental da gestão do

96 Sérgio Francisco Piola participou do PIASS (1976 a 1978) e foi integrante do Conselho Nacional de Saúde e Sólon Magalhães Vianna fez parte da Comissão Nacional de Reforma Sanitária de 1987. 
setor público, recorrendo ao financiamento externo, do Department for International Development (DFID), ainda durante o governo FHC, negociado entre 2000 a 2002 . O desenho do projeto que abrangia alguns estados e correspondeu ao modelo praticado em outros projetos liderados pelos sanitaristas ${ }^{97}$, a saber, a integração entre o setor público de saúde e as universidades. Compreendeu a instalação de Núcleos de Economia de Saúde em Secretarias Estaduais de Saúde articuladas com os Núcleos de Economia de Saúde criados nas universidade e/ou escolas de saúde pública, com forte ênfase na capacitação dos gestores (Brasil; MS, 2007: 100). A abrangência e o escopo das ações previstas no convênio foram potencializados com a constituição, em 2003, do Departamento de Economia de Saúde no MS, quando os sanitaristas tiveram a possibilidade de redesenhar a composição do Ministério de acordo com a sua visão. Foram intensificados os eventos tais como as Jornadas Nacionais de Economia de Saúde abertas à participação para além da academia, promovidos os ciclos de debates e de informes conjunturais sobre o financiamento e economia da saúde com a transmissão via Canal Saúde e TV Câmara. Foram criadas a Rede de Economia da Saúde (Rede Ecos), rede virtual de comunicação envolvendo pessoas ligadas à ES, e a biblioteca Virtual em ES (BVS-ECOS) que reúne e disponibiliza a produção intelectual na área. (Brasil; MS, 2007: 79).

A estratégia da formação do campo profissional encontrou sua expressão também na Secretaria de Gestão do Trabalho e da Educação na Saúde e, mais especificamente, no Departamento de Gestão da Educação na Saúde no qual foram implementados diversos programas de formação superior e técnica alinhadas às necessidades do SUS pelos sanitaristas ligados à Rede Unida, como vimos no capítulo 5. No interior desse departamento, havia a Coordenação de Ações de Educação Popular na Saúde, instância nova que expressava de forma clara a principal tônica do Movimento pela Reforma Sanitária quando ocupa os cargos no governo Lula: levar às últimas consequências a prática das suas estratégias.

\footnotetext{
${ }^{97}$ Aqui pode ser citada, a título de lembrete, a criação dos Núcleos de Saúde Coletiva (capítulo 4), Projetos de Integração Docente-Assistencial (capítulo 4), Projeto Larga Escala (capítulo 4).
} 


\subsubsection{Estratégia de formação do campo profissional}

6.3.2.1 Institucionalização mobilizadora: Educação Popular e Saúde no Ministério da Saúde

Na ocupação de cargos no Ministério da Saúde em 2003, entre as diversas vertentes e militantes que alcançaram acesso ao Estado estava a Rede de Educação Popular e Saúde (Redepop), que até então não passava de um conjunto de experiências conectadas por uma rede de profissionais, técnicos, professores e lideranças comunitárias. O coletivo aproveitou a oportunidade na mudança de partido no governo federal e pleiteou a sua entrada no Estado que se concretizou mediante a instalação da Coordenação. O que faz o movimento quando, de uma hora para outra, se torna governo? Reproduz a forma de mobilização e atuação do movimento social: articula, mobiliza, promove encontros, fomenta as atividades de formação, divulga e o faz em dimensões inéditas na medida em que essa atuação agora é a ação pública, que conta com a coordenação e os recursos nacionais alocados no Ministério da Saúde. A Coordenação é um ponto de acesso e influência no Estado dos atores de Educação Popular no Estado, sujeito às mudanças no governo. Assim, para fugir dessa contingência, os atores dão um passo adiante e buscam construir um domínio de agência que possa consolidar a forma e o conteúdo de sua atuação.

Para entender, em linhas gerais, o que vem a ser a vertente de Educação Popular e Saúde, as dimensões de diagnóstico e prognóstico se mostram facilitadoras. Os atores partem da avaliação de que no setor de saúde predominam o "autoritarismo de doutor," o "desprezo pelas inciativas do doente e seus familiares" e a "imposição de soluções técnicas restritas para problemas sociais globais" e que nos processos formativos se mantém o "tradicional modelo autoritário de educação" (Vasconcelos, 2007a: 22). Este quadro é fruto do foco da preocupação do processo da

Reforma Sanitária que "ficou centrado principalmente nas questões da construção do arcabouço jurídico e institucional do sistema e no desejo de expandir rapidamente a cobertura dos serviços de saúde" (Vasconcelos, 2007a: 26) em detrimento das 
mudanças no modelo de saúde. Os atores da Educação Popular e Saúde se propõem a mudá-lo, interferindo nas micro relações da assistência à saúde que se instauram entre os profissionais e os usuários, ainda que esse foco não implique de modo algum ações pontuais, táticas subversivas ou aquelas situadas nos interstícios do sistema. Seus ativistas almejam a mudança por meio da estratégia do caminho institucional e da formação do campo profissional em larga escala, conforme afirma um de seus líderes:

Temos condições de superar a fase em que estas práticas de saúde mais integradas à lógica de vida da população aconteciam apenas em experiências alternativas pontuais e transitórias. É preciso encontrar os caminhos administrativos e de formação profissional os quais permitam que elas se generalizem institucionalmente (Vasconcelos, 2007a: 25, grifos nossos)

Com efeito, a Educação Popular não é considerada pelos ativistas apenas como uma atividade de formação, e sim "uma ação que reorienta a globalidade das práticas ali executadas [nos serviços de saúde]" (Vasconcelos, 2007a: 22) e introduz "democratização da assistência levada à microcapilaridade da operacionalização dos serviços de saúde" (Vasconcelos, 2007a: 25). Conforme vimos na secção dedicada à apresentação dos atores, a articulação entre os militantes começou a ficar mais intensa no final dos anos 1990. Em 2001, o II Encontro Nacional de Educação Popular e Saúde (ENEPS) foi realizado em conjunto com o "II Seminário sobre Educação em Saúde no Contexto da Promoção da Saúde: seus sujeitos, espaços e abordagens", na Universidade de Brasília, contando com aproximadamente 900 participantes.

A oportunidade para desenvolver as ações condizentes com as estratégias de caminho institucional e da formação se abriu com a vitória eleitoral do candidato do PT, Lula. Aproveitando a identificação do PT com a práticas de educação popular, ainda em 2002, o coletivo da Educação Popular e Saúde, apresentando-se como "uma articulação de pessoas e grupos que priorizam a Educação Popular como instrumento de transformação da assistência à saúde em espaços como os serviços de saúde, a academia, os movimentos sociais e as organizações não governamentais" 
(Redepop, 2002), redigiu um documento ${ }^{98}$ ao novo presidente da República. Na Carta explicitavam a contribuição que a Educação Popular poderia trazer para o SUS, demostrando as condições já existentes para isso e as formas de operacionalização. A proposta foi acolhida na reformulação ministerial de 2003 promovida pelos sanitaristas, e a Educação Popular e Saúde criou o seu ponto de acesso no Estado com a instalação da Coordenação Geral de Ações Populares de Educação na Saúde, do Departamento de Gestão da Educação na Saúde (DEGES) que estava subordinado à Secretaria de Gestão do Trabalho e da Educação na Saúde (SGTES).

O desenvolvimento das ações na Coordenação Geral de Ações Populares de Educação na Saúde seguiu um percurso de mobilização no qual é possível detectar a forma de atuação empregada pelo movimento em outros momentos: partiu-se do mapeamento dos atores, foram organizados os encontros estaduais, criada uma articulação nacional no formato de ator-evento e promovidas as atividades de formação de modo a construir uma conexão de atores organizados em torno dessa linha de atuação. Esse processo foi desencadeado no VII Congresso da Saúde Coletiva da Abrasco, em 2003, quando foram escolhidos os representantes estaduais para mapear e articular os atores e as práticas de Educação Popular. A primeira atividade era a promoção de um evento estadual no qual cinco pessoas seriam escolhidas para participar da reunião fundadora da Articulação Nacional de Educação e Saúde (ANEPS), em Brasília. Organizado na véspera da 13a Conferência Nacional de Saúde, o Encontro Nacional de Movimentos e Práticas de Educação Popular e Saúde foi realizado entre 5 e 6 de dezembro de 2003, contando com 250 pessoas (Stotz, 2004: 181) ${ }^{99}$. A “Articulação" se constituiu como “instância de interlocução" entre os movimentos populares, profissionais de saúde, pesquisadores e técnicos do governo. Isto é, não como uma entidade formal, mas como um atorevento: um coletivo sob a denominação comum de Educação Popular e Saúde, aberto

\footnotetext{
98 O documento era intitulado "A Educação Popular em Saúde e o Governo Popular e Democrático do Partido dos Trabalhadores: Considerações e Propostas da Rede de Educação Popular e Saúde" (Redepop, 2002).

${ }^{99} \mathrm{E}$ o trabalho de mapeamento dos novos aliados seria realizado por meio de um levantamento que resultaria no Catálogo de Movimentos e Práticas de Educação Popular e Saúde (Stotz, 2004: 180 ).
} 
para integrar outras entidades e movimentos, que se consubstancia no Encontro Nacional. Neste espaço, os participantes organizados em "rodas de conversa" sistematizam as questões e tomam as decisões.

A iniciativa da criação da "Articulação" recebeu o apoio da Confederação Nacional dos Trabalhadores na Agricultura (Contag), Direção Executiva Nacional de Estudantes de Medicina (DENEM), Projeto Saúde e Alegria/GTA, Movimento de Mulheres Trabalhadoras Rurais (NMTR), Movimento de Reintegração de Pessoas Atingidas pela Hanseníase (MORHAN), Movimento dos Sem Terra - Coletivo de Saúde; Movimento Popular de Saúde (MOPS) e a Rede de Educação Popular e Saúde. O apoio era político e se desdobrava na atuação conjunta nos estados após a primeira mobilização e o encontro nacional e consistiu na criação de fóruns permanentes estaduais de educação popular. Esses seriam, nas palavras do coordenador da ANEPS, uma forma de assegurar a continuidade deste processo que, além de desenvolver ações de saúde e de luta social, procuraria: interagir com os pólos de educação permanente em saúde; participar nos conselhos gestores, conselhos de saúde, plenárias de conselheiros e conferências de saúde; participar em audiências e consultas públicas; propor consultas populares (Stotz, 2004: 181).

Os atores do movimento entrelaçam o objetivo da mobilização com o uso dos canais e instâncias já constituídos de modo a potencializar a ação, despertar e manter a articulação viva. O desenvolvimento de ações de Educação Popular e Saúde, em Santa Catarina, mostra essa combinação e seu funcionamento na prática, conforme sistematizado por Severo, Cunha e Da Ros (2007).

Um grupo de discentes da Universidade Federal de Santa Catarina (UFSC) se encarregou da iniciativa, organizando o $1^{\text {o }}$ Encontro Catarinense de Movimentos e Práticas de Educação Popular e Saúde, entre 03 a 04 de outubro de 2003. Conseguiram reunir representantes das pastorais da saúde, agentes comunitários, Fórum Estadual Popular de Saúde, ONGs, profissionais e residentes em Saúde da Família, com o objetivo de articular os atores oriundos de diversos espaços em torno do método de educação popular e eleger uma delegação para o Encontro Nacional, a qual participaria da $12^{\text {a }}$ Conferência Nacional de Saúde, em dezembro daquele ano. Em 2004, as atividades começaram a ser financiadas pelo Ministério da Saúde por meio de um projeto que visava a "articulação em torno dos Movimentos e Práticas 
para a consolidação do SUS por meio da participação popular em todas as instâncias da rede de saúde" (Severo; Cunha; Da Ros, 2007: 214). O projeto foi operacionalizado por meio de cursos de formação e oficinas em alguns municípios nos quais se discutiam os temas de educação popular, educação permanente, concepção de Estado, sociedade civil e políticas públicas, análise de conjuntura, SUS, participação popular e a construção do II Encontro Estadual. Também os recursos do projeto facilitaram a divulgação e expansão da ANEPS, levada a cabo pelos "articuladores" municipais e regionais. O $2^{\circ}$ Encontro Estadual, que ocorreu entre 9 a 11 de junho de 2005, em Chapecó, e do qual participaram cem pessoas de 50 diferentes organizações, constituiu a Articulação Executiva Estadual que seria responsável encaminhar as propostas do evento. Logo depois, houve a desarticulação do ANEPS catarinense, atribuída à falta de recursos, à falta de apoio da base e à falta de clareza sobre o papel da Articulação (Severo; Cunha; Da Ros, 2007: 244).

Esse momento da ANEPS catarinense correspondeu à mudança do ministro da saúde, que trouxe um outro grupo de sanitaristas para os cargos dirigentes. A Coordenação de Educação Popular mudou de secretaria, tornando-se parte da Secretaria de Gestão Estratégica e Participativa e, no interior dela, do Departamento de Apoio a Gestão Participativa, tendo perdido recursos e importância, na visão dos ativistas (Vasconcelos, entrevista, 2012). Ademais, começou a ser sentida a falta de apoio e adesão das secretarias estaduais e municipais à proposta de Educação Popular e Saúde.

Os ativistas da Redepop perceberam prontamente essa vulnerabilidade e propuseram um encaminhamento de maior perenidade e capaz de ampliar as ações para os demais níveis da federação, mediante a elaboração da Política Nacional de Educação Popular e Saúde. Com a clareza de que a estratégia tinha de ser a institucionalização, a Redepop solicitou uma reunião com o Secretário a quem a Coordenação de Educação Popular estava subordinada no MS. Reivindicaram maior atenção à área e demandaram, mais especificamente, a instituição de uma comissão incumbida de elaborar a "Política Nacional de Educação Popular e Saúde". O Comitê Nacional de Educação Popular e Saúde foi instituído por uma portaria $\mathrm{N}^{\mathrm{O}}$ 1.256 do Ministro de Saúde, do sanitarista José Temporão, em 17 de junho de 2009, composto por diversos membros do Ministério e pelos atores que faziam parte da 
ANEPS. A Redepop aproveitava um recurso que já estava sendo usado por outras vertentes do movimento para construir, entre outros, a Política Nacional de Ciência e Tecnologia em Saúde, a Política Nacional de Participação do SUS, a Política de Saúde de População Negra, a Política Nacional de Atenção à Saúde dos Povos Indígenas. Se tiver a força da Lei, uma "Política Nacional", ao ser aprovada pelas principais instâncias setoriais no nível federal - o MS, o Conselho Nacional de Saúde e a CIT -, os seus princípios, os objetivos, as diretrizes, as estratégias e as responsabilidades de gestão passam a pautar os atores envolvidos com a temática, bem como a orientar a ação dos gestores públicos.

A pressão junto ao Ministério que desembocou no estabelecimento do Comitê Nacional da Educação Popular e Saúde aponta que seus atores não estavam apenas no Estado. Paralelamente ao desenvolvimento da Educação Popular e Saúde como uma política pública, também foram promovidas pelos seus ativistas ações nas universidades e, mais especificamente, na área de extensão universitária. Um dos principais mentores da vertente, Eymard Vasconcelos, havia desenvolvido os projetos de educação popular e saúde por meio da extensão universitária na Universidade Federal da Paraíba (UFPB) devido à falta de espaço para suas atividades e propostas nas principais linhas programáticas de docência e pesquisa (Vasconcelos, entrevista, 2012). Em 2003, a divulgação das experiências de extensão vividas por um estudante de medicina do Rio de Janeiro na Redepop acabou conectando muitos estudantes em torno do tema. A coletânea Perplexidade na Universidade: vivências nos cursos de saúde, escrita por vários alunos e sob a coordenação de Vasconcelos, foi fruto dessa efervescência. Logo depois, no Seminário Nacional sobre Educação Popular e Saúde, da UNB, em 2004, os estudantes dos cursos de saúde criaram a Articulação Nacional de Extensão Popular (ANEPOP). O coletivo da ANEPOP escolheu os Congressos de Extensão Universitária e os Encontros Nacionais do Fórum de Pró-Reitores de Extensão das Universidades Públicas Brasileiras (FORPROEX) como espaços para a divulgação das propostas de Educação Popular e Saúde e demandava um formato alternativo para as suas atividades. Todavia, impedido de ter influência no desenho oficial dos eventos, o coletivo instalava, paralelo à programação oficial, a forma que já fazia parte do repertório de Educação Popular e Saúde, as “Tendas de Paulo Freire”. Na 
visão das lideranças, tratava-se de uma fonte renovadora de militância na área de Educação Popular e Saúde, com potencial de mobilização e crescimento. A ANEPOP obteve, em 2010, um assento no Comité Nacional encarregado de elaborar a Política Nacional de Educação Popular e Saúde.

\section{Síntese}

O Movimento pela Reforma Sanitária esteve, no período em análise, em uma posição ambígua. Os sanitaristas ocupavam todos os cargos de direção no Ministério da Saúde, desfrutando de uma oportunidade sem precedentes para conduzir a política setorial, ao mesmo tempo em que o governo em questão, que oferecia tal oportunidade, precisava, ele próprio, ser pressionado para garantir uma fonte maior e estável de recursos, indispensável para o desenvolvimento do SUS. Por um lado, a ambiguidade influenciou o repertório de ação do movimento na sua luta no Congresso, tornando-o repetitivo e convencional. Por outro, como governo, o movimento transformou suas demandas em linhas de ação do Estado, alcançando um patamar alto da institucionalização de suas demandas e dotando a ação do Estado da lógica movimentista.

As ações fora das instituições e do tipo convencional, como o lobby parlamentar, as manifestações pacíficas, as caravanas e os atos públicos marcaram a atuação do Movimento pela Reforma Sanitária no acompanhamento do processo legislativo no qual, mais uma vez, decidiam-se os destinos dos recursos para o setor de saúde. Os atores lançaram mão das suas habituais formas de mobilização no Congresso, recorrendo tanto à Plenária Nacional dos Conselhos de Saúde quanto ao Simpósio sobre a Política Nacional de Saúde. As instituições e os espaços institucionalizados por eles construídos, como conselhos de saúde e as conferências, foram envolvidos em mobilizações a favor da lei. Foram anos a fio nos quais o mesmo repertório, o de ação e o organizacional, foi acionado todas as vezes em que os atores o julgaram necessário. Eram leitores atentos da tramitação no Congresso, mas nessa ocasião utilizaram-se do repertório apenas convencional. 
Logo no primeiro mandato de Lula, os cargos do segundo e terceiro escalões do Ministério da Saúde foram preenchidos pelos militantes do movimento ligados ao Partido dos Trabalhadores. A tática de ocupação de cargos já havia se tornado convencional e não causava polêmica no interior do movimento, como nos tempos da ditadura, quando os primeiros ativistas adentravam no "sistema inimigo" para combatê-lo por dentro. Todavia, dessa vez, a ocupação de cargos era sem precedentes desde a aprovação do SUS na Constituição. O que faz o movimento social quando se torna parte do governo? A análise de algumas áreas mostra que os atores redesenham as instâncias do Estado de acordo com as suas prioridades, adequam as ações à sua visão e criam novas que correspondem aos seus objetivos, engendram pontos de acesso e influência para tornar a sua atuação possível, além da permanência incerta no governo, e usam a ação estatal como instrumento de suas futuras mobilizações. Se o movimento se tornou o Estado, o Estado se tornou movimentista, moldado à imagem das formas de ação do Movimento pela Reforma Sanitária.

O depoimento do militante do movimento em sua vertente de Educação Popular e Saúde, sintetiza a postura dos atores no governo:

\begin{abstract}
Estou cansado de ser alternativo. Quero ser hegemônico. A institucionalização é um caminho importante para mudar, e nós queremos uma sociedade nova. Temos que estar atentos porque o Estado busca a cooptação dos movimentos. Mas nós não queremos práticas lindas, aqui e acolá... É claro que não se faz educação com portarias e gratificações mas, por outro lado, o Ministério da Saúde pode publicar 15 mil exemplares de Cadernos de Educação Popular e Saúde. Quando um movimento social vai poder bancar uma publicação deste porte? Fala-se que tudo que é instituído se congela mas eu digo que o instituinte continua (Vasconcelos, 2007b).
\end{abstract}

Estaria certo esse militante ao afirmar que o movimento continua ao institucionalizar suas demandas como o fizeram os sanitaristas no governo Lula? A reprodução do repertório sem elementos não convencionais necessários para mobilizar e pressionar as autoridades na luta pelos recursos mostra que $o$ movimento experimentava uma posição ambígua e ameaçadora para a sua capacidade de mobilizar e de impactar na política setorial.

Os sanitaristas permaneceram no Ministério da Saúde após o primeiro mandato de Lula. Desse modo, alargaram os seus domínios de agência, aprovando 
diversas "políticas nacionais" que tornavam a sua visão da saúde norteadora e preponderante em termos de ações públicas. O Sistema Único de Saúde, alinhado com os ideais da Reforma Sanitária, ganhava com isso maior estabilidade ao ponto dos próprios atores concluírem que "Ninguém hoje questiona que o Sistema Único de Saúde, integral e universal, foi conquista da sociedade brasileira" (Diretoria Nacional do Cebes, 2012: 4). Todavia, o estabelecimento de pontos de acesso e influência e de domínios de agência não significou a desmobilização do movimento, que continuou interpretando a situação do setor em termos movimentistas identificando problemas, apontando suas causas, estabelecendo a relação entre "nós" e "eles" e propondo planos de ação. No início de 2012, o movimento retomou a não solucionada questão acerca dos recursos em uma nova campanha, intitulada "Movimento Nacional em Defesa da Saúde Pública". Os atores propõem uma nova tática via instituições que ainda não havia sido utilizada pelo movimento. Recorrem ao instrumento da Lei de Iniciativa Popular, que possibilita à sociedade civil ser propositora de lei com base em um número grande - um milhão e quatrocentos mil de assinaturas ${ }^{100}$. O movimento quer utilizar a força de voz da sociedade para legitimar e dar força à sua reivindicação que já sofreu diversas derrotas. A diretoria do Cebes anunciava, em 2012: "O instrumento e a força de mobilização e militância estão lançados. É a oportunidade e a hora de a sociedade brasileira abraçar o SUS, e dizer com clareza que sua saúde é prioridade, e que deve ser provida pelo Estado brasileiro. Vamos à luta!" (Diretoria Nacional do Cebes, 2012: 6).

${ }^{100}$ A Lei de Iniciativa Popular foi regulamentada em 1998 e prevê a apresentação de um abaixoassinado à Câmara dos Deputados, subscrito por, no mínimo, 1\% do eleitorado nacional, distribuído por, pelo menos, cinco Estados, com não menos de três décimos por cento dos eleitores de cada um deles. 


\section{Conclusão}

A questão central do trabalho aqui apresentado foi a consideração analítica das ações desenvolvidas pelo Movimento Sanitário Brasileiro nas instituições políticas como parte dos movimentos sociais, para as quais não existiam categorias nas abordagens teóricas sobre os movimentos. A questão não era apenas de classificação e sim da compreensão da atuação de um ator coletivo que compartilha uma visão de mundo, mobiliza-se, estabelece estratégias e articula ações: o Movimento Sanitário/pela Reforma Sanitária. Tratava-se de estabelecer uma conexão analítica entre o movimento social na acepção da teoria e aquilo que, ao atravessar a fronteira das instituições, começa a ser circunscrito por outras abordagens teóricas. Essa conexão se tornou visível na medida em que introduzimos ao aparato conceitual da Teoria dos Movimentos Sociais - e este trabalho não é solitário nessa tarefa - a possibilidade analítica de considerar como ação do movimento aquela que ocorria "via instituições". Mostramos que não apenas essas ações estavam em relação direta com as estratégias do movimento, isto é, com as diretrizes compartilhadas por um coletivo, mas também que os atores do movimento conseguiam atribuir a elas um caráter não convencional de modo a surpreender as autoridades e motivar os seus adeptos. Com essa conexão foi possível mostrar as transformações do movimento e do Estado, numa expressão clara de mútua constituição e também de dinâmicas próprias do movimento social.

Argumentamos, no primeiro capítulo, que a Teoria dos Movimentos Sociais, com sua ênfase no repertório de ação "fora das instituições" e com a conceituação da institucionalização restrita a protestos e organizações dos movimentos sociais, não oferece categorias adequadas para dar conta da atuação do Movimento Sanitário. Com base nisso, sugerimos a distinção no interior do conceito de "repertório de ação dos movimentos sociais" entre as ações "fora das instituições", que são privilegiadas pela literatura, e as ações "via instituições". Ao definir estas últimas como aquelas nas quais os atores operam por meio de regras institucionais, introduzíamos também um critério interno de diferenciação entre as ações convencionais e as não 
convencionais, que correspondia à exigência da teoria relacionada com a inovação como elemento importante para mobilizar os integrantes dos movimentos e aumentar a capacidade de afetar as decisões das autoridades. A inclusão das ações "via instituições" permitiu elaborar os desdobramentos analíticos adicionais em torno das categorias de "eventos de movimentos", "organizações" e "oportunidades políticas".

A reconstituição do Movimento Sanitário/pela Reforma Sanitária, em cinco períodos, ao longo de mais de 30 anos, e do seu repertório de ação permitiu mostrar que é possível falar nas ações "via instituições" sem que se abra mão da categoria de movimentos sociais. Chegamos a um conjunto de táticas empregadas pelo movimento, tais como a ocupação de cargos, a apropriação de espaços estatais, o uso de accountability horizontal e a ação nos interstícios dos setores de políticas públicas. Todavia, como elas dependem da estruturação do Estado e das instituições políticas, o achado mais importante do nosso estudo consiste em mostrar que os atores do movimento inovam ao agir "via instituições", abrindo com isso a possibilidade analítica de romper a separação entre os movimentos sociais e o Estado como polos que opera na teoria e acompanhar os atores do movimento social enquanto tais em suas incursões no Estado.

Ainda nos anos 1970, durante o regime militar, os atores do Movimento Sanitário adotaram a estratégia de caminho institucional em busca da realização do objetivo da universalização do acesso público à saúde. Uma das táticas "via instituições" utilizada era a ocupação de cargos nas agências setoriais. Seu caráter não convencional decorria do fato de que os militantes optavam por trabalhar junto ao regime político que combatiam e introduziam ações que visavam, a médio prazo, solapar o sistema de saúde em vigência. A tática era, ao mesmo tempo, um objeto de debates e polêmicas no próprio movimento e demandava mobilização. A infiltração ocorreu tanto nas principais agências setoriais quanto nas margens do sistema, nas quais a produção de serviços de saúde era apenas residual, como foi o caso dos municípios. Ou ainda, no programa interministerial que oferecia a possibilidade de preparação dos quadros profissionais para um novo padrão de serviços.

Os atores do movimento nos cargos de direção no Estado valeram-se também da tática de apropriação de espaços e atividades estatais, tanto em termos de 
mobilização quanto em termos da introdução de novos tipos de ação pública alinhada com os objetivos do movimento. A expressão extrema dessa tática foi a transformação da Conferência Nacional de Saúde, evento da burocracia estatal, em uma ampla mobilização da sociedade civil em prol da causa do movimento. O uso não convencional da Conferência dotou o projeto do movimento de uma alta carga de legitimação diante das autoridades e permitiu a criação de um ponto de acesso e influência no Estado. Os sanitaristas nos cargos de secretários municipais de saúde, ainda nos anos 1970, iniciaram a organização de eventos do setor municipal de saúde, mas conduzidos pelo movimento. Houve experiências mais discretas dessa apropriação como, por exemplo, no Acordo de Cooperação Técnica Opas-Brasil em Recursos Humanos, programa interministerial aproveitado pelos sanitaristas para por em prática a estratégia da formação do campo profissional sob égide da Reforma Sanitária nos anos 1980.

Após a aprovação na Constituição, em 1988, do Sistema Universal de Saúde, nos termos defendidos pelo movimento, e, em seguida, durante a sua implementação, a ocupação de cargos acabou sendo convencional, e só voltou a surpreender quando ocorreu em uma escala sem precedentes no primeiro governo Lula (2003-2006). Todos os cargos de direção no Ministério da Saúde foram preenchidos pelos sanitaristas, que introduziam no Estado diversas vertentes do movimento com as suas temáticas e modos de ação e mobilização. Os militantes levaram as estratégias do movimento às últimas consequências. Buscaram a institucionalização de suas demandas, adequando as instâncias do Ministério da Saúde às suas linhas de atuação, estabelecendo Políticas Nacionais em diversas áreas e criando programas nacionais. A estratégia de "formação do campo profissional" foi elevada a estatuto de diretriz geral da formação e educação para a Reforma Sanitária. Mais que isso. Os sanitaristas instrumentalizaram a ação pública de modo a fomentar a mobilização do próprio movimento. Se o movimento se tornou governo, a ação pública deste foi carregada de conteúdo e forma movimentistas.

Os diagnósticos e os prognósticos construídos pelo movimento apontaram que os atores não enxergam o Estado como bloco monolítico e distinguem nele fontes específicas de ameaça para sua causa. Nesse sentido também têm recorrido à tática de accountability horizontal, ao acionar partes do Estado para exercer a pressão sobre 
as outras. Fizeram-no em 1993, ao entrarem com o requerimento de ação no Ministério Público Federal contra o Poder Executivo. Outra forma coletiva de exercer pressão, utilizando um poder do Estado contra o outro, têm sido os Simpósios sobre a Política Nacional de Saúde, organizados no Congresso Nacional, nos quais o movimento, em aliança com parlamentares, sinaliza ao Poder Executivo sua posição, pautada na força de mobilização, em momentos politicamente nevrálgicos. $\mathrm{O}$ Movimento pela Reforma Sanitária recorreu ainda às instituições participativas para ganhar a capacidade de negociação com as instâncias equivalentes em outro setor de política pública. Vimos esse uso do Conselho Nacional de Saúde quando este exigiu do Conselho Nacional de Educação a instalação de audiências públicas para influenciar a formulação de diretrizes curriculares dos cursos superiores na área de saúde.

Essa última ação fazia parte da estratégia de "formação do campo profissional", que ganhou um caráter não convencional, ao tentar subordinar a formação dos quadros profissionais ao setor de saúde. Com isso, o movimento desafiava o domínio de agência do setor educacional e, praticamente até o final dos anos 1990, os militantes adotaram a tática de atuar nos interstícios dos setores de políticas públicas conjugada àquela de ocupação dos poucos cargos disponíveis para tanto. Procuravam brechas institucionais para introduzir a formação dos profissionais, capacitações, produção de pesquisas, entre outras ações alinhadas às necessidades da Reforma Sanitária, sem que essas experiências conseguissem alcançar uma grande escala. No entanto, serviram de modelos nos momentos em que apareceram as oportunidades aproveitadas pelo movimento para expandi-las, como vimos no caso da Rede Unida ou do Projeto Larga Escala.

A formação para a Reforma Sanitária não cumpre só o objetivo de preparar os profissionais para atuarem no sistema público de saúde; por meio dela o movimento almeja aumentar as fileiras dos defensores do SUS e, portanto, potenciais integrantes das mobilizações do movimento. A reformulação e ampliação da estratégia ficam claras quando os sanitaristas chegam ao Ministério da Saúde, no governo Lula, e transformam a formação em uma diretriz básica de todas as atividades desenvolvidas no SUS. 
A estratégia do caminho institucional levou os atores do movimento a ativar também ações "fora das instituições" do tipo convencional como lobby, negociação com o Poder Executivo e protestos pacíficos. A pressão no Congresso e junto aos parlamentares por meio de reuniões, visitas, entregas de abaixo-assinados nada teria de diferencial, não fosse a novidade da forma organizacional que o movimento assumia. O movimento optou pela formação de um novo coletivo, aberto e com pouca formalização, o qual permitia, facilmente, ampliar as fileiras do movimento e demonstrar sua força numérica e de ampla representação, como ocorreu na Plenária Nacional de Saúde, durante a Constituinte, ou na Plenária Nacional dos Conselhos de Saúde, nos anos 1990. O formato organizacional das Plenárias, que foi adotado por outros atores do movimento, demandou um enquadramento analítico diferente das organizações, não mais como recurso necessário para a mobilização, mas como ação política, conforme sugere Clemens (1993).

Entre as formas adotadas pelos atores do movimento, destacamos aqui um tipo particular do "ator-evento", que, como categoria, denomina aqueles formatos organizacionais do movimento que se consubstanciam no momento em que os seus participantes se reúnem. Caracteriza-se pela não formalização das regras de pertencimento ou filiação, o que tende a ampliar o leque de seus integrantes de acordo com as necessidades do processo político. Esse ator é sempre atrelado à organização de um evento no qual se consubstancia, o que lhe permite adquirir o caráter de mobilização. Além das Plenárias que atuavam no Congresso, a Rede Unida adquiriu esse mesmo formato para mobilizar e encaminhar as ações em torno da estratégia da formação do campo profissional. Na vertente de Educação Popular e Saúde, essa forma de mobilizar os atores e configurar o novo coletivo foi adotada na Articulação Nacional de Movimentos e Práticas de Educação Popular e Saúde. Os atores-eventos são a faceta simultânea da mobilização e organização do movimento social. Emergem com base nos recursos dos atores ou instituições já instituídos ao mesmo tempo em que trazem elementos de novidade que despertam a motivação para a ação nos seus integrantes e podem surpreender as autoridades pela sua força e capacidade de mobilização.

Argumentávamos, no primeiro capítulo, que é possível observar analiticamente o movimento por meio de "eventos" (Oliver; Myers, 2003) no lugar 
de "ciclos de protestos". O "ator-evento" constituiu uma das evidências desse potencial. A adoção de categoria de "evento" como uma faceta coletiva do movimento revela espaços, não levados necessariamente em consideração pela literatura, que mobilizam integrantes, constituem-se como palcos para o estabelecimento de estratégias, articulações e táticas, bem como conformam os momentos de produção e reprodução da identidade coletiva. A ausência de protestos, o seu número reduzido ou a sua diminuição não significa necessariamente desmobilização do movimento ou um estado de latência. A observação dos eventos do Movimento Sanitário/pela Reforma Sanitária permitiu destacar três pontos no sentido de valorizar os "eventos" como instância do movimento social. Em primeiro lugar, seu crescente caráter híbrido que conecta diversos atores societais e estatais em torno das temáticas e áreas comuns ligados, apesar da especificidade, ao projeto da Reforma Sanitária. Se as temáticas se diversificam, na medida em que o objetivo maior do movimento foi alcançado com a aprovação do SUS na Constituição, os eventos tendem a se abrir para uma diversidade de participantes e, entre eles, a universidade, o setor público de saúde, os seus usuários e prestadores de serviços, em vez de optar pela especialização, seja acadêmica ou profissional. Em segundo lugar, frequentemente, esses encontros, ao reunirem milhares de participantes, adquirem peso em termos de mobilização para se posicionar politicamente por meio de documentos amplamente publicizados. Em terceiro lugar, por trás da fachada de seminários, congressos e simpósios, esses eventos regulares e os conjunturais oferecem a possibilidade para coordenar as ações coletivas, articular as táticas, ajustar as estratégias. O Congresso de Saúde Coletiva, o Abrascão, é uma expressão disso, mas essa é a tônica de grande parte dos eventos registrados ao longos dos trinta anos.

Não obstante a efervescência de eventos e organizações, é possível observar na trajetória do movimento a tendência identificada na teoria de sua rotinização ou burocratização. As formas envelhecem, perdem a capacidade de mobilizar e influenciar as autoridades (Tilly, 2006). Tornam-se partes da paisagem política como cristalizações institucionais ou deixam de existir. Os atores do movimento, todavia, o percebem e reagem a essa tendência ao criarem formas novas nas quais, ao lado dos elementos do repertório disponível, incluem algum caráter de novidade. O 
movimento social, mais do que atores institucionalizados, como os partidos ou os sindicatos, possui esse potencial e possibilidade de se reinventar em termos de repertório de ação, de suas organizações e eventos.

O movimento social que se utiliza das ações "via instituições", possibilitadas pelo acesso a recursos ou posições de seus membros, atravessa constantemente a fronteira analítica estabelecida pela teoria entre os movimentos sociais e o Estado como atores antagônicos ou cuja interpenetração tende a anular o movimento social. Não queremos negar em absoluto esse risco, todavia, o caso do Movimento Sanitário/pela Reforma Sanitária mostra que o movimento pode produzir no Estado as oportunidades para a sua própria continuidade, não em termos de sobrevivência de um ator ou evento, mas da produção e reprodução de sua identidade coletiva e da capacidade de mobilizar novos adeptos. Ao institucionalizar essas oportunidades, como o fez nos anos 2000, o Movimento pela Reforma Sanitária apostou que delas poderiam emergir novos atores e novas mobilizações.

Reconstruir a trajetória do Movimento Sanitário/pela Reforma Sanitária foi um privilégio. Em primeiro lugar, porque significou "conviver" ao longo de quatros anos com as pessoas que, obstinada e incansavelmente, lutavam e ainda lutam pelo acesso universal à saúde no Brasil, fazendo desse projeto, nunca plenamente realizado, o sentido de suas vidas. É da compreensão construída coletivamente sobre a incompletude do projeto da Reforma Sanitária que surgem as estratégias, táticas e formas organizacionais que - e essa é a segunda face do privilégio - surpreendem e encantam pela sagacidade, perspicácia e inovação. Assim, manifesto nessas últimas linhas do trabalho, ao qual dediquei quatro anos, a minha profunda admiração pelos sanitaristas e pela sua atuação que não se contenta com o aqui e agora, mas se norteia pelo objetivo maior a ser alcançado: a saúde para todos nós. 


\section{BIBLIOGRAFIA}

ABERS, Rebecca; SERAFIM, Lizandra; TATAGIBA, Luciana. (2011) “A participação na era Lula: repertórios de interação em um Estado heterogêneo". Trabalho apresentado no GT04 Controles Democráticos e Legitimidade. $35^{\circ}$ ENCONTRO ANUAL da ANPOCS. Caxambu, Minas Gerais.

ABRASCO. (1983) “V Seminário de Avaliação dos cursos de Saúde Publica da ENSP, 1980-1981." Ensino da Saúde, Medicina Preventiva e Social no Brasil, 2.

(1994) "Congresso da Abrasco". Boletim Abrasco, Rio de Janeiro, ano XII, n.

53, ago-set.

ABRASCO, CEBES, SESB/PR. (1985) "Relatório final da Reunião de Trabalho sobre as Ações Integradas de Saúde". Saúde em Debate, Rio de Janeiro, n.17.

ALONSO, Ângela. (2009) "As teorias dos movimentos sociais: um balanço do debate." Lua Nova, São Paulo, 76: 49-86.

; COSTA, Valeriano; MACIEL, Debora. (2007) “Identidade e estratégia na formação do movimento brasileiro". Novos Estudos, 79: 151-167, São Paulo.

ALVAREZ, Sônia; DAGNINO, Evelina; ESCOBAR, Arturo. (2000) "Introdução: o cultural e o político nos movimentos sociais latino-americanos". In: ALVAREZ, Sônia; DAGNINO, Evelina; ESCOBAR, Arturo. Cultura e política nos movimentos sociais latino-americanos. Novas leituras. Belo Horizonte, Editora UFMG.

AMENTA, Edwin. (2006) When Movements Matter: The Townsend Plan and the Rise of Social Security. Princeton, New York, Princeton University Press.

ARANTES, Rogério Bastos. (2002) Ministério Público e Política no Brasil. São Paulo, Sumaré/Educ.

ARATO, Andrew; COHEN, Jean L. (2000) "Los movimientos sociales y la sociedad civil". In: ARATO, Andrew; COHEN, Jean L. Sociedade civil y teoria política. México, Fondo de Cultura Econômica.

ARAUJO, Maria Paula Nascimento. (2007) "Lutas democráticas contra a ditadura". In: FERREIRA, Jorge; REIS, Daniel Aarão (Orgs.). As esquerdas no Brasil: Revolução e democracia (1964...). Rio de Janeiro, Civilização Brasileira, v. 3, p. 321-354.

AROUCA, Sérgio. (1988) "Implementação da Reforma Sanitária através do SUDS". Saúde em Debate, Rio de Janeiro n. 22.

(1988) "Saúde na constituinte - A defesa da Emenda Popular". Saúde em

Debate, Rio de Janeiro, n. 20, p. 39-46. 
(2003) “Deu certo". Saúde para Debate, Rio de Janeiro, n. 28.

ARRETCHE, Marta. (2001) "Federalismo e Relações Intergovernamentais no Brasil: A Reforma dos Programas Sociais". Dados - Revista de Ciências Sociais, Rio de Janeiro, v. 45, n. 3, p. 431-457.

(2003). “Financiamento federal e gestão local de políticas sociais: o difícil equilíbrio entre regulação, responsabilidade e autonomia". Ciência e Saúde Coletiva, Rio de Janeiro, 8 (2). Disponível em: <http://www.scielo.br/scielo.php?script=sci_arttext\&pid=S1413-

$81232003000200002 \& \operatorname{lng}=$ pt\&nrm=iso>, acesso em: 4 set. 2006.

. (2005) "A política da política de Saúde no Brasil". In: LIMA, Nísia Trinidade et al. (Orgs.) Saúde e democracia: história e perspectivas do SUS. Rio de Janeiro, Editora Fiocruz.

AVRITZER, Leonardo. (1997) “Um desenho institucional para o novo associativismo". Lua Nova, São Paulo, n. 39, CEDEC.

(2008) "Instituições participativas e desenho institucional: algumas considerações sobre a variação da participação no Brasil democrático". Opinião Pública, Campinas, 14 (1).

BARBIERI, Fernanda Bersanetti. (2006) A Rede UNIDA e o Movimento de Mudança na Formação dos Profissionais de Saúde. Dissertação de Mestrado (Saúde Coletiva), Universidade Estadual de Londrina, Londrina.

BARROS, E.; PORTO, S. (2002) "Health Care in Brazil: equity as challenge". Trabalho apresentado em, Global Development Network. Washington DC, Estados Unidos.

BASSINELLO, Greicelene Aparecida Hespanhol; BAGNATO, Maria Helena Salgado. (2009) "Os primórdios do Projeto Larga Escala: tempo de rememorar". Revista Brasileira de Enfermagem, Brasília, 62 (4). Disponível em http:/ / www.scielo.br/scielo.php?script=sci_arttext\&pid=S0034-71672009000400022. Acesso em 28 de julho de 2012.

BELISÁRIO, Soraya Almeida. (2002) Associativismo em saúde coletiva: um estudo da Associação Brasileira de Saúde Coletiva-Abrasco. Tese de doutorado ( Saúde Coletiva), Universidade Estadual de Campinas, Campinas.

BENFORD, Robert, D.; SNOW, David, A. (2000) “Framing Processes and Social Movements: an overview and assessment". Annual Review of Sociology, Palo Alto, California, USA, v. 26, p. 611-39.

BERTONE, Arnaldo Agenor. (2002) "As idéias e as práticas: a construção do SUS". Dissertação de Mestrado (Medicina Social), UERJ, Instituto de Medicina Social, Rio de Janeiro. 
BOSCHI, Renato Raul. (1987) A arte da associação: política de base e democracia no Brasil. Rio de Janeiro, IUPERJ.

; VALLADARES, Lícia do Prado. (1983) "Problemas teóricos na análise de movimentos sociais: comunidade, ação coletiva e o papel do Estado". Espaço e Debates: Revista de Estudos Regionais e Urbanos, São Paulo, Annablume editora, n. 8 .

BRANDÃO, Lucas Coelho. (2011) Os movimentos sociais e a Assembleia Nacional Constituinte: entre a politica institucional e a participação popular. Dissertação de Mestrado (Programa de Sociologia). Universidade de São Paulo, Faculdade de Filosofia, Letras e Ciências Humanas, São Paulo.

BRASIL/MEC. (1997) Ministério da educação e do desporto secretaria de educação superior. Brasília, Edital No 4 / 97.

BRASIL. Ministério da Saúde. B823. (2007) "Projeto Economia da Saúde - PES: Reforçando Sistemas de Saúde para reduzir desigualdades (2002-2005)". PEROCCO, Angela Márcia Loureiro; RAGGIO, Armando Martinho Bardou; VIANNA, Solon Magalhães (orgs). Relatório de Atividades. Brasília: Ministério da Saúde.

BRASIL. Ministério da Saúde. CNS. (2006) Plenárias Nacionais de Conselhos de Saúde. Resgate Histórico do Controle Social no SUS. Ministério da Saúde, Conselho Nacional de Saúde, Brasília, Editora do Ministério da Saúde.

BRASIL/MS/CNS - Brasil/Ministério da Saúde/Conselho Nacional de Saúde. (2007) "Carta Aberta ao Controle Social e a Todas as Cidadãs e os Cidadãos Brasileiros. XIV Plenária Nacional de Conselhos de Saúde". In: Plenárias nacionais de conselhos de saúde: relatórios finais XIII e XIV. Brasília, Editora do Ministério da Saúde. Disponível em: <http://conselho.saude.gov.br/biblioteca/Relatorios/plenarias_xiii_xiv.pdf. Acesso em 5 de maio de 2011.

BRASIL. Lei No 8.080, de 19 de setembro de 1990. Dispõe sobre as condições para a promoção, proteção e recuperação da saúde, a organização e o funcionamento dos serviços correspondentes e dá outras providências. Presidência da República, Casa Civil, Subchefia para Assuntos Jurídicos. Disponível em <http://www.planalto.gov.br/ccivil_03/leis/L8080.htm.> Acesso em 23 de março de 2010.

BRASIL. (1988) Constituição da República Federativa do Brasil. Brasília: DF, Senado.

BRASIL. Lei No 6.439, de 1 de setembro de 1977. Instituiu o Sistema Nacional de Previdência e Assistência Social. Presidência da República, Casa Civil, Subchefia para Assuntos Jurídicos. Disponível em http://www.planalto.gov.br/ccivil_03/leis/L6439.htm . Acesso em 23 de março de 2010. 
BRASIL. Mensagem de veto ${ }^{\circ} 68$ do Presidente da República, de 20 de setembro de 1990.

BRASIL/MS/SEGP. Ministério da Saúde. Secretaria de Gestão Estratégica e Participativa. (2006) A Construção do SUS. Histórias da Reforma Sanitária e do Processo Participativo. Brasília, Editora do Ministério da Saúde.

BRASIL/MS - Brasil. Ministério da Saúde. (2007) "Projeto Economia da Saúde-PES: Reforçando Sistemas de Saúde para reduzir desigualdades." In: PEROCCO, Angela Márcia Loureiro, RAGGIO; BARDOU; Armando Martinho; VIANNA; Solon Magalhães. (Orgs.) Relatório de Atividades (2002-2005). Brasília, Editora do Ministério da Saúde.

BRASIL/MS/CNS - Brasil. Ministério da Saúde. Conselho Nacional de Saúde (2006) Plenárias nacionais de conselhos de saúde: resgate histórico do controle social no SUS. Brasília, Editora do Ministério da Saúde.

BRASIL/MS/DCT/SCTIE - Brasil. Ministério da Saúde. Departamento de Ciência e Tecnologia. Secretaria de Ciência, Tecnologia e Insumos Estratégicos. (2008) "Pesquisa em saúde no Brasil". Revista Saúde Pública, n. 42 (4), p. 773-775. Disponível em: <http://dx.doi.org/10.1590/S0034-89102008000400027>. Acesso em 11 de novembro de 2011.

BRASIL/MS/SGEP - Brasil. Ministério da Saúde. Secretaria de Gestão Estratégica e Participativa (2009). Política Nacional de Gestão Estratégica e Participativa no SUS - ParticipaSUS. Brasília, Editora do Ministério da Saúde.

BRESSER-PEREIRA, Luis C. (1997). "Estratégia e estrutura para um novo Estado". Revista de Economia Política, São Paulo, 17(3), p. 24-38.

BUSS, Paulo Marchiori. (1982) “A experiência do Programa de Apoio às Residências em Medicina Social, Medicina Preventiva e Saúde Pública (PAR-MS/MP/SP)". In: ABRASCO-Ensino da Saúde Pública, Medicina Preventiva e Social no Brasil. Rio de Janeiro, UFRJ, OPAS, Abrasco.

(1988) “Fala por ocasião da concessão do título de Professor Honoris Causa desta Escola ao Dr. Hésio de Albuquerque Cordeiro, Medicina social no Brasil esboço do perfil de um pioneiro". Caderno Saúde Pública, 4 (3), Rio de Janeiro.

CAMPOS, Francisco Eduardo; GIRARDI, Sábado Nicolau. (1984) “Caracterização dos programas de residência preventiva e social no Brasil". In: ABRASCO - Ensino da Saúde Pública, Medicina Preventiva e Social no Brasil. UFRJ, OPAS, Abrasco, Rio de Janeiro.

CAMPOS, Gastão Wagner de Sousa. (1988) “A reforma sanitária necessária”. In: BERLINGUER, G; TEIXEIRA, S.F.; CAMPOS, Gastão.W.S.. Reforma Sanitária: Itália e Brasil. São Paulo, Hucitec. (1991) A Saúde Pública e a defesa da vida. São Paulo, Editora Hucitec. 
CAPISTRANO FILHO, David; PIMENTA, Aparecida Linhares. (1988) Saúde para todos: um desafio ao munícipio. Hucitec, São Paulo.

CARDOSO, Ruth Correa Leite. (1984) "Movimentos sociais urbanos: balanço crítico". In: SORJ, Bernardo; ALMEIDA, Maria Hermínia Tavares (Orgs.), Sociedade e Política no Brasil Pós-64. São Paulo, Brasiliense.

(1994) "A trajetória dos movimentos sociais". In: DAGNINO, Evelina (Org.) Anos 90 - política e sociedade no Brasil. São Paulo, Brasiliense.

CARLOS, Euzeneia. (2012) Movimentos Sociais e instituições participativas: efeitos organizacionais, relacionais e discursivos. Tese de doutorado (Programa de Ciência Política). Universidade de São Paulo. Faculdade de Filosofia, Letras e Ciências Humanas, São Paulo.

CARTA DA 9a CONFERÊNCIA NACIONAL DE SAÚDE. (1992) “Carta da 9a Conferência Nacional de Saúde à sociedade brasileira: em defesa da vida e da ética: fora Collor". In: Relatório da 9a Conferência Nacional de Saúde. Disponível em: <http://conselho.saude.gov.br/biblioteca/Relatorios/relatorio_9.pdf> Acesso em 21 de março de 2009.

CARTA DA FEDERAÇÃO BRASILEIRA DE HOSPITAIS - FBH. (1984). “Carta da Federação Brasileira de Hospitais, assinada por Sília Nascimento Andrade de 14 de dezembro de 1984 de Salvador". Saúde em Debate, Rio de Janeiro, CEBES, n. 17, jul., p.41.

CARTA DA 10a CONFERÊNCIA NACIONAL DE SAÚDE. (1996) “Carta da 10a Conferência Nacional de Saúde". In: Relatório da 10a Conferência Nacional de Saúde.

$<$ http://conselho.saude.gov.br/biblioteca/Relatorios/relatorio_10.pdf >. Acesso em 15 de setembro de 2011.

CARTA DE PORTO ALEGRE E DE BELO HORIZONTE. (1992) "Carta de Porto Alegre e de Belo Horizonte - A Saúde como Direito à Vida". Boletim Abrasco, Rio de Janeiro, n. 46 abr/jun.

CARTA DE BELO HORIZONTE. (2005) “Carta de Belo Horizonte do 6 Congresso Nacional da Rede Unida". Disponível em: $</ /$ www.fiocruz.br/icict/media/carta_redeunida.pdf $>$. Acesso em 23 de março de 2012.

CARTA DE BRASÍlIA. (1992) "Carta de Brasília do 8a Encontro Nacional de Secretários Municipais de Saúde Brasília". Disponível em : <http://www.conasems.org.br/files/15anosConasems.pdf>. Acesso em 12 de abril de 2011.

CARTA DE BRASÍLIA. (1997) “Carta de Brasília do 13a Encontro Nacional de Secretários Municipais de Saúde". Disponível em: 
< http://www.conasems.org.br/files/15anosConasems.pdf> .Acesso 12 de abril de 2011.

CARTA DE BRASÍLIA. (2005) "Carta de Brasília do $8^{\circ}$ Simpósio sobre Política Nacional de Saúde". Disponível em: <http://www.ensp.fiocruz.br/radis/revistaradis $/ 37 /$ pos_tudo/ $>$.

CARTA DE CURITIBA. (1993) "Carta de Curitiba do 10a Encontro Nacional de Secretários Municipais de Saúde Curitiba". Disponível em: <http://www.conasems.org.br/files/15anosConasems.pdf>. Acesso em 12 de abril de 2011.

CARTA DE FORTALEZA. (1990) "Carta de Fortaleza do 7a Encontro Nacional de Secretários Municipais de Saúde e $8^{a}$ Encontro Municipal do Setor de Saúde". Disponível em: <http://www.conasems.org.br/files/15anosConasems.pdf>. Acesso em 12 de abril de 2011.

CARTA DE MONTES CLAROS. (1985) “Carta de Montes Claros do 6a Encontro Municipal do Setor de Saúde e do $3^{a}$ Encontro Nacional de Secretários Municipais de Saúde". Saúde em Debate, Rio de Janeiro, n.17, CEBES.

CARTA DE PORTO ALEGRE (1989) “Carta de Porto Alegre do 6a Encontro Nacional de Secretários Municipais de Saúde e 7a Encontro Municipal do Setor de Saúde". Disponível em: <http://www.conasems.org.br/files/15anosConasems.pdf>. Acesso em 12 de abril de 2011.

CARTA DOS PROFISSIONAIS DE SAÚDE. (1977). Saúde em Debate, 5, CEBES, Rio de Janeiro, out./nov./dez.

CARVALHO, Eneuton Dornalles Pessoa. (2011) “O aparelho administrativo brasileiro: sua gestão e seus servidores - de 1930 aos dias atuais". In: CARDOSO JR. José Celso (org.) Burocracia e ocupação no setor público brasileiro. Rio de Janeiro, Ipea, v. 5.

CARVALHO, Gilson (s/d) "Projeto de lei federal para criação da CIT-CIB", In: Rede Nacional de Pessoas com Diabete. Disponível em: <http://www.rnpd.org.br/download/pdf/2009gc_plei.pdf>. Acesso em 26 de abril de 2011.

(2001) "A inconstitucional administração pós-constitucional do SUS através de normas operacionais". Ciência e Saúde Coletiva, Rio de Janeiro, n. 6 (2). Disponível em: <http://dx.doi.org/10.1590/S1413-81232001000200012>. Acesso em 30 de março de 2011.

\footnotetext{
(2007) Participação da Comunidade na Saúde: dinheiro para a saúde: o DiaD- 5/12/2007. Disponível em: (<http://www.idisa.org.br/img/File/EC_29MAISDIN.SAUDE.pdf>. Acesso em 21 de fevereiro de 2012.
} 
CASTRO, Janete Lima de Castro. (2008) Protagonismo Silencioso: A presença da OPAS na formação de recursos humanos no Brasil. Observatório RH-NESC da UFRN; Ministério de Saúde; OPAS/OMS. Natal-RN.

CEBES - Centro Brasileiro de Estudos de Saúde. (1980) “Questão democrática na área de saúde", (documento apresentado pelo CEBES no $1^{\text {a }}$ Simpósio sobre Política Nacional de Saúde de Novembro de 1979). Saúde em Debate, Rio de Janeiro, n.9.

(1985) "Assistência à saúde numa sociedade democrática (documento apresentado pelo CEBES no 5a Simpósio sobre a Política Nacional de Saúde de novembro de 1984)". Saúde em Debate, Rio de Janeiro n.17, CEBES.

. (1985) “Notas do CEBES”. Saúde em Debate, Rio de Janeiro, n.17, jul, CEBES.

CECÍLIO, Luís Carlos de Oliveira. (1994) “Inventando a mudança em uma região de saúde: reconstituição e análise da experiência do departamento regional de saúde de Campinas (DRS-5) - 1983-1987". In: CECÍlIO, Luis Carlos de Oliveira (org.). Inventando a mudança na saúde. São Paulo, Hucitec.

CECCIM, Ricardo Burg. (2008) "A emergência da educação e ensino da saúde: intersecções e intersetorialidades”. Revista Ciência \& Saúde, Porto Alegre, 1(1).

CLEMENS, Elisabeth. (1993) “Organizational Repertoires and Institutional Change: Women's Groups and the Transformation of U.S Politics, 1890-1920". American Journal of Sociology, Chicago, USA, 98 (4).

(2006) "Organizational form as frame: collective identity and political strategy in the American labor movement, 1880-1920". In: McADAM, Doug; McCARTHY, D. John; ZALD, N. Mayer. (orgs.) Comparative Perspectives on Social Movements. Political Opportunities, Mobilizing Structure, and Cultural Framings. Cambridge, Cambridge University Press.

; MINKOFF, Debra C. (2004) "Beyond the Iron Law: Rethinking the Place of Organizations in Social Movements Research". In: SNOW, David A.; SOULE, Sarah A.; KRIESI, Hanspeter. The Blackwell Companion to Social Movements. USA, UK, Australia, Blackwell Publishing.

COELHO, Vera Schattan P. (2007) “A Democratização dos conselhos de Saúde: o paradoxo de atrair não aliados". Novos Estudos, São Paulo, n. 78, p.77-92, Cebrap.

COHEN, Joshua. e ROGERS, Joel. (1995) "Associations and Democracy". In: WRIGHT, E. O. (ed.) The Real Utopias Project, London, New York, 1, Verso.

COHN, Amélia. (1989) "Caminhos da Reforma Sanitária". Lua Nova, São Paulo, n.19.

ELIAS, Paulo Eduardo Mangeon. (Orgs.) (2005) Descentralização e saúde no estado de São Paulo. As articulações entre as esferas do governo. São Paulo, CEDEC. 
COMISSÃO - Comissão da Saúde da Câmara dos Deputados. (1985) "Proposta Política para um programa de saúde (Relatório final e proposições aprovadas pelo $5^{\mathrm{a}}$ Simpósio sobre políticas nacional de saúde, realizado nos dias 28 a 29 de novembro de 1984)". Saúde em Debate, Rio de Janeiro, n.17, p.33-36, CEBES.

COMISSÃO DE SAÚDE da Câmara dos Deputados. (1985) "Proposta Política para um Programa de Saúde". Saúde em Debate, Rio de Janeiro, n.17, p. 33-36, jul. CEBES.

CNRS - Comissão Nacional da Reforma Sanitária. (1986) "Proposta para o componente Saúde da nova Constituição Brasileira" e "Proposta de conteúdo para uma nova Lei do Sistema Nacional de Saúde". Rio de Janeiro

CONASEMS - Conselho Nacional de Secretarias Municipais de Saúde (2003) CONASEMS: 15 ANOS! Disponível em: $<$ http://bvsms.saude.gov.br/bvs/publicacoes/historia_conasems.pdf >. Acesso em 17 de setembro de 2012.

(2007) Movimento sanitário brasileiro na década de 1970: a participação das universidades e dos municípios. Brasília, Conasems.

(2008) CONASEMS: 20 anos. Disponível em: <http://www.saude.mt.gov.br/adminpublicacao/arquivo/CONASEMS_Livro_20_ anos.pdf $>$, Acesso em 17 de setembro de 2012.

CONASS - Conselho Nacional de Secretários de Saúde (1985) “A questão da saúde no Brasil e diretrizes de um programa para um governo democrático" (documento aprovado durante a $18^{\text {a }}$ reunião do Conass de Belo Horizonte, de 15 a 17 de outubro de 1984). Saúde em Debate, Rio de Janeiro, n.17, p. 21-22. CEBES.

(2003) -- INFORMATIVO SEMANAL n. 02/2003. Disponível em: $<$ www.conass.org.br>. Acesso em outubro de 2011.

(2007) CONASS - 25 anos. Disponível em <http://189.28.128.100/dab/docs/publicacoes/conass_progestores/conass_25\%20a nos.pdf $>$, Acesso em 17 de setembro de 2012.

CORDEIRO, Hésio. (1991). Sistema Único de Saúde. Rio de Janeiro: Ayuri Editorial.

(2001). "Descentralização, universalidade e eqüidade nas reformas da saúde". Ciência e Saúde Coletiva, Rio de Janeiro, 6 (2). Disponível em: <http://www.scielo.br/scielo.php?script=sci_arttext\&pid=S1413-

$81232001000200004 \& \operatorname{lng}=$ pt\&nrm=iso $>$, acesso em 05 de janeiro de 2007. Acesso em novembro de 2011.

(2004) "O Instituto de Medicina Social e a Luta pela reforma Sanitária: contribuição à história do SUS." Physis: Revista Saúde Coletiva, Rio de Janeiro, 12 (2). v.14, n.2, July $2004 . \quad$ Available from: $<$ http://www.scielo.br/scielo.php?script=sci_arttext\&pid=S0103- 
$73312004000200009 \& \operatorname{lng}=$ en\&nrm $=$ iso. $>$

access on 23 Oct. 2012. http://dx.doi.org/10.1590/S0103-73312004000200009.

. (1991) Sistema Único de Saúde. Rio de Janeiro, Ayuri Editorial.

CORDONI JR., Luiz; ALMEIDA, Marcio José. (1980) “Um passo adiante?!” Saúde em Debate, Rio de Janeiro, n. 10, CEBES.

; MARTINS, Vera Lúcia. ( 1989) “Uma visão dos Núcleos de Estudos em Saúde Coletiva". Revista Saúde em Debate, Londrina, n.21, p.57-59.

CÔRTES, S. M. V; et al. (2009) "Conselho Nacional de Saúde: histórico, papel institucional e atores estatais e societais." In: CÔRTES, Soraya Vargas. (Org.). Participação e Saúde no Brasil, Rio de Janeiro, n.1, Fiocruz.

; SILVA, Marcelo Kunrath. (2010) "Sociedade civil, instituições e atores estatais: interdependências e condicionantes da atuação de atores sociais em fóruns participativos". Estudos Sociológicos, São Paulo, 15 (29),UNESP.

COSEMS-SP (2008). 20 anos SUS e COSEMS-SP. Da Constituinte 88 ao Pacto pela Saúde. São Paulo, Cosems-SP.

COSTA, Nilson do Rosário (1992) “Ciências Sociais e saúde: considerações sobre o nascimento do campo da saúde coletiva no Brasil". Saúde em Debate, Rio de Janeiro, (36), CEBES.

COSTA, Sergio. (1997) "Movimentos sociais, democratização e a construção de esferas públicas locais". Revista Brasileira de Ciências Sociais, São Paulo, 12 (35), ANPOCS.

COUTO, Cláudio Gonçalves; ARANTES, Rogério Bastos. (2006) "Constituição, governo e democracia no Brasil". Revista Brasileira de Ciências Sociais, São Paulo, 21 (61), ANPOCS.

D'ARAUJO, Maria Celina; LAMEIRÃO, Camila. (2011) “Dirigentes públicos federais de alto escalão no governo Lula". In: CARDOSO JR, José Celso. (Org.) Burocracia e ocupação no setor público brasileiro, Rio de Janeiro, Ipea.

; FARIAS, Ignez Cordeiro de; HIPPOLITO, Lucia. (Orgs.) (2004). IPEA - 40 anos apontando caminhos. Brasília, Depoimentos ao CPDOC, Disponível em: $<$ http://www.ipea.gov.br/sites/000/2/livros/ipea_40_anos/arquivo_completo.pdf >. Acesso em 20 de janeiro de 2012.

DAB - Departamento de Atenção Básica. (2007) “Atenção básica e a saúde da família". Disponível em: <http://dtr2004.saude.gov.br/dab/abnumeros.php\#historico. Acesso em 27 setembro de 2007. 
DAGNINO, Evelina. (2001) "Os movimentos sociais e a construção da democracia no Brasil: tendências recentes". Journal of Iberian and Latin American Studies, Melborne, Austrália, 7(1).

(2002) "Sociedade civil, espaços públicos e a construção democrática no Brasil. Limites e possibilidades". In: Sociedade civil e espaços públicos no Brasil. São Paulo, Paz e Terra.

(2004) "Sociedade civil, participação e cidadania: de que estamos falando?" In: MATO, Daniel.(ed.) Políticas de ciudadanía y sociedad civil en tiempos de globalización. Caracas: FACES, Universidad Central de Venezuela.

DÂMASO, Romualdo. (1989) "Saber e práxis na reforma sanitária: avaliação da prática científica no movimento sanitário". In: FLEURY, Sonia (Org.) Reforma sanitária: em busca de uma teoria. São Paulo, Cortez Editora.

DELLA PORTA, Donatela; DIANI, Mario. (2008) “The Study of Social Movements: recurring questions, (Partially) Changing Answers". In: DELLA PORTA, Donatela; DIANI, Mario. Social Movements: an Introduction. Oxford, UK, Blackwell Publishing.

DIANI, Mario. (1992) “The concept of social movement”. The Sociological Review, 40 (1).

DIAS, José Luciano de Mattos. (2002) FINEP: 30 anos de projetos para o Brasil. Rio de Janeiro: Ed. Fundação Getúlio Vargas.

DIRETORIA NACIONAL DO CEBES (2012) “É hora de a sociedade brasileira abraçar o SUS". Divulgação em Saúde para Debate, Rio de Janeiro, n. 48, ABRASCO.

DOIMO, Ana Maria; RODRIGUES, Marta M. Assumpção. (2003) “A formulação da nova política no Brasil em tempos de democratização: entre uma conduta estatista e uma concepção societal de atuação política". Política \& Sociedade, Florianópolis, Santa Catarina, n. 3, UFSC.

DOWBOR, Ladislau. (2010) “Brasil: um outro patamar". In: CARDOSO JR., José Celso; SANTOS, José Carlos dos; ALENCAR, Joana. Diálogos para o Desenvolvimento : a experiência do Conselho de Desenvolvimento Econômico e Social sob o governo Lula, Brasília, n. 2, Ipea, CDES.

DOWBOR, Monika. (2008) “Origins of Successful Health Sector Reform: Public Health Professionals and Institutional Opportunities in Brazil". Institute of Development Studies Bulletin, Brighton, UK, n.38 (6) DRC.

DRAIBE, Sonia. (1994). "As políticas sociais do regime militar brasileiro: 1964-84". In: SOARES, Gláucio D.; D’ARAÚJO, Celina. 21 Anos de Regime Militar - Balanços e Perspectivas. Rio de Janeiro, FGV. 
DRYZEK, Jonh S.; DOWNES, David; HUNOLD, Christian; SCHOLOSBERG, David; HERNES, Hans-Kristian. (2003) Green States and Social Movements: Environmentalism in the United States, United Kingdom, Germany, and Norway: Environmentalism in the United States, United Kingdom, Germany, and Norway. Oxford, UK. Oxford University Press.

ELIAS, Paulo Eduardo Mangeon. (1987) Residência Médica no Brasil: Institucionalização da ambivalência. Dissertação de mestrado. ( Medicina Preventiva da USP). Departamento de Medicina Preventiva da Faculdade de Medicina da USP. São Paulo.

EPSTEIN, Barbara. (2009) "The decline of the women's movement". In: JASPER, James M.; GOODWIN, Jeff. The Social Movements Reader. USA, UK, WileyBlackwell.

ESCOREL, Sarah; BLOCH, Renata Arruda de. (2005) "As Conferências Nacionais de Saúde na Construção do SUS". In: LIMA, Nísia Trinidade et al., (orgs.) Saúde e democracia: história e perspectivas do SUS. Rio de Janeiro, FIOCRUZ.

. (1998) Reviravolta na saúde: origem e articulação do movimento sanitário. Rio de Janeiro, FIOCRUZ.

FALLETI, Tulia G. (2010) "Inflitring the State: The Evolution of Health Care Reforms in Brazil, 1964-1988". In: MAHONEY, James; THELEN, Kathleen. Explaining Institutional Change: Ambiguity, Agency and Power. Cambridge, Cambridge University Press.

FEUERWERKER, Laura Camargo Macruz; et al. (2000) “O processo de construção e de trabalho da Rede UNIDA". Divulgação em Saúde para Debate, Londrina, PR, n.22, p.09-17.

FIGUEIREDO, Argelina Cheibub; LIMONGI, Fernando; VALENTE, Ana Luzia. (1999) "Governabilidade e concentração de poder institucional: o governo FHC". Tempo Social, São Paulo, n. 11 (2).

FIOCRUZ, (2006) “Toque da Redação”. Radis, 47, Rio de Janeiro.

FLEISCHER, David (2002) “As eleições municipais no Brasil: uma análise comparativa (1982-2000)”. Opinião Pública, Campinas, v.VIII, n.1, p.80-105.

FLEURY, Sônia, M. (1987) “O dilema reformista na reforma sanitária brasileira". Revista Administração Pública, Rio de Janeiro, 21 (4).

. (1988) “A análise necessária da reforma sanitária”. Saúde em debate, Rio de Janeiro, n. 22, oct., p. 25. CEBES.

(1989) "A questão democrática na saúde". In: Fleury, Sonia (org.) Saúde e Democracia: a luta do CEBES. São Paulo, Lemos Editorial. 
(1994) "Equidade e reforma sanitária: Brasil." Saúde em debate, Rio de Janeiro, n. 43, CEBES.

(Org.) (1997) Saúde e democracia: a luta do Cebes. São Paulo, Lemos.

FONSECA, Cristina M.O. (2006) A História da Abrasco: política, ensino e saúde no Brasil (20) In: LIMA, Nísia Trinidade; SANTANA, José Paranaguá. Saúde coletiva como compromisso: a trajetória da Abrasco. Rio de Janeiro, Editora Fiocruz.

FRANCO NETTO, Guilherme; ABREU, Regina (coords) (2009) Arouca, meu irmão. Uma trajetória a favor da Saúde Coletiva. Rio de Janeiro, Contra Capa.

FRSB - Fórum da Reforma Sanitária Brasileira. (2005) Manifesto do Fórum da Reforma Sanitária Brasileira: Reafirmando Compromissos pela Saúde dos Brasileiros. Brasília. Disponível em: <http://www.abrasco.org.br/publicacoes/arquivos/20060713121020.pdf>. Acesso em 20 de janeiro de 2012.

GALLO, Edmundo; NASCIMENTO, Paulo César. (1989) "Hegemonia, bloco histórico e movimento sanitário". In: FLEURY, Sonia (org.) Saúde e Democracia: a luta do CEBES. São Paulo, Lemos Editorial.

GAMSON, Willian A.; MEYER, David S. (2006) "Framing political opportunity". In: McADAM, Doug; McCARTHY, D. John; ZALD, N. Mayer. (Eds.) Comparative Perspectives on Social Movements. Political Opportunities, Mobilizing Structure, and Cultural Framings. Cambridge, Cambridge University Press.

GEORGE, Alexander L.; BENNETT, Andrew. (2005) "Process-tracing and historical explanation". In: GEORGE, Alexander L.; BENNETT, Andrew. Case studies and theory development in the social sciences. London, Cambridge.

GERRING, J. (2007). “Thinking about case studies" In: Case Study Research. Principles and Practices. Cambridge, Cambridge University Press.

GERSCHAM, Silvia. (2004) A democracia inconclusa: um estudo da Reforma Sanitária Brasileira. Rio de Janeiro, Fiocruz.

GOHN, Maria da Gloria. (2010) Movimentos sociais e redes de mobilizações civis no Brasil contemporâneo. Petrópolis, Editora Vozes.

(2006) Teoria dos movimentos sociais - paradigmas clássicos e contemporâneos. São Paulo, Edições Loyola.

GOLDSTONE, Jack A. (2003) "Introduction: bridging institutionalized and noninstitutionalized politics". In: GOLDSTONE, Jack A. States, parties and social movements. Cambridge, Cambridge University Press.

GOULART, Flávio A. (1996) Municipalização: Veredas. Caminhos do movimento municipalista de saúde no Brasil. Rio de Janeiro, Abrasco/Conasems. 
GUIGNI, Marco. (1999) "How social movements matter: past research, present problem, future development". In: GUIGNI, M.; McADAM, D; TILLY, Charles. (Eds.) How social movements matters. Minnesota, USA, University of Minnesota Press.

; PASSY, Florence. (1998) "Contentious Politics in Complex Societies: New Social Movements between Conflict and Cooperation" In: MARCO G. Giugni, McADAM, Doug; TILLY, Charles (Eds.). From Contention to Democracy. Lanham, MD, USA, Rowman \& Littlefield Publishers.

GURZA LAVALLE, Adrian. (2003) "Sem pena nem glória: o debate da sociedade civil nos anos 1990". Novos Estudos, São Paulo, n. 66, CEBRAP.

; CASTELLO, Graziela; BICHIR, Renata Mirandola. (2006) “Os bastidores da sociedade civil - protagonismos, redes e afinidades no seio das organizações civis". São Paulo, CEBRAP. Disponível em: <www.cebrap.org.br>. Acesso em 10 de maio de 2008 .

; ISUNZA, Ernesto. (2010). “Precisiones conceptuales para el debate contemporáneo sobre la innovación democrática - participación, controles sociales y representación". In: GURZA LAVALLE, Adrian; ISUNZA, E. La innovación democrática en América Latina: tramas y nudos de la representación, la participación y el control social. México: CIESAS - Universidad Veracruzana.

; HOUTZAGER, Peter; CASTELLO, Graziela (2011) "La construcción política de las sociedades civiles". In: GURZA LAVALLE, Adrian (Org.). El horizonte de la política. Brasil y la agenda contemporânea de investigación en el debate internacional. México, Ciesas, Publicaciones de la Casa Chata.

HAM, Christopher.; HILL, Michael. (1993) "Rumo à teoria da implementação" In: HAM, C.; HILL, M. O processo de elaboração de políticas no estado capitalista moderno. Londres, Harvest Wheatsheaf.

HJERN, Benny; PORTER, David O. (1981) "Implementation structure. A new unit of administrative analysis". In: HILL, Michael (org.). The policy process. A reader. Londres, Harvest Wheatsheaf.

HOCHSTETLER, Kathryn; KECK, Magaret, E. (2007) Greening Brasil. Environmental activism in state and society. London, Duke University.

HOGWOOD, Brian; GUNN, Lewis (1984) "Why 'perfect implementation' is unattainable". In: HILL, Michael (org.). The policy process. A reader. Londres, Harvest Wheatsheaf.

HOUTZAGER, Peter. (2004) "Além da sociedade civil e do Estado: autoridade política, instituições e mobilização popular". In: Peter P. Houtzager, Adrián Gurza. Os últimos cidadãos: conflito e modernização no Brasil rural (1964-1995). São Paulo, Globo. 
IMMERGUT, Ellen (1998). "The theoretical core of the new institicionalism" Politics \& Society, 26 (1). p. 5-34.

INFORMATIVO CNS - Informativo interativo eletrônico do CNS aos conselhos de Saúde, Brasília, n.12. Disponível em: <http://conselho.saude.gov.br/biblioteca/Informativo/12.pdf>. Acesso em 18 de dezembro de 2011.

JACOBI, Pedro Roberto. (1980). Resenha da Literatura Sobre Movimentos Sociais Urbanos No Brasil. Boletim Informativo e Bibliográfico de Ciências Sociais, São Paulo, p. 22-30.

(1987) “Movimentos Sociais Urbanos No Brasil: Reflexão Sobre A Literatura Nos Anos 70 e 80". BIB/ANPOCS, São Paulo, n.23, p.18-34.

. (1988) "Movimentos Sociais e Estado: Efeitos Político-Institucionais da Ação Coletiva”. Ciências Sociais Hoje, Caxambú, MG, Anuário da ANPOCS. p. 90-310.

(1993) Movimentos sociais e políticas públicas: demandas por saneamento básico e saúde - São Paulo, 1974 - 1984. São Paulo, Cortez. 2. ed.

JATENE, Adib D. (2011) Adib Jatene \& Alexandre Padilha: 40 anos de medicina: O que mudou? Campinas, São Paulo, Saberes Editora.

JASPER, James M.; GOODWIN, Jeff. (2009) The Social Movements Reader. USA, UK, Wiley-Blackwell.

KATZENSTEIN, Mary Fainsod. (1998) “Stepsisters: Feminist Movement Activism in Different Institutional Spaces," In: MEYER, David; TARROW, Sidney. (eds.) The Social Movement Society. Oxford, UK, Rowman and Littlefield Plubishers, INC.

KINGDON, John W. (1995) Agendas, Alternatives, and Public Policies. New York, Harper Collins College Publishers.

KINZO, Maria D’Alva G. (1988) Oposição e autoritarismo: Gênese e trajetória do MDB, 1966-79. São Paulo, Idesp/Vértice, 1988.

KNOKE, David (1994) "Networks of Elite Structure and Decision Making". In WASSERMAN, Stanley; GALASKIEWICZ, Joseph (Eds) Advances in Social Network Analysis. Research in the Social and Behavioral Sciences. Thousand Oaks, London, New Delhi, Sage Publication.

; PAPPI, Franz Urban. (1991). "Organizational action sets in the U.S. and German labor policy domain". American Sociological Review, Washington DC, n. 56, p. 509-523.

KUHN, Thomas, S. (2007) “A anomalia e a emergência das descobertas científicas" In: A estrutura das revoluções científicas. São Paulo, Editora Perspectiva. 
KWITKO, Marlow. (2003) "Nas brechas da crise: racionalizando a assistência médica previdenciária e fortalecendo o setor público - a construção do plano do Conasp". Divulgação em Saúde para Debate, Rio de Janeiro, n.28.

LABRA, Eliana; STRALEN, Cornelis Van; SCOCHI, Maria José. (1988) “A especialização em Saúde Púbica no Brasil no período 1982-1986". Estudos em Saúde Coletiva,Rio de Janeiro, n.5, Abrasco.

LAMOUNIER, Bolívar. (2005) Da independência a Lula: dois séculos de política brasileira. São Paulo: Augurium.

LIMA, Nísia Trinidade; FONSECA, Cristina M.O.; HOCHMAN, Gilberto. (2005) “A saúde na construção do Estado Nacional no Brasil: reforma sanitária em perspectiva histórica". In: LIMA, Nísia Trinidade et al., (Orgs.) Saúde e democracia: história e perspectivas do SUS. Rio de Janeiro, FIOCRUZ.

; SANTANA, José Paranaguá de. (2006) “Apresentação". In: LIMA, Nísia Trinidade; SANTANA, José Paranaguá (Orgs). Saúde coletiva como compromisso: a trajetória da Abrasco. Rio de Janeiro, Editora Fiocruz.

LIPSKY, Michael. (1980) Street-level bureaucracy: dilemmas of the individual in public services. Nova York, Russell Sage Foundation.

LUCCHESI, Geraldo. (1989) “Burocracia e política de saúde: arena ou ator". In: TEIXEIRA, Sonia Fleury (org.) Reforma Sanitária: em busca de uma teoria. São Paulo, Cortez; Rio de Janeiro, ABRASCO.

LUCHMANN, Lígia Helena Hahn. (2008) "Participação e representação nos conselhos gestores e no orçamento participativo". Caderno CRH [online], 21 (52), p. 87-97.

MACHADO, Francisco de Assis. (2010) O SUS que eu vivi - Parte 1: de clínico a sanitarista. Rio de Janeiro, Cebes.

MAHONEY, James. (2001) "Beyond Correlational Analysis: Recent Innovations in Theory and Methods". Sociological Forum, 16 (3). Disponível em: <http://www.jamesmahoney.org/articles/Beyond\%20Correlational\%20Analysis.pd $\mathrm{f}>$. Acesso em 25 de maio de 2010.

MANIFESTO da II Plenária Nacional dos Conselhos de Saúde, (2006) In: BRASIL/MS/CNS - Brasil. Ministério da Saúde. Conselho Nacional de Saúde. Plenárias nacionais de conselhos de saúde: resgate histórico do controle social no SUS. Brasília, Editora do Ministério da Saúde.

MANTEGA, Guido. (1997) “O governo Geisel, o II PND e os economistas.” Relatório de Pesquisa, São Paulo, n.3, EAESP/FGV/NPP. 
MARQUES, Eduardo Cesar. (2006) Redes sociais e poder no Estado brasileiro: aprendizados a partir de políticas urbanas. Revista Brasileira Ciência Sociais, São Paulo, v. 21, n. 60, fev.

MARQUES, Fernando Gonçalves. (2010) A Assembleia Nacional Constituinte e a política de saúde no Brasil. Dissertação de Mestrado (Programa de Ciência Política). Faculdade de Filosofia Letras e Ciências Humanas, Universidade de São Paulo, São Paulo.

MARSIGLIA, Regina Giffoni. (1993) “Funcionários públicos de saúde e organização de interesses". Cadernos RH Saúde, Brasília, 1 (3), Ministério da Saúde.

MARTES, Ana Cristina Braga Martes. (1990) O processo de institucionalização dos movimentos de reivindicação urbana - a participação popular e as Secretarias de Saúde em São Paulo, 1980 - 1990. Dissertação de Mestrado (Programa de Ciência Política). Faculdade de Filosofia Letras e Ciências Humanas, Universidade de São Paulo, São Paulo.

MARTINS, Ricardo C. de Rezende. (1991) “A pós-graduação no Brasil: uma análise do período 1970-90”. Educação Brasileira, Brasília, 13 (27), p. 93-119.

MAYNTZ, Renate. (2004) "Mechanisms in the Analysis of Social Macro-Phenomena". Philosophy of the Social Sciences, [online] 34, p. 237-259. Disponível em: http:// pos.sagepub.com

McADAM, Doug. (1982) Political Process and the Development of Black Insurgency, 1930-1970. Chicago, University of Chicago Press.

(2006) "Conceptual origins, current problems, future directions". In: McADAM, Doug; McCARTHY, D. John; ZALD, N. Mayer. (orgs.) Comparative Perspectives on Social Movements. Political Opportunities, Mobilizing Structure, and Cultural Framings. Cambridge, Cambridge University Press.

; SCOTT, W. Richard. (2005) “Organization and movements". In: DAVIS, Gerald F.; McADAM, Doug; SCOTT, Richard, W; ZALD, Mayer, N. (eds.) Social Movements and Organization Theory. New York, Cambridge University Press.

; TARROW, Sidney; TILLY, Charles. (2008) "Methods for Measuring Mechanisms of Contention". [online] Qualitative Sociology, 31 (4). Disponível em: < http://cps.sagepub.com/content/42/9/1143.abstract>. Acesso em 17 de janeiro de 2013.

McCARTHY, John D. (2006) “Constraints and opportunities in adopting, adapting, and inventing". In: McADAM, Doug; McCARTHY, D. John; ZALD, N. Mayer. (orgs.) Comparative Perspectives on Social Movements. Political Opportunities, Mobilizing Structure, and Cultural Framings. Cambridge, Cambridge University Press. 
; ZALD, Mayer N. (1977) "Resource Mobilization and Social Movements: A Partial Theory." American Journal of Sociology. 82, p.1212-1241 [online]. Disponível em < http:/ / www.jstor.org/ stable/2777934> Acesso em 12 de dezembro 2010.

MELO, Marcus André B. C. de. (1993) "Municipalismo, nation building e a modernização do Estado no Brasil". Revista Brasileira de Ciências Sociais, São Paulo, n.8 (23), p. 85-100, ANPOCS. Disponível em: <http://www.anpocs.org.br/portal/content/view/119/54/>. Acesso em 18 de novembro de 2011.

(2005) “O Sucesso Inesperado das Reformas de Segunda Geração: Federalismo, Reformas Constitucionais e Política Social". DADOS - Revista de Ciências Sociais, Rio de Janeiro, 48 (4), p. 845-889.

(2008) "Unexpected Successes, Unanticipated Failures: Social Policy from Cardoso to Lula". In: KINGSTONE, P.; POWER, T. (Eds.), Democratic Brazil Revisited. Pittsburgh, University of Pittsburgh Press.

MELUCCI, Alberto. (1996) "The process of collective identity". In: MELUCCI, Alberto. Challenging codes. Collective action in the information age. Cambridge, Cambridge University Press.

MENICUCCI, Telma. (2007) Público e Privado na Política de Assistência à Saúde no Brasil: atores, processos e trajetória. Rio de Janeiro, Fiocruz.

MERHY, Emerson Elias. (1991) “A lei orgânica da saúde é orgânica a quem?” Saúde em Debate, Rio de Janeiro, n. 32, CEBES.

MEYER, David S.; TARROW, Sidney. (1998) “A movement Society: Contentious Politics for a New Centuary". In: TARROW, Sidney.; MEYER David. S. (Ed.) The Social Movement Society: Contentious Politics for a New Century. Lanham, MD, USA, Rowman \& Littlefield.

MICHELS, Robert. ([1911] 1962). Political Parties: A Sociological Study of the Oligarchical Tendencies of Modern Democracy. New York: Collier Books.

MINOYO, Maria Cecília de Souza. (2006) “Atuação da Abrasco em Relação ao Ensino de Pós-Graduação na Área de Saúde Coletiva”. In: LIMA, Nísia Trinidade; SANTANA, José Paranaguá (Orgs). Saúde coletiva como compromisso: a trajetória da Abrasco. Rio de Janeiro, Editora Fiocruz.

MOÇÃO contra a privatização. (1977) Saúde em Debate, Rio de Janeiro, n.5, CEBES, out./nov./dez.

MOTTA, Rodrigo Patto Sá. (2007) “O MDB e as esquerdas”. In: FERREIRA, Jorge; REIS, Daniel Aarão (Orgs). As Esquerdas no Brasil: revolução e democracia, 3. Rio de Janeiro, Civilização Brasileira. 
NEDER, Carlos. (2001) Participação e gestão pública : a experiência dos movimentos populares de saúde no município de São Paulo. Dissertação de Mestrado (Programa de Pós-Graduação em Saúde Coletiva), Faculdade de Ciências Médicas, Universidade Estadual de Campinas, Campinas.

NEMES FILHO, Alexandre. (1992) Os médicos sanitaristas e a política de saúde no Estado de São Paulo no período de 1976 a 1988. Dissertação de Mestrado (Departamento de Prática de Saúde Pública), Faculdade de Saúde Pública, Universidade de São Paulo. São Paulo.

NEVES, Lúcia Maria Wanderley. (1994) Educação e política no Brasil de Hoje. São Paulo, Editora Cortez.

NITÃO, Samara. (2003) “Um encontro para não esquecer". Divulgação de Saúde para Debate, Rio de Janeiro, n. 28, ABRASCO.

NORONHA, Ana Beatriz de. (2002) "Graduação: é preciso mudar Transformações dependem de políticas de Educação e de Saúde". Radis - Comunicação em Saúde, Rio de Janeiro, n. 5.

NORONHA, José. C.; LEVCOVITZ, E.. (1994) “AIS-SUDS-SUS: os caminhos do direito à saúde". In: GUIMARÃES, R.; TAVARES, R. A. W. Saúde e sociedade no Brasil: anos 80. Rio de Janeiro, Relume-Dumará.

NUNES, Everardo Duarte. (1994a) "Saúde Coletiva: história de uma idéia e de um conceito". Saúde e Sociedade, São Paulo, 3(2), p. 5-21.

(1994b) “A Medicina social no Brasil: um estudo de sua trajetória”. In: CAMPO, Gastão Wagner de Souza; MERHY, Emerson Elias; NUNES, Everardo Duarte. Planejamento Sem Normas. São Paulo, Hucitec.

NUNES, Tânia Celeste Matos. (1998) A especialização em saúde pública e os serviços de saúde no Brasil. Tese de Doutorado (em Saúde Pública). Escola Nacional de Saúde Pública-ENSP, Fundação Oswaldo Cruz-Fiocruz, Rio de Janeiro.

OBSERVATÓRIO dos Técnicos em Saúde.(2006) Memória da Educação Professional em Saúde no Brasil Anos 1980-1990. Relatório Final. Laboratório de Trabalho e Educação Professional em Saúde (LATEPS) e Observatório dos Técnicos em Saúde (OTS), Rio de Janeiro.

OFFE, Claus. (1989) "A atribuição de status público a grupos de interesse". In: Capitalismo desorganizado. São Paulo, Editora Brasiliense.

OFÍCIO de encaminhamento de emenda popular da saúde. (1988) In: Saúde em Debate, Rio de Janeiro, 20 abr. CEBES.

OLIVEIRA, Jaime A. de Araújo. (1981) “Em defesa do Prev-saúde ou, VII Conferência Nacional de Saúde: Um passo adiante!". Saúde em Debate, Rio de Janeiro, 11, p.3846, CEBES. 
OLIVEIRA, Walter Ferreira de. (2009) “A Abrasme e o Congresso Brasileiro de Saúde mental como elementos de participação política e social em saúde mental. Caderno Brasileiro de Saúde Mental, 1(1), CD-Rom.

OLIVEIRA, Neilton A. at al. (2008) "Mudanças curriculares no ensino médico Brasileiro: Um debate crucial no contexto do Promed". Revista Brasileira de Educação Médica, Rio de Janeiro, 32 (3), p. 333 a 346.

OLIVER, E. Pamela; MYERS, Daniel J. (2003) “The coevolution of social movements". Mobilization: an international jornal, San Diego, California, USA, 8(1), p.1-24.

PAIM, Jairnilson. (1982) “Desenvolvimento teórico-conceitual do ensino em saúde coletiva". In: ABRASCO: Ensino da Saúde Pública, Medicina Preventiva e Social no Brasil. Rio de Janeiro, UFRJ, OPAS e Abrasco.

. (1984) “As políticas de saúde e a conjuntura atual”. Saúde em Debate, Rio de Janeiro, 15-16, p.8-15, CEBES.

(1997) "Bases conceituais da reforma sanitária brasileira". In: Fleury, Sonia (Org.) Saúde e Democracia: a luta do CEBES. São Paulo, Lemos Editorial.

(2008) Reforma Sanitária Brasileira: contribuição para a compreensão e crítica. Salvador/Rio de Janeiro, EDUFBA / FIOCRUZ.

PANDOLFI, Duce (1995). Camaradas e companheiros: história e memória do PCB. Rio de Janeiro, Relume-Dumará.

PAOLI, Maria Célia. (1995) “Movimentos sociais no Brasil: em busca de um estatuto político". In: HELLMANN, M. (Org) Movimentos Sociais e Democracia no Brasil. São Paulo, Marco Zero.

; TELLES, Vera da Silva. (2000) "Direitos Sociais. Conflitos e negociações no Brasil contemporâneo". In: ALVAREZ, Sonia E.; DAGNINO, Evelina; ESCOBAR, Arturo. Cultura e Política nos Movimentos Sociais Latino-Americanos. Novas Leituras. Belo Horizonte, Editora UFMG.

PATACHNIK, Eric. (2003) "After the public interest prevails: The political sustainability of policy reform". Governance, [online] 16 (2), p. 203-34. Disponível em: <http://www.wiley.com/WileyCDA/WileyTitle/productCd-GOVE.html>. Acessado em 12 de abril de 2012.

PAULA, Silvia Helena Bastos de; SANTOS, Rosa Maria Barros; BONFIM, José Ruben de Alcântara; MORAES, Maria Lima Salum. (2009) "A criação de Saúde em Debate, revista do Cebes: narrando a própria história". Saúde em Debate, Rio de Janeiro, 33 (81), p.140-147, CEBES.

PEDROSA, José Ivo dos Santos (2007) “Educação Popular no Ministério da Saúde: identificando espaços e referências". In: BRASIL/MS/SGEP/DAGEP - Brasil. Ministério da Saúde. Secretaria de Gestão Estratégica e Participativa. Departamento 
de Apoio à Gestão Participativa. Caderno de educação popular e saúde. Brasília, Ministério da Saúde.

PEREIRA, Carlos. (1996) “A Política Pública como Caixa de Pandora: Organização de Interesses, Processo Decisório e Efeitos Perversos na Reforma Sanitária Brasileira 1985-1989". Dados, Rio de Janeiro, n. 39 (3). Disponível em: <http://www.scielo.br/scielo.php?script=sci_arttext\&pid=S001152581996000300006 \&lng=en\&nrm=iso>. Acesso em 17 Setembro de 2012.

PEREIRA, Dejair José et al. (1991) "Projeto de Cooperação Técnica Pró-Organização dos Sistemas Municipais de Saúde”. Saúde em Debate, Rio de Janeiro, n. 33, p. 94-95, CEBES.

PIMENTA, Aparecida Linhares. (2006) "Bauru de 1986 a 1990". In: PIMENTA, Aparecida Linhares. Saúde de Amparo: a construção de espaços coletivos de gestão. Tese de Doutorado (Saúde Coletiva), Faculdade de Ciências Médicas, Universidade Estadual de Campinas, Campinas.

PIRES-ALVES, Fernando A. (2011). Cooperação interamericana em saúde na era do desenvolvimento: informação científica e tecnologias educacionais na formação de recursos humanos (1963-1983). Tese de Doutorado (Programa de Pós-Graduação em História das Ciências e da Saúde). Casa de Oswaldo Cruz - Fiocruz, Rio de Janeiro.

; PAIVA, Carlos Henrique Assunção. (2006) Recursos Críticos: história da cooperação técnica Opas-Brasil em recursos humanos para a saúde (1975-1988). Rio de Janeiro, Editora Fiocruz.

PND II. (1974) II Plano Nacional de Desenvolvimento, Brasília. Disponível em:<http://www.planalto.gov.br/ccivil_03/LEIS/1970-1979/anexo/ANL615174.PDF>. Acessado em 21 de outubro de 2011.

PORTA, Donatella Dela.; DIANI, Mario. (2006) “The study of social movements: recurring questions, (partially) changing answers" In: PORTA, Donatella Dela.; DIANI, Mario. Social Movement. An introduction. Oxford/Cambridge, Massachusetts, Blackwell.

POSSAS, Cristina de Albuquerque. (1980). Saúde, medicina e trabalho no Brasil: uma antropofagia do capitalismo selvagem. Dissertação de Mestrado (Departamento de Antropologia Social), Instituto de Filosofia e Ciências Humanas, Universidade Estadual de Campinas, Campinas.

QUEIROZ, Marcos de Souza; CASTRO, Maria Helena Guimarães; VIANA, Ana Luiza D'Ávila. (1993) A Organização dos serviços de saúde: uma avaliação da experiência de Campinas. Caderno de Pesquisa n 26. Campinas, Unicamp. www.nepp.unicamp.br/d.php?f=62 
RAGIN, Charles, C. (1992) "Introduction: cases of 'What is the case?' " In: RAGIN, Charles C.; BECKER, Howard S., What is a case? Exploring the foundations of social inquiry. Cambridge, Cambridge University Press.

RANGEL, Maria Ligia; VILASBÔAS, Ana Luiza. (1996) "Rede UNIDA: Breve histórico, concepção, organização e estratégias de ação". Divulgação em Saúde para Debate, Rio de Janeiro, n.12, CEBES.

REDEPOP - Rede de Educação Popular e Saúde. (2002) A Educação Popular em Saúde e o Governo Popular e Democrático do Partido dos Trabalhadores: considerações e propostas da Rede de Educação Popular e Saúde. (mimeo)

RELATÓRIO DA $1^{\text {a }}$ CONFERÊNCIA NACIONAL DE RECURSOS HUMANOS PARA A SAÚDE (1986) Relatório final. BRASIL: Ministério da Saúde - Secretaria Geral, Secretaria de Recursos Humanos. Disponível em <http:// bvsms.saude.gov.br/bvs/publicacoes/0116conf_rh.pdf,> acessado em 02 de abril de 2011.

RELATÓRIO da $8^{a}$ Conferência Nacional de Saúde (1986). Relatório final. Disponível

em:<http://conselho.saude.gov.br/biblioteca/Relatorios/relatorio_8.pdf> , acesso em 30 de março de 2010.

RELATÓRIO Sérgio Arouca 1967-1975 (2005a). Projeto Memória e Patrimônio da Saúde Pública no Brasil: A Trajetória de Sérgio Arouca. Rio de Janeiro. Disponível em:

<http://www.memoriasocial.pro.br/linhas/arouca/relatorios/relatorio19671975.pd $\mathrm{f}>$, acesso em 10 de novembro de 2011.

RELATÓRIO Sérgio Arouca 1976-1988 (2005b). Projeto Memória e Patrimônio da Saúde Pública no Brasil: A Trajetória de Sérgio Arouca. Rio de Janeiro. Disponível em:

http:/ / www.memoriasocial.pro.br/linhas/arouca/relatorios/relatorio19761988.pdf, acesso em 17 de setembro de 2012.

RELATÓRIO da Reunião da Plenária Nacional de Saúde, do dia 19 de março de 1992, Brasília (mimeo).

RODRIGUES NETO, Eleutério. (1997) “A via do parlamento" In: FLEURY, Sonia (org.) Saúde e democracia: a luta do CEBES. São Paulo, Lemos Editorial.

Fiocruz.

(2003) Saúde: promessas e limites da Constituição. Rio de Janeiro, Editora

ROMERO, Luiz Carlos. (2008) “O debate entre planejamento de recursos humanos para a saúde e autonomia universitária no parlamento brasileiro". Revista de Direito Sanitário. São Paulo, [online], 9 (3), p.75-88. Disponível em: < http:/ / www.revistasusp.sibi.usp.br/scielo.php?pid=S1516-

41792008000300004\&script=sci_abstract $>$. Acesso em 10 de setembro de 2010. 
ROSAS, Eric Jenner; CAMPOS, Francisco Eduardo. (1977) "Na IV SESAC Estudantes e profissionais (pela democratização da saúde)". Saúde em Debate. Rio de Janeiro, n. 4, p. 69-70, jul./ago./set. CEBES.

RUCHT, Dieter. (2004) "Movement allies, adversaries, and third parties". In: SNOW, David A.; SOULE Sarah A.; KRIESI, Hanspeter. The Blackwell Companion to social movements. USA, UK, Australia, Blackwell Publishing.

SABATIER, Paul A. (1986) "Top-down and bottom-up approaches to implementation research. In: HILL, Michael (org.). The policy process. A reader. Londres, Harvest Wheatsheaf.

; MAZMANIAN, Daniel. (1980) "The Implementation of Public Policy: A Framework for Analisys", Policy Studies Journal, California, USA, n. 8, p.538-560. Article first published online: 9 SEP 2005 | DOI: 10.1111/j.1541-0072.1980.tb01266.x

; WEIBLE, C. M. (2007) “The Advocacy Coalition Framework: innovations and clarifications". In: SABATIER, Paul. A. (Ed.) Theories of Policies Process. Boulder, Colorado, US. Westview Press.

SANTANA, José F.N. Paranaguá de. (1982) “Consideração sobre Pós-Graduação em Saúde Pública". In: ABRASCO, Ensino da Saúde Pública, Medicina Preventiva e Social no Brasil. Rio de Janeiro, UFRJ, OPAS e Abrasco.

SANTANA, José F.N. Paranaguá de. (2003) “Do amigo Eleutério". Divulgação em Saúde para Debate, Rio de Janeiro, n. 28, Abrasco.

SANTOS, Ana Lúcia Felix dos; AZEVEDO, Janete Maria Lins de. (2009) “A pósgraduação no Brasil, a pesquisa em educação e os estudos sobre a política educacional: os contornos da constituição de um campo acadêmico". Revista Brasileira de Educação, Rio de Janeiro, n. 14 (42).

SANTOS, Izabel dos. (2007) "Izabel dos Santos: fazendo história na história da enfermagem brasileira". Revista da Escola de Enfermagem da USP, São Paulo, n. 41(Esp.), p.853-8.

SANTOS, Nelson Rodrigues dos. (2008/2009) "Entrevista com Nelson Rodrigues dos Santos". Trabalho, Educação Saúde, Rio de Janeiro, n.6 (3), p.645-658. FIOCRUZ.

SCHMITTER, Phillippe C. (1992) "The Consolidation of democracy and representation of social groups". American Behavioral Scientist, University of Texas, USA, 35 (4/5).

SEVERO, Denise Osório; CUNHA, Alexandre Pareto; DA ROS, Marco Aurélio (2007) "Articulação nacional de movimentos e práticas de educação popular em saúde no estado de Santa Catarina: fortalezas e fragilidades". Texto contexto - enfermagem, Florianópolis, n. 16 (2), p. 239-45. 
SGP - Secretaria Geral da Presidência. (2006) Participação Social - Informativo Especial da SGP. Brasília, Secretária Geral da Presidência.

(2011) Conferências Nacionais Realizadas (1941-2010). Disponível em:<http://www.secretariageral.gov.br/.arquivos/arquivosnovos/CONFERENCIAS\%20NACIONAIS_Tabela_1941_\%202010_26abril2010.pdf> . Acesso em 13 fevereiro de 2011.

SILVA, Fabricio Pereira. (2005) Utopia Divida: crise e extinção do PCB (1979-1992). Dissertação de Mestrado (Programa de História Social). Instituto de Filosofia e Ciências Sociais, Universidade Federal do Rio de Janeiro, Rio de Janeiro.

SILVA, Marcelo Kunrath. (2010) "De volta aos movimentos sociais. Reflexões a partir da literatura brasileira recente". Ciências Sociais UNISINOS, Rio Grande do Sul, n. 46 (1), p. 2-9.

SIMPÓSIO sobre a Política Nacional de Saúde, 8a edição (2005) "Carta de Brasília", documento final do evento. Brasília. RADIS - Comunicação em Saúde, Rio de Janeiro, n.37, ENSP. Disponível em: <http://www.ensp.fiocruz.br/radis/revistaradis/37/pos_tudo/>. Acesso em 20 de janeiro de 2012.

SKOCPOL, Theda. (1985) "Bringing the State Back in: Strategies of Analysis in Current Research". In: EVANS, P.; RUESCHEMEYER, D.; SKOCPOL, T. Bringing the State Back In. Cambridge, Cambridge University Press.

(1995) Protecting Soldiers and Mothers: The political origins of Social policy in the United States. Cambridge, Harvard University Press.

(2008) "Bringing the State back in: retrospect and prospect. The 2007 Johan Skytte Prize Lecture". Scandinavian Political Studies, 31 (2), p. 109-124. WileyOnline Library.

SNOW, David A.; SOULE, Sarah A.; KRIESI, Hanspeter. (2007) "Introduction: Mapping the Terrain”. In: SNOW, David A.; SOULE, Sarah A.; KRIESI, Hanspeter. The Blackwell Companion to Social Movements. USA, UK, Australia, Blackwell Publishing.

STOTZ, Eduardo Navarro (2004) “Encontro de movimentos e práticas de Educação Popular e Saúde". Interface - Comunicação, Saúde, Educação, Botucatu, São Paulo, n. 8 (14), p.179-182.

; DAVID, Helena Maria Scherlowski Leal; WONG-UN, Júlio Alberto (2005) "Educação popular e saúde - trajetória, expressões e desafios de um movimento social". Revista de Atenção Primária à Saúde, Universidade Federal Juiz de Fora, Minas Gerais, 8(1), p.49-60.

TARROW, Sidney. (1998) "Introduction"; "Political opportunities and constraints"; "Struggling to reform". In: TARROW, Sidney. Power in movement. Social movements and contentious politics. Cambridge, Cambridge University Press. 
(2006) "States and opportunities: The political structuring of social movements". In: McADAM, Doug; McCARTHY, D. John; ZALD, N. Mayer. (orgs.) Comparative Perspectives on Social Movements. Political Opportunities, Mobilizing Structure, and Cultural Framings. Cambridge, Cambridge University Press.

(2010) "Dinamic of Diffusion: Mechanisms, Institutions, and Scale Shift". In: GIVAN, Rebecca Kolins; ROBERTS, Kenneth M.; SOULE, Sarah, A. The Diffusion of Social Movements. Actors, Mechanisms and Political Effects. Cambridge, Cambridge University Press.

(2011) "Global, conventional and Warring Movements and the Suppression of Contention: Themes in Contentious Politics Research". Política \& Sociedade, Universidade Federal de Santa Catarina, Santa Catarina, 10 (18).

TATAGIBA, Luciana. (2004) “A institucionalização da participação: os conselhos municipais de políticas públicas na cidade de São Paulo". In: AVRITZER, Leonardo. A participação em São Paulo, São Paulo, Unesp Editora.

. (2007) “Movimentos sociais e sistema político. Um diálogo (preliminar) com a literatura." Trabalho apresentado em $6^{\circ}$ Encontro da Associação Brasileira de Ciência Política, UNICAMP, Campinas.

TAYLOR, Verta; DYKE, Nella van. (2007) “Get up, Stand up": Tatical Repertories of Social Moviments" In: SNOW, David A.; SOULE, Sarah A.; KRIESI, Hanspeter. The Blackwell Companion to Social Movements. USA, UK, Australia, Blackwell Publishing.

TEIXEIRA, Sonia Maria Fleury. (1987) “O dilema reformista na reforma sanitária brasileira". Revista Administração Pública, Rio de Janeiro, 21 (4).

TELLES, Vera Silva. (1987) “Movimentos Sociais: reflexões sobre a experiência dos anos 70" In: SCHERER-WARREN, I. E KRISCHKE, P. J. (Orgs.) Uma revolução no cotidiano? Os novos movimentos sociais na América Latina. São Paulo, Brasiliense.

TEMPORÃO, José Gomes. (2003) “Ações Integradas de Saúde: no coração do sistema constituindo a contrapolítica". Divulgação em Saúde para Debate, Rio de Janeiro, n. 28, Abrasco.

TILLY, Charles; TARROW, Sidney (2007) Contentious politics. Boudler, Colorado, Paradigm Publisher.

TILLY, Charles. (1978) From mobilization to revolution. Reading, Massachusetts: Adisson-Wesley.

(1999). "Conclusion: From Interactions to Outcomes in Social Movement". In: GUIGNI, M; McADAM, D; TILLY, C. (Eds.) How social movements matters. Minnesota, University of Minnesota Press. 
Science, $4:$ 21-41.

(2004) "Social movements as Politics", "Inventions of the Social Movement" e "Future of Social Movements". In: TILLY, Charles Social Movements 1768-2004. Boudler, Colorado, Paradigm Publisher.

(2006) "Preface" e "Repertoire of contention". In: TILLY, Charles. Regime and Repertoire. Chicago, The University of Chicago Press.

UCHÔA, Helio Wanderley; PAIM, Elsa Ramos. (1982) “A experiência da ENSP na descentralização dos Cursos de Saúde Pública". In: Ensino da Saúde Pública, Medicina Preventiva e Social no Brasil. Rio de Janeiro, UFRJ, OPAS e Abrasco.

UGÁ, Maria Alicia D.; MARQUES, Rosa Maria. (2005) “O financiamento do SUS: trajetória, contexto e constrangimentos". In: LIMA, Nísia Trinidade et al., (Orgs.) Saúde e democracia: história e perspectivas do SUS. Rio de Janeiro, Editora Fiocruz.

VASCONCELOS, Eymard Mourão. (2004) “Educação Popular: de uma prática alternativa a uma estratégia de gestão participativa das políticas de saúde." Physis: Revista Saúde Coletiva, Rio de Janeiro, 14(1), p. 67-83.

(2007a) “Educação popular: instrumento de gestão participativa dos serviços de saúde". In: Brasil. Ministério da Saúde. Secretaria de Gestão Estratégica e Participativa. Departamento de Apoio à Gestão Participativa. Caderno de educação popular e saúde. Brasília, Ministério da Saúde.

(2007b) Apresentação no II Encontro Nacional dos Servidores que Atuam na Área de Educação em Saúde, promovido pela Fundação Nacional de Saúde (Funasa) de 11 a 14 de dezembro de 2007. Belo Horizonte. Disponível em <http:/ / www.gicessc.org/EymardMourao.html>. Acesso em 15 de junho de 2012.

VIANNA, Solon Magalhães. (1992). “A descentralização tutelada". Saúde em Debate. Rio de Janeiro, $\mathrm{n}^{\circ} 35$, julho.

WAMPLER, Brian. (2009) Participatory Budgeting in Brazil: Contestation, Cooperation, and Accountability. University Park, PA, Pennsylvania State University Press.

WEYLAND, Kurt. (1995) "Social movements and the State: the politics of health reform in Brazil". World Development, Nashville, Tennessee, USA. [online] Disponível em: < www.utexas.edu/cola/files/275345> Acessado em 15 de agosto 2012. 23(11).

WHITAKER, Francisco et al.. (1989) Cidadão Constituinte - a saga das emendas populares. Rio de Janeiro, Paz e Terra. 
WHITTIER, Nancy. (1997) "Political generations, micro-cohorts, and the transformation of social movements". American Sociological Review, Washington DC. $62(5)$.

ZALD, Mayer N. (2006) "Culture, ideology, and strategic framing". In: McADAM, Doug; McCARTHY, D. John; ZALD, N. Mayer. (Orgs.) Comparative Perspectives on Social Movements. Political Opportunities, Mobilizing Structure, and Cultural Framings. Cambridge, UK. Cambridge University Press.

\section{Entrevistas}

1. Conjunto de entrevistas do projeto "Constituição de Acervo sobre a Elaboração e Implementação das Políticas Prioritárias do Inamps: 1985-1988"

CORDEIRO, Hésio. (1987-1988) Entrevista in Coleção Políticas Prioritárias do Inamps (1985-1988). BR RJCOC 05-06-01-02-01. Fundação Oswaldo Cruz Casa de Oswaldo Cruz.

NOGUEIRA, Ricardo. (1987-1988) Entrevista in Coleção Políticas Prioritárias do Inamps (1985-1988). BR RJCOC 05-06-01-02-01. Fundação Oswaldo Cruz Casa de Oswaldo Cruz.

NORONHA, José Carvalho de.(1987-1988) Entrevista In Coleção Políticas Prioritárias do Inamps (1985-1988). BR RJCOC 05-06-01-02-01. Fundação Oswaldo Cruz Casa de Oswaldo Cruz.

RODRIGUEZ NETO, Eleutério. (1987-1988) Entrevista in Coleção Políticas Prioritárias do Inamps (1985-1988). BR RJCOC 05-06-01-02-01. Fundação Oswaldo Cruz Casa de Oswaldo Cruz.

TEMPORÃO, José Gomes. (1987-1988) Entrevista in Coleção Políticas Prioritárias do Inamps (1985-1988 BR RJCOC 05-06-01-02-01. Fundação Oswaldo Cruz - Casa de Oswaldo Cruz.

2. Conjunto de entrevistas do projeto "Reforma ou Contra Reforma? Histórias e Perspectivas do Sistema Único de Saúde no Brasil”. 
CORDEIRO, Hésio. (06 de julho de 2004) Depoimento. In: Reforma ou contrareforma? História e perspectivas do Sistema Único de Saúde no Brasil. Casa de Oswaldo Cruz, Departamento de Arquivo e Documentação, Série Programas e Projetos. Entrevista concedida a Flávio Coelho Edler e Dilene Raimundo Nascimento. Fitas1/6.

JOUVAL Junior Henri. (09 de janeiro de 2004) Depoimento. In: Reforma ou contrareforma? História e perspectivas do Sistema Único de Saúde no Brasil. Rio de Janeiro. Casa de Oswaldo Cruz, Departamento de Arquivo e Documentação Série Programas e Projetos.

NORONHA, José Carvalho. (10 de agosto de 2004 ) Depoimento. In:. Reforma ou contra-reforma? História e perspectivas do Sistema Único de Saúde no Brasil. Rio de Janeiro Casa de Oswaldo Cruz, Departamento de Arquivo e Documentação Série Programas e Projetos. Entrevista concedida a Flávio Coelho Edler e Dilene Raimundo Nascimento. Arquivo sonoro. Fitas1/7

3. Conjunto de entrevistas do "Projeto Memória e Patrimônio da Saúde Pública no Brasil: Trajetória de Sérgio Arouca"

BUSS, Paulo Marchiori. (26 de agosto de 2005) Discurso de Paulo Buss, na inauguração da estátua de Arouca na Fiocruz. In: Projeto Memória e Patrimônio da Saúde Pública no Brasil: Trajetória de Sérgio Arouca. Relatório de Atividades Sérgio Arouca. Rio de Janeiro.

CAMPOS, Francisco. (19 e 20 de maio de 2005) Depoimento. In: Projeto Memória e Patrimônio da Saúde Pública no Brasil: Trajetória de Sérgio Arouca. Relatório de Atividades Sérgio Arouca 1976-1988. Brasília. Entrevista concedida a Dr. Guilherme Franco Netto; Dra. Regina Abreu; Helena Rego Monteiro; Marcos, Pedro e Bruno.

CAMPOS, Gastão Wagner de Sousa. (29 de abril de 2005) Depoimento. In: Projeto Memória e Patrimônio da Saúde Pública no Brasil: Trajetória de Sérgio Arouca. Relatório de Atividades Sérgio Arouca 1967-1975. Campinas. Entrevista concedida Dr. Guilherme Franco Netto; Dra. Regina Abreu; Helena Rego Monteiro; Marcos, Pedro e Bruno.

FLEURY, Sônia. (14 e 15 de abril de 2005) Depoimento. In: Projeto Memória e Patrimônio da Saúde Pública no Brasil: Trajetória de Sérgio Arouca. Relatório de Atividades Sérgio Arouca 1976-1988. Rio de Janeiro. Entrevista concedida a: Dr. Guilherme Franco Netto; Dra. Regina Abreu; Helena Rego Monteiro; Marcos, Pedro e Bruno.

GADELHA, Paulo. (16 de abril de 2005) Depoimento. In: Projeto Memória e Patrimônio da Saúde Pública no Brasil: Trajetória de Sérgio Arouca. Relatório de Atividades Sérgio Arouca 1976-1988. Rio de Janeiro. 
GOES, Sérgio. (05 de outubro de 2005) Depoimento. In: Projeto Memória e Patrimônio da Saúde Pública no Brasil: Trajetória de Sérgio Arouca. Relatório de Atividades Sérgio Arouca 1976-1988. Rio de Janeiro. Entrevista concedida a: Dr. Guilherme Franco Netto; Dra. Regina Abreu; Helena Rego Monteiro; Marcos, Pedro e Bruno.

MIRANDA, Ary Carvalho de. (05 de outubro de 2005) Depoimento. In: Projeto Memória e Patrimônio da Saúde Pública no Brasil: Trajetória de Sérgio Arouca. Relatório de Atividades Sérgio Arouca 1976-1988. Rio de Janeiro. Entrevista concedida a: Dr. Guilherme Franco Netto; Dra. Regina Abreu; Helena Rego Monteiro; Marcos, Pedro e Bruno.

PELLEGRINI FILHO, Alberto Pellegrini. (05 de outubro de 2005) Depoimento. In: Projeto Memória e Patrimônio da Saúde Pública no Brasil: Trajetória de Sérgio Arouca. Relatório de Atividades Sérgio Arouca 1976-1988. Rio de Janeiro. Entrevista concedida a: Dr. Guilherme Franco Netto; Dra. Regina Abreu; Helena Rego Monteiro; Marcos, Pedro e Bruno.

RUBENS, José (2005). Entrevista in Memória e Patrimônio da Saúde Pública no Brasil: a Trajetória de Sérgio Arouca. Relatório de Atividades. Sergio Arouca 19671975. Rio de Janeiro.

SANTOS, Nelson R. (19 e 20 de maio de 2005) Depoimento. In: Projeto Memória e Patrimônio da Saúde Pública no Brasil: Trajetória de Sérgio Arouca. Relatório de Atividades Sérgio Arouca 1976-1988. Brasília. Entrevista concedida a: Dr. Guilherme Franco Netto; Dra. Regina Abreu; Helena Rego Monteiro; Marcos, Pedro e Bruno.

SILVA, Guilherme Rodrigues. (19 e 20 abril de 2005) Depoimento. In: Projeto Memória e Patrimônio da Saúde Pública no Brasil: Trajetória de Sérgio Arouca. Relatório de Atividades Sérgio Arouca 1967-1975. São Paulo. Entrevista concedida a: Dr. Guilherme Franco Netto; Dra. Regina Abreu; Helena Rego Monteiro; Marcos, Pedro e Bruno.

SOUZA, Arlindo Fábio Gómez de. (28 de junho de 2005) Depoimento. In: Projeto Memória e Patrimônio da Saúde Pública no Brasil: Trajetória de Sérgio Arouca. Relatório de Atividades Sérgio Arouca 1976-1988. Rio de Janeiro. Entrevista concedida a: Dr. Guilherme Franco Netto; Dra. Regina Abreu; Helena Rego Monteiro; Marcos, Pedro e Bruno.

TAVARES, Christina. (28 de junho de 2005) Depoimento. In: Projeto Memória e Patrimônio da Saúde Pública no Brasil: Trajetória de Sérgio Arouca. Relatório de Atividades Sérgio Arouca 1976-1988. Rio de Janeiro. Entrevista concedida a Dra. Regina Abreu.

TEMPORÃO, José Gomes. (14 e 15 de abril de 2005) Depoimento. In: Projeto Memória e Patrimônio da Saúde Pública no Brasil: Trajetória de Sérgio Arouca. Relatório de Atividades Sérgio Arouca 1976-1988. Rio de Janeiro. Entrevista concedida a: Dr. Guilherme Franco Netto; Dra. Regina Abreu; Helena Rego Monteiro; Marcos, Pedro e Bruno. 


\subsection{Entrevistas Coletivas}

ENTREVISTA Coletiva na casa de Ana Maria Testa Tambellini (12 de novembro de 2004). Entrevista in: Projeto Memória e Patrimônio da Saúde Pública no Brasil: Trajetória de Sérgio Arouca. Relatório de Atividades Sérgio Arouca 19761988. Projeto PRODOC 914 BRA 2000, Unesco. Entrevistada concedida à equipe do projeto: Dr. Guilherme Franco Netto; Dra. Regina Abreu; Helena Rego Monteiro; Marcos, Pedro e Bruno. Os entrevistados foram: Regina Abreu, Guilherme Franco Neto, Anamaria Testa Tambellini, Maria Luísa Testa Tambellini, Elizabeth Moreira dos Santos, Marília Bernardes Marques, Ary Carvalho de Miranda, Alberto Pellegrini Filho, Maria do Carmo Leal, Sérgio Góes de Paula, Maria Elide Bertoletto.

4. Conjunto de entrevistas do projeto "A construção do SUS. História da Reforma Sanitária e do Processo Participativo" .

ARAUJO, Adalgiza Balsemão. (11 de março de 2005) "Assistente Social": Depoimento. In: A construção do SUS. História da Reforma Sanitária e do Processo Participativo. Ministério da Saúde. 2006. Entrevista concedida a Luiz Carlos Fadel de Vasconcelos.

BARROS, Maria Elizabeth Diniz. (23 de fevereiro de 2005) "Socióloga": Depoimento. In: A construção do SUS. História da Reforma Sanitária e do Processo Participativo. Ministério da Saúde. 2006. Entrevista concedida a Luiz Carlos Fadel de Vasconcelos.

CAMPOS, Francisco Eduardo. (09 de novembro de 2005) "Médico": Depoimento. In: A construção do SUS. História da Reforma Sanitária e do Processo Participativo. Ministério da Saúde. 2006. Entrevista concedida a Luiz Carlos Fadel de Vasconcelos.

CRUZ, Elaine Aparecida. (24 de fevereiro de 2005) "Dirigente do Sindsaúde/SP": Depoimento. In: A construção do SUS. História da Reforma Sanitária e do Processo Participativo. Ministério da Saúde. 2006. Entrevista concedida a Luiz Carlos Fadel de Vasconcelos.

DODGE, Raquel Elias Ferreira. (24 de abril de 2005) "Advogada": Depoimento. In: A construção do SUS. História da Reforma Sanitária e do Processo Participativo. Ministério da Saúde. 2006. Entrevista concedida a Luiz Carlos Fadel de Vasconcelos.

DRUMMOND, Jocélio. (22 de junho de 2005) "Médico": Depoimento. In: A construção do SUS. História da Reforma Sanitária e do Processo Participativo. Ministério da Saúde. 2006. Entrevista concedida a Luiz Carlos Fadel de Vasconcelos. 
FEGHALI, Jandira. (24 de fevereiro de 2005) "Médica Especialista em Cardiologia Pediátrica": Depoimento. In: A construção do SUS. História da Reforma Sanitária e do Processo Participativo. Ministério da Saúde. 2006. Entrevista concedida a Luiz Carlos Fadel de Vasconcelos.

JAEGER, Maria Luiza. (25 de junho de 2005) "Socióloga": Depoimento. In: A construção do SUS. História da Reforma Sanitária e do Processo Participativo. Ministério da Saúde. 2006. Entrevista concedida a Luiz Carlos Fadel de Vasconcelos.

MACHADO, Francisco de Assis (Chicão). (02 de novembro de 2005) "Médico Sanitarista.": Depoimento. In: A construção do SUS. História da Reforma Sanitária e do Processo Participativo. Ministério da Saúde. 2006. Entrevista concedida a Luiz Carlos Fadel de Vasconcelos.

MEDEIROS, Humberto Jacques de. (07 de abril de 2005) "Advogado" : Depoimento. In: A construção do SUS. História da Reforma Sanitária e do Processo Participativo. Ministério da Saúde. 2006. Entrevista concedida a Luiz Carlos Fadel de Vasconcelos.

NUNES, Fabíola de Aguiar. (29 de Abril de 2005) "Médica Sanitarista": Depoimento. In: A construção do SUS. História da Reforma Sanitária e do Processo Participativo. Ministério da Saúde. 2006. Entrevista concedida a Luiz Carlos Fadel de Vasconcelos.

O'DYER, Gilson Cantarino. (26 de novembro de 2005) "Médico especialista em psiquiatria geral e infantil": Depoimento. In: A construção do SUS. História da Reforma Sanitária e do Processo Participativo. Ministério da Saúde. 2006. Entrevista concedida a Luiz Carlos Fadel de Vasconcelos.

SANTOS, Maria do Espírito Santo Tavares. (Santinha). (21 de março de 2005) "Médica Sanitarista": Depoimento. In: A construção do SUS. História da Reforma Sanitária e do Processo Participativo. Ministério da Saúde. 2006. Entrevista concedida a Luiz Carlos Fadel de Vasconcelos.

SANTOS, Nelson Rodrigues. (Nelsão). (09 de março de 2005) "Médico Sanitarista": Depoimento. In: A construção do SUS. História da Reforma Sanitária e do Processo Participativo. Ministério da Saúde. 2006. Entrevista concedida a Luiz Carlos Fadel de Vasconcelos.

SILVA, Jacinta de Fátima Senna. (11 de março de 2005) "Enfermeira Sanitarista": Depoimento. In: A construção do SUS. História da Reforma Sanitária e do Processo Participativo. Ministério da Saúde. 2006. Entrevista concedida a Luiz Carlos Fadel de Vasconcelos.

SILVEIRA NETO, Crescêncio Antunes. (24 de fevereiro de 2005) "Médico Hematologia Clínica": Depoimento. In: A construção do SUS. História da Reforma Sanitária e do Processo Participativo. Ministério da Saúde. 2006. Entrevista concedida a Luiz Carlos Fadel de Vasconcelos. 
SOUZA, Arlindo Fábio Gomez. (16 de março de 2005) "Sociólogo Sanitarista": Depoimento. In: A construção do SUS. História da Reforma Sanitária e do Processo Participativo. Ministério da Saúde. 2006. Entrevista concedida a Luiz Carlos Fadel de Vasconcelos.

5. Entrevista do projeto "História da Cooperação Técnica em Recursos Humanos no Brasil".

SANTANA, José Francisco Paranaguá de. (21 e 22 de fevereiro de 2005) Depoimento. In: História da Cooperação Técnica em Recursos Humanos no Brasil. Rio de Janeiro. Rede de Observatório em Recursos Humanos em Saúde do Brasil. Observatório História e Saúde. Casa de Oswaldo Cruz. Fiocruz. Disponível em: <http://observatoriohistoria.coc.fiocruz.br/php/level.php?lang=pt\&component=43 \&item=4> . Acesso em: 17 de agosto de 2012.

6. Conjunto de entrevistas realizadas para a presente tese

BARROS, Elisabeth (03 de dezembro de 2009) "Sanitarista": Entrevista para esta tese. Entrevista concedida para Monika Dowbor .

CARVALHO, Gilson (15 de maio de 2012) Sanitarista": Entrevista para esta tese. Entrevista concedida a Monika Dowbor por Skype.

DUARTE, José Enio Servilha (28 de maio de 2012) "Sanitarista": Entrevista para esta tese. Entrevista concedida para Monika Dowbor.

FEUERWERKER, Laura (14 de setembro de 2012) "Sanitarista": Entrevista para esta tese. Entrevista concedida a Monika Dowbor por Skype.

GOULART, Flavio (8 de maio de 2012) "Sanitarista": Entrevista para esta tese. Entrevista concedida a Monika Dowbor por Skype.

MEDEIROS, José Eri Osório de (24 de maio de 2012) "Sanitarista": Entrevista para esta tese. Entrevista concedida a Monika Dowbor por Skype.

PIOLA, Sergio (05 de março de 2012) "Sanitarista": Entrevista para esta tese. Entrevista concedida a Monika Dowbor por Skype.

SILVA, Jacinta de Fátima Senna da (03 de dezembro de 2009) Sanitarista": Entrevista para esta tese. Entrevista concedida para Monika Dowbor .

VASCONCELOS, Eymard. (27 de janeiro de 2012) "Sanitarista": Entrevista para esta tese. Entrevista concedida a Monika Dowbor por telefone. 
7. Outras entrevistas

ALMEIDA, Márcio José de. (2001) Entrevista. In: Olho Mágico 8 (2), http:/ / www.ccs.uel.br/olhomagico/v8n2/index.html

ALMEIDA, Márcio José de. (2001) entrevista In: Observatório RH NESC/UFRN. http://www.observatorio.nesc.ufrn.br/entrevista_10.htm

\section{Vídeos}

SEMINÁRIO SAÚDE E DEMOCRACIA (2008) Produção de CEBES - Centro Brasileiro de Estudos de Saúde. Rio de Janeiro. Suporte digital online disponível em: <http:/ / www.cebes.org.br/internaEditoria.asp?idConteudo=122\&idSubCategoria=3 7>, acesso em 18 de janeiro de 2011.

TRABALHO E FORMAÇÃO EM SAÚDE: A Trajetória de Izabel dos Santos (2010) Produção do Brasil - Ministério da Saúde; OPAS; FUNDEP. Suporte Digital online, disponível em <http:/ / youtube.googleapis.com/v/OUgK4NK8zGk?fs=1 